\title{
Daniel Abbate
}

\section{Estudo Filogenético da subfamília Nassariinae (Neogastropoda, Buccinoidea, Nassariidae).}

São Paulo

2016

Daniel Abbate 
Estudo Filogenético da subfamília Nassariinae (Neogastropoda, Buccinoidea, Nassariidae).

Phylogenetic study of the subfamily Nassariinae Neogastropoda, Buccinoidea, Nassariidae).

Tese apresentada ao Instituto de Biociências da Universidade de São Paulo para a obtenção do título de Doutor em Ciências, área de Zoologia.

Orientador: $\operatorname{Prof}^{\mathrm{o}} \mathrm{Dr}^{\mathrm{o}}$ Luiz Ricardo de Simone

São Paulo

2016 


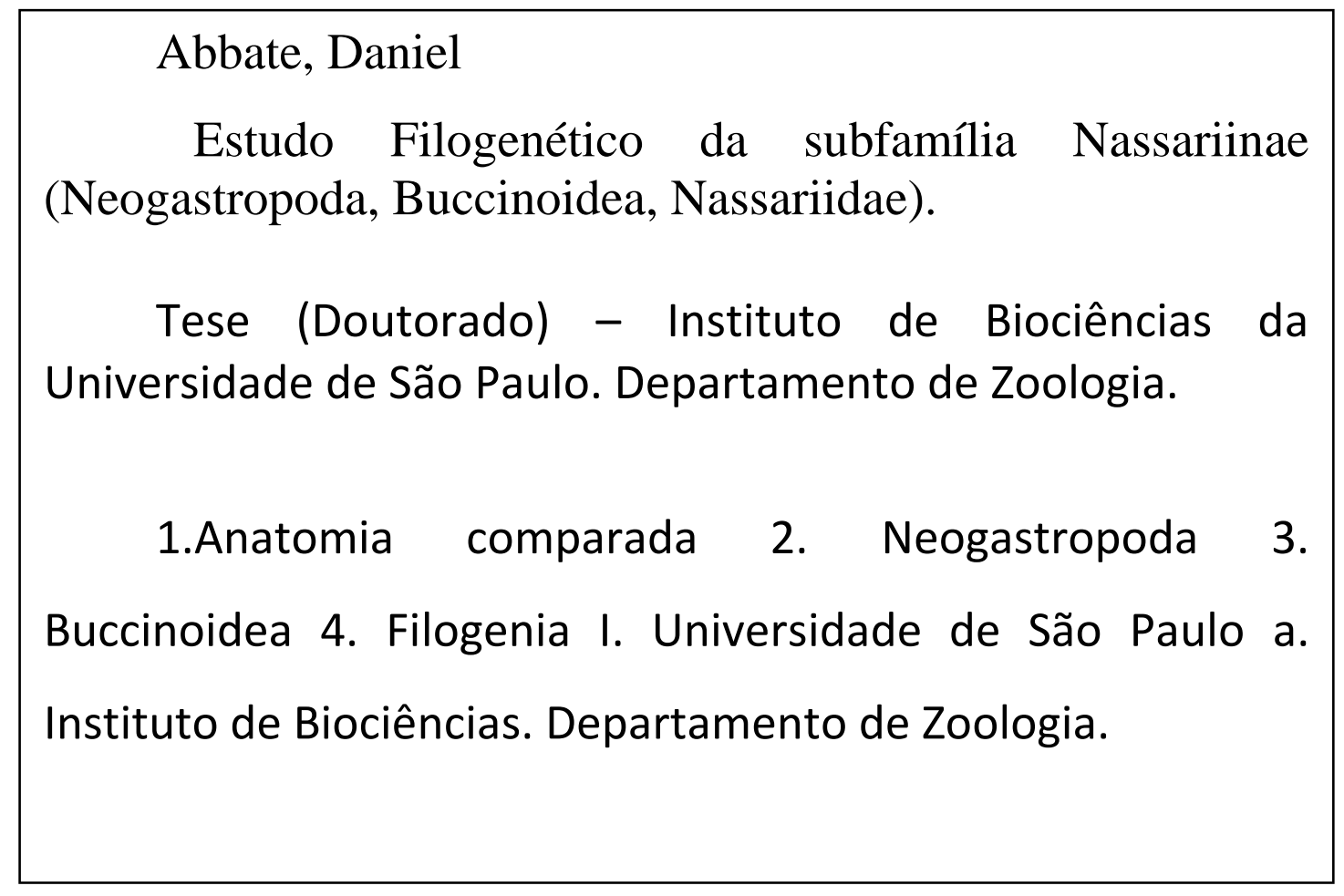

Comissão Julgadora:

Prof. Dr.

Prof. Dr.

Prof. Dr.

Prof. Dr.

Prof. Dr. Luiz Ricardo Lopes de Simone

Orientador 


\section{Agradecimentos}

Agradeço ao meu orientador Luiz Ricardo Lopes de Simone, pela oportunidade, dedicação e confiança depositadas em mim, seus ensinamentos me serviram como exemplo tanto em cunho profissional como pessoal, sua dedicação, honestidade e caráter será um modelo que adotarei pelo resto de minha vida.

Ao CNPq que fomentou essa pesquisa e que me apóia desde a iniciação cientifica.

A minha companheira, amiga e colega de profissão, minha amada esposa, Patricia Oristanio.

A minha amada família que sempre me apoiou e acreditou em minha dedicação.

A todas instituições que me enviaram material, a todos os professores que fizeram parte de minha formação, aos meus colegas de laboratório e ao corpo técnico envolvido durante essa jornada.

Aos animais estudados que sacrificaram suas vidas em prol da Ciência.

MUITO OBRIGADO! 


\section{Sumário}

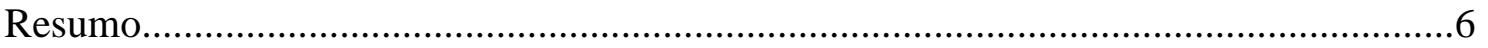

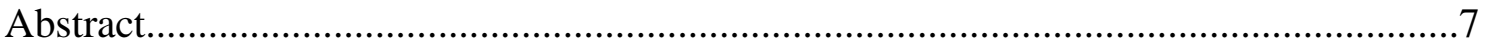

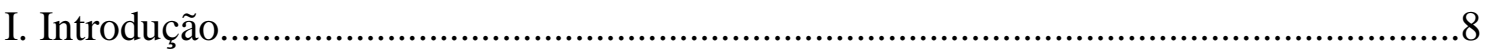

1. O conhecimento atual acerca dos Nassarídeos.......................................................8

2. Caracterização da família Nassariidae................................................................

3. Estudos filogenéticos e a utilização de dados morfológicos e moleculares...............11

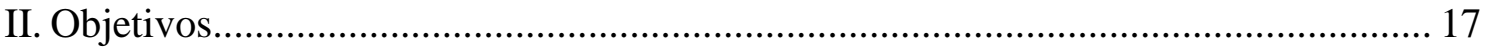

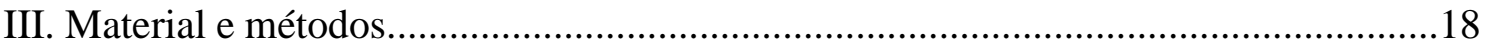

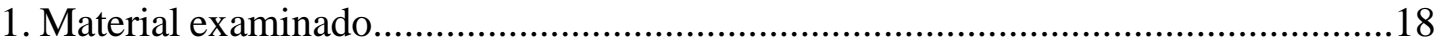

2. Terminologia adotada, dissecções e ilustrações....................................................20

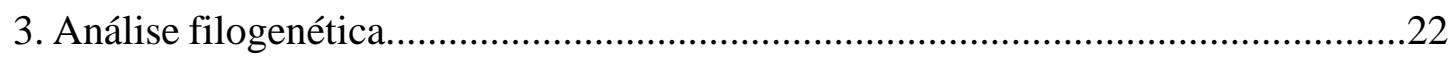

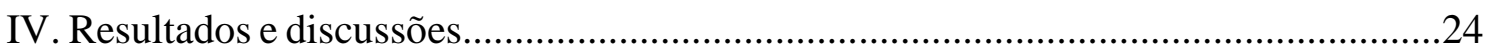

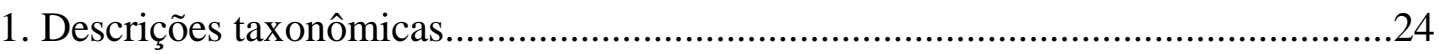

2. Apresentação e discussão dos caracteres...........................................................177

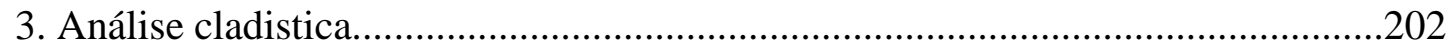

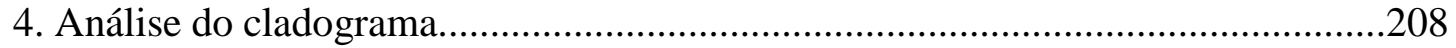

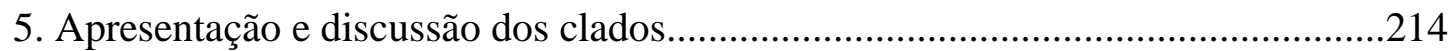

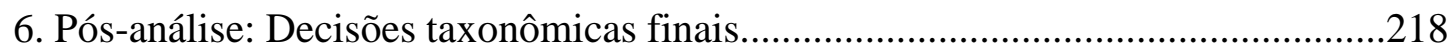

7. Resumo da taxonomia proposta para Nassariidae...............................................220

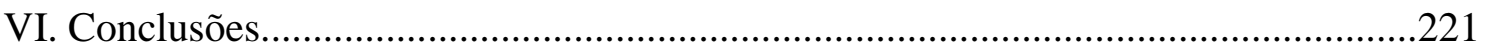

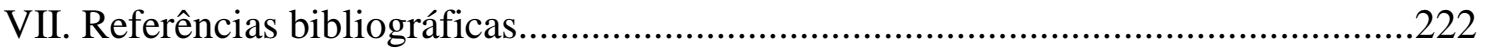

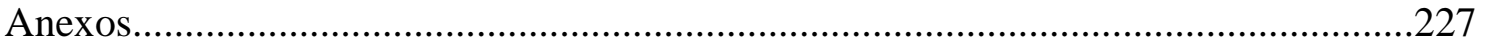




\section{Resumo}

A família Nassariidae é um grupo de caracóis detritívoros marinhos que habitam fundos de substratos incosolidados e, em menor medida, costões rochosos. A família pertence a superfamília Buccinoidea e é considerada proximamente relacionada a família Buccinidae. É considerado um táxon monofilético e apresenta as seguintes sinapomorfias: tentáculos cefálicos duas vezes maiores que a cabeça, presença de tentáculos epipodiais, dente radular raquidiano multicuspidado e ausência de bursa copulatrix no oviduto palial das fêmeas. De acordo com as últimas sugestões de classificações filogenéticas, o arranjo interno de Nassariidae ainda não atingiu um consenso e o número de subfamílias ainda não é certo. O presente trabalho apresenta um estudo morfológico detalhado de alguns representantes de Buccinoidea e Nassariidae visando testar a monofilia deste clado, bem como elucidar o posicionamento filogenético dos gêneros de cada família do clado. Todos os gêneros de Nassariidae estão representados, e estão representados, em sua maioria, pela espécie-tipo, totalizam um grupo interno representado por 24 espécies. O grupo externo está representado por outros Buccinoidea e um Pseudolividae (Benthobia atafona), considerado para o enraizamento, totalizando 13 espécies. Foi realizada uma análise cladística, com buscas heurísticas com pesos iguais para cada caráter e uma pesagem diferencial, específica determinada pela constante $(\mathrm{K})$. O resultado da análise confirmou a monofilia de Nassariidae, entretanto confirmou a monofilia de apenas duas subfamílias: Nassariinae e Buccinanopsinae. Alguns sistemas foram analisados com mais precisão e mostraram-se potencialmente informativos, principalmente para táxons mais específicos.

Palavras-chave: Nassariidae, sistemática, morfologia, filogenia. 


\section{Abstract}

The Nassariidae family is a group of detritivores marine snails that inhabit sands substrates and intertidal zone. The family belongs to the superfamily Buccinoidea and is considered closely related to Buccinidae family. It is considered a monophyletic taxon and has the following synapomorphies: cephalic tentacles twice larger than the head, presence of epipodiais tentacles, central radular tooth multicuspidated and no bursa copulatrix in palial oviduct of females. According to the latest suggestions of phylogenetic classification, the Nassariidae internal arrangement has not yet reached a consensus and the number of subfamilies is still not exact. This paper presents a detailed morphological study of some representatives of Buccinoidea and Nassariidae to test the monophyly of this clade and elucidate the phylogenetic position of the genera of each family clade. All Nassariidae genres are represented, and are represented mostly by the type species, totaling an internal group represented by 24 species. The out group is represented by other Buccinoidea and one Pseudolividae (Benthobia atafona), considered for rooting, totaling 13 species. A cladistic analysis with heuristic searches with equal weights for each character and a differential weighing, determined by specific constant (K) was performed. The result of the analysis confirmed the monophyly of Nassariidae, however confirmed the monophyly only two subfamilies: Nassariinae and Buccinanopsinae. Some systems were analyzed more accurately and shown to be potentially informative, especially for more specific taxa.

Keywords: Nassariidae, systematics, morphology, phylogeny. 


\section{Introducão}

\section{O conhecimento taxonômico atual acerca dos}

\section{Nassarídeos}

A família Nassariidae pertence a superfamília Buccinoidea e é considerada proximamente relacionada a família Buccinidae (Hayashi, 2005). Os caracteres presentes na concha (protoconcha e teleoconcha), opérculo, rádula e tentáculos epipodiais presentes na borda posterior do pé, vem sendo usados na taxonomia em nível de subfamílias e gêneros (Cernohorsky, 1984; Shuto, 1969), porém diferentes classificações divergem quanto ao número de subfamílias existentes para a família. Cernohorsky (1984) e Shuto (1969) enumeram três subfamílias; Cylleninae, Nassariinae e Dorsaniinae. A configuração com quatro subfamílias, somando-se Bullinae, as três anteriores, foi adotada por Allmon (1990), Simone \& Pastorino (2014) e Kantor \& Kilburn (2001). No entanto, esse número ainda oscila e subfamílias como Buccinanopsinae (Galindo et al., 2016) e Photinae (Rosenberg, 2014) foram recentemente incluídas à família.

As afinidades dos nassarídeos com diversas outras famílias e gêneros da superfamília Buccinoidea são discutidas por diversos autores (Bandel, 1984; Cernohorsky, 1984; Haasl, 2000; Kantor, 2003; Kantor \& Kilburn, 2001), que, em geral, sugerem que os limites das barreiras que os separam ou os unem necessita de uma revisão mais aprofundada. Em particular, a reinclusão dos gêneros Engoniophos, Woodring, 1928; Antillophos, Woodring, 1928 e Phos, Monfort, 1810, atualmente bucinídeos, na família Nassariidae (Landal et al., 2013; Vokes, 1969).

Em uma tentativa de corroborar com essa hipótese taxonômica Haasl (2000), realizou um estudo filogenético morfológico e incluiu a subfamília Photinae em Nassariidae. Kantor \& Kilburn (2001) e Kantor (2003) também questionaram a posição taxonômica de alguns gêneros tradicionalmente locados na família Buccinidae, e.g., Busycon Röding, 1798; Nassodonta H. Adams, 1867 e Nassaria Link, 1807.

Esse conflito taxonômico se estende para o nível de gêneros e se agrava ainda mais no nível de espécies, tomando como exemplo as espécies contidas no gênero Buccinanops d'Orbigny, 1841, conseguimos ver que essas espécies são rearranjadas em diferentes gêneros ao longo de suas histórias taxonômicas (Simone \& Pastorino, 2014). Os dois gêneros comumente mais usados, nesses casos, são Dorsanum Gray, 1847 e Bullia Gray, 1834 que também apresentam dúvidas taxonômicas entre si, uma vez que 
Adam \& Knudsen (1984) considerou Dorsanum sinônimo júnior de Bullia e Allmon (1990) considerou Dorsanum válido, porém, apenas restrito a espécie tipo Dorsanum miran Bruguière, 1789 e, ainda, numa subfamília própria.

A fraca e aparentemente continua variação nos caracteres conquiliológicos em Nassariidae resulta em uma taxonomia "intimidante", com complexas listas sinonímicas e cerca de 2500 espécies nominais (1320 existentes e 1180 fósseis) (Cernohorsky, 1984). Cerca de apenas 60 espécies são classificadas em outros gêneros, que não Nassarius Duméril, 1805 (Galindo et al. 2016), e são locados em outros gêneros da família, o que mostra o quão homogêneo é o grupo.

A subfamília Nassariinae, alvo principal do presente estudo, apresenta duas principais divergências taxonômicas para o oceano Atlântico Ocidental. Uma delas é a relação entre Nassarius vibex (Say, 1822) e Nassarius polygonatus (Lamarck, 1822). Embora Kaicher (1973) tenha confirmado essas duas espécies como distintas, sendo a primeira com distribuição para Flórida e Caribe e a segunda para o Brasil, anatomicamente as espécies se mostraram muito semelhantes e possivelmente possam ser consideradas sinônimos. A segunda é a separação do complexo de espécies "Nassarius" albus (Say, 1826) em possíveis diferentes espécies, atualmente esse complexo apresenta ampla distribuição desde a Flórida até o sul do Brasil, mesmo apresentando morfotipos conquiliológicos diferentes entre si.

\section{Caracterização da família Nassariidae}

A família Nassariidae é um grupo de caracóis detritívoros exclusivamente marinhos que habitam fundos de substratos incosolidados e, em menor medida, costões rochosos, sua distribuição batimétrica abrange a zona entre marés até águas profundas, 01000 m, porém, com maior abundância entre 0 e 300 m e com maior diversidade em águas tropicais (Nekhaev, 2014). Sua ecologia, toxicologia e paleontologia é assunto em diversos estudos (e.g. Lahbib et al., 2010; Gili \& Martinell, 1994, 2000). Na Ásia algumas espécies de nassarídeos são consumidas como alimento e, por conta disso, torna-se problema de saúde pública devido a capacidade dessas espécies de acumular e produzir toxinas (Zou et al., 2012).

As espécies da família são caracterizadas por serem pequenas a médias (4-75 $\mathrm{mm}$ ), com espira da concha alta, forma oval e com presença ou não de ombro na abertura (Harasewych, 1998). A superfície da concha pode ser lisa ou apresentar esculturas axiais 
e espirais. As esculturas axiais, geralmente, consistem em costelas bem definidas restritas a porção posterior das voltas (Cernohorsky, 1984).

A abertura da concha é, em sua maioria, oval e apresenta um lábio externo grosso com presença de esculturas. A columela, comumente, nas espécies pertencentes a família é curta e torcida e geralmente apresenta um dente parietal que delimita o canal anal, o que pode ser considerado diagnóstico para a família (Nuttall \& Cooper, 1973). Todos os Nassariidae apresentam um calo parietal, ora pequeno restrito à abertura, ora amplo chegando a cobrir toda a volta corporal, formando assim, o escudo parietal (Harasewych, 1998).

A coloração da concha abrange várias tonalidades e são encontrados nassarídeos brancos até com coloração bem escuras, por exemplo, cinza. Quando presente o perióstraco apresenta coloração amarelada a bege. O opérculo apresenta características comuns a ordem Neogastropoda, sendo córneo e com núcleo terminal, porém a presença de expansões serrilhadas em sua lateral também pode ser considerada diagnóstica para a família (Cernohorsky, 1984).

Em relação a anatomia, assim como nas famílias Buccinidae, Melongenidae e Fasciolariidae, as glândulas anal e salivares acessória são ausentes (Ponder, 1973a). Os nassarídeos são usualmente distinguidos dos bucinídeos pela conformação dos dentes radulares, e a presença de tentáculos epipodiais na margem posterior do pé (Harasewych, 1998).

Os nassarídeos são dioicos com fertilização interna, a morfologia das capsulas dos ovos varia bastante em forma, mas sempre estão fixadas ao substrato, cada capsula pode conter cerca de 2500 ovos (D’Asaro, 1993). O desenvolvimento, comumente, é planctônico, permanecendo dias ou até meses na coluna d'água (Cather, 1973). Pseudohermafroditismo causado por contaminação do ambiente marinho pelo agente desincrustante TBT- Tributil-Estanho (Imposex), que é o aparecimento de um pênis, não funcional, em fêmeas nas primeiras fases do desenvolvimento (Jenner, 1979). Esse fenômeno já foi relatado para determinadas populações de Nassarius reticulatus (Linné, 1758) (Bryan et al., 2009).

Nassariidae é a mais “jovem” família incluída na superfamília Buccinoidea, com espécies atribuídas a subfamília Dorsaninae, datando do Paleoceno, enquanto as espécies atribuídas a Cylleninae e Nassariinae possuem seu primeiro registro datadas para o Mioceno (Cernohorsky, 1984). 


\section{Estudos Filogenéticos e a utilização de dados morfológicos e moleculares}

A Filogenia dos gastrópodes vem recebido relativa atenção a partir de meados do século passado (e.g., Graham, 1985; Haszprunar, 1988a; Ponder \& Lindberg, 1995; Bieler, 1992). Teorias sobre sua evolução vem sendo formadas juntamente com uma crescente consciência da necessidade de hipóteses filogenéticas na construção de cenários evolutivos, porém, estas ideias requerem uma rigorosa análise de dados (Ponder \& Lindberg, 1995).

As primeiras especulações sobre as relações dos gastrópodes eram baseadas apenas em um único sistema ou estrutura, por exemplo, Troschel (1893) sobre rádulas e Bouvier (1887) discorrendo sobre sistema nervoso central. Uma visão mais holística e completa sobre a morfologia total do animal em busca de caracteres que auxiliem na classificação se iniciou com Thiele (1929) trazendo uma nova síntese e refinamento para as classificações anteriores. Ele construiu e modificou o conceito anterior de MilneEdwards (1848) de três subclasses; Prosobranchia, Opistobranchia e Pulmonata. A nova notável contribuição sobre esse conceito foi a divisão da subclasse Prosobranchia em três ordens, a mais plesiomórfica Archeogastropoda; a intermediaria Mesogastropoda e a mais apomórfica Stenoglossa (=Neogastropoda, Wenz, 1938).

O arranjo dos prosobrânquios em uma série linear (Archeogastropoda, Mesogastropoda e Neogastropoda) foi modificada por Ponder (1973) que argumenta que os neogastrópodes derivam dos arqueogastrópodes ou de possíveis mesogastrópodes basais. No entanto, a maior alteração na classificação de Thiele foi realizada por Golikov \& Starobogatov (1975), que embora mantiveram as ordens Opistobranchia e Pulmonata, recriaram um táxon hierarquicamente maior denominado Cyclobranchia, que distingue Docoglossa e Patellogastropoda dos demais gastrópodes.

Os estudos sobre Neogastropoda, aprofundaram-se com Haszprunar (1988) e Ponder \& Lindberg (1997), ambos baseados em caracteres morfológicos. Haszprunar confirma a monofilia da ordem, mas sugere que a definição do possível ancestral e suas 


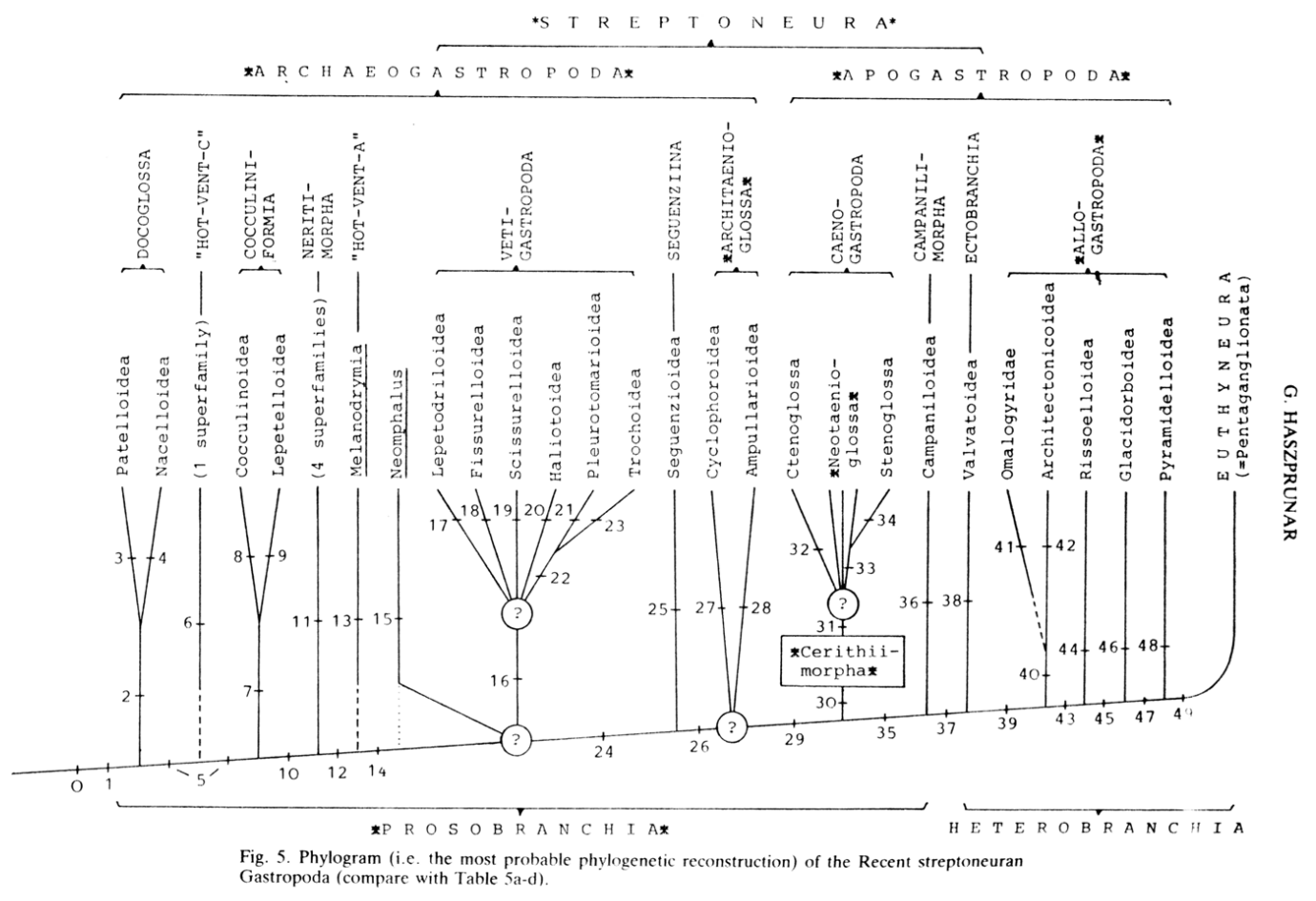

Fig. 1- Cladograma extraído de Haszprunar (1988) onde ilustra a complexidade das relações da ordem Stenoglossa = Neogastropoda, nó 33 .

Diversos autores até meados da década de 60 aceitavam que o grupo irmão dos neogastrópodes seria os "mesogastrópodes superiores", por exemplo a superfamília Tonnoidea, com base nas similaridades encontradas na rádula e no aparato bucal, especialmente na proboscide. Haszprunar (1988) diverge dessa hipótese e corrobora com Ponder (1973) (Fig. 2), ao dizer que a alta especialização celular do osfrádio é um indicio, mais confiável, que a origem dos neogastrópodes está diretamente relacionada aos Archeogastropoda ou "mesogastrópodes inferiores".

Em sua mega filogenia de Caenogastropoda, Simone (2011) volta a confrontar Ponder (1973) e Haszprunar (1988) e sugere, novamente, que o grupo irmão da ordem Neogastropoda é, de fato, a superfamília Tonnoidea (Fig. 3), essa hipótese é sustentada por 18 caracteres morfológicos fundados no opérculo, brânquias, tecido renal, rádulas, sistema digestivo anterior e genitais, táxon denominado Hypsogastropoda.

A superfamília Buccinoidea (sensu Thiele, 1928 e parte de Muricoidea 1.s. compreende a mais diversificada porção da radiação dos Muricoidea que aconteceu durante o Cretáceo e Cenozoico (Haasl, 2000). 


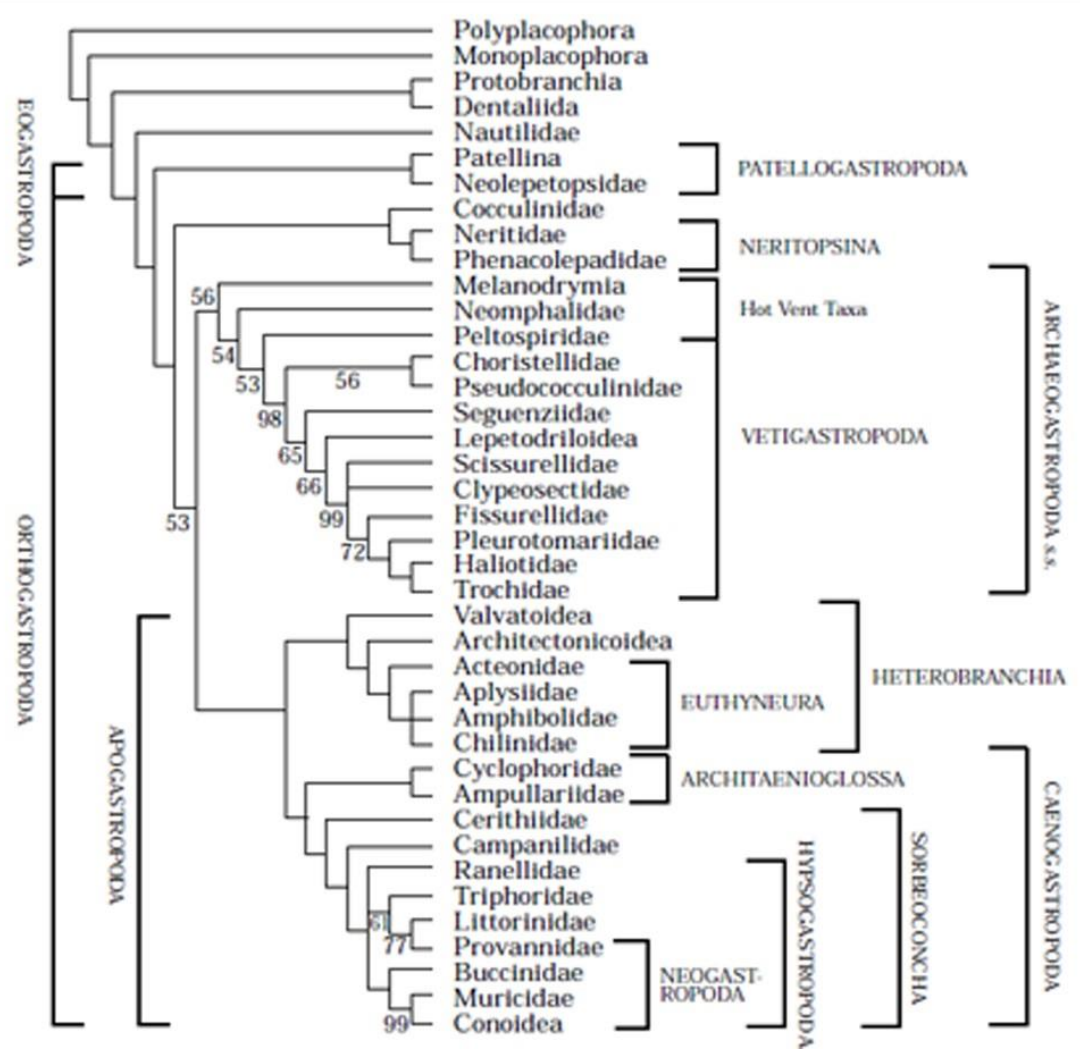

Fig. 2: Árvore extraída de Ponder (1997), que ilustra a relação de Neogastropoda mesogastrópodes", nó 77

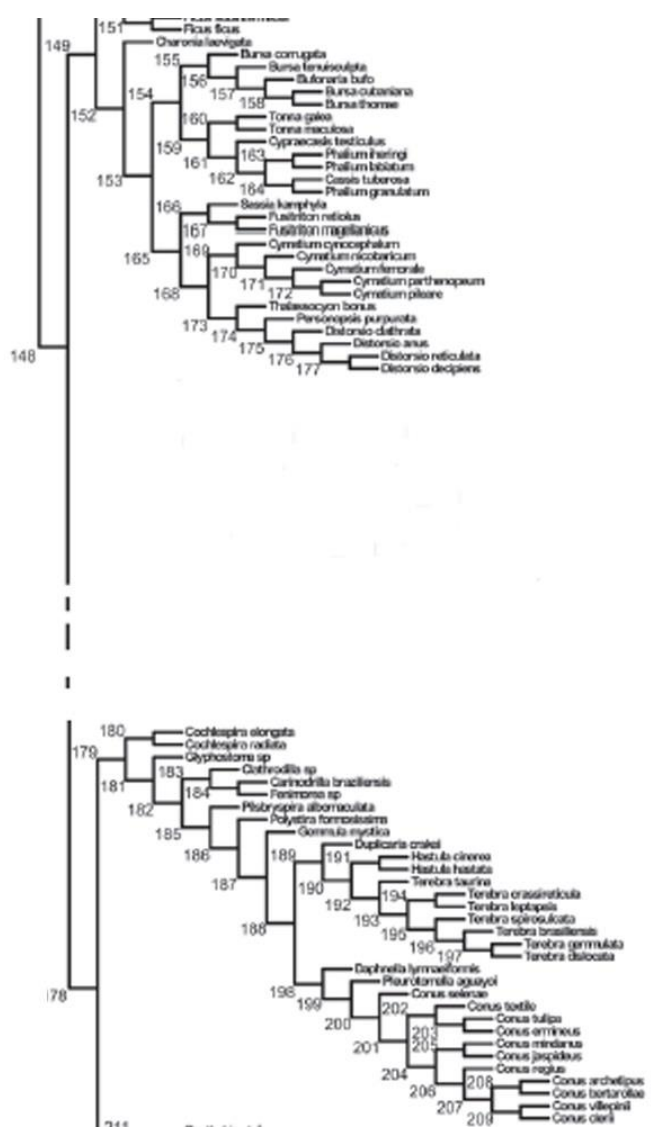

Fig. 3: Fragmento extraído de Simone (2011), que ilustra a relação de Tonnoidea com Neogastropoda, nós 148 e 178. 
Determinadas analises filogenéticas sugerem que Buccinoidea seja um táxon natural e compõem o grupo irmão dos demais neogastrópodes (Kantor, 1996; Ponder \& Lindberg, 1997).

A taxonomia supragenérica da superfamília é controversa e o número de famílias existentes podem variar de uma (Ponder, 1973) até 16 (Bouchet \& Gofas, 2015) dependendo dos caracteres adotados para a realização da análise, por conta disso é possível se fazer agrupamentos de famílias próximas, uma vez que os limites de separações entre elas não são bem definidos, um exemplo desses agrupamentos é entre as famílias Buccinidae, Nassariidae e Fasciolariidae.

A grande maioria dos trabalhos filogenéticos, até o momento, corroboram com a cumplicidade entre nassarídeos e bucinídeos. Kantor (1996) elucida essa proximidade com cinco sinapomorfias, entre elas a perda da glândula salivar acessória e alongamento do esôfago na cavidade bucal (Fig.4).

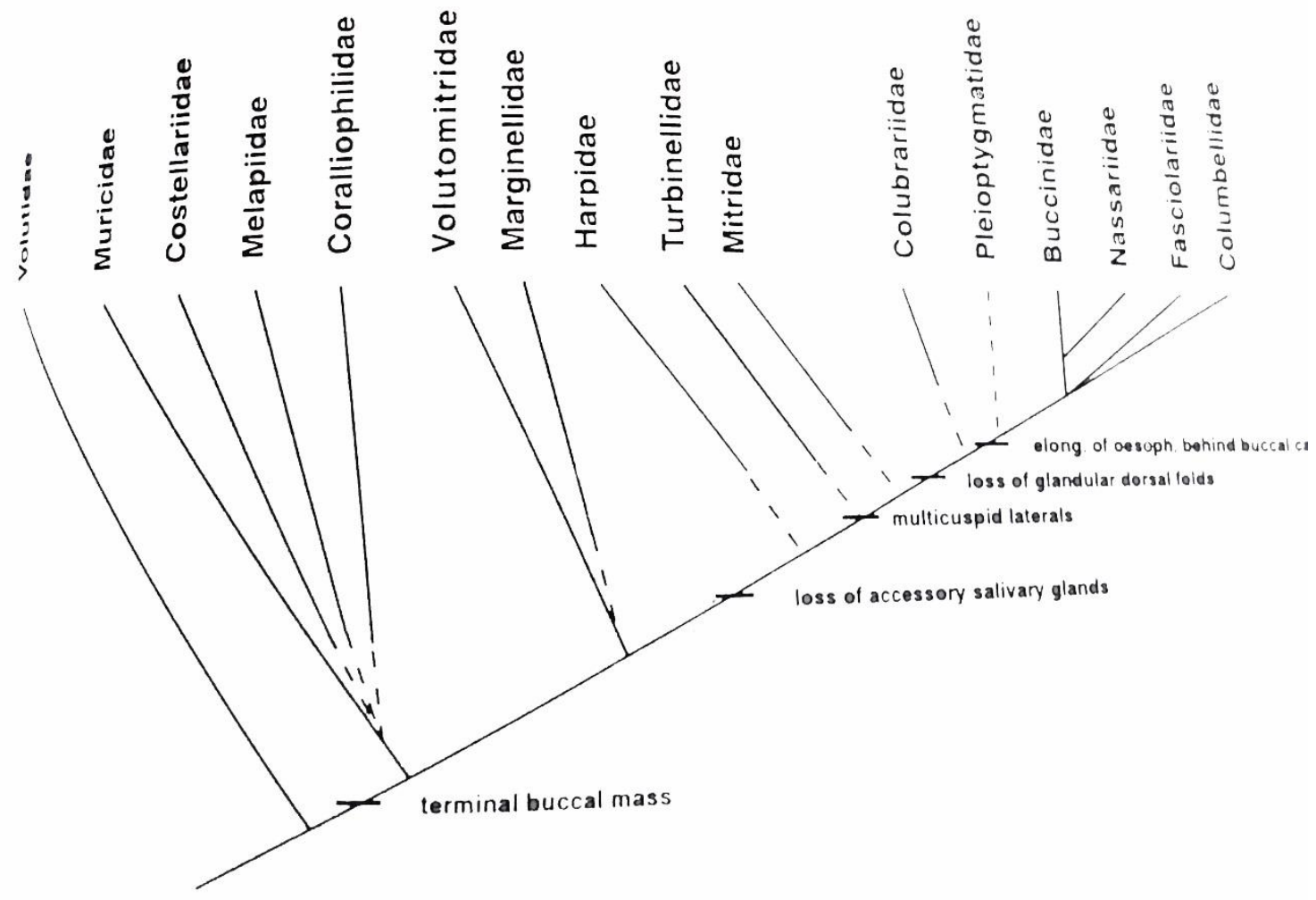

Fig. 4: Árvore extraída de Kantor (1996), que elucida a proximidade entre as famílias Buccinidae e Nassariidae.

Nesse contexto, é bom enfatizar que as relações filogenéticas dentro da família Nassariidae são mal compreendidas assim como a relação entre os nassarídeos e outros táxons da superfamília Buccinoidea, especialmente a família Buccinidae (Haals, 2000). 
Até mesmo a própria definição e abragência de Nassariidae são um tanto fluídas, variando de autor para autor.

Poucos trabalhos tratam exclusivamente da filogenia de Nassariidae baseando-se em dados morfológicos. Haals (2000) realizou uma análise filogenética da família utilizando como grupo externo algumas espécies da subfamília, de bucinídeos, Photinae, por exemplo, Antillophos; Phos e Northia Gray, 1847. Neste trabalho é sugerido que a monifilia de Nassariidae não é suportada, já que a subfamília Dorsaninae se mostrou um grupo parafilético e a subfamília Photinae resultou como sendo o grupo irmão da subfamília Nassariinae (Fig. 5).

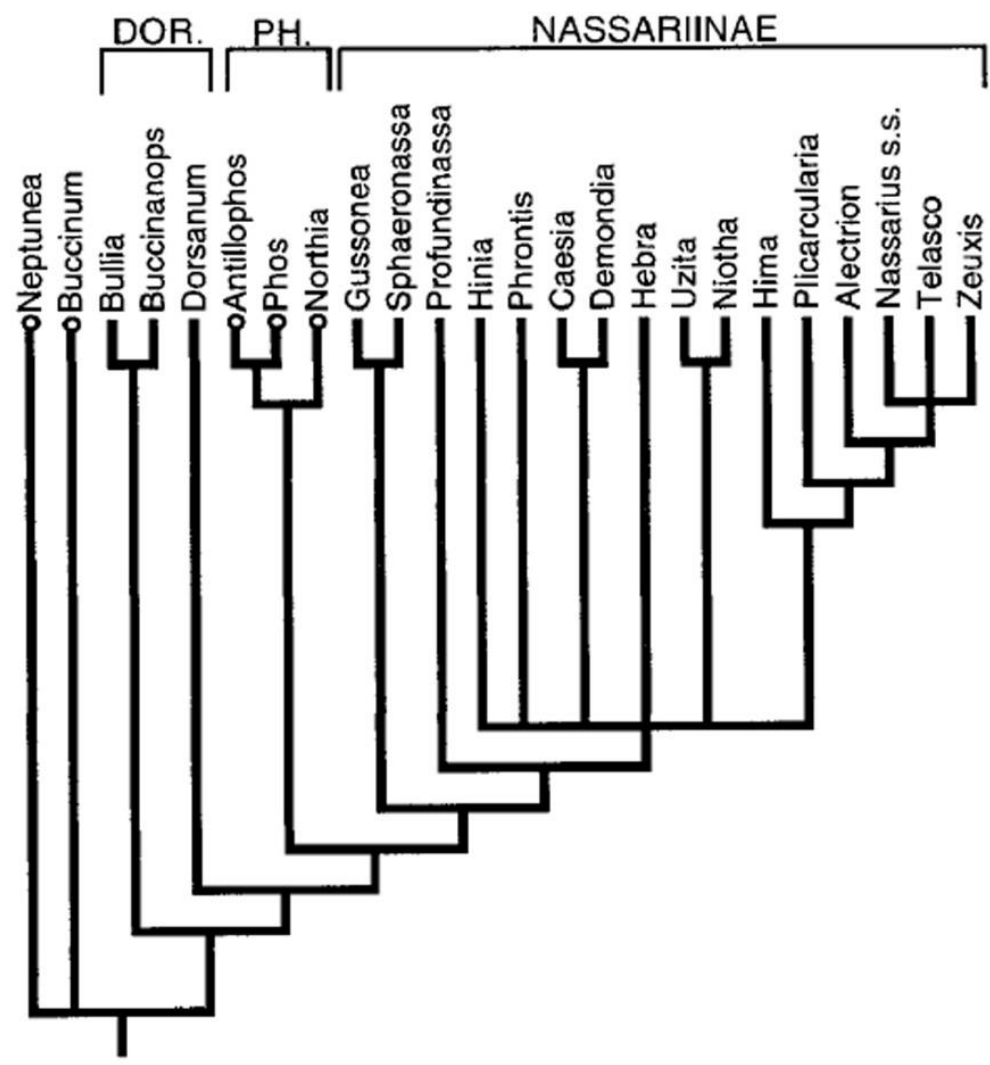

Fig. 5: Árvore extraída de Haals (2000), que ilustra o parafiletismo de Nassariidae.

Diversos trabalhos filogenéticos baseados em dados moleculares vêm sendo publicados tratando da relação entre os neogastrópodes e até mesmo específicos sobre as relações dos nassarídeos (e.g., Cunha et al. 2009; Couto et al. 2016; Galindo et al. 2016).

Esses trabalhos corroboram com a monofilia da família Nassariidae, porém, divergem quanto a sua posição dentro da ordem Neogastropoda, embora todos concordem que Nassariidae e Buccinidae mantenham estreitos laços de relação evolutiva.

Cunha (2009), baseado em hipótese de reconstrução de genoma mitocondrial (MTg), sugere que a família Nassariidae ocupa uma posição mais apomórfica dentro da 
ordem, e se posiciona como grupo irmão da família Terebridae (Fig. 6), sugerida como umas das famílias que mais passaram por modificações morfológicas (Khon, 1998).

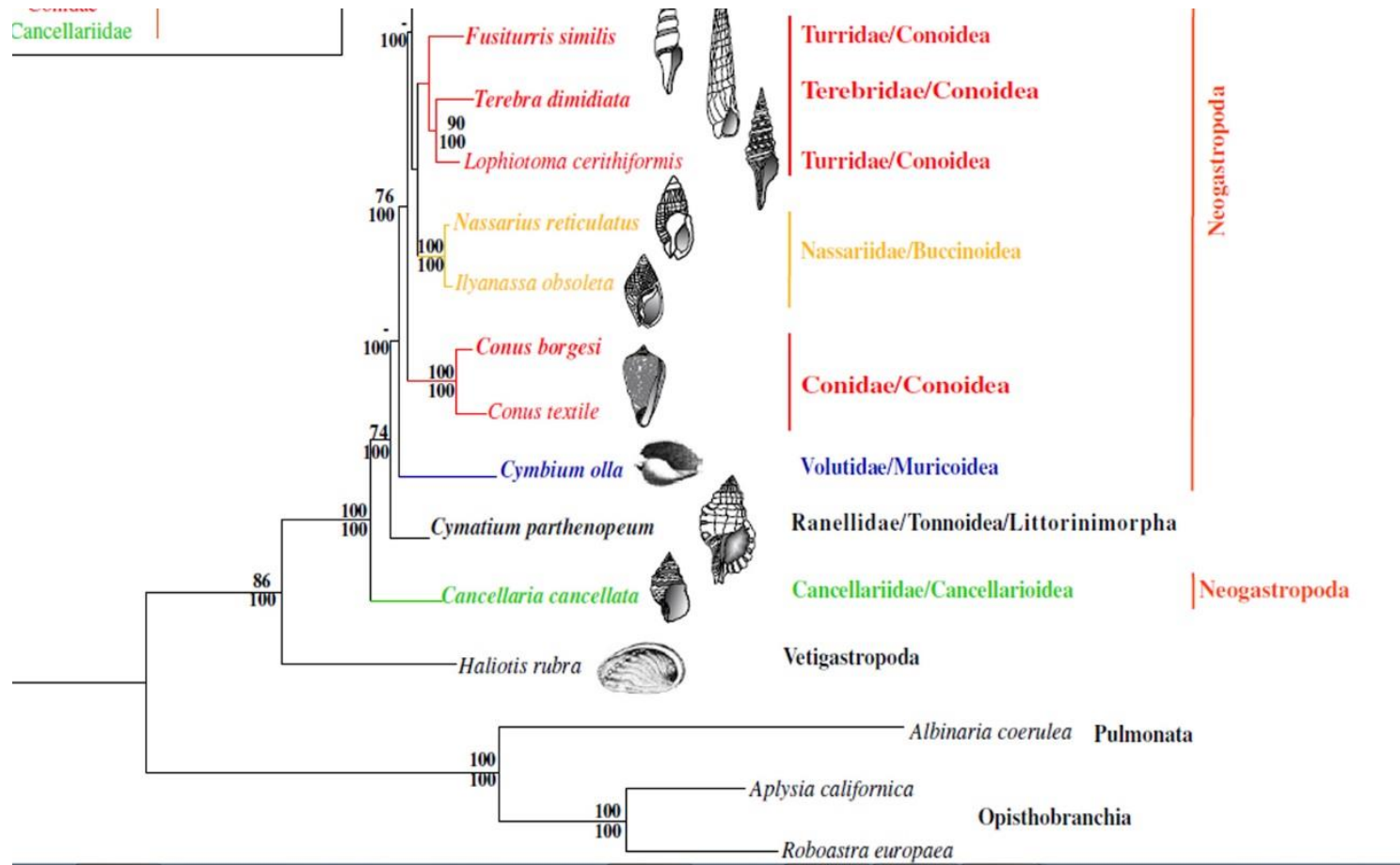

Fig. 6: Fragmento extraído de Cunha et al. (2009), ilustrando a proximidade entre Nassariidae e Coniidae.

Enquanto que Galindo (2016), também apoiada em genoma mitocondrial, COI, $18 \mathrm{~S}$ e 12S), aproxima o conjunto Nassaridae/Buccinidae aos Fasciolariidae, táxon que é considerado em uma posição mais intermediaria dentro da ordem Neogastropoda (Harasewych,1998). Além de reformular o status de algumas subfamílias de Nassariidae. (Fig. 7).

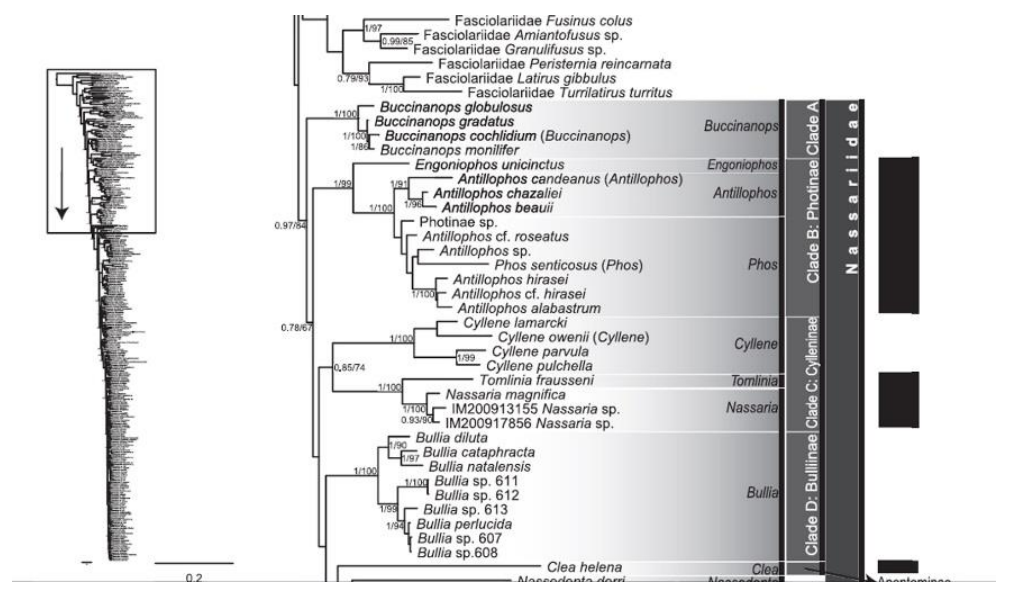

Fig. 7: Fragmento extraído de Galindo et al. (2016), que ilustra a proximidade de Nassariidae e Fasciolariidae. 


\section{Objetivos}

Essa tese tem como principais objetivos: (1) Realizar um estudo anatomico comparativo de um elenco representativo da Familia Nassariidae. (2) Estabelecer uma hipótese sobre as relaçoes filogenéticas entre essas espécies que compõe Nassariinae, suportada exclusivamente por dados morfológicos (fenotípicos) e utilizando metodologia cladistica. (3) Testar a monofilia de Nassariinae e nortear uma classificação taxonônomica para os gêneros e espécies pertencentes a familia Nassariidae.

Como objetivos secundários este estudo buscou entender as relações entre os nassarídeos e outras familias da ordem Neogastropoda inserindo o elenco de espécies selecionadas para está análise na matriz de dados realizada por Simone (2011), que abrange um cenário mais amplo entre os gastrópodes, assim como realizar um tratamento taxonômico das espécies abordadas. 


\section{Material e Métodos}

\section{Material Examinado}

Esse estudo foi realizado com material oriundo das seguintes instituições:

- Museu de Zoologia da Universidade de São Paulo-MZSP.

- The Australian Museum, Sydney-AUSM.

- Kwazulu-Natal Museum-NMSA.

- Academy of Natural Sciences of Philadelphia-ANSP.

- Muséum national d'Histoire naturelle- MNHN

- Florida Museum- UFM

Foram analisados um total de 39 espécies (lista completa abaixo), entre grupo interno e externo, pertencentes a 18 gêneros distintos da ordem Neogastropooda.

O grupo externo é composto por 14 espécies locadas em 13 gêneros não pertencentes a família Nassariidae e cinco gêneros pertencentes as outras subfamílias de Nassariidae, que não Nassariinae. A seleção deste elenco visou testar a monofolia da família Nassariidae e, em particular, da subfamília Nassariinae e posicionar esse táxon dentro da ordem Neogastropoda.

Para a representatividade de Nassariidae, foram analisados pelo menos um representante de cada gênero descrito para a família frente a luz da taxonomia atual.

Tabela I - Lista das espécies analisadas.

\begin{tabular}{|c|c|c|}
\hline \multicolumn{1}{|c|}{ Táxon } & Instituição & Número \\
Detentora & de lotes \\
\hline GRUPO EXTERNO & MZSP & 1 \\
\hline Benthobia atafona Simone, 2003 & MZSP, NMSA & 4 \\
\hline Pugilina morio (Linné, 1758) & MZSP & 37 \\
\hline Pugilina tupiniquim Abbate \& Simone, 2015 & MZSP & 18 \\
\hline Pleuroploca aurantiaca (Lamarck, 1816) & MZSP & 13 \\
\hline Turbinella laevigata Anton, 1838 & MZSP & 1 \\
\hline Vasum cassiforme (Kiener, 1840) & MZSP & 1 \\
\hline Rivomarginella morrisoni Brandt, 1968 & MZSP & - \\
\hline Pisania pusio (Linné, 1758) & MZSP & - \\
\hline Polygona ogum (Petuch, 1979) & MZSP & - \\
\hline Fusinus frenguelli (Carcelles, 1953) & & \\
\hline Leucozonia nassa (Gmelin, 1791) & & \\
\hline
\end{tabular}




\begin{tabular}{|c|c|c|}
\hline Teralatirus roboreus (Reeve, 1845) & MZSP & 1 \\
\hline Engoniophos unicinctus (Say, 1826) & MZSP & 2 \\
\hline Buccinum undatum Linné, 1758 & MZSP & 5 \\
\hline \multicolumn{3}{|l|}{ GRUPO INTERNO } \\
\hline Bullia laevissima (Gmnelin, 1791) & NMSA & 1 \\
\hline Bullia granulosa (Lamarck, 1822) & MNHN & 1 \\
\hline Dorsanum miran (Bruguière, 1789) & MNHN & 1 \\
\hline Demoulia abbreviata (Gmelin, 1791) & AUSM & 1 \\
\hline Cyclope sp. Risso, 1816 & AUSM & 1 \\
\hline Buccinanops gradatus (Deshayes, 1844) & MZSP & 2 \\
\hline Buccinanops moniliferus (Kiener, 1834) & MZSP & 4 \\
\hline Nassarius vibex (Say, 1822) & MZSP & 43 \\
\hline Nassarius arcularia (Linné, 1758) & MZSP & 1 \\
\hline Nassarius scabriusculus (Powys, 1835) & MZSP & 2 \\
\hline Phrontis alba (Say, 1826) & UFM, ANSP & 4 \\
\hline Phrontis sp. 1 & MZSP & 3 \\
\hline Phrontis sp. 2 & MZSP & 3 \\
\hline Phrontis sp. 3 & MZSP & 4 \\
\hline Phrontis sp. 4 & MZSP & 1 \\
\hline Nassarius coronatus (Bruguiere, 1789) & MZSP & 1 \\
\hline Hinia corticata (A, Adams, 1852) & AUSM & 1 \\
\hline Hinia luteostoma (Broderip \& Sowerby I, 1829) & MZSP & 1 \\
\hline Hinia pulla (Linné, 1758) & MZSP & 1 \\
\hline Hinia olivacea (Bruguiere, 1789) & MZSP & 1 \\
\hline Hinia reticulata (Linné, 1758) & MZSP & 1 \\
\hline Nassarius paucicostatus (Marrat, 1877) & MZSP & 1 \\
\hline Phrontis Incrassata (Strom, 1768) & MZSP & 1 \\
\hline
\end{tabular}

A lista completa de cada espécie contendo o material examinado, localidades, número de exemplares e instituições depositárias é apresentada no final de cada descrição.

As descrições e ilustrações contidas neste trabalho são referentes as espécies dissecadas neste período (grupo externo e interno). As que compõe o grupo externo são: Pugilina tupiniquim Abbate \& Simone, 2015; Teralatirus roboreus (Simone et al., 2013) e Bullia laevissima, (Abbate \& Simone, 2016) anexados no final deste trabalho como artigos publicados. Os demais dados das espécies que compõem o grupo externo foram angariados de publicações citadas ao longo do texto. O grupo interno encontra-se, em sua totalidade, descrito e ilustrato. 
Os dados obtidos para as espécies $P$. morio (Linné, 1758); V. cassiforme (Kiener, 1840); T. laevigata Anton, 1838 e P. auranciaca (Lamarck, 1816) foram retirados de minha dissertação de mestrado (Abbate, 2012).

Para a confirmação taxonômica especifica foram analisadas fotos dos tipos e de bibliografia pertinente, quando possível, contendo as descrições e ilustrações originais (e.g. Cernohorsky, 1988), além da dissecção de topotipos.

\section{Terminologia adotada, Dissecções e ilustrações}

O estudo morfológico foi realizado através de dissecções, com o animal em uma cuba imerso em álcool 70\%, utilizando técnicas tradicionais (Simone 2005), as dissecções foram realizadas em uma lupa estereoscópica com câmara clara utilizada nas confecções dos desenhos. Devido ao diferente tamanho entre o animal inteiro e pequenas estruturas decorrentes de uma dissecção mais aprofundada foram utilizados dois aumentos diferentes de lentes, 0,4 para estruturas maiores e 1,0 para estruturas menores.

$\mathrm{Na}$ caracterização das conchas foi utilizada a terminologia definida por Arnold (1965) e para a contagem do número de voltas da protoconcha e teleoconcha seguiu-se o método de Diver (1931) ilustrado abaixo.

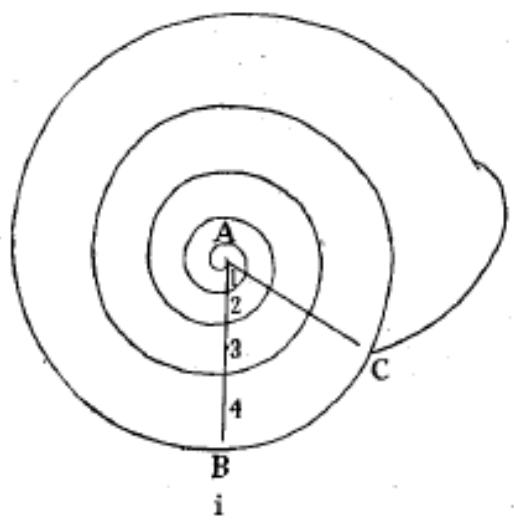

Os nomes dados às estruturas anatômicas seguiram trabalhos relacionados à classe Gastropoda, ordem Neogastropoda e superfamília Buccinoidea como, por exemplo: Fretter \& Grahan, 1962; Kantor, 1996; Simone, 2011 e Abbate \& Simone, 2015.

As descrições e abreviaturas foram escritas em inglês a fim de facilitar a composição de publicações dos dados obtidos.

O estudo das conchas se deu através da analises de suas formas e medição de seu comprimento e largura, grau da angulação da espira, contagem do número de voltas da protoconcha e teleoconcha. 
A análise dos caracteres conquiliológicos baseou-se na presença, forma e quantidades de nódulos esculturais, suturas, cordas espirais, padrão da abertura, presença ou não de ombro, presença ou não de escudo e dente parietal, altura de espira, presença ou não de canal anal.

Para ter acesso às partes moles e a topologia do animal é necessária sua extração por completo da concha, essa extração em casos particulares foi realizada com o auxílio de um gancho odontológico, mas em sua grande maioria essa extração só é possível quebrando-se a concha. As dissecções foram realizadas com técnicas tradicionais (Abbate \& Simone, 2015; Simone et al. 2013).

Foram levantados caracteres morfológicos de todos sistemas do animal, porém algumas estruturas se mostraram pouco informativas para tal levantamento, ora por apresentar pouca variação anatômica ora por serem estruturas que dificilmente se mantém em bom estado de conservação, essas estruturas foram descartadas da busca por caracteres, por exemplo, estômago, glândula hipobrânquial, glândula renal e salivar.

Para estudo da rádula foram realizadas imagens através do microscópio eletrônico de varredura (SEM) do Museu de Zoologia. A preparação do material constituiu-se no isolamento da rádula durante a dissecção do odontóforo, e posteriormente colocando-a em uma placa de petri em uma solução composta de 3/4 de água filtrada e 1/4 de hipoclorito de sódio, com a finalidade de limpar resíduos nos dentes radulares e dissolver a membrana subradular e o saco radular. É importante acompanhar esse processo em Lupa estereoscópica, pois a solução pode danificar os dentes radulares. Esse processo de limpeza leva de três a 10 minutos.

Em seguida a rádula foi colocada em um pequeno frasco em uma solução composta de $1 / 2$ de água filtrada e $1 / 2$ de limpador de uso geral e levada por três minutos ao aparelho de ultra-som. Depois de realizado o enxágue e a conferencia do material, a rádula foi fixada no stub com fita adesiva dupla face, e por fim levada à metalização e a microscopia de varredura.

Lista de Abreviaturas presentes nas ilustrações: $a a$, anterior aorta; $a b$, albumen gland; ae, anterior oesophagus; ag, albumen gland; an, anus; au, auricle; bg, buccal ganglia; $b r$, subradular membrane; $c e$, cerebral ganglion; $c g$, cement gland; $\mathrm{cm}$, columellar muscle; co, cement gland orifice; $c v$, ctenidial vein; $d f$, dorsal fold of buccal mass; $d g$, digestive gland; $d l$, gland of Leiblein duct; ep, posterior oesophagus; es, oesophagus; et, epipodial tentacle; $f g$, gill fold; $f p$, female pore; $f t$, foot; ge, suboesophageal ganglion; gi, gill; $h g$, hypobranchial gland; $k d$, kidney; $m l-m 11$, 
odontophore muscles; $m b$, mantle border; $m e$, medium oesophagus; $m j$, julgal muscle; $m o$, mouth; $m t$, mantle; ne, nephrostome; $n g$, nephridial gland; $n r$, nerve ring; oa, opercular scar; oc, odontophoral cartilage; od, odontophore; og, osphradium ganglion; $o s$, osphradium; ot, oral tube; $o v$, pallial oviduct; oy, ovary; $p a$, posterior aorta; $p b$, proboscis; $p d$, penial duct; $p e$, penis; pf, propodial expansion; $p g$, pedal gland; $p p$, penial papilla; pr, propodium; pu, pleural ganglia; $r a$, radula; $r m$, retractor muscle of proboscis; $r n$, radular nucleus; $r s$, radular sac; $r t$, rectum; ry, rincostome; $s d$, salivary duct; $s f$, siphon; $s g$, salivary gland; so, salivary duct orifice; su, subesophageal ganglia; te, tentacle; $v a$, vaginal atrium; vd, vas deferens; ve, ventricle; vo, visceral oviduct; ye, eye.

\section{Analise filogenética}

A análise foi conduzida com base nos princípios da escola Cladística de acordo com os conceitos de Hennig (1966) e as propostas subsequentes de Farris (1983) e Nixon \& Carpenter (1993). Os caracteres foram definidos com base na comparação entre os espécimes e os estados foram codificados para cada um dos terminais. Foi feita então uma busca pela árvore mais parcimoniosa, enraizada na espécie Bentobia atafona Simone, 2003. Com o enraizamento da árvore, os caracteres foram automaticamente polarizados e os clados definidos.

A seleção dos grupos externos foi baseada nas filogenias de Simone, 2011. Galindo et al. 2016; Couto et al. 2016.

Para o teste da monofila de Nassariinae foram selecionados táxons originados de outros grupos dentro da ordem Neogastropoda, por exemplo, pseudoolivídeos, turbinelídeos e fasciolarídeos além das outras subfamílias de Nassariidae.

A definição dos caracteres que foram utilizados na análise foi feita com base no estudo anatômico dos espécimes, levando-se em consideração a variação existentes nos caracteres tradicionalmente utilizados nas filogenias de gastrópodes.

Para o estabelecimento das homologias primárias foram seguidos os conceitos de de Pinna (1991) e o conceito básico de homologia topológica de Owen (Panchen, 1994).

A formulação dos caracteres foi feita de acordo com a proposta de Sereno (2007), que chama atenção para o fato de que não há um consenso na literatura sobre o modo como devem ser apresentados os caracteres. O que leva a uma situação difícil de estabelecer comparações entre propostas de caracteres de diferentes autores. Ele sugere que os caracteres sejam formulados sempre de acordo com a mesma estrutura lógica e com os mesmos componentes. 
Em seu trabalho Sereno (2007) reconhece dois tipos fundamentais de caracteres morfológicos, os neomórficos e os transformacionais, e propõe que a formulação de cada um desses dois tipos de caracteres deveria seguir uma estrutura básica. Além disso, o autor argumenta a favor da separação completa desses dois tipos de caracteres, o que leva sempre à formulação de caracteres adicionais nos casos em que determinada estrutura pode estar ausente ou presente e, ao mesmo tempo, variar com relação a algum aspecto naqueles indivíduos que a apresentam.

A matriz de táxons e caracteres foi montada com o software Nexus data editor (Page, 1998). Quando determinado caractere e/ou estado não era aplicável ao táxon foi utilizado o símbolo “_“" para a codificação, e quando o caractere e/ou estado não foi visualizado em algum táxon o símbolo adotado para a codificação foi "??”.

Essa mesma matriz foi inserida no software TNT (Goloboff et al., 2008) afim de se buscar, também, outra hipótese entre as árvores mais parcimoniosas. Após o carregamento da matriz de táxons e caracteres no programa, o número máximo de árvores a serem guardadas na memória foi ajustado para 10.000 (Max. trees $=10.000)$ e a busca foi realizada utilizando-se os recursos da busca heurística tradicional (Traditional search). O número de réplicas foi ajustado para 1.000 e o parâmetro de aleatorização (random seeds) para 1. O algoritmo de busca utilizado foi o TBR, com 100 árvores retidas por réplica.

Foi utilizado o algoritmo de pesagem implícita para os caracteres e busca do valor de K (constante de concavidade), Setk.run. O valor de "K" encontrado e utilizado é de k= 6.484375. Esta análise resultou em uma árvore mais parcimoniosa (Fig. 318). Esta árvore é apresentada e discutida abaixo.

As árvores obtidas foram salvas e carregadas, juntamente com a matriz, no software Winclada. Neste programa, foram calculados os índices de consistência (Kludge \& Farris, 1969) e de retenção (Farris, 1989). A otimização dos caracteres ambíguos também foi realizada no Winclada. Por fim, foi gerado um arquivo de imagem, com as árvores resultantes, com todos os caracteres plotados, esta foi finalizada em um programa de edição de imagens. Utilizando-se a mesma matriz de dados e metodologias descritas acima, a árvore de consenso estrito foi gerada pelo software Winclada utilizando o recurso "consensus compromise (strict) e é apresentada a seguir.

A otimização dos caracteres (ACCTRAN ou DELTRAN) foi feita caso a caso, através da análise da distribuição das transformações de cada um dos caracteres 
ambíguos, como sugerido por Agnarsson \& Miller (2008), visando-se manter as transformações como sinapomorfias que sustentassem os clados da análise.

Para fins de otimização, discussão e apresentação dos caracteres, taxonomia e conclusões foi adotada a topologia da árvore de pesagem implícita (Figs. 318, 319 e 320).

Para a compreensão das relações dos nassarídeos com as outras famílias da ordem Neogastropoda foi inserido o mesmo material analisado (36 táxons), na matriz confeccionada por Simone (2011) em sua filogenia de Caenogastropoda. Foram codificados 676 caracteres, nenhum estado adicional teve de ser criado. A matriz contendo essa inserção está representada abaixo.

A metodologia utilizada para a análise destes dados é a mesma descrita acima e a árvore de consenso gerada (Fig. 322), a partir de 40 árvores mais parcimoniosas retidas, e seus índices estão apresentadas a seguir.

\section{Resultados e discussões}

\section{Descrições Taxonômicas}

Family Melongenidae

Genus Pugilina Schumacher, 1817

Type species: Pugilina fasciata Schumacher, 1817 (= Murex morio Linné, 1758) by monotypy.

\section{Pugilina tupiniquim sp. n.}

Description see annex 1 .

\section{Family Fasciolariidae}

Genus Teralatirus Coomans, 1965

Type species: Latirus ernesti, Melvill, 1910.

Teralatirus roboreus (Reeve, 1845).

Description see annex 2.

\section{Family Marginellidae}

\section{Genus Rivomarginella Brandt, 1968}

Type species: Rivomarginella morrisoni Brandt, 1968, by monotypy.

Rivomarginella morrisoni Brandt, 1968

Figs. 8-21.

Shell (Figs 8,9). Fusiform with lateralization, twice as long as wide, with 8 or 9 convex whorls; color pale orange to white. Protoconch wide, smooth, dome-shaped, white, with two whorls; transition unclear. Teleoconch smooth, sculpture consisting in 
shallow sutures in the first three whorls. Spire angle $\sim 76^{\circ}$. Aperture long, elliptical, three times long as wide, white, glossy; length $\sim 90 \%$ of shell length. Siphonal canal as a convex area, like a sinus shape. Anal notch weakly indicated. Outer lip thick and smooth. Columella straight, with tree well marked folds.

Head-foot (Figs 10-13). Pallial cavity covering 5/6 of total animal length; muscular siphon located on center, length $\sim 1 / 6$ of head-foot length. Head not protruded; tentacles base next from each other, elongated and narrow, twice as long as head; eyes absent. Foot large, occupying whole body whorl (retracted), flat; pedal gland located in central region of anterior edge of foot (Figs 11, 13), forming a groove, extending from anterior region to posterior end of sole. Penis originated in right lateral region, posterior to tentacle base, at level of mantle edge. Columellar muscle short and wide, one whorl long. Haemocoel short and wide, extending dorsally along center of foot and columellar muscle, $1.5 \mathrm{x}$ as long as wide (Fig. 12). Operculum absent.

Mantle organs (Fig. 14). Mantle cavity covering $\sim 2$ whorls. Siphon width 1/4 of mantle cavity width, length $\sim 1 / 6$ of mantle cavity length. Right base of siphon low, width same as mantle edge width; left base low, ending gradually. Osphradium long and wide, elliptical, length $\sim 1 / 2$ of pallial cavity length, width $\sim 1 / 4$ of its width. Osphradial filaments long, separated, similar to fingers, width twice the mantle edge. Ctenidial vein (efferent branchial vessel) uniformly narrow along its length. Gill elliptic, occupying $\sim 80 \%$ of length and width of pallial cavity. Anterior end of gill rounded, ending gradually, inserted directly into pallial cavity. Gill filaments subtly increasing in size in posterior region, decreasing at anterior end. Posterior end of gill rounded, located in posterior region of mantle cavity, inserted into pericardium. Gill filaments large, occupying $~ 2 / 3$ of pallial cavity height, apex rounded; space between gill and right pallial organs about $\sim 1 / 3$ of gill width. Hypobranchial gland inconspicuous. Right side of pallial cavity almost entirely filled by gonoducts. Rectum short and thick, occupying $\sim 1 / 12$ of pallial cavity. Anus siphoned, distance between anus and mantle border $\sim 2 / 3$ of total pallial cavity length. Anal gland absent.

Visceral mass (Figs. 10, 14). About 1.5 whorls posterior to mantle cavity. Digestive gland dark beige, occupying $\sim 60 \%$ of visceral mass, encircling stomach. Gonad orange with small black spots, located on columellar surface, posterior to stomach. Seminal vesicle of males located in anterior portion of gonad, $\sim 1 / 2$ of its size. Kidney occupying $\sim 1 / 2$ of visceral mass volume, located on right side of anterior visceral end. Stomach not seen in detail. 
Circulatory and excretory systems (Figs. 14, 20, 21). Reno-pericardial region occupying 1 whorl, on right margin of last whorl of visceral mass, adjacent to mantle cavity; oval shaped. Pericardium occupying 1/4 of reno-pericardial region, posterior to gill; situated on left anterior margin of visceral mass. Auricle membraneous, anterior to ventricle; with three connections: on upper right side with kidney, on anterior right side with gill, and on posterior left side with ventricle. Ventricle two times as large as auricle, with common aorta in left posterior margin. Common aorta small, located along posteroleft region of ventricle. Kidney occupying $1 / 7$ of pallial cavity, renal lobe single, solid, with glandular chamber in its ventral surface; efferent renal vessel located at its right portion. Nephridial gland not seen in detail. Nephrostome small, as transverse slit, located in anterior region of membrane between kidney and pallial cavity.

Digestive system (Figs. 15-17). Mouth longitudinal, narrow. Proboscis short and wide, occupying $~ 80 \%$ of haemocoel. Rhynchodeal wall thick and muscular, involving $2 / 3$ of proboscis. Pair of strong retractor muscles covering posterior end of proboscis; pair of thick retractors, originated on ventral surface of haemocoel, inserted into middle surface of proboscis. Odontophore and buccal mass muscles absent. Salivary glands located at right region of haemocoel, occupying $\sim 1 / 8$ of haemocoel volume, entirely involving nerve ring, middle esophagus and middle-right portion of proboscis. Salivary ducts very small and narrow. Valve of Leiblein large, about 1/4 of middle esophagus lenght, located anterior to nervous ring, anterior region with transverse white band bearing long cilia, middle and posterior regions white, corresponding to inner gland occupying most of inner surface; bypass not visualized. Accessory salivary glands absent. Anterior esophagus broad, twice wider than middle esophagus; occupying entire length of proboscis. Middle esophagus short. Posterior esophagus $\sim 80 \%$ of total haemocoel volume, transverel, broad, tapering posteriorly; anterior end with cecum, about twice diameter of posterior end, differentiation between middle and posterior esophagus clear. Stomach not analyzed; digestive gland ducts not analyzed in detail.

Genital system. Male (Fig. 19). Visceral structures not seen in detail. Vas deferens narrow, simple, straight, running along ventral surface of kidney up to pallial cavity. Prostate totally closed (tubular), running thought right mantle edge, at $\sim 2 / 3$ of total pallial cavity length. Vas deferens anterior to prostate, straight, running immersed into integument of dorsum, next to mantle border and penis base. Penis short, broad, length $\sim 1 / 4$ of total head-foot length, dorso-ventrally flattened and with wide point at base, apical 
region pointed. Penial duct straight, running through center of penis, closed (tubular). Penial aperture apical, very small.

Female (Figs. 14, 20, 21). Visceral oviduct narrow, straight, running along ventral surface of kidney in first whorl of visceral mass, located in front of pallial cavity. Posterior region of pallial oviduct protruding into kidney, occupying $1 / 2$ of length of pallial cavity and 1/8 of its width. Albumen gland posterior, whitish, thin-walled, occupying $~ 1 / 4$ of pallial oviduct. Capsule gland $\sim 4 / 5$ of oviduct, elongated, orange, thick-walled. Vaginal atrium anterior to capsule gland occupying 1/6 of oviduct; walls thin, muscular, female genital pore small. Bursa copulatrix absent. Cement gland absent.

Central nervous system (Fig. 18). Nerve ring located in ventral middle proboscis region, occupying $~ 1 / 11$ of haemocoel volume, highly concentrated. Ganglia mostly fused, hard to distinguish from each other, somewhat asymmetrical. Pairs of pleural and cerebral ganglia fully fused with each other. Pair of small buccal ganglia, about half of pleural ganglia, located on ventral surface of pleural ganglia, connected by thin commissure. Sub-esophageal ganglion about as large as cerebral ganglion. Esophageal aperture small, occupying about $\sim 1 / 9$ of ventral surface of nerve ring. Statocysts not seen.

Shell measurements (length $x$ width in $\mathrm{mm}$ ): $2 \AA 5.7$ x 3.5; 5.2 × 3.3; 2 5.7 x 3.5; $5.5 \times 3.5$.

Distribution: Thailand.

Habitat: Mud bottoms, rivers.

Material examined: AUSM C383572; 2へ, 2ㅇ, Thailand: Kabinburi; Prachin River, $13^{\circ} 58^{\prime} \mathrm{N}, 101^{\circ} 42^{\prime} \mathrm{E},(\mathrm{R}$, Brandt col., 21/i/1965). 


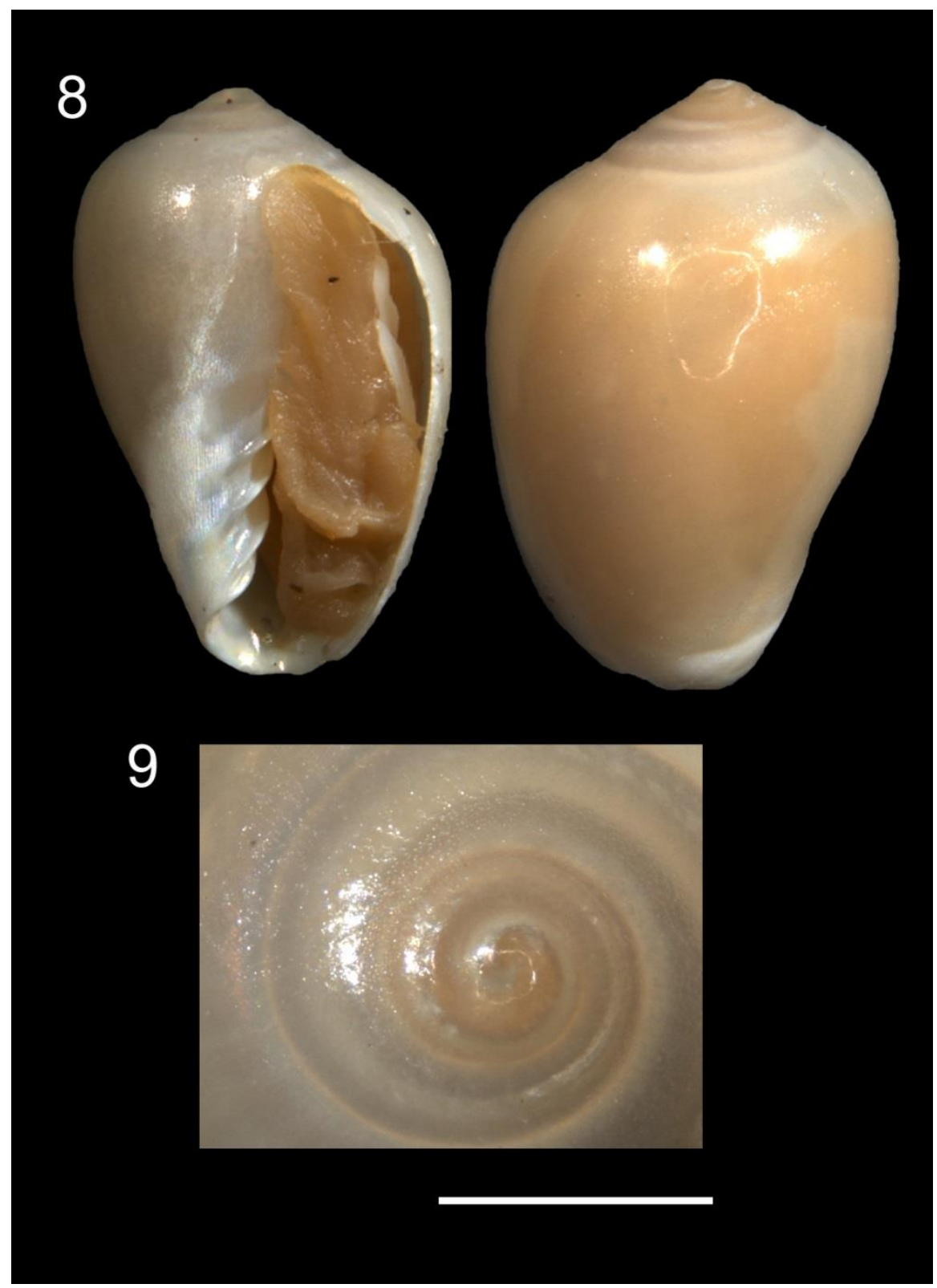

Figs 8-9: Rivomarginella morrisoni: AUSM C 383572 Fig. 8: Apertural and dorsal view, (L 5,7 $\mathrm{mm}$ ); Fig. 9: Shell, apical view, scale bar: $2 \mathrm{~mm}$. 

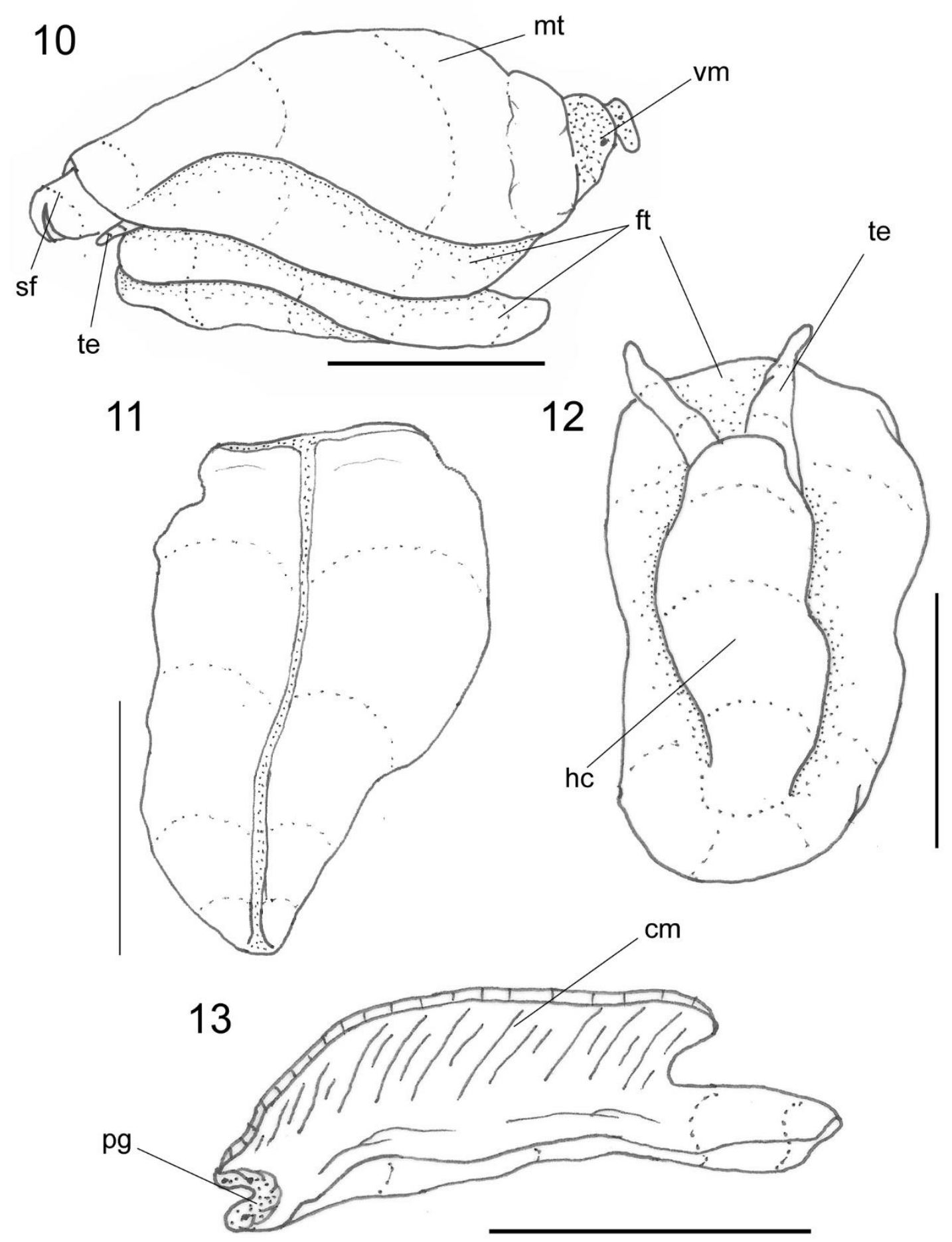

Figs 10-13: Rivomarginella morrisoni; Fig. 10: Entire animal, lateral view; Fig. 11: Sole detail, groove of pedal gland exposed; Fig. 12: Head foot ventral view. Scales bar: $2 \mathrm{~mm}$. 

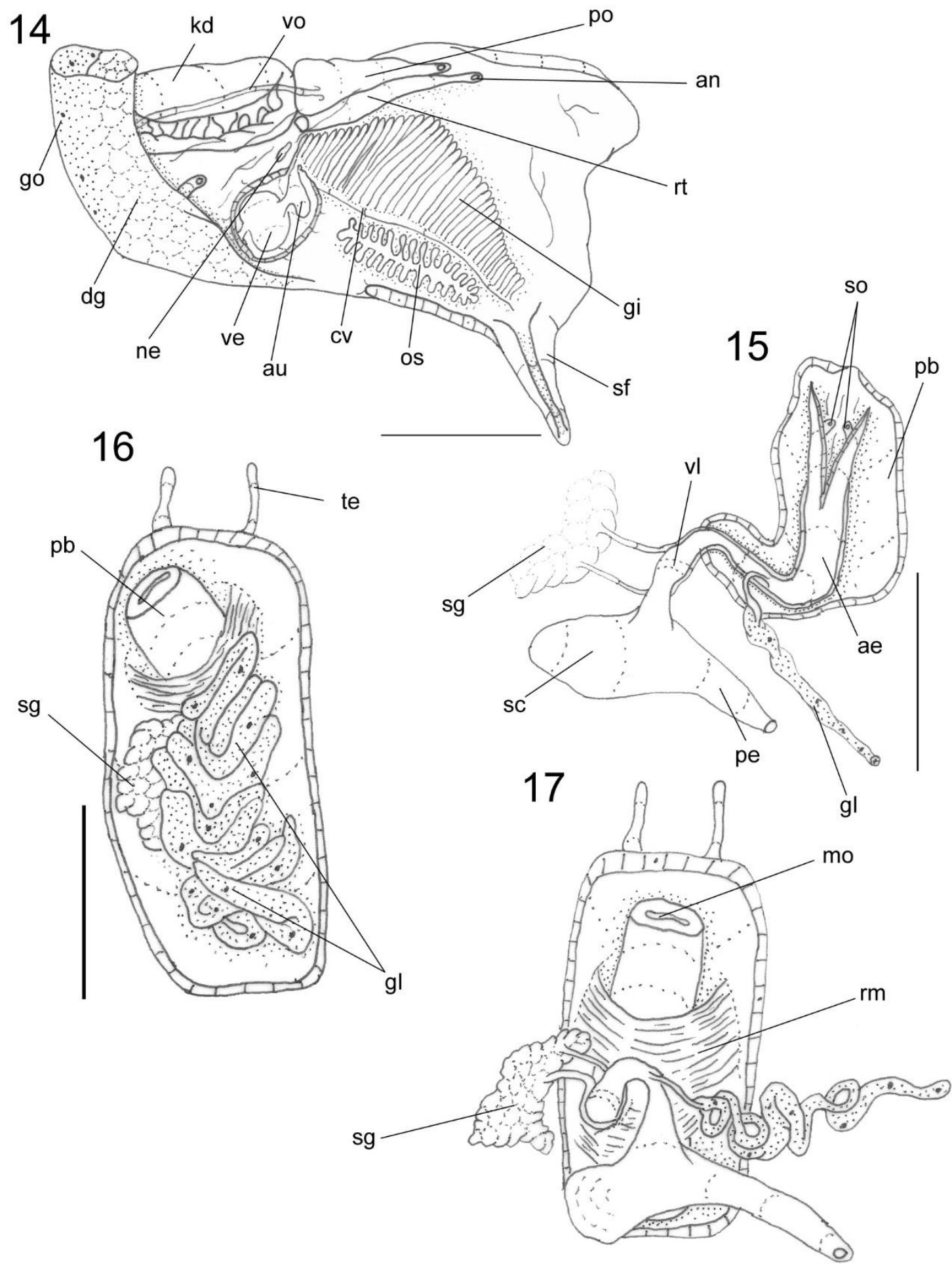

Figs. 14-17: Rivomarginella morrisoni: Fig. 14: Palial Cavity, palial organs exposed; Fig. 15: Detail of foregut; Fig. 16: Haemocoel topology; Fig. 17: Same, detail of medium esophagus, duct of gland of Leiblein and Valve of Leibein. Scales bar $=2 \mathrm{~mm}$. 

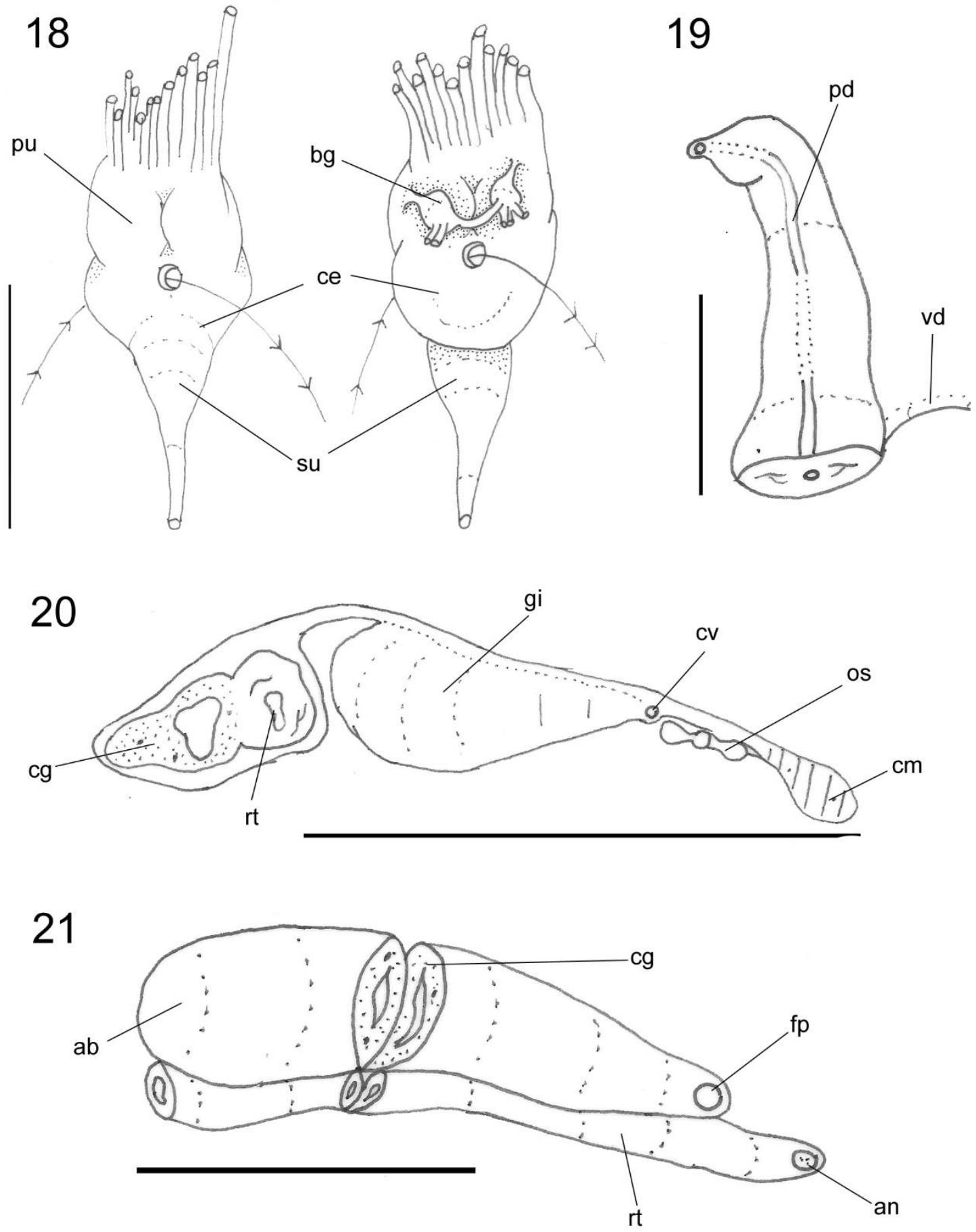

Figs. 18-21: Rivomarginella morrisoni: Fig. 18: Nerve ring, ventral and dorsal view. Scale bar: 1mm; Fig. 19: Penis, ventral view, scale bar: 0,5 mm; Fig. 20: Pallial cavity roof, transverse section at middle level of osphradium, scale bar: $2 \mathrm{~mm}$; Fig. 21: Pallial oviduct, ventral view, transversely sectioned in its middle level, some adjacent structures also shown, scale bar: $1 \mathrm{~mm}$. 


\section{Family Nassariidae \\ Subfamily Nassariinae Iredale, 1916 \\ Tribe Bullini tribe nov. \\ Genus Bullia Gray, 1834 in Griffith \& Pidgeon}

Type species: B. semiplicata Gray in Griffith \& Pidgeon, 1834, by monotypy.

\section{Bullia laevissima (Gmelin, 1791)}

Buccinum laevissimum Gmelin, 1791: 3027.

Buccinum laevigatum Lamarck, 1822: 269.

Bullia sowerbyi Turton, 1932: 138-173.

Bullia laevissima Pacaud, 1833; Carr, 1967: 106; Willows, 1973: 187; Brown, 1961: 629; 1971; 1979: 573; 1982:309-361; Trueman \& Brown, 1976: 365; 1989: 129; Dye, 1980:108; Cernohorsky, 1984: 22; Cockcroft, 2002: 491; Kruger, 2005

Description see annex 3.

\section{Tribe Photini tribe nov.}

\section{Genus Engoniophos Woodring, 1928}

Type species: Phos erectus Guppy, 1873 by original designation. Miocene, Jamaica.

\section{Engoniophos unicinctus (Say, 1826)}

Figs. 22-46

Nassa unicincta Say, 1826: 211-212 (pl. 57, figs 1, 1a); Tryon, 1873: 35 (fig. 55), 1882: 245.

Nassa pallida Powys, 1835: 96.

Nassa guadelupensis Petit de la Saussaye, 1852: 171 (pl. 2, figs 3-4).

Strongylocera textilina Mörch, 1852: 80 (Lister, pl. 965, fig. 20).

Phos guadalupensis [sic]: Arango, 1880: 201.

Phos guadeloupensis [sic]: Tryon, 1881: 219 (pl. 83, figs 512, 520).

Nassa textilina: Tryon, 1882: 243.

Phos unicinctus: Dall, 1889: 178; Gardner, 1926: 460.

Strongylocera unicincta: Dall \& Simpson, 1901: 402.

Engoniophos guadelupensis: Warmke \& Abbott, 1962: 115 (pl. 21, fig. F); Humfrey, 1975: 150; Bandel, 1976: 99 (fig. 3a-b).

Engoniophos unicinctus: Rehder, 1962: 131; Warmke \& Abbott, 1962: 116 (pl. 21, fig. J); Work, 1969: 672; Abbott, 1974: 220 (fig. 2428); Vokes \& Vokes, 1983: 26 (pl. 14, fig. 21); Bandel, 1984: 142 (fig. 235; pl. 16, fig. 6); Jong \& Coomans, 1988: 83 (pl. 38, fig. 455); Díaz \& Puyana, 1994: 187; Ramos \& Robaina, 1994: 102; Faber, 2004: 8; Buitrago et al., 2006: 639; Cruz \& Gándara, 2006: 132; Fernández \& Jiménez, 2007: 5; Reyes et al., 2007: 384; Rosenberg et al., 2009: 650.

Pallacera unicincta: Macsotay \& Campos, 2001: 88. 
Shell (Figs. 22, 24, 25). Fusiform, twice as long as wide, with 7-8 convex whorls, light gray to cream. Protoconch wide, smooth, dome-shaped, white, with three whorls; transition unclear. Teleoconch sculpture consisting 5-8 thin spiral cords along entire surface on all whorls (twice as many on body whorl); space between cords equals three to four times their width, becoming more closely packed near suture; spiral cords crossed by wide axial ribs (width $~ 1 / 10$ of whorl width) bearing rounded nodules at middle level on earlier whorls, and on upper portion of body whorl; axial ribs becoming less prominent toward suture and basal portion of body whorl; depression between ribs as wide as ribs themselves. Spire angle $\sim 30^{\circ}$. Aperture elliptical, twice as long as wide, white, glossy; length $\sim 1 / 2$ of shell length. Siphonal canal short, broad, dorsally recurved. Anal notch present, but not well-marked. Outer lip thick, lirate, with thickened outer edge. Columella straight, without folds.

Head-foot (Figs. 29, 30, 32, 34). Head protruded, socket-like; tentacles separated from each other by space $\sim 1 / 2$ head, elongated and narrow, twice as long as head; eyes located on small protuberances at mid level of tentacle, clearly separating basal broad and distal narrow portions. Rhynchostome as transverse slit, located in middle region of ventral surface of head. Foot large, occupying whole body whorl (retracted), bearing pair of small propodeal expansions; pedal gland located in central region of foot (Fig. 34), forming groove, extending from dorsum of foot (propodium) to sole. Cement gland of females rounded, located in anterior region of mesopodium, inner space wide, duct long (Fig. 32). Cement gland orifice located on median line of anterior sole region (Fig. 34). Opercular pad elliptical, $\sim 80 \%$ as wide as dorsal surface of foot; attachment with operculum occupying $\sim 70 \%$ of foot area. Penis originated in right lateral region, posterior to cephalic base, at level of mantle edge. Columellar muscle wide and broad, 11/2 whorl long. Haemocoel long and thin, extending dorsally along center of foot and columellar muscle.

Operculum (Fig. 23). Small, oval, corneous, pale brown, located close to edge of foot; occupying 1/2 of apertural area. Nucleus terminal, inferior. Outer surface with normal concentric growth lines, forming undulations. Scar oval, occupying $\sim^{2} / 3$ of inner surface.

Mantle organs (Figs. 31, 33, 35). Mantle cavity covering 1 whorl. Siphon width $\sim 1 / 2$ of mantle cavity width, length $\sim 2 / 3$ of mantle cavity length. Right base of siphon high, width $\sim$ twice mantle edge width; left base low. Osphradium long and narrow, elliptical, length $\sim 1 / 3$ of pallial cavity length, width $\sim 1 / 6$ of its width. Osphradial 
filaments short, width similar to mantle edge. Ctenidial vein (efferent branchial vessel) with uniformly narrow along its length. Gill elliptic, occupying $~ 80 \%$ of length and $\sim 1 / 4$ of width of pallial cavity. Anterior end of gill rounded, ending gradually, inserted directly into pallial cavity. Gill filaments relatively uniform in size along its entire length. Posterior end of gill rounded, located in posterior region of mantle cavity close to pericardium. Gill filaments height $\sim 1 / 3$ of that of pallial cavity, apex rounded, at middle portion, tilted to right; right and left edges of filament straight; space between gill and right pallial organs about twice of gill width. Hypobranchial gland inconspicuous. Right side of pallial cavity almost entirely filled by gonoducts. Rectum long and thin, with $\sim 1 / 2$ of pallial cavity length. Anus sessile, distance between anus and mantle border $1 / 3$ of total pallial cavity length. Anal gland absent.

Visceral mass (Figs. 31, 33). Extending $~ 3$ whorls posterior to pallial cavity. Digestive gland dark beige, occupying $\sim 80 \%$ of visceral mass, encircling stomach. Gonad orange with small black spots, located on columellar surface, posterior to stomach. Seminal vesicle of males located in anterior portion of gonad, $\sim 1 / 2$ of its size. Kidney occupying $\sim 1 / 3$ of visceral mass volume, located on right side of anterior visceral end. Stomach not seen in detail.

Circulatory and excretory systems (Fig. 31, 33, 35, 46). Reno-pericardial region occupying $1 / 3$ of whorl, oval, on right margin of last whorl of visceral mass, adjacent to mantle cavity. Pericardium occupying $1 / 3$ of reno-pericardial region, posterior to gill; situated on left anterior margin of visceral mass. Auricle reniform, anterior to ventricle; with three connections: on upper right side with kidney, on anterior right side with gill, and on posterior left side with ventricle. Ventricle four times larger than auricle, with common aorta on left posterior margin. Aortas wide, located along postero-left region of ventricle. Kidney occupying $1 / 5$ of pallial cavity volume, renal lobe single, solid, with glandular transverse folds along its ventral surface; efferent renal vessel located at its right portion. Nephridial gland not seen in detail. Nephrostome as small, transverse slit, located in anterior region of membrane between kidney and pallial cavity.

Digestive system (Figs. 30, 36-42). Mouth longitudinal, narrow, located at middle proboscis' tip. Proboscis long, straight and thin, occupying $~ 80 \%$ of haemocoel; not completely retractable. Rhinchodeal wall thin, involving $\sim 1 / 3$ of proboscis. Retractor muscles covering $\sim 1 / 3$ of proboscis; several thin retractor muscles originated on dorsal surface of foot, inserted into posterior end surface of proboscis. Odontophore and buccal mass muscles: $m j$, thin pairs of perioral muscles connected on both sides, dorsal and 
ventral, surrounding odontophore cartilages; $m l$, jugal muscles, several small muscle fibers connecting buccal mass to adjacent inner surface of proboscis; $m 2$, pair of strong retractor muscles of buccal mass, originating on inner surface of proboscis, running along entire odontophore, inserting in anterior region of odontophore cartilages; $m 2 a$, pair of retractor muscles of buccal mass, originating on dorsal surface of haemocoel, inserting at end of posterior margin of odontophore cartilages; $m 2 b$, ventral single, thin muscle auxiliary of $\mathrm{m} 2$, originating on ventral medial fibers of $\mathrm{m} 2$, detaching from it in region just posterior to $\mathrm{m} 6 ; \mathrm{m} 3$, long, $\sim 80 \%$ of odontophore length, cylindrical muscle forming outer wall of odontophore, with transverse fibers; $m 4$, pairs of strong radular dorsal tensor muscles covering almost entire surface of posterior portion of odontophore cartilages, inserting into subradular membrane; $m 5$, pair of auxiliary dorsal tensor muscles of radula, originating inside edges of cartilage, adjacent to insertion of $\mathrm{m} 4 ; m 6$, horizontal muscle, thick, connecting ventral edges of cartilages, running almost along its entire length; $m 8$, pair of small elliptical muscles, length $\sim 1 / 3$ of odontophore cartilage length, originating at anterior end of odontophore cartilages, running along ventral surface of odontophore, inserting on anterior ventral surface of cartilages; $m 11$, pair of ventral tensor muscles of radula, elongated, about $1 / 2$ of total odontophore length, originating at ventral-posterior end of cartilages, crossing ventrally entire odontophore, inserting into ventral posterior surface of radula. Additional odontophore structures: $b r$, subradular membrane, thin, translucent, along entire length of radular ribbon, covering inner surface of odontophore cartilages; $o c$, odontophore cartilages, about 3 times as long as wide, inner ventral surface concave, $\sim 1 / 4$ of anterior end fused with each other, $\sim 1 / 3$ of anterior region, concave, involving radular ribbon; $r s$, radular sac thin-walled, cylindrical, located at posterior end of radula. Radula (Figs. 26-28): rachidian tooth wide, comb-like, occupying about half of radular width; base curved, width $\sim 3 \times$ its length; $\sim 9$ triangular, sharp pointed cusps of similar size, except for some diminishment towards side; lateral tooth hook-like, bicuspid, base broad (equivalent to rachidian base width), obliquely disposed; main lateral cusp widely curved inwards, about as long as base; secondary cusp approximately half size of main lateral cusp. Salivary glands small, located at anterior portion of haemocoel, occupying $\sim 1 / 8$ of haemocoel volume, entirely involving nerve ring, middle esophagus and anterior portion of proboscis. Salivary ducts very narrow, except for short proximal region running completely attached to anterior esophagus wall and, more anteriorly, inside dorsal folds of buccal cavity; opening very small, in anterior-middle region of dorsal folds of buccal cavity. Valve of Leiblein large, about 1/8 of odontophore 
volume, located in medium esophagus anterior to nervous ring, anterior region with transverse white band bearing long cilia, middle and posterior regions white, corresponding to inner gland occupying most of inner surface; bypass absent. Gland of Leiblein narrow and elongated, twice as long as middle esophagus, becoming gradually narrower posteriorly; duct of gland of Leiblein straight, long and very narrow, length $\sim 1 / 2$ of medium esophagus length, width $\sim 1 / 6$ of medium esophagus width. Accessory salivary glands absent. Anterior esophagus broader; walls muscular, with several dorsal internal longitudinal folds, occupying entire length of proboscis. Middle esophagus slender, short, diameter and length approximately half those of anterior esophagus. Posterior esophagus narrow, straight, about as long as anterior esophagus; anterior region broad, differentiation between middle and posterior esophagus clear with thin duct. Stomach not seen in detail.

Genital system. Male (Fig. 43). Vas deferens narrow, simple, straight, running along ventral surface of kidney up to pallial cavity. Prostate totally closed (tubular), running thought right mantle edge, at $\sim 2 / 3$ of total pallial cavity length. Vas deferens anterior to prostate, straight, running immersed into integument of dorsum, next to mantle border and penis base. Penis large, length $\sim 1 / 2$ of total head-foot length, dorso-ventrally flattened; base curved, apical region pointed. Penial duct straight, running through center of penis, closed (tubular). Penial papilla long, slender, subterminal, located at anterior left region of penis. Penial aperture apical, far from papilla.

Female (Figs. 31, 33, 35, 46). Visceral oviduct narrow, straight, running along ventral surface of kidney in first whorl of visceral mass, located in front of pallial cavity. Posterior region of pallial oviduct protruding into kidney, occupying almost entire length of pallial cavity and 1/3 of its width. Albumen gland posterior, whitish, thick-walled, occupying $\sim 1 / 5$ of pallial oviduct. Capsule gland $\sim 4 / 5$ of oviduct, elongated, orange, thick-walled. Vaginal atrium anterior to capsule gland occupying $\sim 1 / 7$ of oviduct; sinuous, walls thick, muscular, female genital pore narrow, protruded, papilla-like, with thick edges. Bursa copulatrix absent.

Central nervous system (Figs. 44, 45). Nerve ring located in ventral basal proboscis region (Fig. 15: nr), occupying $\sim 1 / 12$ of haemocoel volume, highly concentrated. Ganglia mostly fused, hard to distinguish from each other, somewhat asymmetrical. Pairs of pleural and cerebral ganglia fully fused with each other. Subesophageal ganglion about half of the cerebro-pleural ganglion size, shortly and broadly connected to right cerebral ganglion. Pair of buccal ganglia small, located close to 
posterior edge of cerebral ganglia. Esophageal aperture small, occupying about 1/9 of ventral surface of nerve ring. Statocysts not visualized.

Shell measurements (length $x$ width in $\mathrm{mm}$ ): MZSP 77798; 2 ^ 20.7 x 10.4; 17.5 x $9.0 ; 2 q 13.9 \times 6.1 ; 18.7 \times 9.5$.

Distribution: Lower Caribbean to Venezuela (Macsotay \& Campos, 2001).

Habitat: Mud and sand bottoms, intertidal.

Material examined: MZSP 77798;2ð̄, 2ᄋ, Venezuela: Isla Margarita; Playa Bella Vista, $10^{\circ} 56 \mathrm{~N}, 63^{\circ} 50^{\prime} \mathrm{W}, 3-4$ m depth (Simone col., 02/ii/1995). 


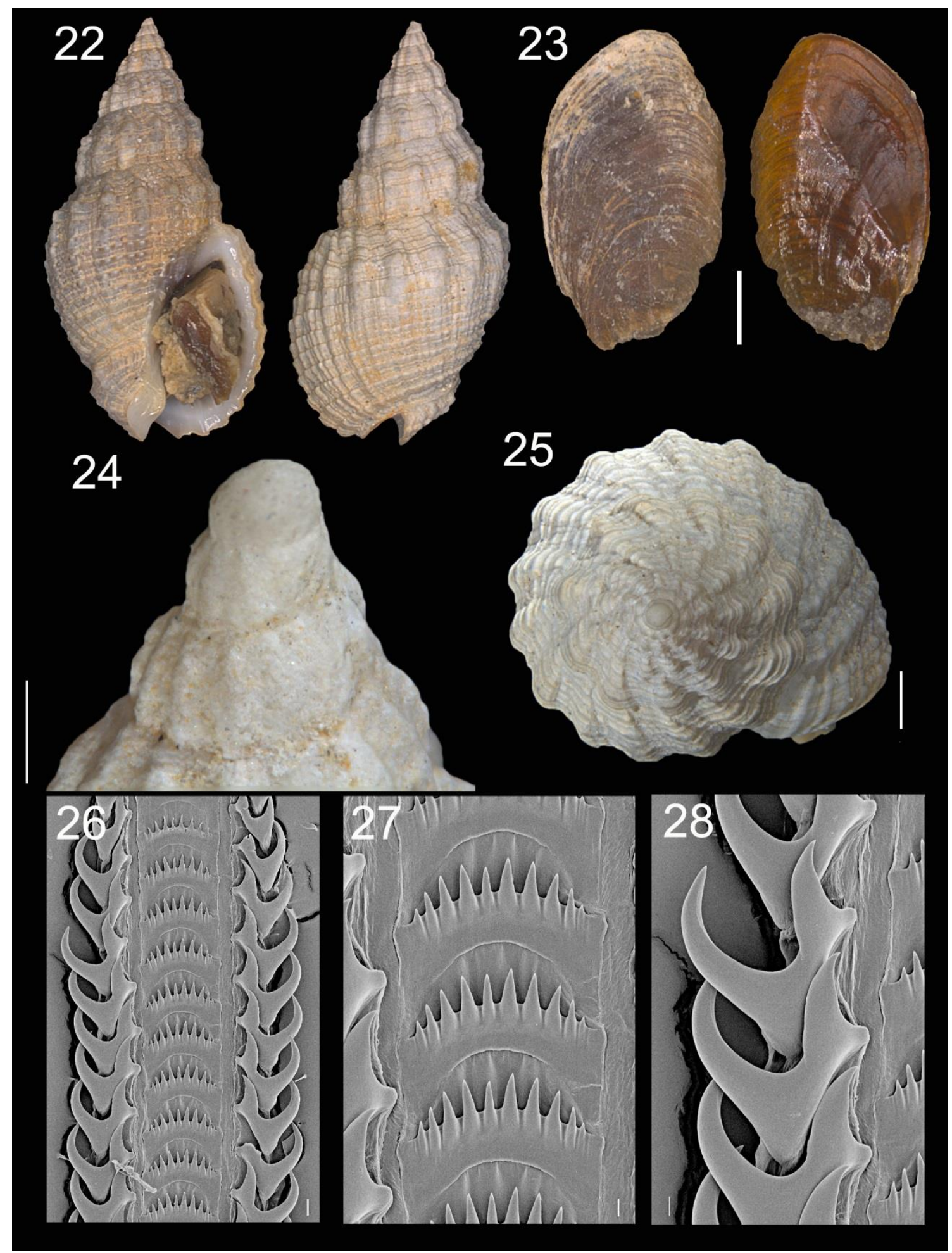

Figs 22-28. Engoniophos unicinctus: MZSP 77798 ๆ, shell, operculum and radula; Figs 22: Shell apertural, and dorsal views (L $18.7 \mathrm{~mm}$ ); Fig. 23: Operculum inner and outer views, scale = $2 \mathrm{~mm}$; Fig. 24: Protoconch and first teleoconch whorls, lateral view, scale $=0.5 \mathrm{~mm}$; Fig. 25: Apical view, scale $=$ 1mm; Fig. 26: SEM of radula: Panoramic view of middle portion, scale $=30 \mu \mathrm{m}$; Fig. 27: same, detail of central teeth, scale $=10 \mu \mathrm{m}$; Fig. 28: same, detail of lateral teeth, scale $=10 \mu \mathrm{m}$. 

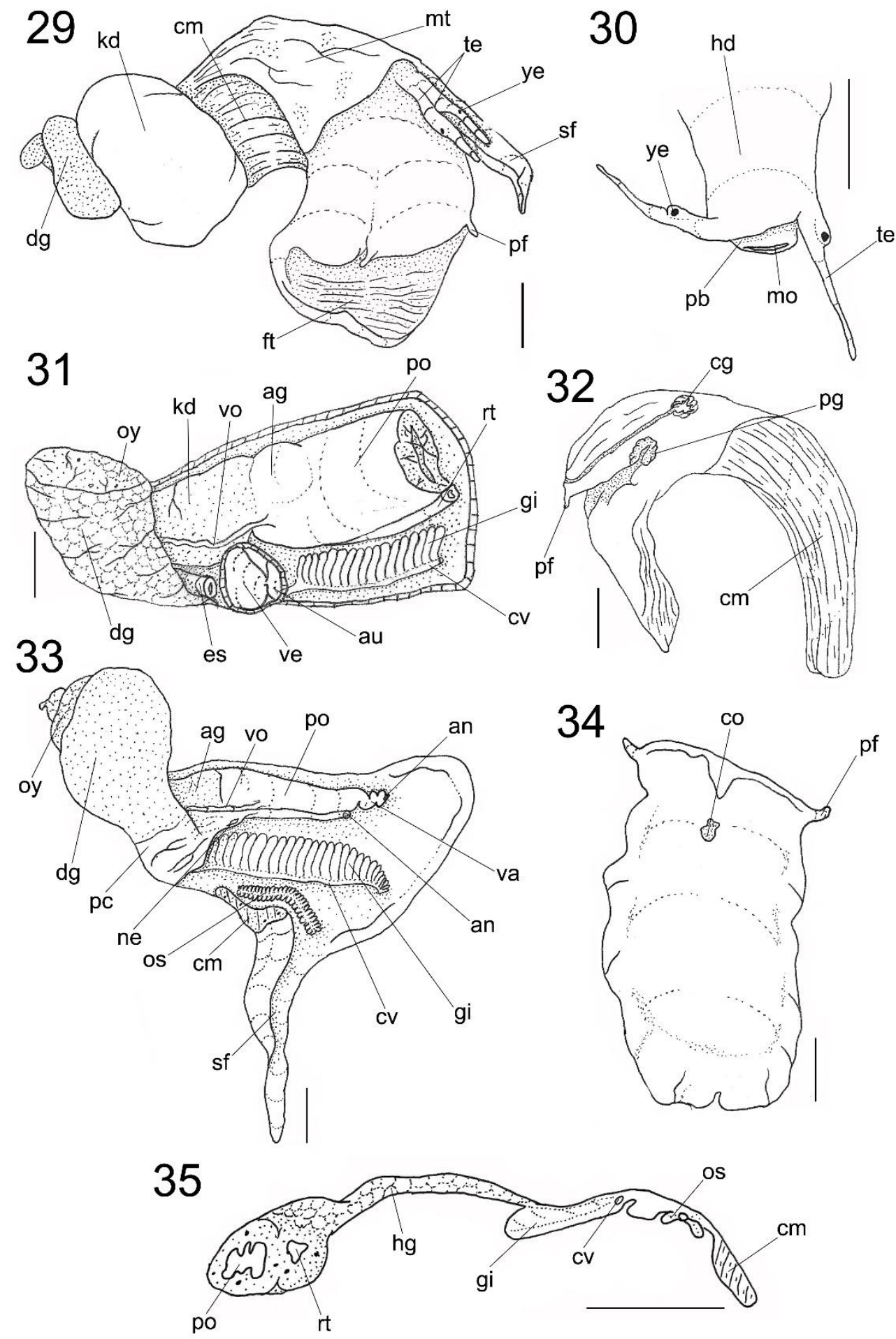

Figs. 29-35. Engoniophos unicinctus: Details of anatomy, Fig. 29: complete specimen extracted from shell (operculum removed), anterior-right view; Fig. 30: Detail of head, dorsal view; Fig. 31: Renopericardial region, ventral view, some adjacent structures also shown; Fig. 32: Foot of female, sagital section; Fig. 33: Pallial cavity roof, ventral view, and coiled visceral mass; Fig. 34: Sole of foot, female, propodial expansions and cement gland opening shown; Fig. 35 Pallial cavity roof, transverse section at middle level of osphradium. Scales $=2 \mathrm{~mm}$. 

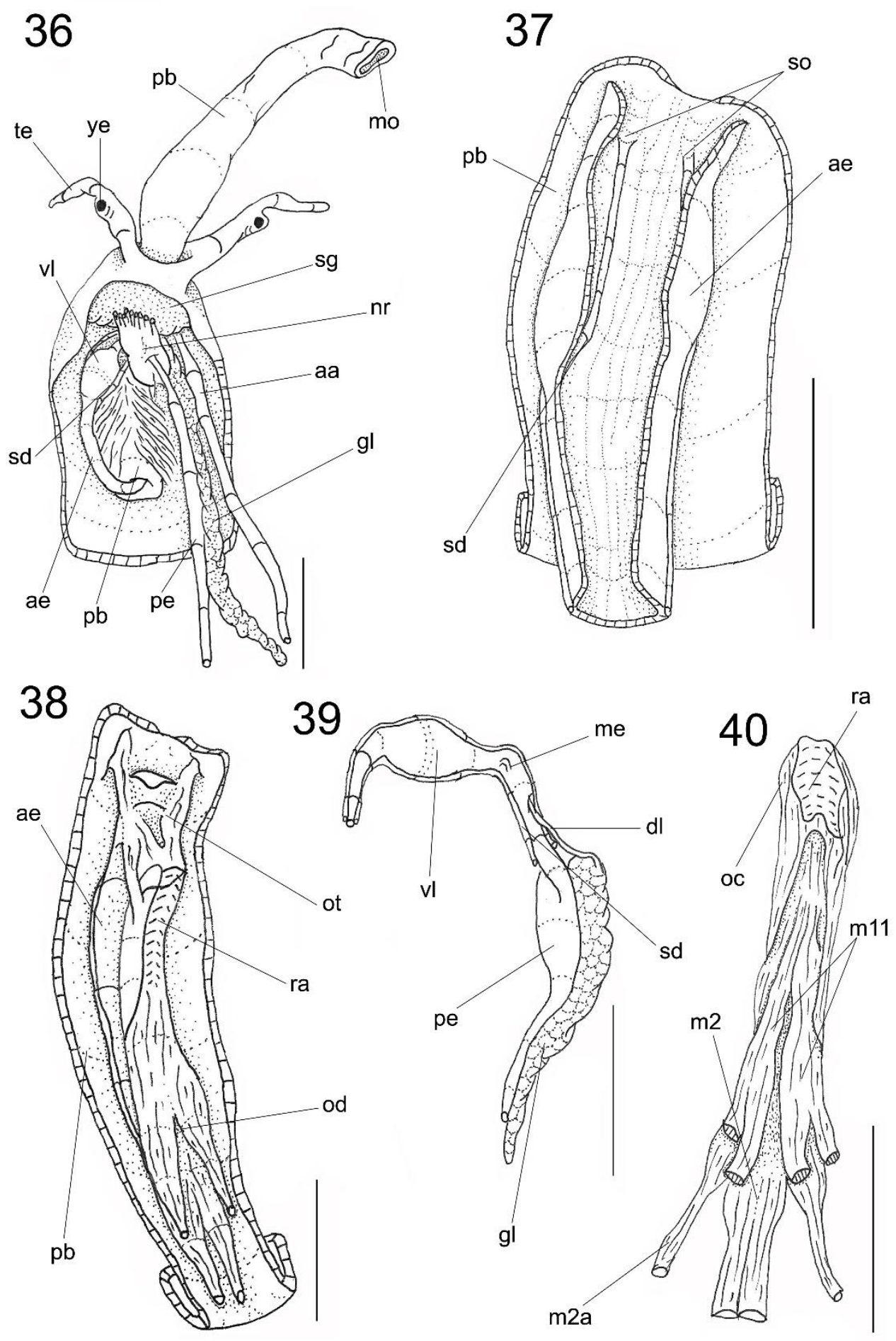

Figs 36-40. Engoniophos unicinctus: Details of anatomy: Fig. 36: Head and haemocoel, ventral view, foot and columellar muscle removed; Fig. 37: Proboscis and anterior esophagus opened longitudinally, showing salivary ducts and their apertures; Fig. 38: Extended proboscis opened longitudinally, ventral view, odontophore as in situ; Fig. 39: Mid and anterior region of posterior esophagus and associated structures, showing valve and gland of Leiblein; Fig. 40: Odontophore, dorsal view, superficial layer of membrane removed. Scales $=2 \mathrm{~mm}$. 

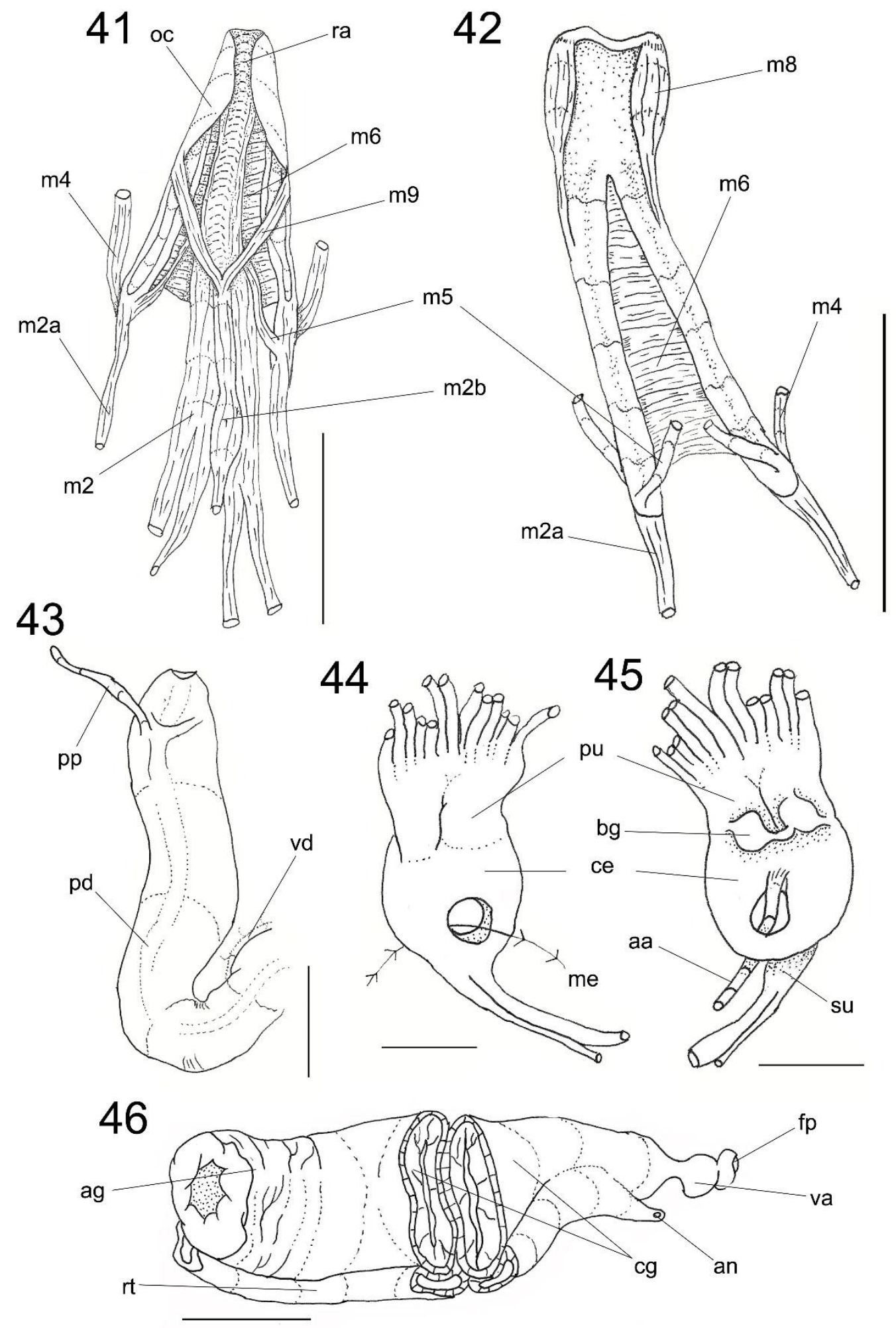

Figs 41-46. Engoniophos unicinctus: Details of anatomy: Fig. 41: Odontophore, dorsal view, superficial muscles dissected; Fig. 42: Odontophore cartilages, dorsal view, some adjacent muscles shown; Fig. 43: Penis, ventral view, penis duct shown by translucency; Figs. 44, 45: Nerve ring, ventral and dorsal views; Fig. 46: Pallial oviduct, ventral view, transversely sectioned in its middle level, some adjacent structures also shown. Scales $=2 \mathrm{~mm}$. 


\section{Genus Demoulia Gray, 1838}

Type species: Buccinum retusum Lamarck, 1822 (type by subsequent designation)

\section{Demoulia abbreviata (Gmelin, 1791).}

Fig. 47-63.

Buccinum abbreviatum Gmelin, 1791 (original combination)

Buccinum cassideum Sowerby I, 1825

Cassis glans Röding, 1798

Nassa (Demoulea) abbreviata (Gmelin, 1791)

Nassa globosa Sowerby I, 1825

Shell (Figs. 47-49). oval, as long as wide, with 6-7 convex whorls, cream. Protoconch wide, smooth, dome-shaped, white, with two whorls; transition uncleaTeleoconch sculpture consisting of 8 thin spiral cords along entire surface on all whorls (twice as many on body whorl); space between cords equals to their width; axial sculpture consisting of a very thin spiral cords crossed entire shell; depression between ribs as wide as ribs themselves. Spire angle $\sim 50^{\circ}$. Aperture elliptical, as long as wide, cream, opaque; length $\sim 1 / 2$ of shell length. Siphonal canal short, broad, dorsally recurved. Anal notch present. Outer lip thin, lirate. Columella straight, without folds.

Head-foot (Figs. 52, 54). Head protruded, socket-like; tentacles separated from each other by space equal than head, short and wide, $\sim 1 / 2$ shorter than head; eyes located on base of tentacle. Rhynchostome as longitudinal slit, located in middle region of ventral surface of head. Foot large, occupying whole body whorl (retracted), bearing pair of small epipodeal tentacles; pedal gland located in central region of foot, forming groove, extending from dorsum of foot (propodium) to sole. Cement gland of females rounded, located in anterior region of mesopodium, inner space wide, duct long (Fig. 32). Cement gland absent. Opercular pad elliptical, $\sim 40 \%$ as wide as dorsal surface of foot; attachment with operculum occupying $\sim 50 \%$ of foot area. Penis originated in right lateral region, posterior to cephalic base, at level of mantle edge. Columellar muscle wide and broad, 1 whorl long. Haemocoel short and broad, extending dorsally along center of foot and columellar muscle.

Operculum (Fig. 50). Small, oval, corneous, pale brown, located close to edge of foot; occupying 1/4 of apertural area. Nucleus terminal, inferior. Outer surface with normal concentric growth lines, forming undulations. Scar oval, occupying $\sim 2 / 3$ of inner surface. 
Mantle organs (Figs. 56, 57). Mantle cavity covering $\sim 1$ whorl. Siphon width $\sim 1 / 2$ of mantle cavity width, length $\sim 2 / 3$ of mantle cavity length. Right base of siphon high, width $\sim$ twice of mantle edge width; left base low. Osphradium short and narrow, elliptical, length $\sim 1 / 4$ of pallial cavity length, width $\sim 1 / 8$ of its width. Osphradial filaments short and sessile, width similar to mantle edge. Ctenidial vein (efferent branchial vessel) with uniformly narrow along its length. Gill elliptic, occupying $~ 90 \%$ of length and $\sim 1 / 5$ of width of pallial cavity. Anterior end of gill rounded, ending gradually, inserted directly into pallial cavity. Gill filaments relatively uniform in size along its entire length. Posterior end of gill rounded, located in posterior region of mantle cavity close to pericardium. Gill filaments height $\sim 1 / 2$ of that of pallial cavity, apex rounded, straight; space between gill and right pallial organs about twice of gill width. Hypobranchial not seen in detail. Right side of pallial cavity almost entirely filled by gonoducts. Rectum long and thin, with $\sim 2 / 3$ of pallial cavity length. Anus pedunculated, closed to the mantle edge. Anal gland absent.

Visceral mass (Figs. 52, 57). Extending $~ 2$ whorls posterior to pallial cavity. Digestive gland dark beige, occupying $~ 80 \%$ of visceral mass, encircling stomach. Gonad orange with small black spots, located on columellar surface, posterior to stomach. Seminal vesicle of males located in anterior portion of gonad, $\sim 1 / 2$ of its size. Kidney occupying $\sim 1 / 3$ of visceral mass volume, located on right side of anterior visceral end. Stomach not seen in detail.

Circulatory and excretory systems (Fig. 56, 57). Reno-pericardial region occupying 1/3 of whorl, oval, on right margin of last whorl of visceral mass, adjacent to mantle cavity. Pericardium occupying $1 / 4$ of reno-pericardial region, posterior to gill; situated on left anterior margin of visceral mass. Auricle reniform, muscular, anterior to ventricle; with three connections: on upper right side with kidney, on anterior right side with gill, and on posterior left side with ventricle. Ventricle four times larger than auricle, with common aorta on left posterior margin. Kidney occupying 1/5 of pallial cavity volume, renal lobe single, divided into chambers, with glandular transverse folds along its ventral surface; efferent renal vessel located at its right portion. Nephridial gland not seen in detail. Nephrostome as small, transverse slit, located in anterior region of membrane between kidney and pallial cavity.

Digestive system (Figs. 53, 55, 57-61). Mouth longitudinal, narrow, located at middle proboscis' tip. Proboscis short, straight and thick, occupying $\sim 80 \%$ of haemocoel. Rhinchodeal wall thick, involving $\sim 2 / 3$ of proboscis. Retractor muscles covering the 
posterior edge of proboscis. Odontophore and buccal mass muscles: $m j$, thick pairs of perioral muscles connected on both sides, dorsal and ventral, surrounding odontophore cartilages; $m 1$, jugal muscles, several small muscle fibers connecting buccal mass to adjacent inner surface of proboscis; $m 2$, strong retractor muscles of buccal mass, originating on inner surface of proboscis, running along entire odontophore, inserting in anterior region of odontophore cartilages; $m 2 a$, absent; $m 2 b ; m 3$, long, $\sim 50 \%$ of odontophore length, cylindrical muscle forming outer wall of odontophore, with transverse fibers; $m 4$, pairs of thin radular dorsal tensor muscles covering almost entire surface of posterior portion of odontophore cartilages, inserting into subradular membrane; $m 5$, pair of auxiliary dorsal tensor muscles of radula, originating inside edges of cartilage, adjacent to insertion of $\mathrm{m} 4 ; m 6$, horizontal muscle, thin, connecting ventral edges of cartilages, running almost along its entire length; $m 8$, not visualized; $m 11$, not seen in detail. Additional odontophore structures: $b r$, subradular membrane, thin, translucent, along entire length of radular ribbon, covering inner surface of odontophore cartilages; $o c$, odontophore cartilages, about 3 times as long as wide, inner ventral surface concave, $\sim 1 / 5$ of anterior end fused with each other, $\sim 1 / 2$ of anterior region, concave, involving radular ribbon; $r s$, radular sac thin-walled, cylindrical, located at posterior end of radula. Radular teeth (Figs. 51): rachidian tooth wide, comb-like, occupying about half of radular width; base curved, width $\sim 4 \times$ its length; $~ 10$ triangular, sharp pointed cusps of similar size, except for some diminishment towards side; lateral tooth hook-like, bicuspid, base broad (equivalent to rachidian base width), obliquely disposed; main lateral cusp widely curved inwards, about as long as base; secondary cusp with rounded end, approximately same size of main lateral cusp. Salivary glands small, located at anterior portion of haemocoel, occupying 1/8 of haemocoel volume, entirely involving nerve ring, middle esophagus and anterior portion of proboscis. Salivary ducts very narrow, except for short proximal region running completely attached to anterior esophagus wall and, more anteriorly, inside dorsal folds of buccal cavity; opening very small, near the mouth in anterior region of buccal cavity. Valve of Leiblein large, about $1 / 8$ of mid-gut volume, located in medium esophagus anterior to nervous ring, anterior region with transverse white band bearing long cilia, middle and posterior regions white, corresponding to inner gland occupying most of inner surface; bypass absent. Gland of Leiblein wide and elongated, twice as long as middle esophagus, becoming gradually narrower posteriorly; duct of gland of Leiblein straight, long and very narrow, length $\sim 1 / 2$ of medium esophagus length, width 1/6 of medium esophagus width. Accessory salivary 
glands absent. Anterior esophagus thin; walls muscular, occupying entire length of proboscis. Middle esophagus slender, short, diameter and length approximately same those of anterior esophagus. Posterior esophagus narrow, except for dilation in the anterior region, straight, about as long as anterior esophagus, differentiation between middle and posterior esophagus clear with a thin duct. Stomach not seen in detail.

Genital system. Male (Fig. 62). Vas deferens narrow, simple, straight, running along ventral surface of kidney up to pallial cavity. Prostate totally closed (tubular), running thought right mantle edge, at $\sim 2 / 3$ of total pallial cavity length. Vas deferens anterior to prostate, straight, running immersed into integument of dorsum, next to mantle border and penis base. Penis large, length $\sim 1 / 2$ of total head-foot length, slender, dorsoventrally flattened; base curved, apical region pointed. Penial duct straight, running through center of penis, closed (tubular). Penial papilla curved, slender, subterminal. Penial aperture apical.

Female (Figs. 56, 57, 63). Visceral oviduct narrow, posterior half sinuous, anterior half straight, running along ventral surface of kidney in first whorl of visceral mass, located in front of pallial cavity. Posterior region of pallial oviduct protruding into kidney, occupying almost entire length of pallial cavity and 1/3 of its width. Albumen gland posterior, small, whitish, thick-walled, occupying 1/5 of pallial oviduct. Capsule gland $\sim 4 / 5$ of oviduct, elongated, orange, thick-walled. Vaginal atrium anterior to capsule gland occupying $~ 1 / 7$ of oviduct; straight, walls thick, muscular, female genital pore narrow, protruded, papilla-like, with thick edges. Bursa copulatrix small, rounded in form of sac, $\sim 1 / 8$ of oviduct length.

Central nervous system. Not analyzed.

Shell measurements (length $x$ width in $\mathrm{mm}$ ): $1 \overbrace{}^{\Uparrow} 26.4 \times 23.1 ; 1 q 29.5 \times 23.1$.

Distribution: Cape of Good Hope to Natal, South Africa.

Habitat: Subtidal to a $100 \mathrm{mt}$ depth.

Material examined: AUSM C478557.001, South Africa: Western Cape, False Bay; 53 m depth (Loch col. 1992). 


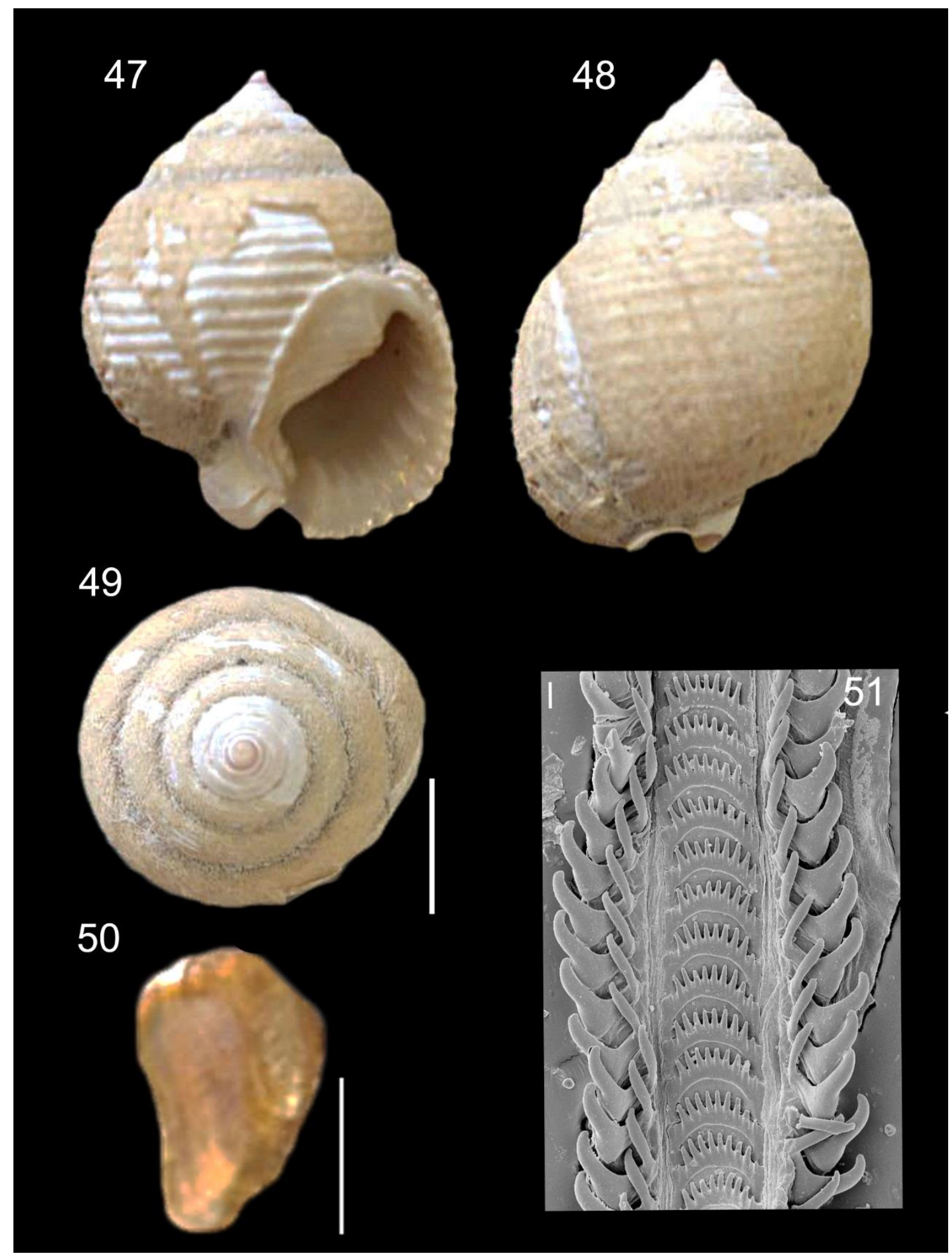

Figs 47-51. Demoulia abbreviata: AUSM: C478557.001, shell, operculum and radula; Figs 47: Shell apertural, Fig. 48: Shell dorsal view (29,5); Fig. 49: Apical view, scale $=1 \mathrm{~mm}$; Fig. 50: Operculum outer view, scale $=2 \mathrm{~mm}$; Fig. 51: SEM of radula: Panoramic view of middle portion, scale $=20 \mu \mathrm{m}$. 

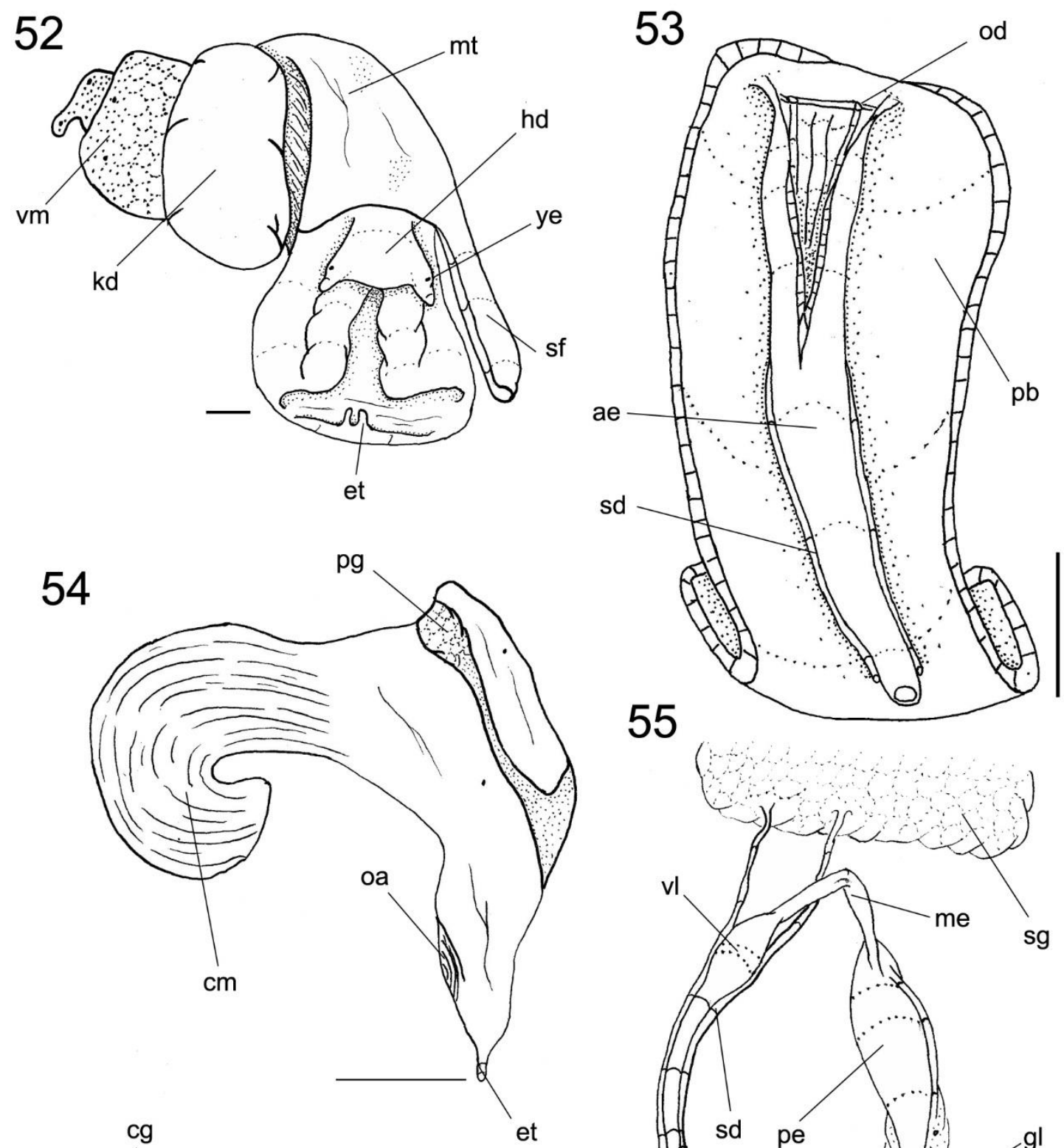

55

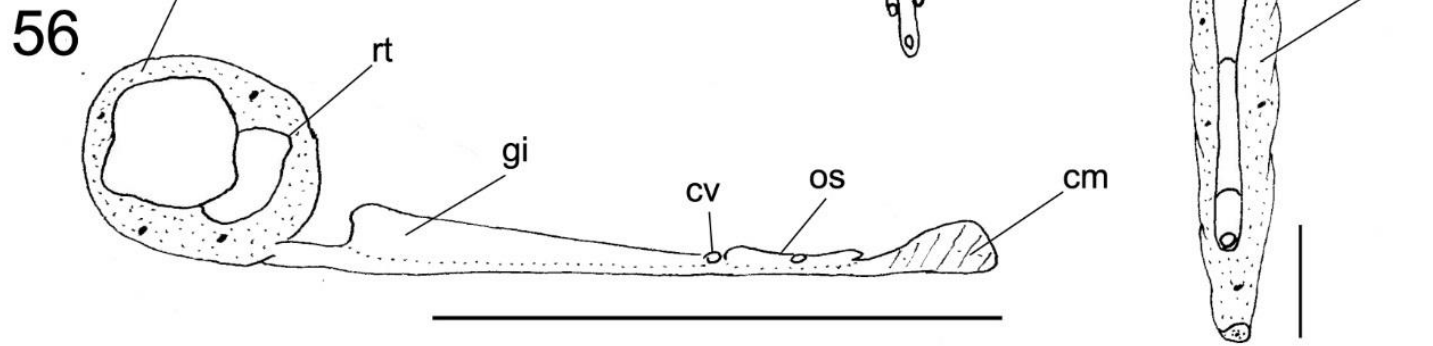

Figs. 52-56. Demoulia abbreviata: Details of anatomy, Fig. 52: complete specimen extracted from shell (operculum removed), anterior-right view; Fig. 53: Proboscis and anterior esophagus opened longitudinally, showing salivary ducts and their apertures; Fig. 54: Foot of female, sagittal section; Fig. 55; Mid and anterior region of posterior esophagus and associated structures, showing valve and gland of Leiblein; Fig. 56: Pallial cavity roof, transverse section at middle level of osphradium. Scales $=2 \mathrm{~mm}$. 


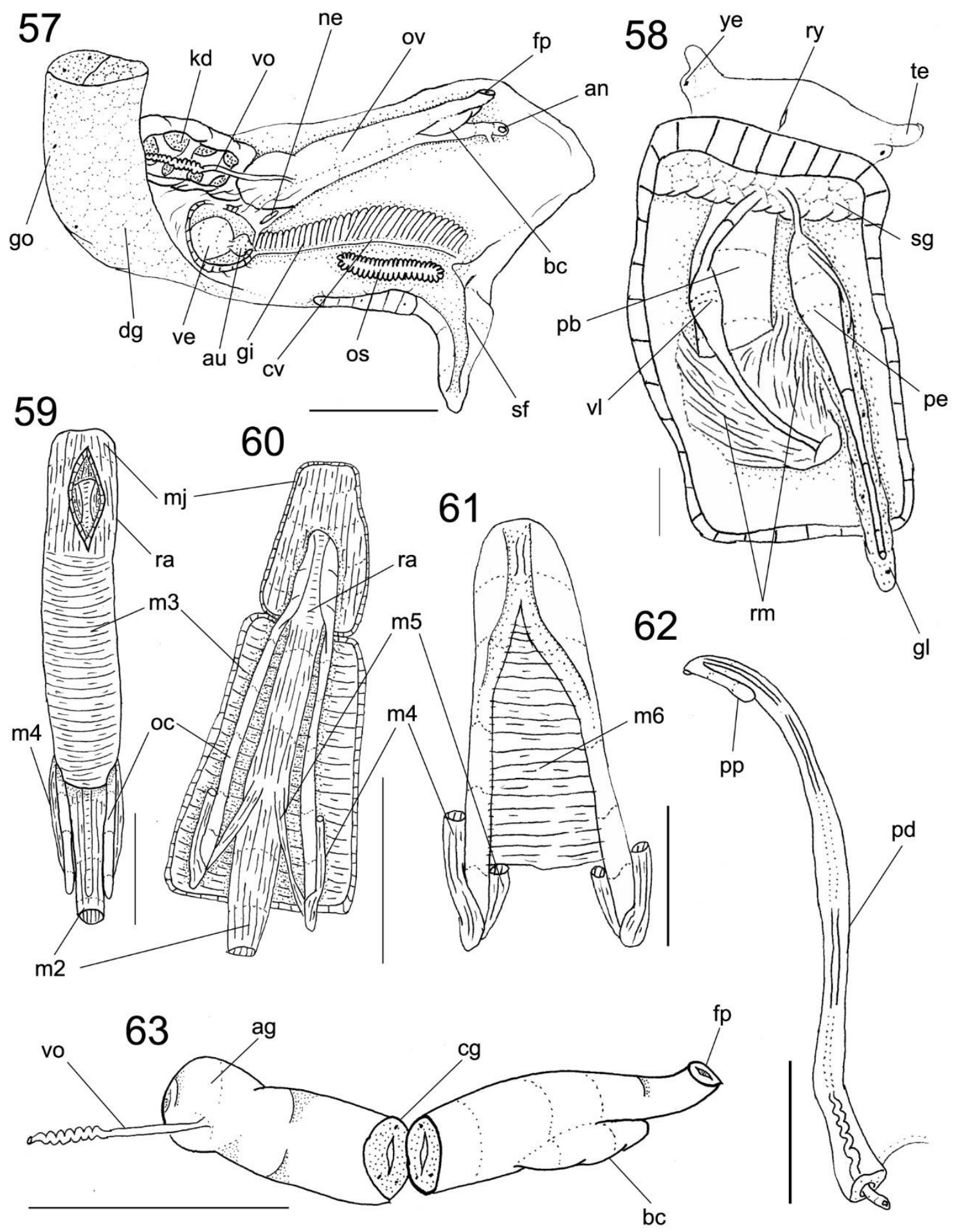

Figs. 57-63. Demoulia abbreviata: Details of anatomy, Fig. 57: Pallial cavity roof, ventral view, and coiled visceral mass; Fig. 58: Head and haemocoel, ventral view, foot and columellar muscle removed; Fig. 59: Odontophore, dorsal view, superficial layers showed; Fig. 60: Odontophore, dorsal view, superficial muscles dissected; Fig. 61: Odontophore cartilages, dorsal view, some adjacent muscles shown; Fig. 62: Penis, ventral view, penis duct shown by translucency; Fig. 63: Pallial and visceral oviduct, ventral view, transversely sectioned in its middle level. Scales $=2 \mathrm{~mm}$. 


\section{Tribe Hinini tribe nov.}

\section{Genus Hinia Gray, 1847}

Type species: Buccinum reticulatum, Linné, 1758 by subs. designation (Cossman, 1901)

\section{Hinia corticata (A. Adams, 1852) comb.nov. Figs. 64-82.}

Vide Cernorhorsky, 1984: Page: 205; plate: 45, figs 10-13.

Shell (Figs. 64-67). Ovate, about 1/4 long as wide, with 7 convex whorls; color light orange to light brown, with amber nodules near the sutures. Protoconch small, smooth, cream, with three whorls; transition to teleoconch hardly indicated by a depression and by the difference of sculpturing. Teleoconch sculpture composed of innumerous cream axial ribs along entire surface and amber spiral nodules of different sizes along all surface os whorls, spire angle $\sim 66^{\circ}$, shoulder absent. Aperture prosocline, rounded, posteriorly acuminate, ca. 1/3 of shell length; color white; outer lip thick, palatal wall smooth; parietal rib present; Parietal shield weakly developed; Anal notch well marked. Siphonal canal short, strong, with four small plicae on the inner surface deep, narrow ( 1/3 of aperture length) and dorsally recurved.

Head-foot (Figs. 70, 72). Pallial cavity covering 1/2 of total animal length; muscular siphon located on left, length $\sim 1 / 3$ of head-foot length. Head protruded; tentacles closed from each other, shorted and broad, $2 \mathrm{x}$ as long as head; eyes pedunculated, located in medium region of tentacles. Foot large, occupying all body whorl (retracted), flat, bearing a pair of long metapodial tentacles; pedal gland located in anterior medium region of foot, forming a groove, extending to dorsum of foot (propodium). Opercular pad occupying $\sim 1 / 8$ of dorsal area of foot, oval. Penis originated in right lateral region, posterior to cephalic base, at level of mantle edge. Columellar muscle small and broad, 1/2 whorl long. Haemocoel long and narrow, extending dorsally along center of foot and columellar muscle, $2 \mathrm{x}$ as long as wide.

Operculum (Fig. 68). Medium size, ovate, horny, pale orange; occupying almost entire aperture. Nucleus terminal, inferior. Outer surface with normal concentric growth lines, forming undulations. Scar elliptical, occupying about $2 / 3$ of inner surface, located close to edge of foot; expansions in the form of spines on both sides, left and right.

Mantle organs (Figs. 75). Mantle cavity covering $~ 1$ whorl. Siphon width 1/5 of mantle cavity width, length $1 / 2$ of mantle cavity length. Right base of siphon high, width about two times as mantle edge width; left base low ending gradually near of anterior region of gill. Osphradium short and broad, elliptical, length 1/4 of pallial cavity length, 
width $\sim 1 / 5$ of its width. Osphradial filaments short, broad. Ctenidial vein (efferent branchial vessel) uniformly narrow along its length. Gill long and thin, rectangular in shape, occupying about half of length and 1/6 of width of pallial cavity. Anterior end of gill rounded, ending gradually, inserted directly into pallial cavity. Gill uniformly narrow along its length., Posterior end with same width of entire gill, inserted into pericardium. Gill filaments low and triangular. Hypobranchial glan not seen in detail. Right side of pallial cavity almost entirely filled by gonoducts. Rectum long and thin, occupying 95 $\%$ of pallial cavity width. Anus simple, distance between anus and mantle border 1/5 of total pallial cavity length. Anal gland absent.

Visceral mass (Figs. 70, 75). About 2 1/2 whorls posterior to mantle cavity. Digestive gland dark beige, occupying $~ 80 \%$ of visceral mass, encircling stomach. Gonad orange with small black spots, located on columellar surface, posterior to stomach. Seminal vesicle of males located in anterior portion of gonad, $\sim 1 / 2$ of its size. Kidney occupying $\sim 1 / 2$ of visceral mass volume, located on right side of anterior visceral end. Stomach not analyzed.

Circulatory and excretory systems (Fig. 74-75). Reno-pericardial region occupying 1 whorl, adjacent to mantle cavity; triangular shaped. Pericardium occupying 1/4 of reno-pericardial region, posterior to gill; situated on left anterior margin of visceral mass. Auricle rounded muscular, anterior to ventricle; with three connections: on upper right side with kidney, on anterior right side with gill, and on posterior left side with ventricle. Ventricle three times as large as auricle, with common aorta in left posterior margin. Kidney small occupying $1 / 6$ of pallial cavity length, renal lobe single, solid; efferent renal vessel located at its right portion. Nephridial gland not seen in detail. Nephrostome small, longitudinal slit, located in anterior region of membrane between kidney and pallial cavity.

Digestive system (Figs. 69, 71, 73, 77-80). Mouth longitudinal, narrow. Proboscis short and broad, occupying about $90 \%$ of haemocoel lenght. Rhynchodeal wall thick and membranous, involving $1 / 3$ of proboscis. Thin retractor muscles covering posterior end of proboscis. Salivary glands located at anterior portion of haemocoel, occupying $\sim 1 / 4$ of haemocoel volume, entirely involving nerve ring, middle esophagus and anterior portion of proboscis. Salivary ducts very narrow, running completely attached to anterior esophagus wall and, more anteriorly, inside dorsal wall of buccal cavity along the folds; opening very small, closed to the mouth. Valve of Leiblein large, about 1/5 of proboscis volume, located in medium esophagus anterior to nervous ring, diameter about $3 \mathrm{x}$ of the 
anterior esophagus, anterior region with transverse white band bearing long cilia, middle and posterior regions white, corresponding to inner gland that occupies most of inner surface. Gland of Leiblein narrow and elongated, 2 x longer than middle esophagus, becoming gradually narrower towards posterior, duct of Gland of Leiblein, long and very narrow. Accessory salivary glands absent. Anterior esophagus thin uniformly narrow along its length; walls muscular, without longitudinal folds, occupying entire length of proboscis. Middle esophagus about two times diameter of anterior esophagus; posterior esophagus $\sim 90 \%$ of total haemocoel lenght, thick, with constant diameter along its entire length, differentiation between middle and posterior esophagus not clear. Stomach and digestive gland ducts not analyzed in detail.

Odontophore and buccal mass muscles: $m j$, thick of perioral muscles connected on both sides, dorsal and ventral, surrounding odontophore cartilages, short, about 1/5 of odontophore length,; $m 1$, jugal muscles, several tinny and thin fibers which connected odontophore in proboscis wall; $m 2$, pair of two strong protractor muscles of buccal mass, originating on inner surface of proboscis, running along entire odontophore, inserting in anterior region of odontophore cartilages; $m 2 a$, absent; $m 2 b$, absent; $m 3$, long and cylindrical muscle forming outer wall of odontophore, with longitudinal fibers; $m 4$, pairs of strong radular dorsal tensor muscles covering almost entire dorsal surface of posterior portion of odontophore cartilages, originating outside edges of cartilage and inserting into subradular membrane; $m 5$, pair of auxiliary dorsal tensor muscles of radula, originating inside edges of cartilage, adjacent to $\mathrm{m} 4$ insertion; $m 6$, horizontal muscle, thick, connecting ventral edges of cartilages, running through almost entire length of cartilages; $m 8$, pair of elliptical muscles, $\sim 1 / 4$ of total length of odontophore, originating at anterior dorsal end of odontophore cartilages, running along ventral surface of odontophore, inserting on anterior ventral surface of cartilages; $m 11$, not visualized. Additional odontophore structures: $b r$, subradular membrane, thin, strong and translucent, along entire length of radular ribbon, covering inner surface of odontophore cartilages; $o c$, odontophore cartilages, about $3 x$ long as wide, inner ventral surface concave, $\sim 1 / 4$ of anterior end fused with each other; $r s$, radular sac thin-walled, cylindrical, located at posterior end of radula; $n r$, radular nucleus width $\sim 1 / 2$ of radular sac width.

Radular teeth (Fig. 69). Rachidian tooth wide, comb-like, occupying about 1/3 of radular width; base curved, width $\sim 3 \times$ its length; 20 triangular, sharp pointed cusps of similar size, except for some diminishment towards the side; lateral tooth hook-like, with two cusps, base broad with expansion toward to rachidian tooth, obliquely disposed; main 
lateral cusp widely curved inwards, about as long as base; secondary cusp approximately the same size of main lateral cusp; radula ribbon equal between males and females; jaws absent

Genital system. Male (Fig. 76). Vas deferens narrow, simple, straight, running along ventral surface of kidney up to pallial cavity. Prostate totally closed (tubular), running thought right mantle edge, at $\sim 1 / 3$ of total pallial cavity length. Vas deferens anterior to prostate, straight, running immersed into integument of dorsum, next to mantle border and penis base. Penis slender, length $\sim 2 / 4$ of total head-foot length, dorso-ventrally flattened and with wide point at the base; base curved, apical region dilated. Penial duct straight, running through center of penis, closed (tubular). Penial aperture distal, small, without papilla.

Female (Figs. 75, 81). Visceral oviduct narrow, straight, running along dorsal surface of kidney in first whorl of visceral mass, located in front of pallial cavity. Posterior region of pallial oviduct protruding into kidney, occupying $~ 1 / 3$ of length of pallial cavity and 1/7 of its width. Albumen gland posterior, whitish, thick-walled, occupying 1/5 of pallial oviduct. Capsule gland $\sim 2 / 3$ of oviduct, elongated, orange, thick-walled. Female pore like a vaginal slit at dorsal surface of oviduct, occupying 1/5 of oviduct; walls thick, muscular. Bursa copulatrix absent. Cement gland absent.

Central nervous system (Figs. 82). Nerve ring located in ventral anterior proboscis region, occupying $\sim 1 / 12$ of haemocoel volume, highly concentrated. Ganglia mostly fused, hard to distinguish from each other, symmetrical. Pairs of pleural and cerebral ganglia fully fused with each other. Sub-esophageal not seen in detail. Esophageal aperture small, central, located in midlle region of cerebral ganglia, occupying about 1/10 of surface of nerve ring. Pair os small statocysts located in antero-ventral region of pleural ganglia.

Shell measurements (length $x$ width in $\mathrm{mm}$ ): $1 \hat{\jmath} 13.4$ x 8.27; 1 1 13.7 x 8.19.

Distribution: India, Philippines to Solomon Islands.

Habitat: under rocks, near river mouth and among mangroves

Material examined: AUSM C478568; Solomon Islands, West Cost of Malaita Island; Aoki Harbour, 9m depth (P.H Colman col. 18/viii/1973). 


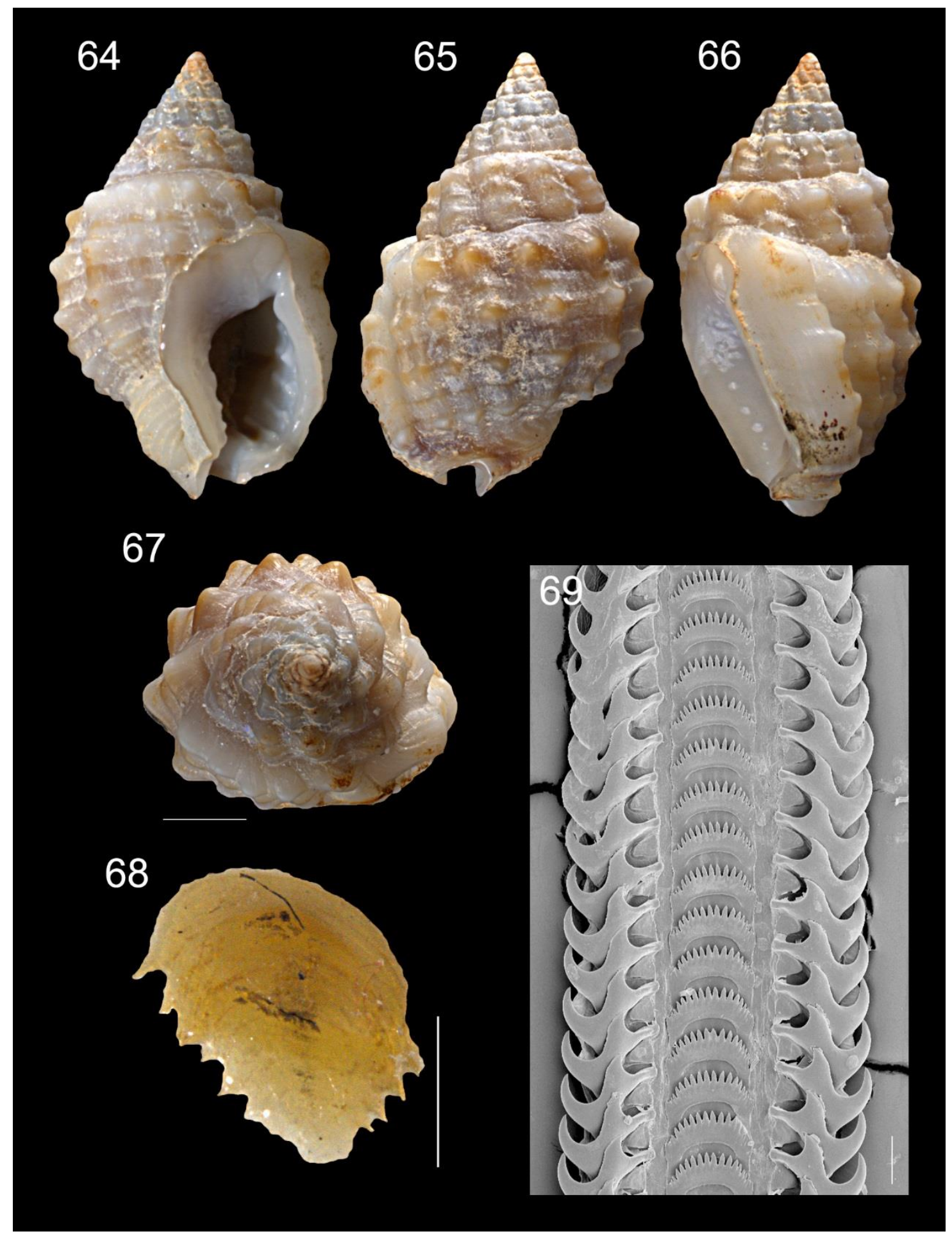

Figs. 64-69. Hinia corticata: AUS: 78568, shell, operculum and radula; Figs. 64: Shell apertural view, (L 13,4 mm); Fig. 65: Shell dorsal view (L 13,4 mm); Fig. 66: lateral view; Fig. 67: Apical view, scale $=2 \mathrm{~mm}$; Fig. 68: Operculum outer view, scale $=2 \mathrm{~mm}$; Fig. 69: SEM of radula: Panoramic view of middle portion, scale $=20 \mu \mathrm{m}$. 


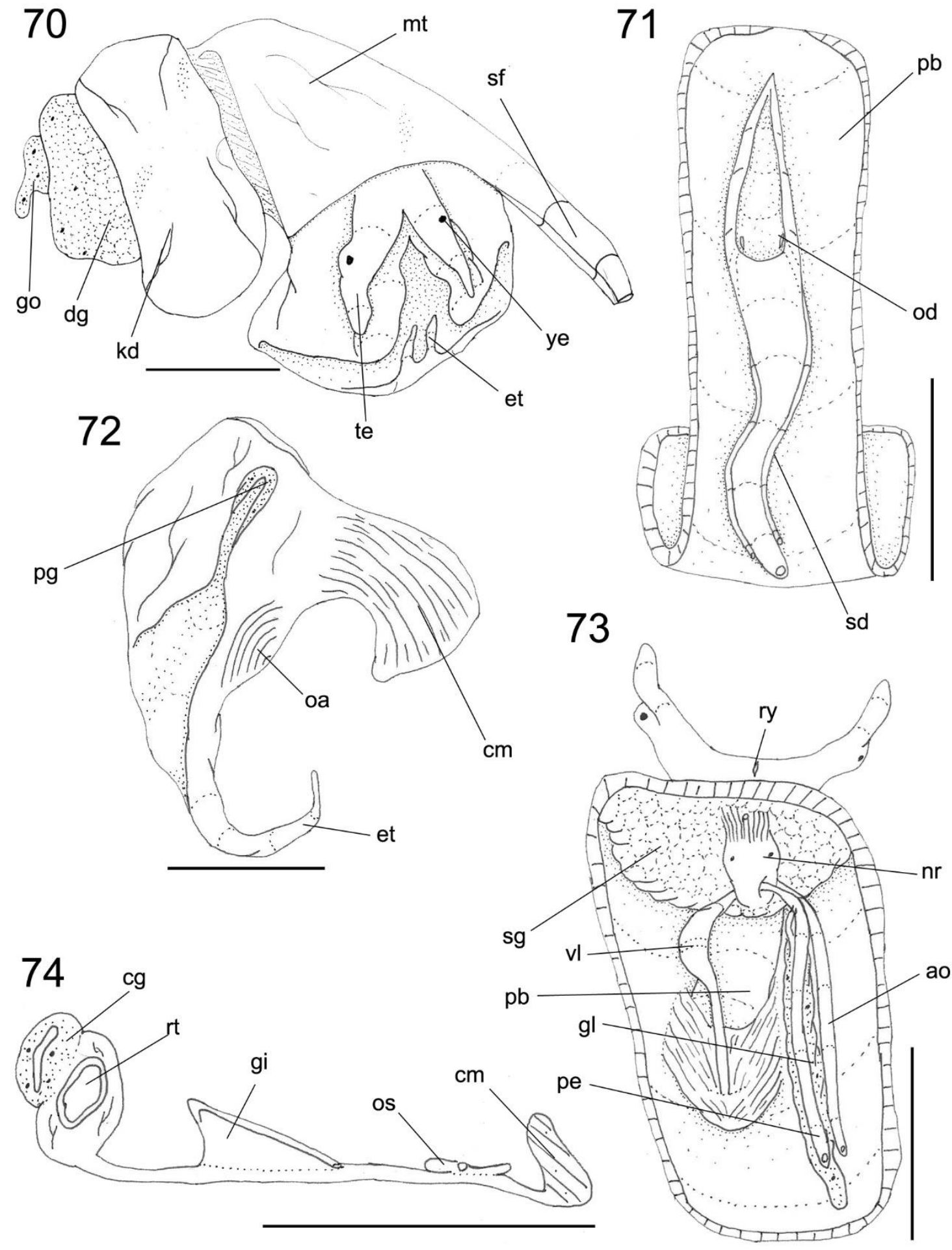

Figs. 70-74. Hinia corticata: Details of anatomy, Fig. 70: complete specimen extracted from shell (operculum removed), anterior-right view; Fig. 71: Proboscis and anterior esophagus opened longitudinally, showing salivary ducts and their apertures; Fig. 72: Foot of female, sagittal section; Fig. 73 Head and haemocoel, ventral view, foot and columellar muscle removed; Fig. 74: Pallial cavity roof, transverse section at middle level of osphradium. Scales $=2 \mathrm{~mm}$. 


\section{5}

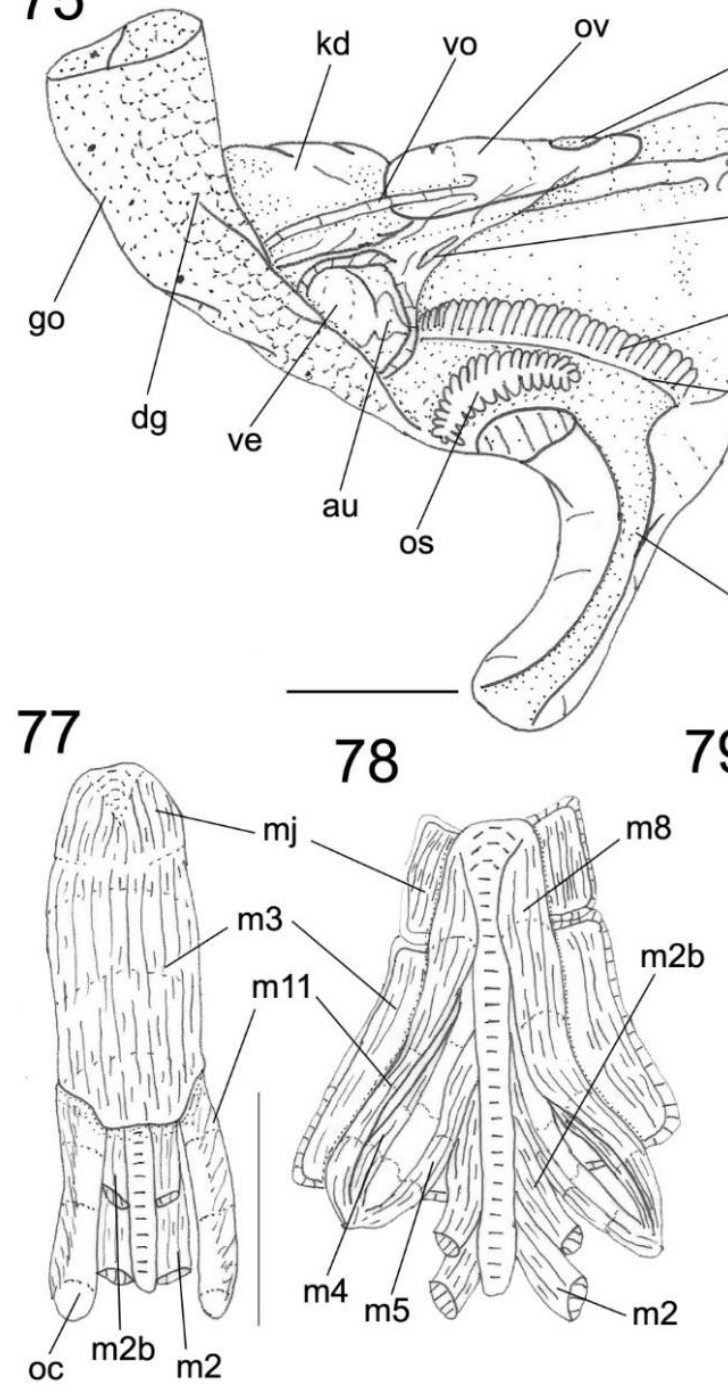

fp

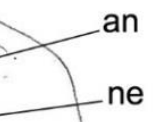

go

(1)
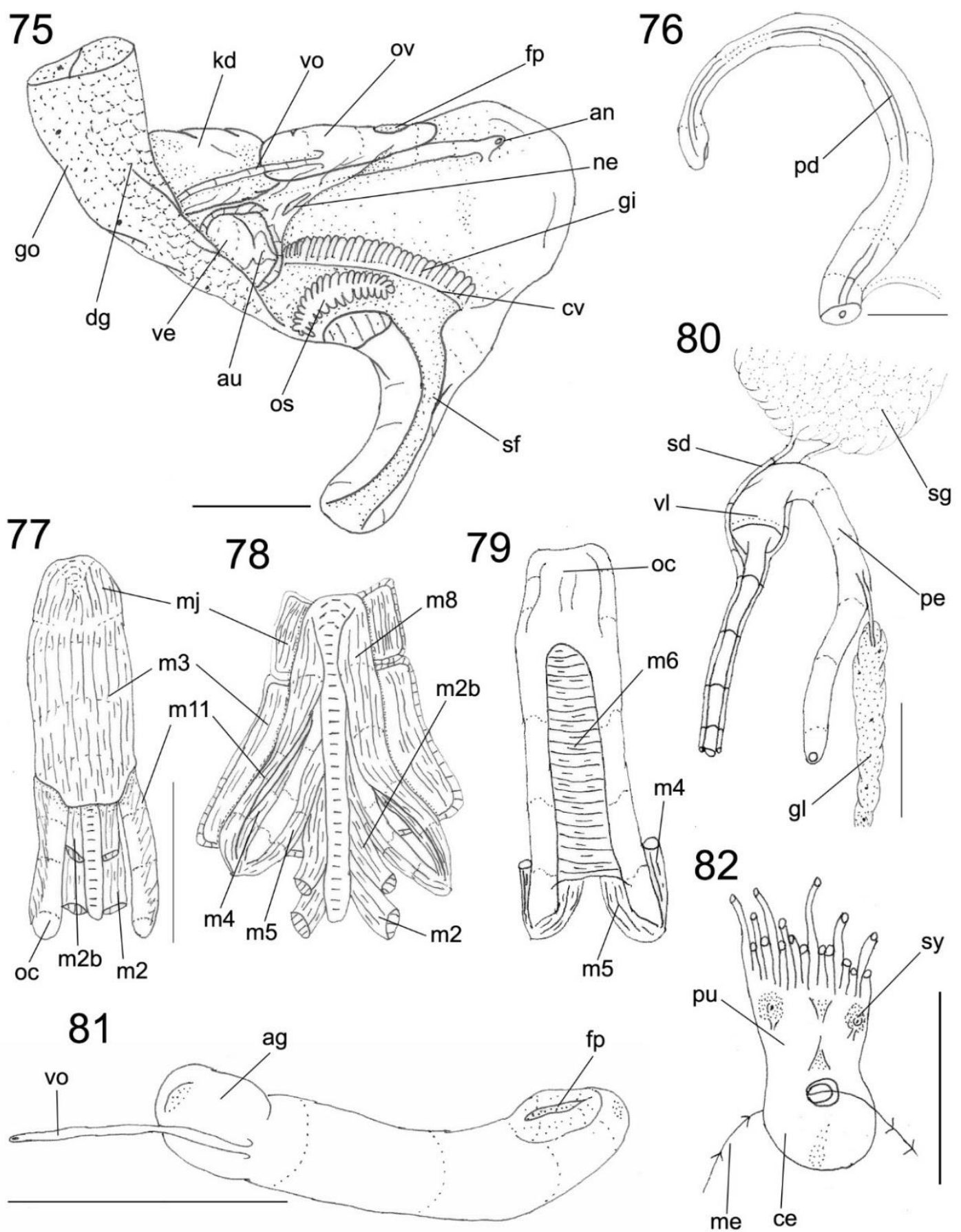

80

79
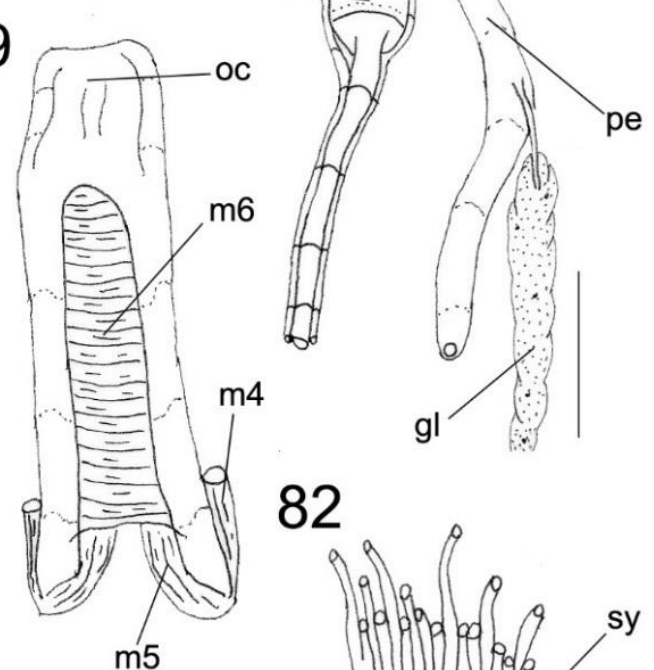

\section{2}

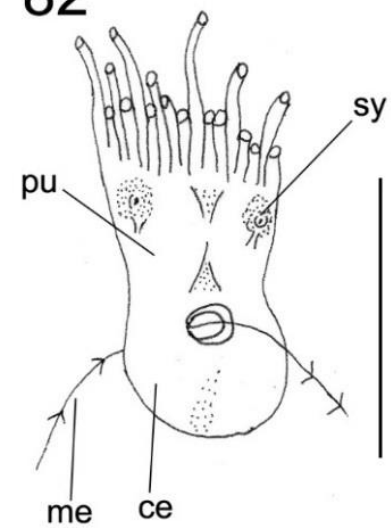

Figs. 75-81. Hinia corticata: Details of anatomy, Fig. 75: Pallial cavity roof, ventral view, and coiled visceral mass; Fig. 76: Penis, ventral view, penis duct shown by translucency; Fig. 77: Odontophore, dorsal view, superficial layers showed; Fig. 78: Odontophore, dorsal view, superficial muscles dissected; Fig. 79: Odontophore cartilages, dorsal view, some adjacent muscles shown; Fig. 80: Mid and anterior region of posterior esophagus and associated structures, showing valve and gland of Leiblein; Fig. 81. Pallial and visceral oviduct, ventral view; Fig. 82: Nerve ring, ventral view, statocysts also showed. Scales $=2 \mathrm{~mm}$. 


\section{Hinia reticulata comb. nov. \\ Figs. 83-99.}

Buccinum reticulatum Linné, 1758:10 (740) (original combination)).

Nassarius reticulatus (Linné, 1758)

Buccinum anglicum Röding, 1798

Buccinum chrysostomum Röding, 1798

Buccinum marginulatum Lamarck, 1822

Buccinum porcatum Röding, 1798

Buccinum vulgatum Gmelin, 1791

Hinia reticulata (Linné, 1758)

Nassa (Hinia) reticulata (Linnaeus, 1758)

Nassa (Hinia) reticulata var. viriditincta Dautzenberg \& Fischer H., 1925

Nassa bourguignati Locard, 1887

Nassa cancellata Martens, 1870

Nassa coronata Nobre, 1884

Nassa isomera Locard, 1886

Nassa limicola Martens, 1870

Nassa oblonga Mörch, 1852 dubious synonym

Nassa poirieri Locard, 1887

Nassarius reticulatus Cernohorsky, 1984: 52; Rolan E. \& Luque A.A., 1995: 59-76.

Shell (Figs. 83, 84). Ovate, about twice long as wide, with 5 convex whorls; color beige to brown for all over shell surface. Protoconch big, smooth, light beige, with about $21 / 2$ whorls; transition to teleoconch hardly indicated by a depression and by the difference of sculpturing. Teleoconch sculpture composed of light beige ribs along entire surface and dark beige spiral nodules near the sutures, spire angle $\sim 55^{\circ}$, shoulder absent. Aperture prosocline, rounded, posteriorly acuminate, ca. 1/2 of shell length; color white with; outer lip thick, palatal wall smooth; parietal rib weakly present; Parietal shield medially developed, covering about 1/4 of ventral surface of body whorl; Anal notch weakly marked. Siphonal canal short, strong, deep, narrow ( 1/3 of aperture length) and dorsally recurved.

Head-foot (Figs. 87, 91). Pallial cavity with 1 whorl; muscular siphon located on left, length $\sim 1 / 3$ of head-foot length. Head protruded; tentacles closed from each other, elongated and narrow, 3x as long as head; eyes pedunculated, located in medium region of tentacles. Foot big, occupying almost entire body whorl (retracted), flat, bearing a pair of medium metapodial tentacles; pedal gland located in anterior edge of foot, forming a groove, extending to dorsum of foot (propodium). Opercular pad occupying $~ 1 / 8$ of dorsal area of foot, oval. Penis originated in right lateral region, posterior to cephalic base, 
at level of mantle edge. Columellar muscle small and broad, 1 whorl long. Haemocoel long and thin, extending dorsally along center of foot and columellar muscle, 2x as long as wide.

Operculum (Fig. 85). Medium size, ovate, horny, pale orange; occupying almost entire aperture. Nucleus terminal, inferior. Outer surface with normal concentric growth lines, forming undulations. Scar elliptical, occupying about $2 / 3$ of inner surface, located close to edge of foot.

Mantle organs (Figs. 89, 90). Mantle cavity covering 1 whorl. Siphon width 1/4 of mantle cavity width, long, length 1/2 of mantle cavity length. Right base of siphon low, width about two times as mantle edge width; left base low ending gradually. Osphradium short and wide, elliptical, length 1/5 of pallial cavity length, width $\sim 1 / 5$ of its width. Osphradial filaments short, broad. Ctenidial vein (efferent branchial vessel) uniformly narrow along its length. Gill long and wide, occupying 1/2 of length and 1/3 of width of pallial cavity. Anterior end of gill rounded, ending gradually, inserted directly into pallial cavity. Gill filaments increasing in size in middle region. Posterior end of gill tapered, located in posterior region of mantle cavity, inserted into pericardium. Gill filaments low and rounded. Right side of pallial cavity almost entirely filled by gonoducts. Rectum long and thin, occupying $\sim 2 / 3$ of pallial cavity width. Anus pedunculated, distance between anus and mantle border $1 / 4$ of total pallial cavity length. Anal gland absent.

Visceral mass (Figs. 89). About 2 whorls posterior to mantle cavity. Digestive gland dark beige, occupying $\sim 80 \%$ of visceral mass, encircling stomach. Gonad orange with small black spots, located on columellar surface, posterior to stomach. Seminal vesicle of males located in anterior portion of gonad, $\sim 1 / 2$ of its size. Kidney occupying $\sim 1 / 2$ of visceral mass volume, located on right side of anterior visceral end. Stomach small, located half whorl in front of pallial cavity.

Circulatory and excretory systems (Fig. 89, 90). Reno-pericardial region occupying 1 whorl, adjacent to mantle cavity; square shaped. Pericardium occupying 1/4 of reno-pericardial region, posterior to gill; situated on left anterior margin of visceral mass. Auricle rounded muscular, anterior to ventricle; with three connections: on upper right side with kidney, on anterior right side with gill, and on posterior left side with ventricle. Ventricle four times as large as auricle, with common aorta in left posterior margin. Aorta thin, located along postero-left region of ventricle, anterior aorta with twice diameter of posterior aorta. Kidney occupying $1 / 2$ of pallial cavity length, renal lobe single, divided into chambers; efferent renal vessel located at its right portion. Nephridial 
gland not seen in detail. Nephrostome small, longitudinal slit, located in anterior region of membrane between kidney and pallial cavity.

Digestive system (Figs. 88, 92, 93-97). Mouth longitudinal, narrow. Proboscis long and thin, occupying about $90 \%$ of haemocoel lenght. Rhynchodeal wall thin and membranous, involving $2 / 3$ of proboscis. Thick retractor muscles covering posterior end of proboscis. Salivary glands located at anterior portion of haemocoel, occupying $\sim 1 / 5$ of haemocoel volume, entirely involving nerve ring, middle esophagus and anterior portion of proboscis. Salivary ducts very narrow, running completely attached to anterior esophagus wall and, more anteriorly, inside dorsal wall of buccal cavity along the folds; opening very small, closed to the mouth. Valve of Leiblein medium, about 1/8 of proboscis volume, located in medium esophagus anterior to nervous ring, diameter about $1 / 5 \mathrm{x}$ of the medium esophagus, anterior region with transverse white band bearing long cilia, middle and posterior regions white, corresponding to inner gland that occupies most of inner surface. Gland of Leiblein broad and short, $~ 2 \mathrm{x}$ longer than middle esophagus, duct of Gland of Leiblein, short and narrow. Accessory salivary glands absent. Anterior esophagus thin uniformly narrow along its length; walls muscular, with two strong internal longitudinal folds, occupying entire length of proboscis. Middle esophagus with the same diameter of anterior esophagus; posterior esophagus $\sim 90 \%$ of total haemocoel lenght, thin, with constant diameter along its entire length, differentiation between middle and posterior esophagus not clear. Stomach and digestive gland ducts not analyzed in detail.

Odontophore and buccal mass muscles: $m j$, thick of perioral muscles connected on both sides, dorsal and ventral, surrounding odontophore cartilages long, about half of odontophore length; $m 1$, jugal muscles, several tinny and thin fibers which connected odontophore in proboscis wall; $m 2$, pair of strong protractor muscles of buccal mass, originating on inner surface of proboscis, running along entire odontophore, inserting in anterior region of odontophore cartilages; $m 2 a$, absent; $m 2 b$, absent; $m 3$, long and cylindrical muscle forming outer wall of odontophore, with transverse fibers; $m 4$, pairs of strong radular dorsal tensor muscles covering almost entire surface of posterior portion of odontophore cartilages, originating outside edges of cartilage and inserting into subradular membrane; $m 5$, pair of auxiliary dorsal tensor muscles of radula, originating inside edges of cartilage, adjacent to $\mathrm{m} 4$ insertion; $m 6$, horizontal muscle, thick, connecting ventral edges of cartilages, running $~ 2 / 3$ of their length; $m 8$, pair of elliptical muscles, $\sim 1 / 4$ of total length of odontophore, originating at anterior end of odontophore 
cartilages, running along ventral surface of odontophore, inserting on anterior ventral surface of cartilages; $m 11$, pair of ventral tensor muscles of radula, about $1 / 3$ of total odontophore length, originating at ventral-posterior end of cartilages, crossing ventrally entire odontophore, inserting into ventral posterior surface of radula. Additional odontophore structures: $b r$, subradular membrane, thin, strong and translucent, along entire length of radular ribbon, covering inner surface of odontophore cartilages; $o c$, odontophore cartilages, about $3 x$ long as wide, inner ventral surface concave, $\sim 1 / 5$ of anterior end fused with each other; $r s$, radular sac thin-walled, cylindrical, located at posterior end of radula; $n r$, radular nucleus width $\sim 1 / 2$ of radular sac width.

Radular teeth (Fig. 86). Rachidian tooth wide, comb-like, occupying about half of radular width; base curved, width $\sim 3 \times$ its length; $~ 10$ triangular, sharp pointed cusps of similar size, except for some diminishment towards the side; lateral tooth hook-like, with two cusps, base broad (equivalent to rachidian base width), obliquely disposed; main lateral cusp widely curved inwards, about as long as base; secondary cusp approximately 3/4 size of main lateral cusp; radula ribbon equal between males and females.

Genital system. Male. Not analized.

Female (Figs. 89, 90, 99). Visceral oviduct narrow, straight, running along dorsal surface of kidney in first whorl of visceral mass, located in front of pallial cavity. Posterior region of pallial oviduct protruding into kidney, occupying $~ 2 / 3$ of length of pallial cavity and 1/5 of its width. Albumen gland posterior, whitish, thin-walled, occupying $~ 1 / 3$ of pallial oviduct. Capsule gland $\sim 2 / 3$ of oviduct, elongated, orange, thick-walled. Vaginal atrium thin, tubular, occupying 1/6 of oviduct; walls thick, muscular, female genital pore narrow. Bursa copulatrix absent. Cement gland absent.

Central nervous system (Fig.98). Nerve ring located in ventral anterior proboscis region, occupying $\sim 1 / 12$ of haemocoel volume, highly concentrated. Ganglia mostly fused, hard to distinguish from each other, somewhat asymmetrical. Pairs of pleural and cerebral ganglia fully fused with each other. Sub-esophageal ganglia located in middle region of cerebropleural ganglia. Esophageal aperture small, central, located in middle region of pedal and cerebral ganglia, occupying about 1/6 of surface of nerve ring. Statocysts located in ventral surface of pedal ganglia. 
Shell measurements (length $x$ width in $\mathrm{mm}$ ): 2 2 21,13 x 11,31; 22,11 x 12,29.

Distribution: Baltic sea, Mediterranean Sea, North Atlantic Sea

Habitat: Fine sand bottoms, infratidal.

Material examined: MZSP 92087; 2 , , Portugal, Aveiro, Ria de Aveiro (Jardim col. 2009). 


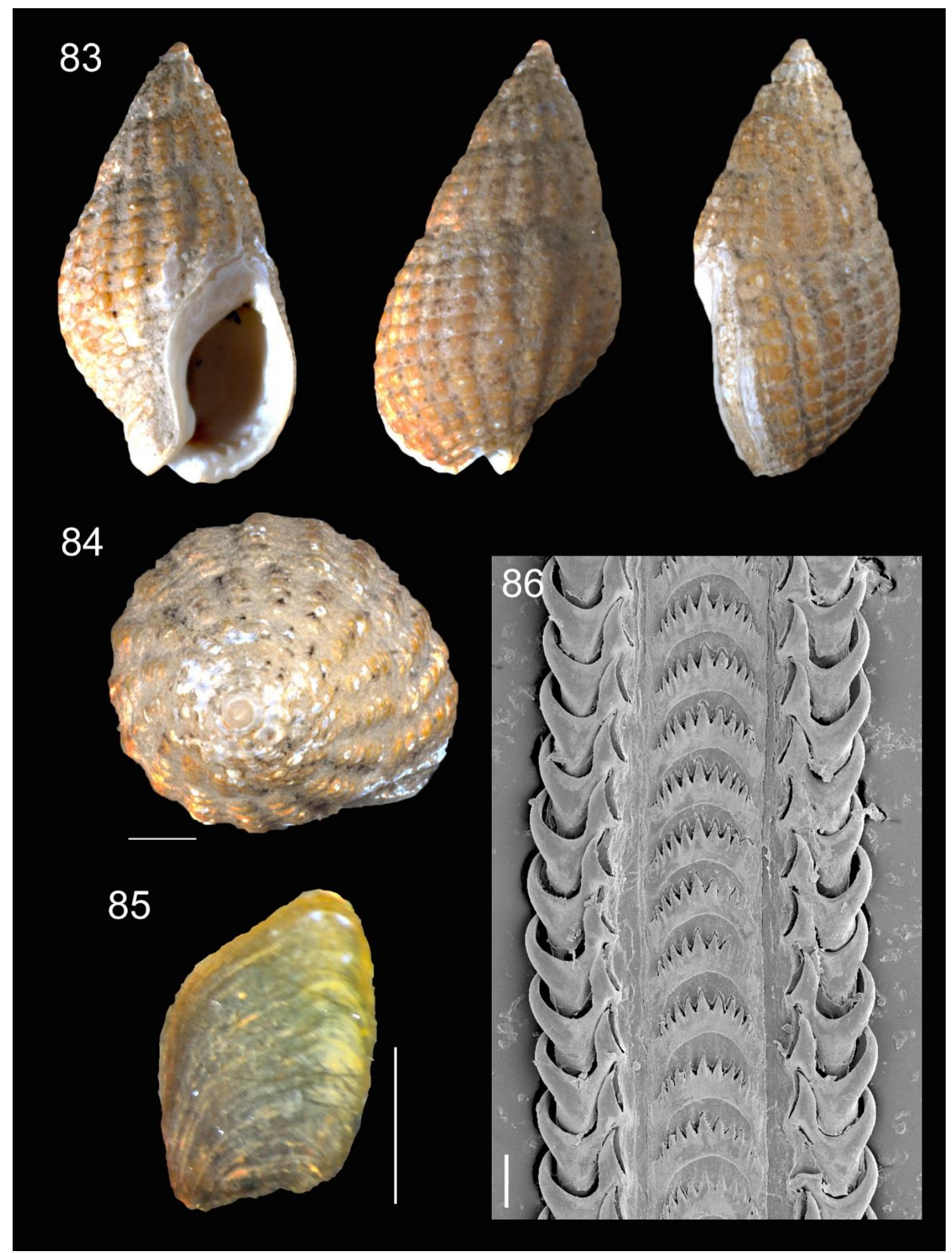

Figs. 83-86. Hinia reticulata: MZSP 92087오, shell, operculum and radula; Figs 83: Adult specimen, Shell apertural, dorsal and lateral view (L 21,13 mm); Fig. 84: shell apical view; Fig. 85: Operculum dorsal view, scale $=2$ mm; Fig. 86; SEM of radula: Panoramic view of middle portion, scale = $30 \mu \mathrm{m}$. 


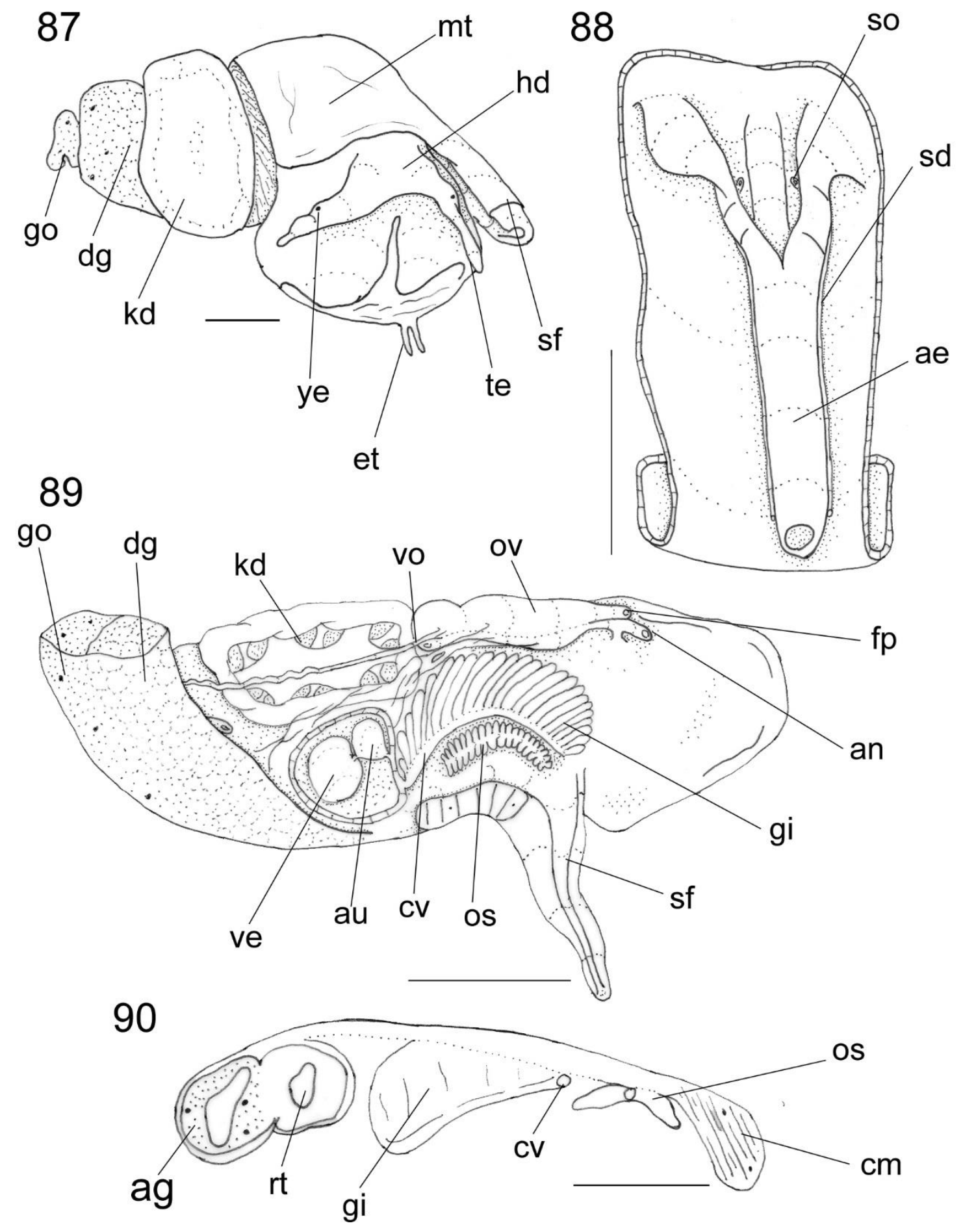

Figs. 87-90. Hinia reticulata: Details of anatomy, Fig. 87: complete specimen extracted from shell (operculum removed), anterior-right view; Fig. 88: Proboscis and anterior esophagus opened longitudinally, showing salivary ducts and their apertures; Fig. 89: Pallial cavity roof, ventral view; Fig. 90: Pallial cavity roof, transverse section at middle level of osphradium. Scales $=2 \mathrm{~mm}$. 

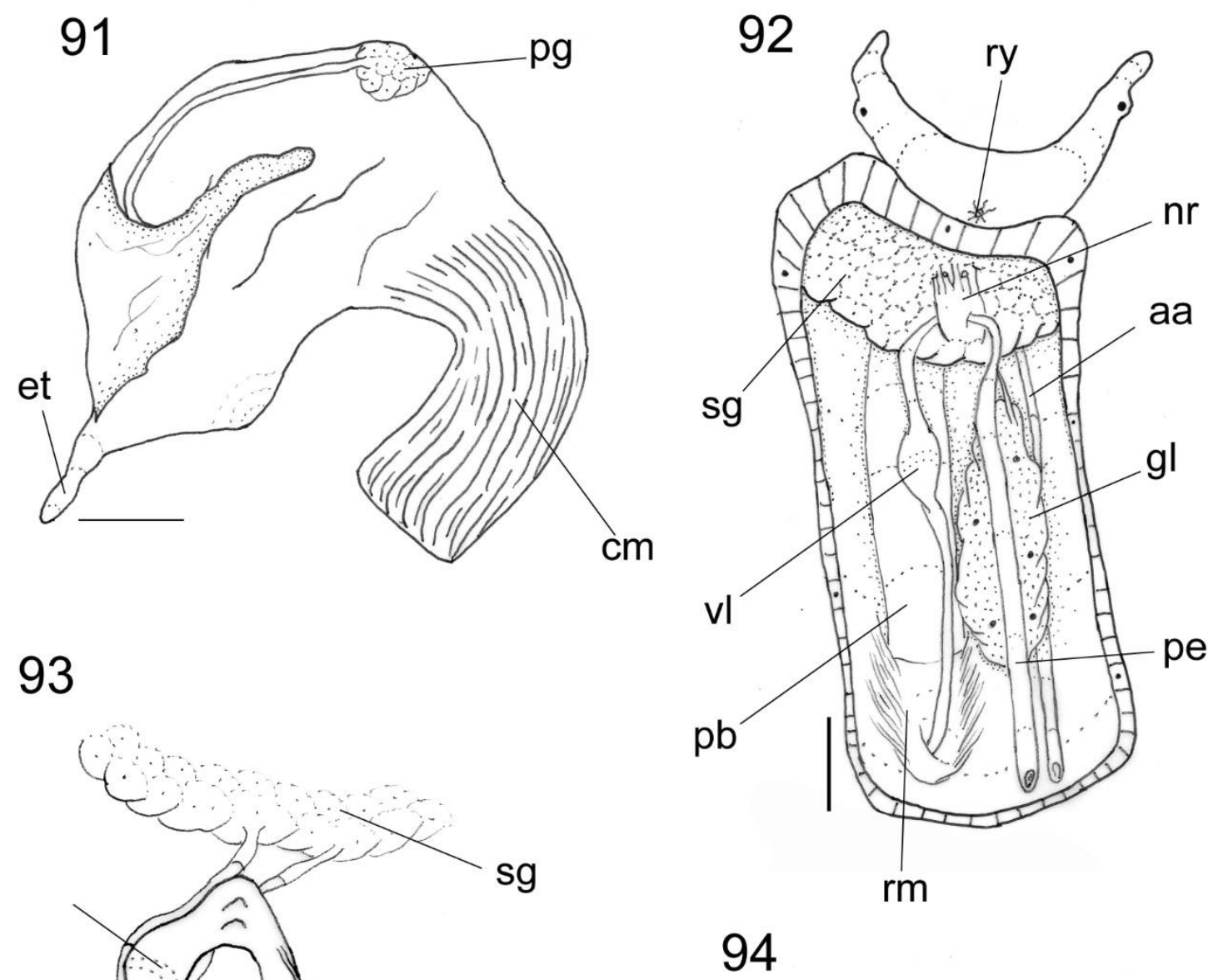

93
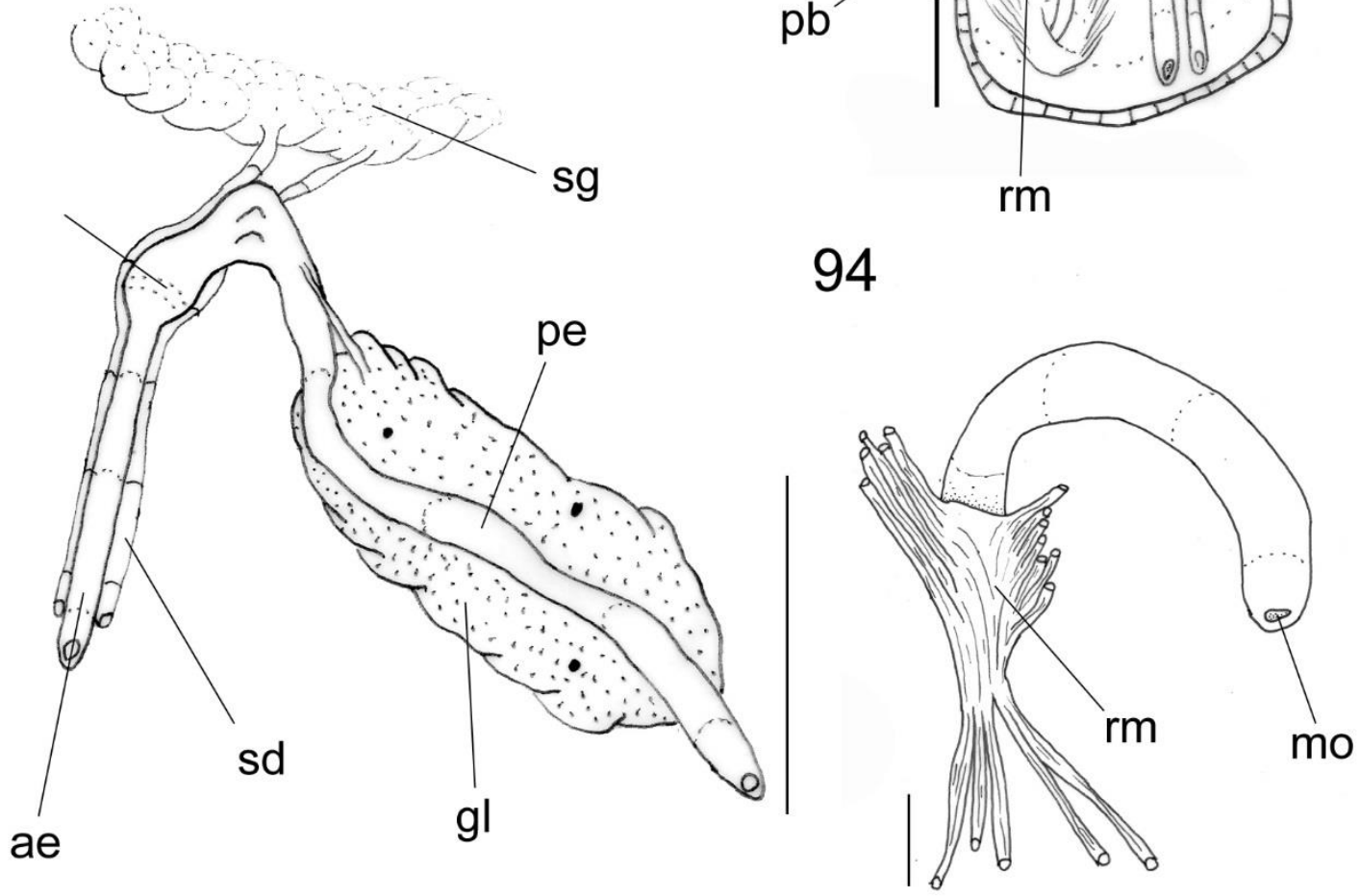

Figs. 91-94. Hinia reticulata: Details of anatomy, Fig. 91: Foot of female, sagittal section; Fig. 92: Head and haemocoel, ventral view, foot and columellar muscle removed; Fig. 93: Detail of fore and midgut, associated structures also shown; Fig. 94: Proboscis, lateral right view. Scales $=2 \mathrm{~mm}$. 

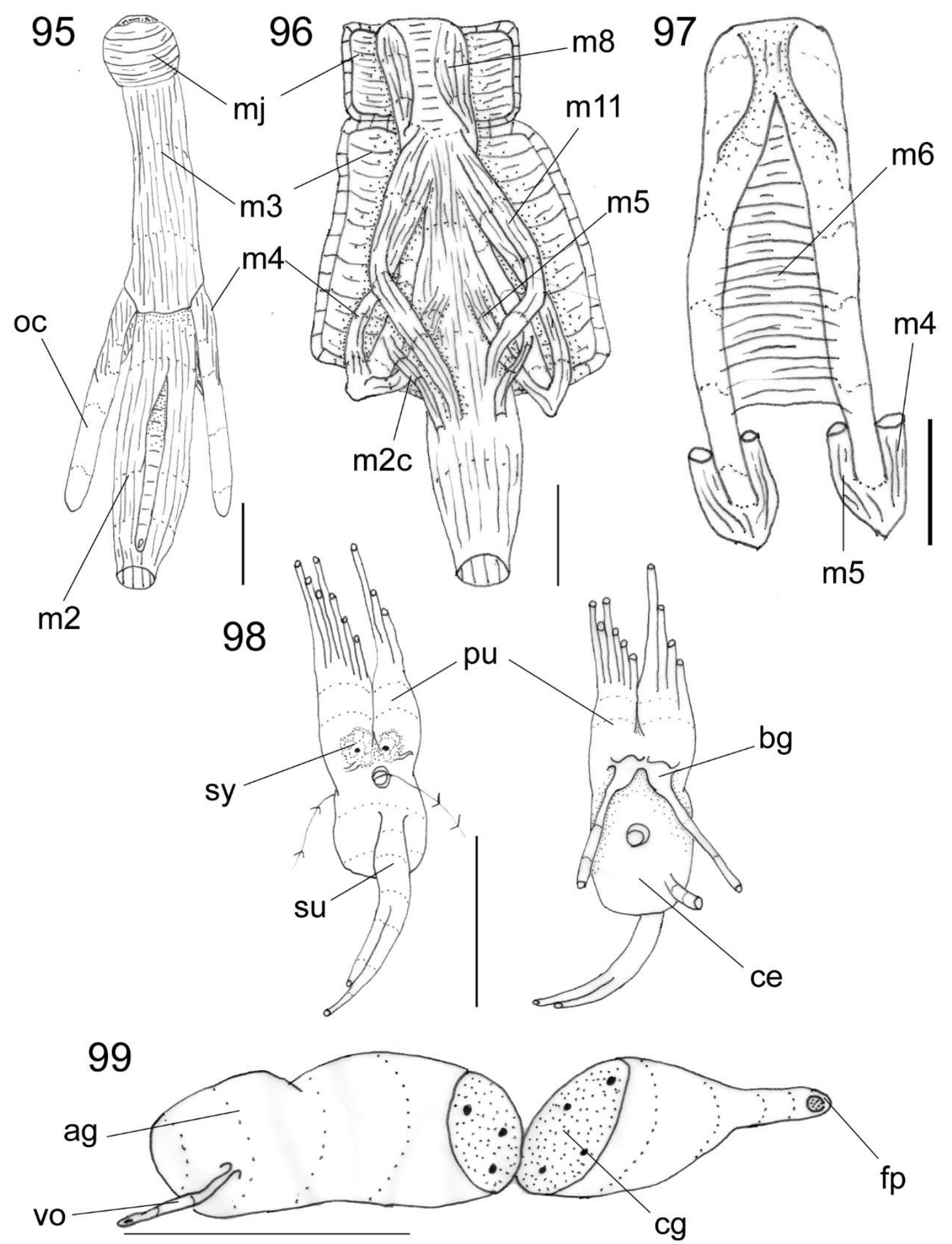

Figs. 95-99. Hinia reticulata: Details of anatomy, Fig. 95: Odontophore, dorsal view, superficial layers showed; Fig. 96: Odontophore, dorsal view, superficial muscles dissected; Fig. 97: Odontophore cartilages, associated muscles shown; Fig. 98: Nerve ring, ventral and dorsal views; Fig. 99: Pallial oviduct, right lateral view. Scales $=2 \mathrm{~mm}$. 


\section{Hinia pulla (Linnaeus, 1758) comb. Nov. \\ Figs. 100-111.}

see Cernohorsky 1984: (pg. 70, pl. 237-238). Complement:

Nassarius pullus Cernohorsky 1984: (pg. 70, pl. 237-238).

Shell (Figs. 100, 101). Ovate, about twice long as wide, with 7 convex whorls; color dark green, with brow bands in the middle region of whorls. Protoconch eroded, apparently small, smooth, brow, with about two whorls; transition to teleoconch indicated by a depression and by the difference of sculpturing. Teleoconch in general eroded, about 1,5 whorls, sculpture eroded, spire angle $\sim 45^{\circ}$, shoulder absent. Aperture prosocline, rounded, posteriorly acuminate, ca. $2 / 3$ of shell length; color white with cream outer band; outer lip thick, palatal wall smooth; parietal rib present; Parietal shield developed, covering ventral surface of body whorl; Anal notch well marked. Siphonal canal short, strong, deep, narrow ( 1/5 of aperture length) and dorsally recurved.

Head-foot (Figs. 103). Pallial cavity covering 1/2 of total animal length; muscular siphon located on left, length $\sim 1 / 3$ of head-foot length. Head inconspicuous; tentacles bases closed from each other, elongated and narrow; eyes simple, located in medium region of tentacles. Foot big, occupying all body whorl cavity (retracted), flat, bearing a pair of medium metapodial tentacles; pedal gland located in anterior edge of foot (Fig.), forming a groove, extending to dorsum of foot (propodium). Opercular pad occupying $\sim 1 / 5$ of dorsal area of foot, oval. Penis originated in right lateral region, posterior to cephalic base, at level of mantle edge. Columellar muscle short and broad, 1/2 whorl long. Haemocoel long and broad, extending dorsally along center of foot and columellar muscle, 1,5x as long as wide (Fig.).

Operculum (Fig. 102). small, ovate, horny, pale orange; occupying about $1 / 2$ of aperture. Nucleus terminal, inferior. Outer surface with normal concentric growth lines, forming undulations. Scar elliptical, occupying all inner surface; lateral expansions absent.

Mantle organs (Figs. 105, 106). Mantle cavity covering 1 whorl. Siphon large, width $1 / 3$ of mantle cavity width, length $1 / 3$ of mantle cavity length. Right base of siphon high, width about two times as mantle edge width; left base high ending gradually. Osphradium long and thin, elliptical, length $1 / 3$ of pallial cavity length, width $\sim 1 / 7$ of its width. Osphradial filaments short, broad. Ctenidial vein (efferent branchial vessel) uniformly narrow along its length. Gill long and wide, occupying 95\% of length and 1/4 of width of pallial cavity. Anterior end of gill rounded, inserted directly into pallial cavity. 
Gill filaments increasing in size in middle and posterior region. Posterior end of gill rounded, located in posterior region of mantle cavity, inserted into pericardium. Gill filaments low and rounded. Hypobranchial gland not seen in detail. Right side of pallial cavity almost entirely filled by gonoducts. Rectum long and broad, Anus siphoned, distance between anus and mantle border 1/4 of total pallial cavity length. Anal gland absent.

Visceral mass (Fig. 105). About 2 whorls posterior to mantle cavity. Digestive gland dark beige, occupying $\sim 1 / 2$ of visceral mass, encircling stomach. Gonad orange with small black spots, located on columellar surface. Male seminal vesicle not seen in detail. Kidney big, occupying $~ 1 / 2$ of visceral mass volume, located on right side of anterior visceral end. Stomach not visualized.

Circulatory and excretory systems (Fig. 105, 106). Reno-pericardial region occupying 1 whorl, adjacent to mantle cavity; oval shaped. Pericardium occupying 1/4 of reno-pericardial region, posterior to gill; situated on left anterior margin of visceral mass. Auricle rounded muscular, anterior to ventricle; with three connections: on upper right side with kidney, on anterior right side with gill, and on posterior left side with ventricle. Ventricle four times as large as auricle, with common aorta in left posterior margin. (Fig.). Kidney occupying $1 / 3$ of pallial cavity length, renal lobe single, with glandular transverse folds along its ventral surface; efferent renal vessel located at its right portion. Nephridial gland not seen in detail. Nephrostome small, transversal slit, located in anterior region of membrane between kidney and pallial cavity.

Digestive system (Figs. 104, 107, 108, 111-113). Mouth transversal, narrow. Proboscis of medium size and broad, occupying about $2 / 3$ of haemocoel length. Rhynchodeal wall thick and muscular, involving $1 / 2$ of proboscis. Thick retractor muscles covering posterior end of proboscis. Salivary glands located at anterior portion of haemocoel, occupying $~ 1 / 6$ of haemocoel volume, entirely involving nerve ring, middle esophagus and anterior portion of proboscis. Salivary ducts very narrow, running completely attached to anterior esophagus wall and, more anteriorly, inside dorsal wall of buccal cavity; opening very small, close to the anterior esophagus openning. Valve of Leiblein medium, about $1 / 8$ of proboscis volume, located in medium esophagus anterior to nervous ring, diameter about $3 \mathrm{x}$ of the medium esophagus, anterior region with transverse white band bearing long cilia, middle and posterior regions white, corresponding to inner gland that occupies most of inner surface. Gland of Leiblein narrow and elongated, $\sim 2 \mathrm{x}$ longer than middle esophagus, becoming gradually narrower 
towards posterior, duct of Gland of Leiblein, long and narrow, $~ 1 / 3$ of gland of Leiblein length. Accessory salivary glands absent. Anterior esophagus thin uniformly narrow along its length; walls muscular, without folds, occupying entire length of proboscis. Middle esophagus with the same diameter of anterior esophagus; posterior esophagus $\sim 90 \%$ of total haemocoel lenght, thin, with constant diameter along its entire length, differentiation between middle and posterior esophagus not clear. Stomach and digestive gland ducts not analyzed in detail.

Odontophore and buccal mass muscles: $m j$, hypertrophied, thick of perioral muscles connected on both sides, dorsal and ventral, surrounding odontophore cartilages, about $1 / 3$ of odontophore length,; $m 1$, jugal muscles, several tinny and thin fibers which connected odontophore in proboscis wall; $m 2$, two pairs of strong protractor muscles of buccal mass, originating on inner surface of proboscis, running along entire odontophore, inserting in anterior region of odontophore cartilages; $m 2 a$, pair of retractor muscles of buccal mass, originating on dorsal surface of haemocoel, inserting at end of posterior margin of odontophore cartilages; $m 2 b$, absent; $m 3$, long and cylindrical muscle forming outer wall of odontophore, with transverse fibers; $m 4$, pairs of strong radular dorsal tensor muscles covering almost entire surface of posterior portion of odontophore cartilages, originating outside edges of cartilage and inserting into subradular membrane; $m 5$, pair of auxiliary dorsal tensor muscles of radula, originating inside edges of cartilage, adjacent to $\mathrm{m} 4$ insertion; $m 6$, horizontal muscle, thick, connecting ventral edges of cartilages, running $\sim 2 / 3$ of their length; $m 8$, pair of elliptical muscles, $\sim 1 / 5$ of total length of odontophore, originating at anterior end of odontophore cartilages, running along ventral surface of odontophore, inserting on anterior ventral surface of cartilages. Additional odontophore structures: $b r$, subradular membrane, thin, strong and translucent, along entire length of radular ribbon, covering inner surface of odontophore cartilages; $o c$, odontophore cartilages, about $2 \mathrm{x}$ long as wide, inner ventral surface concave, $\sim 1 / 4$ of anterior end fused with each other; rs, radular sac thin-walled, cylindrical, located at posterior end of radula; $n r$, radular nucleus width $\sim 1 / 2$ of radular sac width.

Radular teeth. Not visualized.

Genital system. Male (Fig. 110). Vas deferens narrow, simple, straight, running along ventral surface of kidney up to pallial cavity. Prostate totally closed (tubular), running thought right mantle edge, at $\sim 1 / 4$ of total pallial cavity length. Vas deferens anterior to prostate, straight, running immersed into integument of dorsum, next to mantle border and penis base. Penis long, slender, length $\sim 1 / 2$ of total head-foot length, dorso- 
ventrally flattened and with wide point at anterior end; base curved, apical region tapered. Penial duct straight, running through center of penis, closed (tubular). Penial aperture distal, small.

Female (Figs. 105, 106, 109). Visceral oviduct narrow, sinuous, running along dorsal surface of kidney in first whorl of visceral mass, located in front of pallial cavity. Posterior region of pallial oviduct protruding into kidney, occupying $\sim 1 / 2$ of length of pallial cavity and 1/4 of its width. Albumen gland posterior, whitish, thick-walled, occupying $\sim 1 / 3$ of pallial oviduct. Capsule gland $\sim 2 / 3$ of oviduct, elongated, orange, thick-walled. Vaginal atrium broad, tubular, conical, occupying $~ 1 / 8$ of oviduct; walls thick, muscular, female genital pore narrow. Bursa copulatrix present in anterior region of oviduct, about $1 / 4$ of its length. Cement gland absent.

Central nervous system (Figs. 114). Nerve ring located in ventral anterior proboscis region, occupying $~ 1 / 12$ of haemocoel volume, highly concentrated. Ganglia mostly fused, hard to distinguish from each other, somewhat asymmetrical. Pairs of pleural and cerebral ganglia fully fused with each other. Sub-esophageal not seen in detail. Esophageal aperture wide, central, located in middle region of pleural and cerebral ganglia, occupying about 1/6 of surface of nerve ring. Statocysts not visualyzed.

Shell measurements (length $x$ width in $\mathrm{mm}$ ): 今 $22 \mathrm{x} 12$; ㅇ $20.1 \mathrm{x} 12.8$; ㅇ $21.9 \mathrm{x}$ 11.6.

Distribution: Mauritius Islands to India, Japan and New Caledonia

Habitat: muddy bottoms, mangroves.

Material examined: MZSP: 55053; 1ठ, 2 , , Thailand: Chantaburi; Kung Kraben Bay, $12^{\circ} 35,16^{\prime} \mathrm{N} 101^{\circ}$ 54,4’E, (Coll. Luiz Simone, 22.viii.2005). 


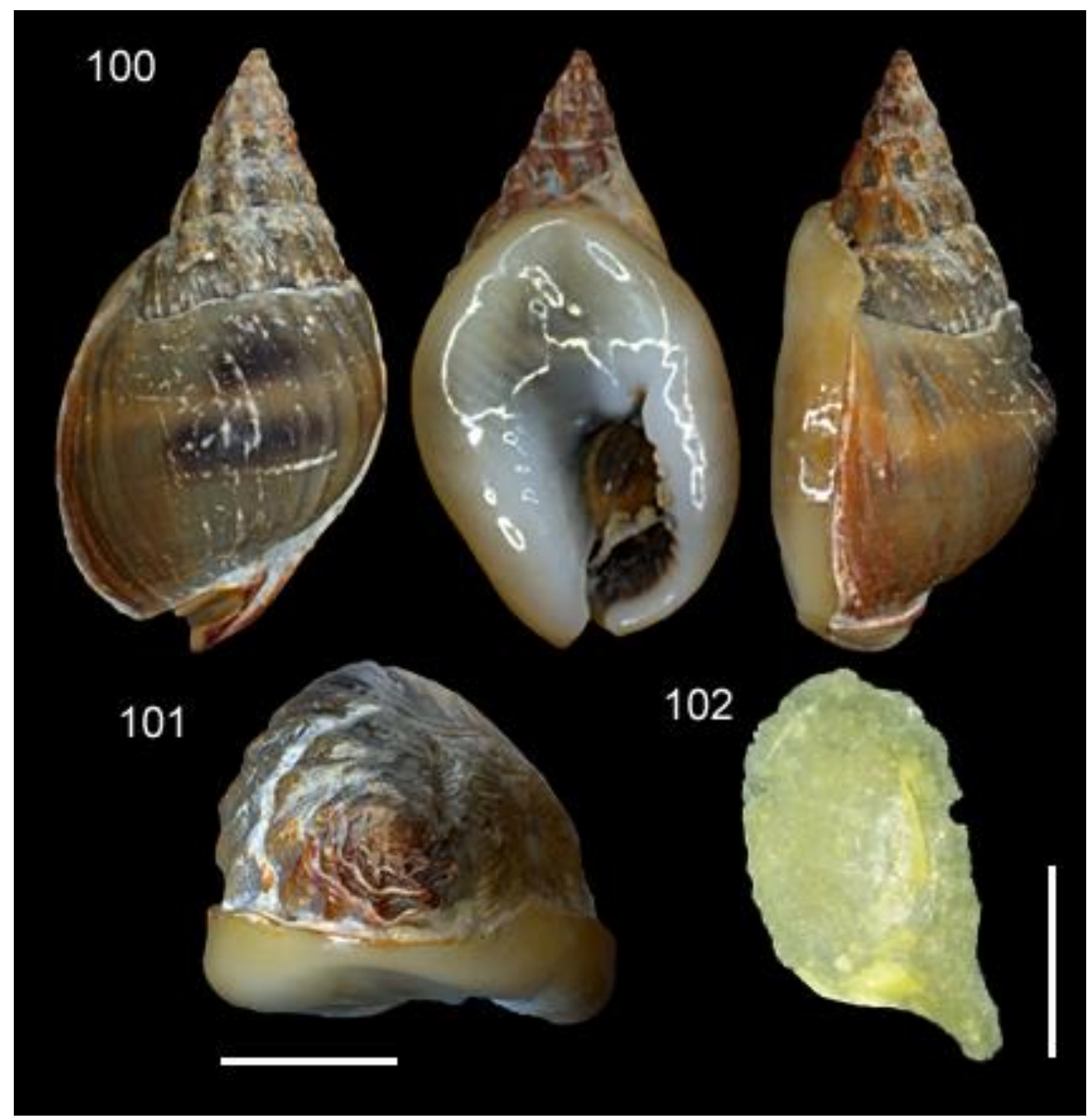

Figs. 100-102. Hinia pulla: MZSP 55053, shell and operculum; Fig. 100: Adult specimen, Shell, apertural, dorsal and lateral views (L 20.1); Fig. 101: same, apical view, scale = $5 \mathrm{~mm}$; Fig. 102: operculum dorsal view, scale $=3 \mathrm{~mm}$. 


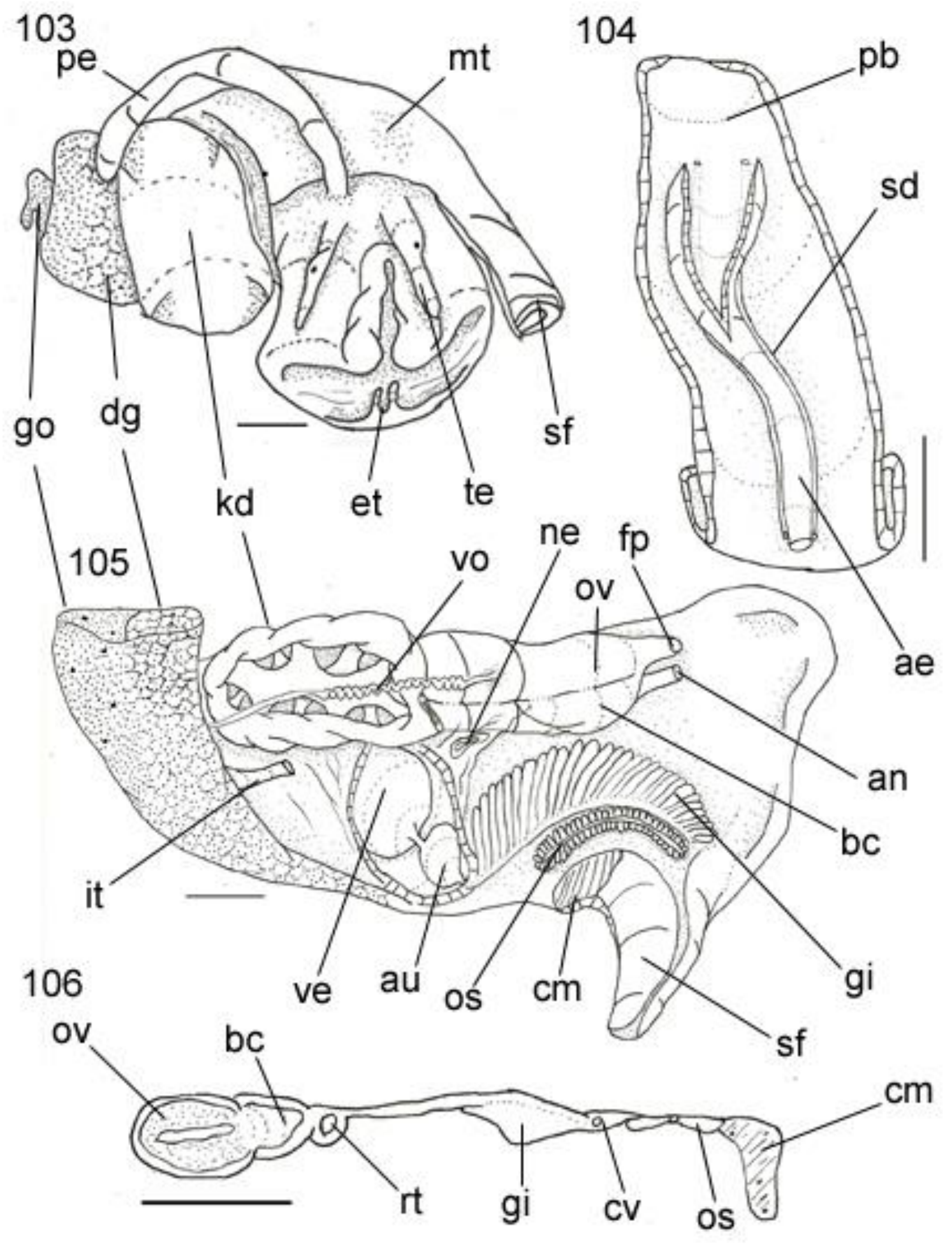

Figs. 103-106. Hinia pulla: Details of anatomy, Fig. 103: complete specimen extracted from shell (operculum removed), anterior-right view; Fig. 104: Proboscis and anterior esophagus opened longitudinally, showing salivary ducts and their apertures; Fig. 105: Pallial cavity roof, ventral view; Fig. 106: same, transverse section at middle level of osphradium. Scales $=2 \mathrm{~mm}$. 


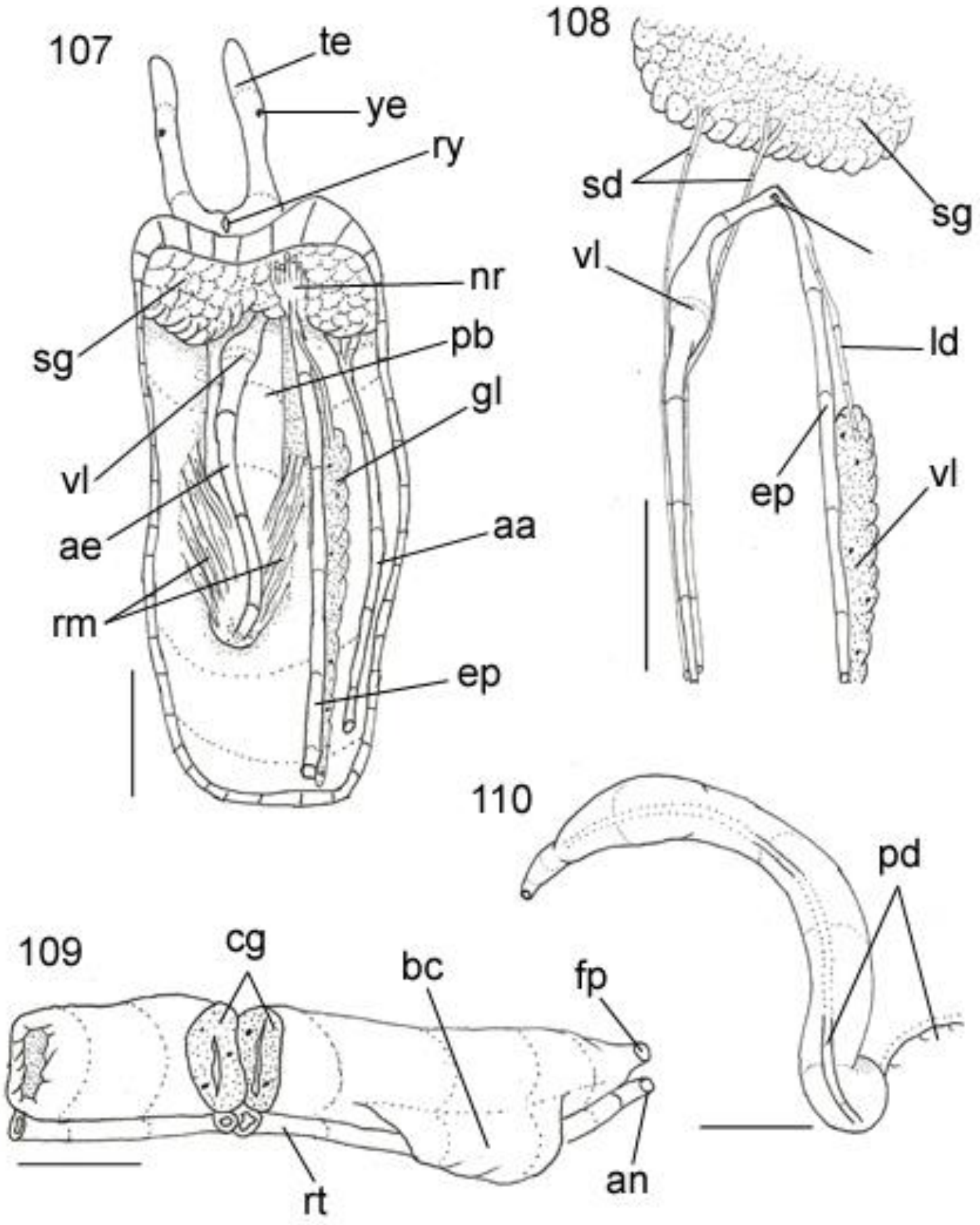

Figs. 107-110. Hinia pulla: Details of anatomy, Fig. 107 : Head and haemocoel, ventral view; Fig. 108: Mid and anterior region of posterior esophagus and associated structures, showing valve and gland of Leiblein; Fig. 109: Pallial oviduct, right lateral view; Fig. 110: Penis, lateral left view. Scales $=2 \mathrm{~mm}$. 

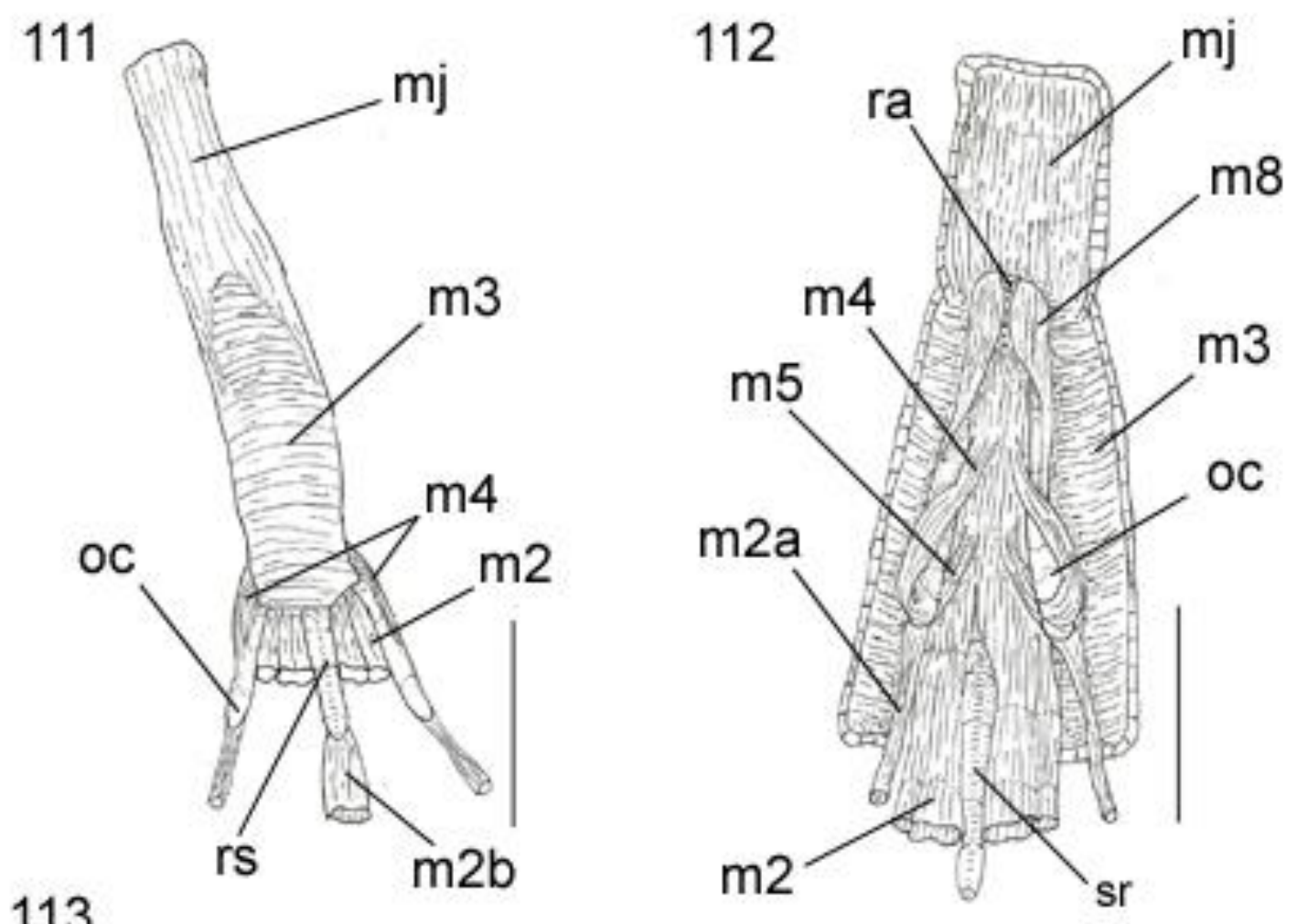

113
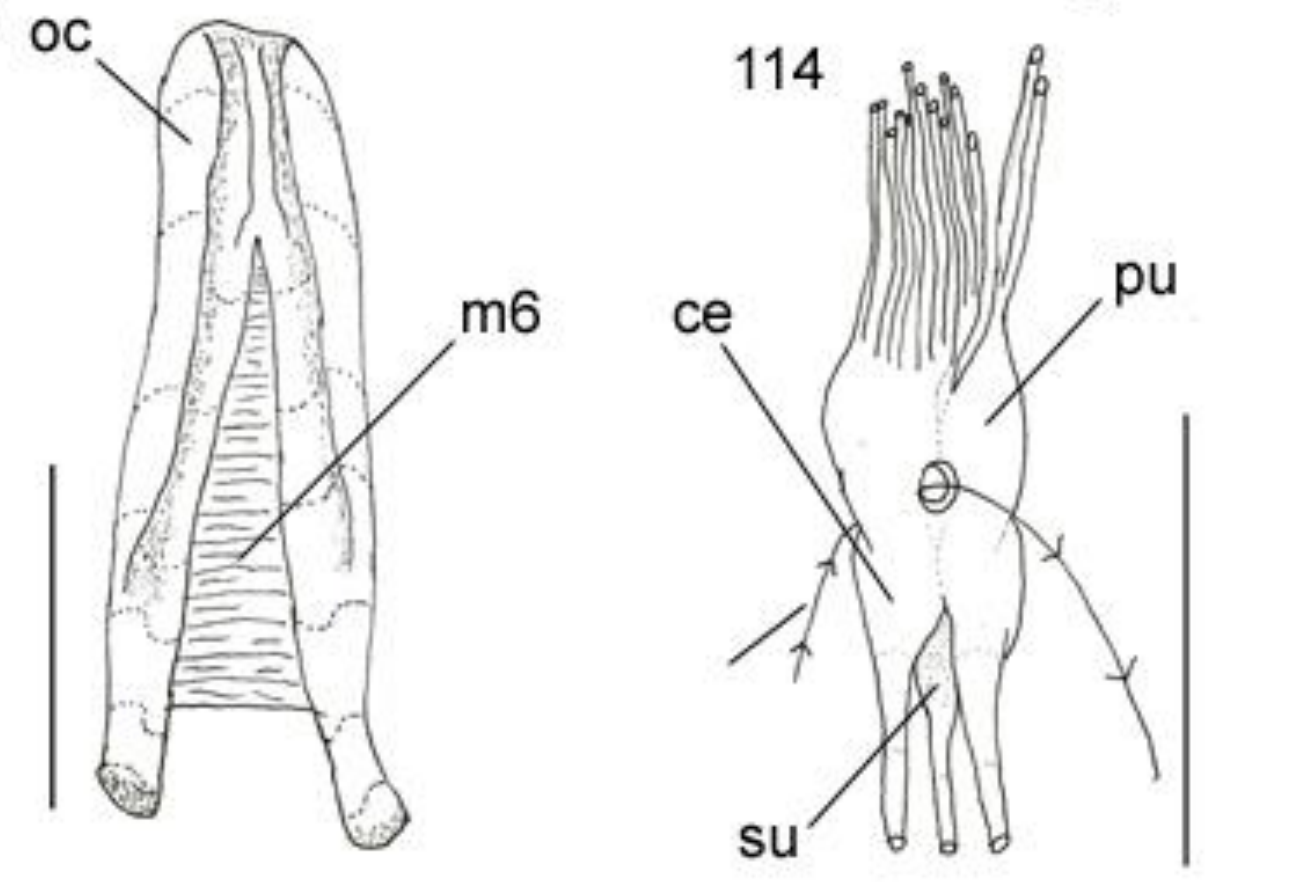

Figs. 111-114. Hinia pulla: Details of anatomy, Fig. 111: Odontophore, dorsal view, superficial layers showed; Fig. 112: Odontophore, dorsal view, superficial muscles dissected; Fig. 113: Odontophore cartilages, associated muscles shown; Fig. 114: Nerve ring. Ventral view. Scales $=2 \mathrm{~mm}$. 


\section{Hinia olivacea (Broderip \& Sowerby, 1829) comb. nov. \\ Figs. 115-128.}

Vide Cernorhorsky, 1984: Page: 132; plate: 23, figs 9-15.

Shell (Figs.115, 116). Ovate, about twice long as wide, with 5 convex whorls; color dark gray to brown for all over shell surface. Protoconch commonly eroded. Teleoconch sculpture composed of thick spiral lines along entire surface. Suture well marked, spire angle $\sim 63^{\circ}$, shoulder absent. Aperture prosocline, rounded, posteriorly acuminate, ca. 1/2 of shell length; color ocher; outer lip thick, palatal wall lirated; parietal rib weakly present; Parietal shield well developed, covering about $1 / 3$ of ventral surface of body whorl; Anal notch medially marked. Siphonal canal short, strong, deep, narrow ( 1/3 of aperture length) and dorsally recurved.

Head-foot (Figs. 119). Pallial cavity with $\sim 1$ whorl; muscular siphon located on left, length $\sim 1 / 3$ of head-foot length. Head protruded; tentacles closed from each other, elongated and narrow, 3x as long as head; eyes pedunculated, located in medium region of tentacles. Foot big, occupying almost entire body whorl (retracted), flat, bearing a pair of medium metapodial tentacles; pedal gland located in anterior edge of foot, forming a groove, extending to dorsum of foot (propodium). Opercular pad occupying $~ 1 / 8$ of dorsal area of foot, oval. Penis originated in right lateral region, posterior to cephalic base, at level of mantle edge. Columellar muscle small and broad, 1 whorl long. Haemocoel long and thin, extending dorsally along center of foot and columellar muscle, $2 \mathrm{x}$ as long as wide.

Operculum (Fig. 117). Medium size, ovate, horny, pale orange; occupying almost entire aperture. Nucleus terminal, inferior. Outer surface with normal concentric growth lines, forming undulations, located close to edge of foot.

Mantle organs (Figs. 121, 122). Osphradium short and wide, elliptical, length 1/5 of pallial cavity length, width $\sim 1 / 5$ of its width. Osphradial filaments short, broad. Ctenidial vein (efferent branchial vessel) uniformly narrow along its length. Gill long and wide, occupying $1 / 3$ of width of pallial cavity. Anterior end of gill rounded, ending gradually, inserted directly into pallial cavity. Gill filaments increasing in size in middle region. Posterior end of gill tapered, located in posterior region of mantle cavity, inserted into pericardium. Gill filaments low and rounded. Gonoducts not vizualized. Kidney occupying $~ 1 / 2$ of visceral mass volume, located on right side of anterior visceral end.

Circulatory and excretory systems (Fig. 121, 122). Same as previous species. Kidney occupying $1 / 2$ of pallial cavity length, renal lobe single, solid glandular; efferent 
renal vessel located at its right portion. Nephridial gland not seen in detail. Nephrostome small, longitudinal slit, located in anterior region of membrane between kidney and pallial cavity.

Digestive system (Figs. 120, 123, 125-127). Mouth longitudinal, narrow. Proboscis long and thin, occupying about $90 \%$ of haemocoel lenght. Rhynchodeal wall thin and membranous, involving $2 / 3$ of proboscis. Thin retractor muscles covering entire length of proboscis. Salivary glands same as previous species. Salivary ducts very narrow, running completely attached to anterior esophagus wall and, more anteriorly, inside dorsal wall of buccal cavity along the folds; opening very small, posteriorly on buccal mass. Valve of Leiblein absent. Gland of Leiblein absent. Accessory salivary glands absent. Anterior esophagus thin uniformly narrow along its length; walls muscular, with two strong internal longitudinal folds, occupying entire length of proboscis. Middle esophagus with the same diameter of anterior esophagus; posterior esophagus $\sim 90 \%$ of total haemocoel lenght, thin, with constant diameter along its entire length, differentiation between middle and posterior esophagus not clear. Stomach and digestive gland ducts not analyzed in detail.

Odontophore and buccal mass muscles: $m j$, like previous species; $m 1$, jugal muscles, several tinny and thin fibers which connected odontophore in proboscis wall; $m 2$, pair of strong protractor muscles of buccal mass, originating on inner surface of proboscis, running along entire odontophore, inserting in anterior region of odontophore cartilages; $m 2 a$, absent; $m 2 b$, absent; $m 3$, long and cylindrical muscle forming outer wall of odontophore, with transverse fibers; $m 4$, pairs of strong radular dorsal tensor muscles covering almost entire surface of posterior portion of odontophore cartilages, originating outside edges of cartilage and inserting into subradular membrane; $m 5$, pair of auxiliary dorsal tensor muscles of radula, originating inside edges of cartilage, adjacent to $\mathrm{m} 4$ insertion; $m 6$, horizontal muscle, thick, connecting ventral edges of cartilages, running $\sim 2 / 3$ of their length; $m 8$, pair of elliptical muscles, $\sim 1 / 4$ of total length of odontophore, originating at anterior end of odontophore cartilages, running along ventral surface of odontophore, inserting on anterior ventral surface of cartilages; $m 11$, pair of ventral tensor muscles of radula, about $1 / 3$ of total odontophore length, originating at ventral-posterior end of cartilages, crossing ventrally entire odontophore, inserting into ventral posterior surface of radula. Additional odontophore structures: $b r$, subradular membrane, thin, strong and translucent, along entire length of radular ribbon, covering inner surface of odontophore cartilages; $o c$, odontophore cartilages, about $3 \mathrm{x}$ long as wide, inner ventral 
surface concave, $\sim 1 / 5$ of anterior end fused with each other; $r s$, radular sac thin-walled, cylindrical, located at posterior end of radula; $n r$, radular nucleus width $\sim 1 / 2$ of radular sac width.

Radular teeth (Fig. 118). Rachidian tooth wide, comb-like, occupying about half of radular width; base curved, width $\sim 3 \times$ its length; $\sim 12$ triangular, sharp pointed cusps of similar size, except for some diminishment towards the side; lateral tooth hook-like, with two cusps of same size, base broad (equivalent to rachidian base width), obliquely disposed; radula ribbon equal between males and females.

Genital system. Male (Fig. 124). Vas deferens narrow, simple, straight, running along ventral surface of kidney up to pallial cavity. Prostate totally closed (tubular), running thought right mantle edge, at $\sim 1 / 3$ of total pallial cavity length. Vas deferens anterior to prostate, straight, running immersed into integument of dorsum, next to mantle border and penis base. Penis broad, length $\sim 2 / 4$ of total head-foot length, dorso-ventrally flattened and with wide point at the apex; presence of a keel, along entire left edge. Penial duct straight, running through center of penis, closed (tubular). Penial aperture distal, small, without papilla.

Female. Not analized.

Central nervous system (Fig. 128). Nerve ring located in ventral anterior proboscis region, occupying $~ 1 / 12$ of haemocoel volume, highly concentrated. Ganglia mostly fused, hard to distinguish from each other, somewhat asymmetrical. Pairs of pleural and cerebral ganglia fully fused with each other. Sub-esophageal ganglia located in middle region of cerebropleural ganglia. Esophageal aperture small, central, located in middle region of pedal and cerebral ganglia, occupying about 1/6 of surface of nerve ring. Statocysts located in ventral surface of pedal ganglia.

Shell measurements (length $x$ width in $\mathrm{mm}$ ): MZSP 71918; 2 ^ 28.8 x 16.2; 21.6 x 15.1 .

Distribution: S. E. Africa to India, China, Fiji.

Habitat: Mud bottoms, intertidal.

Material examined: MZSP 71918; 2ð, Fiji: Viti Levu, Man groove, low tide (J. Coltro, 09/ix/2006). 


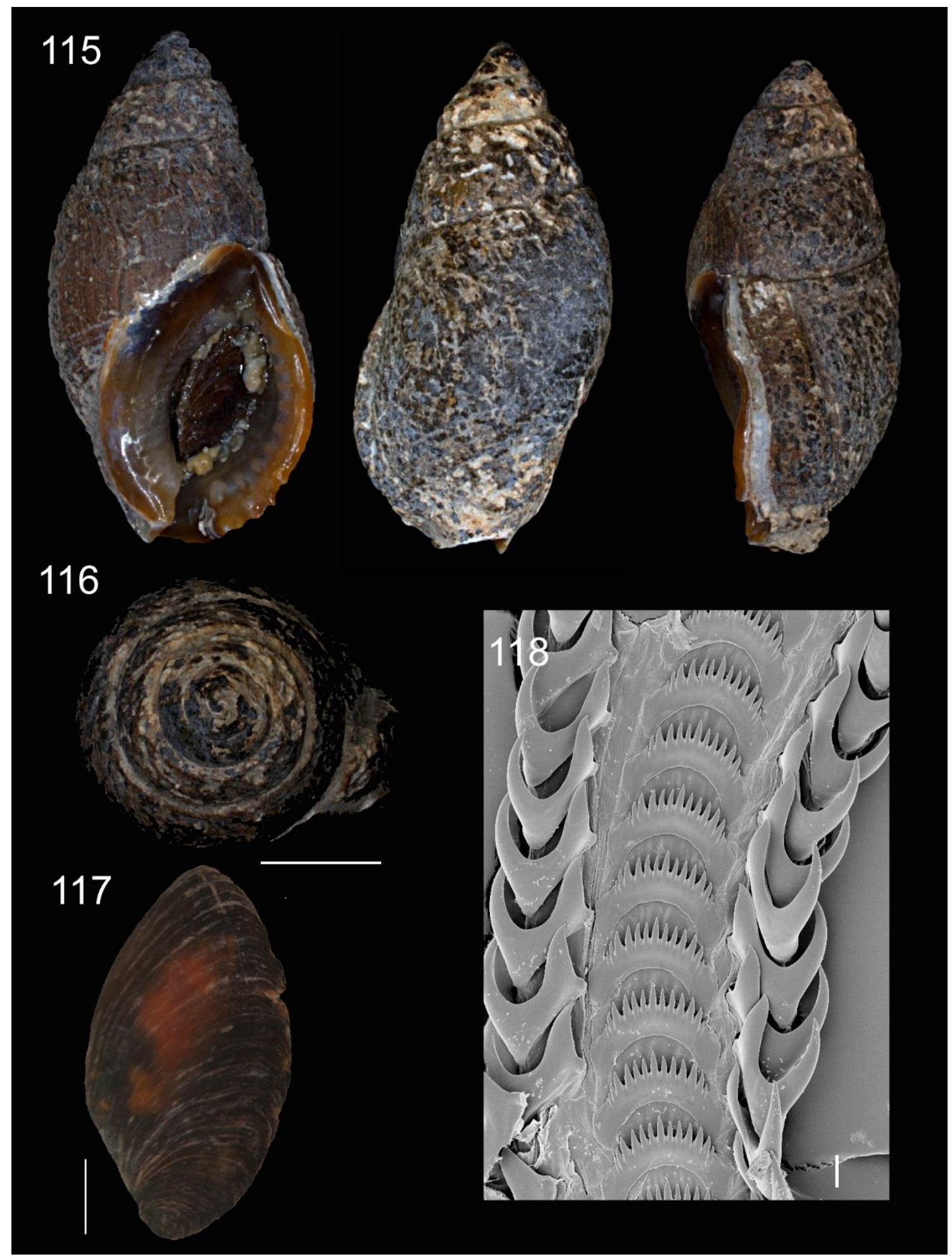

Figs. 115-118. Hinia olivacea: MZSP $71918 \hat{\jmath}$, shell, operculum and radula; Figs 115: Adult specimen, Shell apertural, dorsal and lateral view (L $28.8 \mathrm{~mm}$ ); Fig. 116: shell apical view, scale = 5mm; Fig. 117: Operculum dorsal view, scale $=2 \mathrm{~mm}$; Fig. 118; SEM of radula: Panoramic view of middle portion, scale $=30 \mu \mathrm{m}$. 


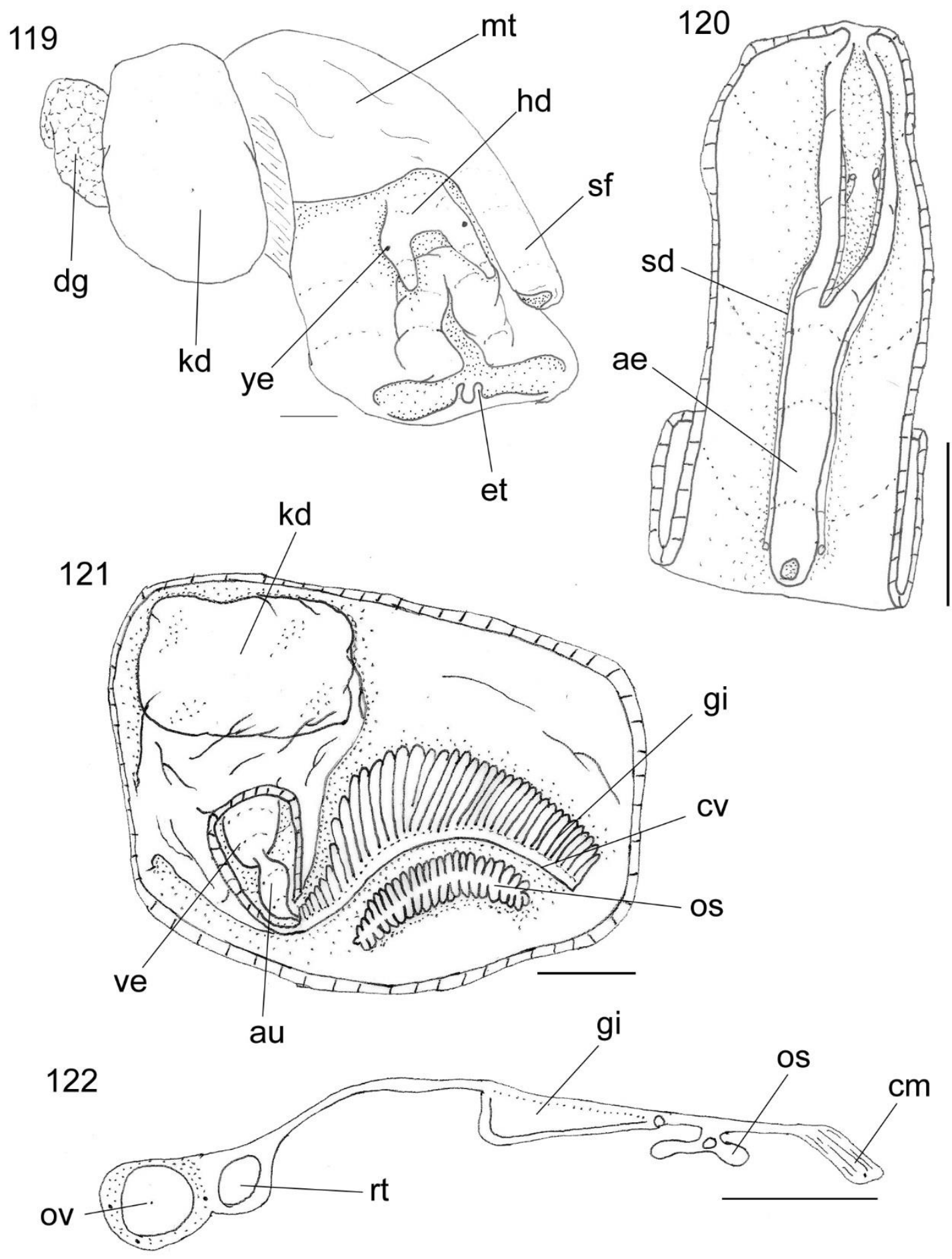

Figs. 119-122. Hinia olivacea: Details of anatomy, Fig. 119: complete specimen extracted from shell (operculum removed), anterior-right view; Fig. 120: Proboscis and anterior esophagus opened longitudinally, showing salivary ducts and their apertures; Fig. 121: Detail of Circulatory and excretory systems; Fig. 122: Pallial cavity roof, transverse section at middle level of osphradium. Scales $=2 \mathrm{~mm}$. 

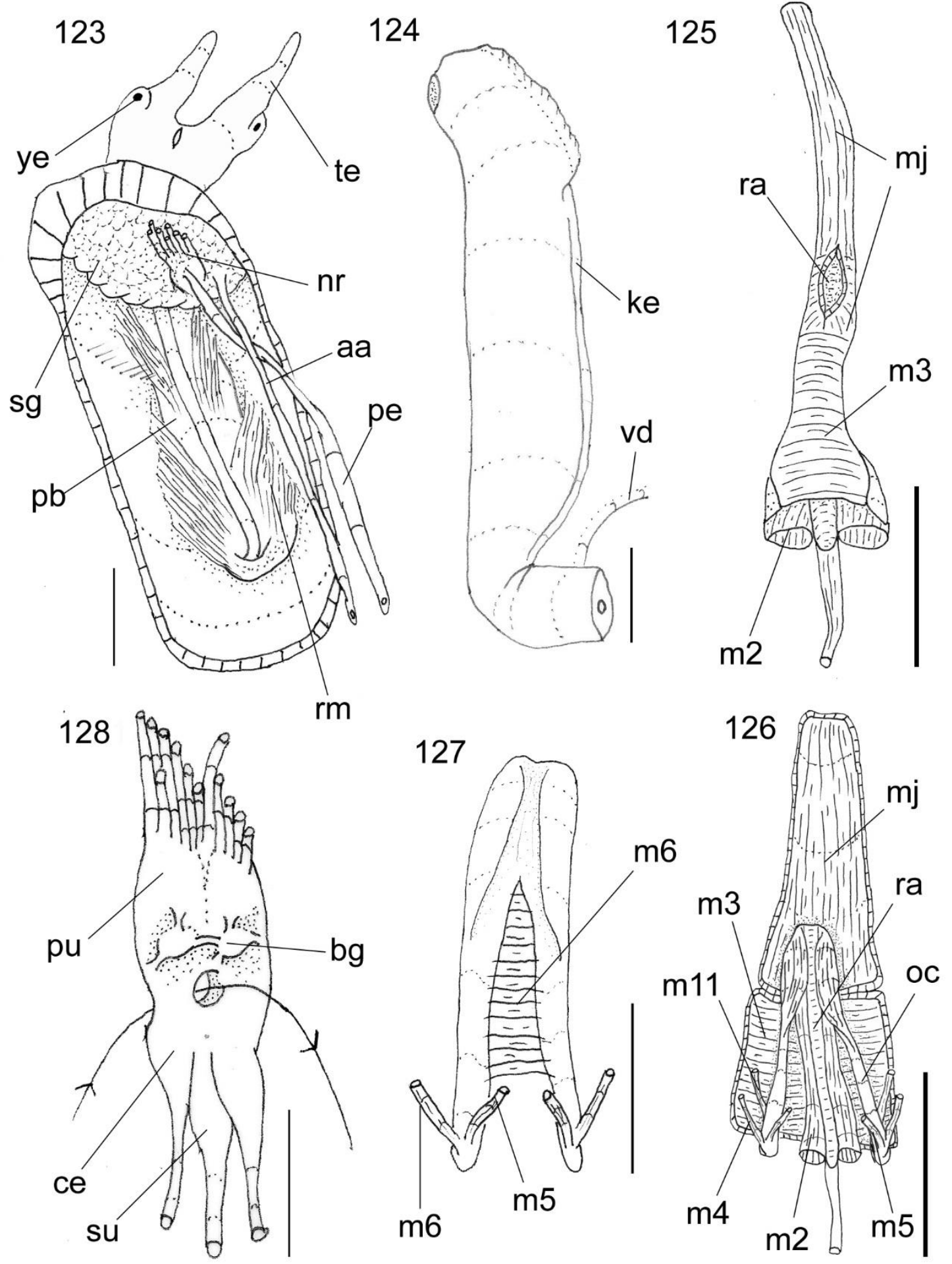

Figs. 123-128. Hinia olivacea: Details of anatomy, Fig. 123: Head and haemocoel, ventral view, foot and columellar muscle removed; Fig. 124: Penis, lateral left view; Fig. 125: Odontophore, dorsal view, superficial layers showed; Fig. 126: Odontophore, dorsal view, superficial muscles dissected; Fig. 127: Odontophore cartilages, associated muscles shown; Fig. 128: Nerve ring, dorsal view. ventral. Scales $=2$ $\mathrm{mm}$. 


\section{Hinia luteostoma (Bruguière, 1789) comb. nov. \\ Figs. 129-142.}

Nassarius luteostomus Broderip \& Sowerby, 1829.

Nassa luteostoma Broderip \& Sowerby, 1829: 376 orig. des.

Nassa xanthostoma Gray, 1839: 127 (pl. 36, fig. 3).

Nassa var. nodulifera Carpenter, 1857: 496.

Shell (Figs. 129, 130). Ovate, about twice long as wide, with 5-6 convex whorls; color dark gray. Protoconch commonly eroded. Teleoconch sculpture composed of light gray axial ribs along entire surface and dark gray spiral nodules near the sutures, spire angle $\sim 61^{\circ}$, shoulder absent. Aperture prosocline, rounded, posteriorly acuminate, ca. $1 / 3$ of shell length; color ocher; outer lip thick, palatal wall lirate, parietal rib weakly present; Parietal shield strongly developed, covering all most ventral surface of body whorl; Anal notch well marked. Siphonal canal short, strong, deep, narrow ( 1/2 of aperture length) and dorsally recurved.

Head-foot (Figs. 133, 134). Pallial cavity with $~ 1$ whorl; muscular siphon located on left, long, about same length of head-foot length. Head protruded; tentacles closed from each other, elongated and narrow, $3 \mathrm{x}$ as long as head; eyes pedunculated, located in medium region of tentacles. Foot big, occupying almost entire body whorl (retracted), flat, bearing a pair of medium metapodial tentacles; pedal gland located in anterior edge of foot, forming a groove, extending to dorsum of foot (propodium). Opercular pad occupying $~ 1 / 5$ of dorsal area of foot, oval. Penis originated in right lateral region, posterior to cephalic base, at level of mantle edge. Columellar muscle small and broad, 1 whorl long. Haemocoel long, extending dorsally along center of foot and columellar muscle, $2 \mathrm{x}$ as long as wide.

Operculum (Fig. 131). Medium size, ovate, horny, pale orange; occupying almost entire aperture. Nucleus terminal, inferior. Outer surface with normal concentric growth lines, forming undulations, located close to edge of foot.

Mantle organs (Figs. 135). Osphradium short and wide, elliptical, length 1/3 of pallial cavity length, width $\sim 1 / 5$ of its width. Osphradial filaments short, broad. Ctenidial vein (efferent branchial vessel) uniformly narrow along its length. Fold between gill and osphradium present. Gill long and wide, occupying 1/2 of width of pallial cavity. Anterior end of gill rounded, ending gradually, inserted directly into pallial cavity. Gill filaments increasing in size in middle region. Posterior end of gill tapered, located in posterior region of mantle cavity, inserted into pericardium. Gill filaments low and rounded. 
Gonoducts not vizualized. Kidney occupying 1/2 of visceral mass volume, located on right side of anterior visceral end.

Circulatory and excretory systems (Fig. 135). Same as previous species.

Digestive system (Figs. 135, 136, 137, 139-141). Mouth longitudinal, narrow. Proboscis long and thin, occupying about $80 \%$ of haemocoel length. Rhynchodeal wall thin and muscular, involving $2 / 3$ of proboscis. Thin retractor muscles covering half of proboscis length. Salivary glands same as previous species. Salivary ducts very narrow, running completely attached to anterior esophagus wall and, more anteriorly, inside dorsal wall of buccal cavity along the folds. Valve of Leiblein large, about 1/6 of odontophore volume, located in medium esophagus anterior to nervous ring, anterior region with transverse white band bearing long cilia, middle and posterior regions white, corresponding to inner gland occupying most of inner surface; bypass absent. Gland of Leiblein narrow and elongated, twice as long as middle esophagus, becoming gradually narrower posteriorly; duct of gland of Leiblein not seen in detail. Accessory salivary glands absent. Anterior esophagus thick, uniformly narrow along its length; walls muscular, occupying entire length of proboscis. Middle esophagus with the same diameter of anterior esophagus; posterior esophagus $~ 90 \%$ of total haemocoel lenght, thin, with constant diameter along its entire length, differentiation between middle and posterior esophagus not clear. Stomach and digestive gland ducts not visualized.

Odontophore and buccal mass muscles: $m j$, like previous species; $m 1$, jugal muscles, several tinny and thin fibers which connected odontophore in proboscis wall; $m 2$, pair of strong protractor muscles of buccal mass, originating on inner surface of proboscis, running along entire odontophore, inserting in anterior region of odontophore cartilages; $m 2 a$, absent; $m 2 b$, absent; $m 2 c$, absent; $m 3$, long and cylindrical muscle forming outer wall of odontophore, with transverse fibers; $m 4$, pairs of strong radular dorsal tensor muscles covering almost entire surface of posterior portion of odontophore cartilages, originating outside edges of cartilage and inserting into subradular membrane; $m 5$, pair of auxiliary dorsal tensor muscles of radula, originating inside edges of cartilage, adjacent to $\mathrm{m} 4$ insertion; $m 6$, horizontal muscle, thick, connecting ventral edges of cartilages, running $\sim 2 / 3$ of their length; $m 8$, pair of elliptical muscles, $\sim 1 / 4$ of total length of odontophore, originating at anterior end of odontophore cartilages, running along ventral surface of odontophore, inserting on anterior ventral surface of cartilages; $m 11$, pair of ventral tensor muscles of radula, about $1 / 3$ of total odontophore length, originating at ventral-posterior end of cartilages, crossing ventrally entire odontophore, inserting into 
ventral posterior surface of radula. Additional odontophore structures: $b r$, subradular membrane, thin, strong and translucent, along entire length of radular ribbon, covering inner surface of odontophore cartilages; $o c$, odontophore cartilages, about 3x long as wide, inner ventral surface concave, $\sim 1 / 3$ of anterior end fused with each other; $r s$, radular sac thin-walled, cylindrical, located at posterior end of radula; $n r$, radular nucleus width $\sim 1 / 2$ of radular sac width.

Radular teeth (Fig. 132). Rachidian tooth wide, comb-like, occupying about half of radular width; base curved, width $\sim 3 \times$ its length; $~ 14$ triangular, sharp pointed cusps of similar size, except for some diminishment towards the side; lateral tooth hook-like, with two cusps of same size, base broad (equivalent to rachidian base width), obliquely disposed; radula ribbon equal between males and females.

Genital system. Male (Fig. 138). Vas deferens narrow, simple, straight, running along ventral surface of kidney up to pallial cavity. Prostate totally closed (tubular), running thought right mantle edge, at $\sim 1 / 3$ of total pallial cavity length. Vas deferens anterior to prostate, straight, running immersed into integument of dorsum, next to mantle border and penis base. Penis slender, length $\sim 2 / 3$ of total head-foot length, cylindrical. Penial duct straight, running through center of penis, closed (tubular). Penial aperture distal, small, without papilla.

Female (Figs. 135, 136). Visceral oviduct narrow, straight, running along dorsal surface of kidney in first whorl of visceral mass, located in front of pallial cavity. Posterior region of pallial oviduct protruding into kidney, occupying $~ 2 / 3$ of length of pallial cavity and 1/5 of its width. Albumen gland posterior, whitish, thin-walled, occupying $\sim 1 / 3$ of pallial oviduct. Capsule gland $\sim 2 / 3$ of oviduct, elongated, orange, thick-walled, female genital pore simple, small, located at dorsal surface of bursa copulatrix. Bursa copulatrix rounded, muscular, occupying about $1 / 5$ of oviduct length. Cement gland absent.

Central nervous system (Fig. 142). Nerve ring located in ventral anterior proboscis region, occupying $~ 1 / 12$ of haemocoel volume, highly concentrated. Ganglia mostly fused, hard to distinguish from each other, somewhat asymmetrical. Pairs of pleural and cerebral ganglia fully fused with each other. Sub-esophageal ganglia located in middle region of cerebropleural ganglia. Esophageal aperture small, central, located in middle region of pedal and cerebral ganglia, occupying about 1/6 of surface of nerve ring. Statocysts located in ventral surface of pedal ganglia. 
Shell measurements (length $x$ width in $\mathrm{mm}$ ): MZSP 68373; $3 ð 17.9 \times 11.9 ; 18.3$ x 12.7; 17.5 x $11.6 ; 2$ q 18.6 x 13.1; 15.4 x 10.2.

Distribution: Panamá.

Habitat: fine and sand bottoms, intertidal.

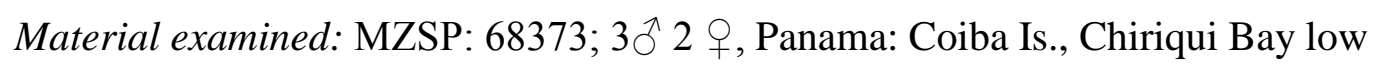
tide (Coll. Local people, i/2006). 


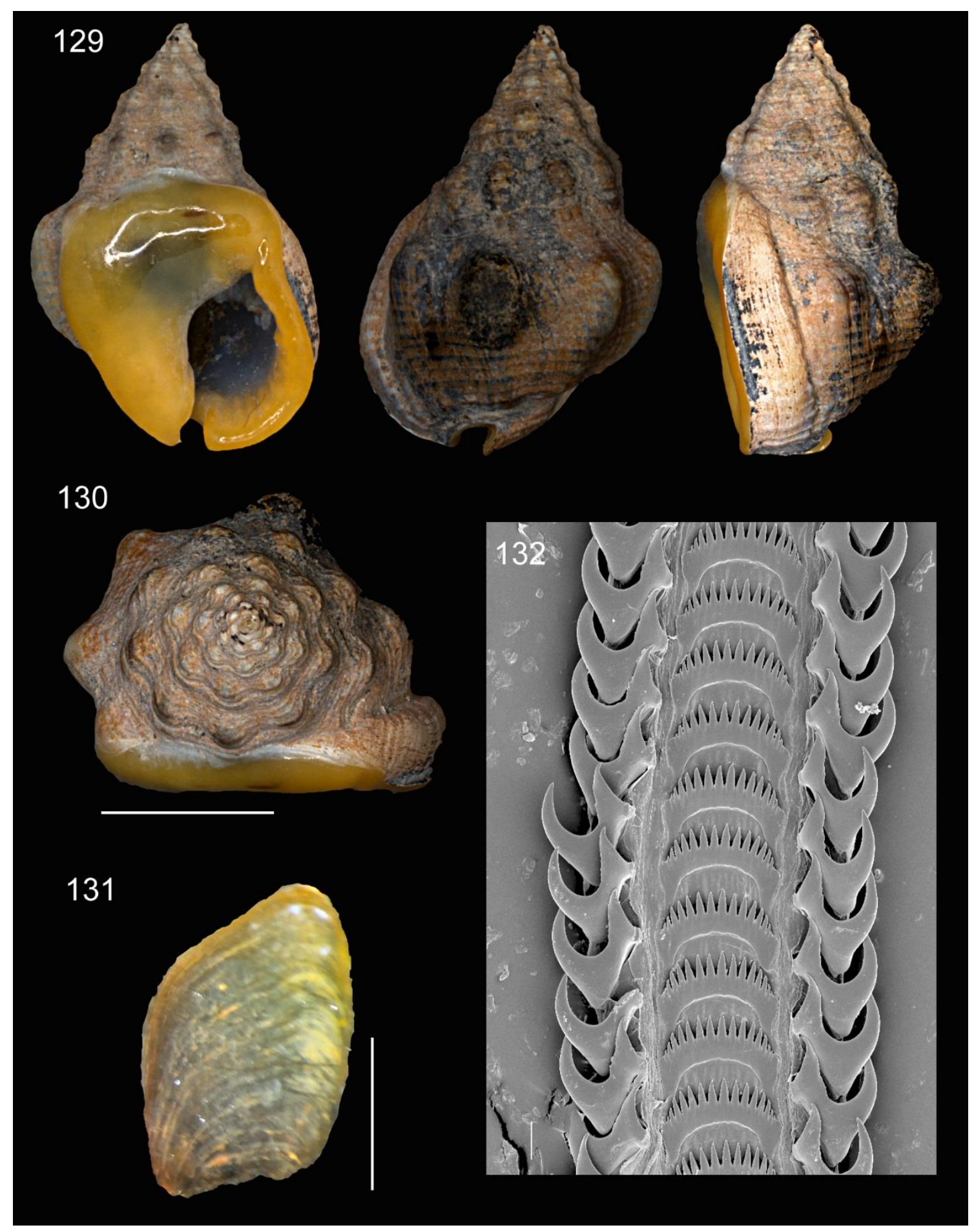

Figs. 129-132. Hinia luteostoma: MZSP 68373 $q$, shell, operculum and radula; Fig. 129: Adult specimen, Shell apertural, dorsal and lateral view (L $18.6 \mathrm{~mm}$ ); Fig. 130: shell apical view, scale: 5mm; Fig. 131: Operculum dorsal view, scale $=2 \mathrm{~mm}$; Fig. 132; SEM of radula: Panoramic view of middle portion, scale $=30 \mu \mathrm{m}$. 


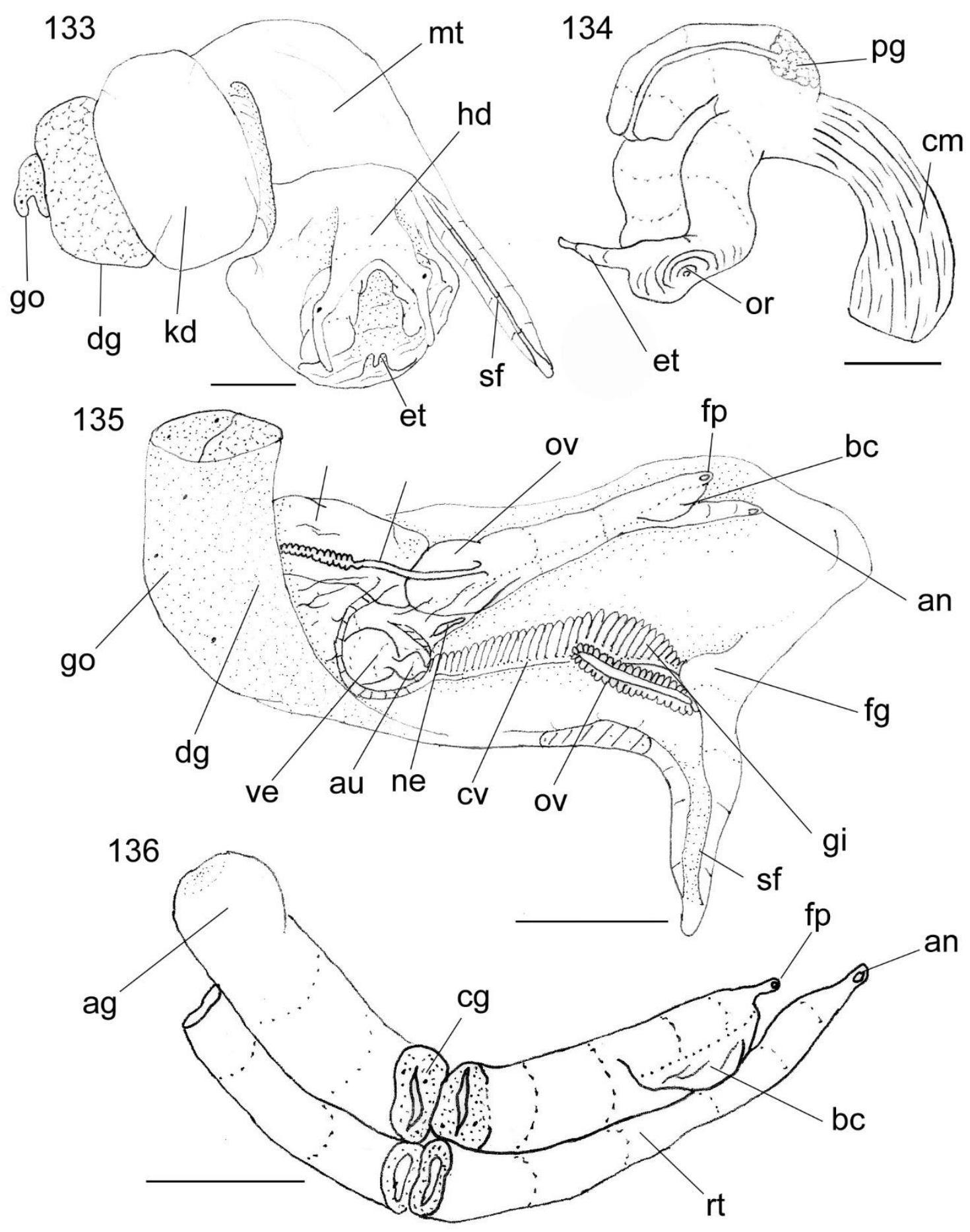

Figs. 133-136. Hinia luteostoma: Details of anatomy, Fig. 133: complete specimen extracted from shell (operculum removed), anterior-right view; Fig. 134: Foot of female, sagittal section; Fig. 135: Pallial cavity roof, ventral view; Fig. 136: Pallial oviduct, right lateral view. Scales $=2 \mathrm{~mm}$. 


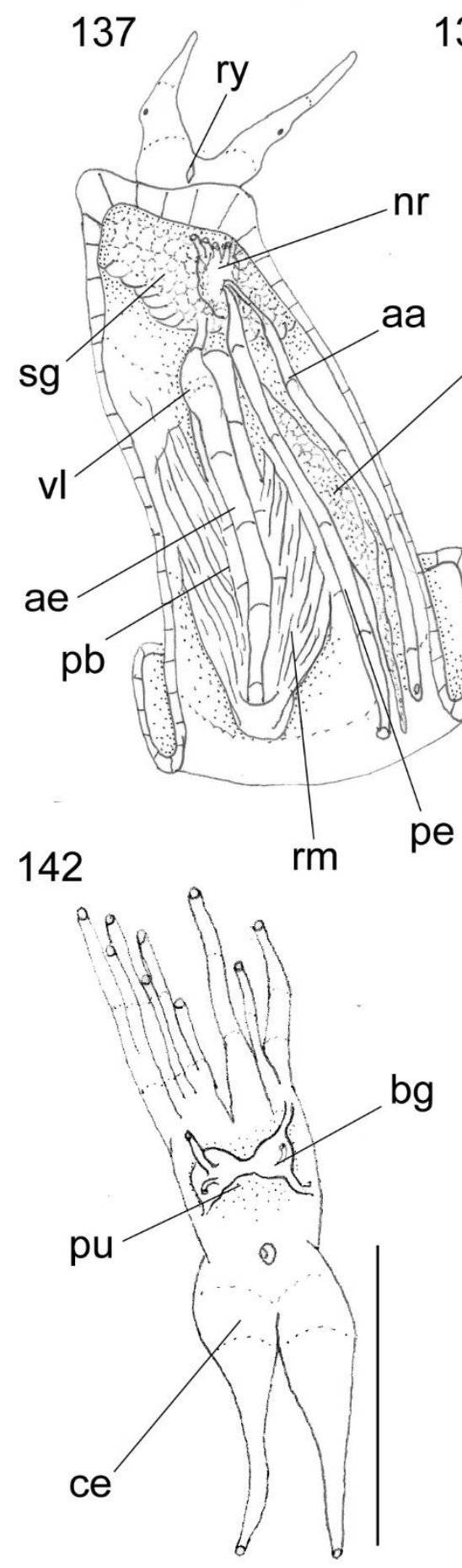

139
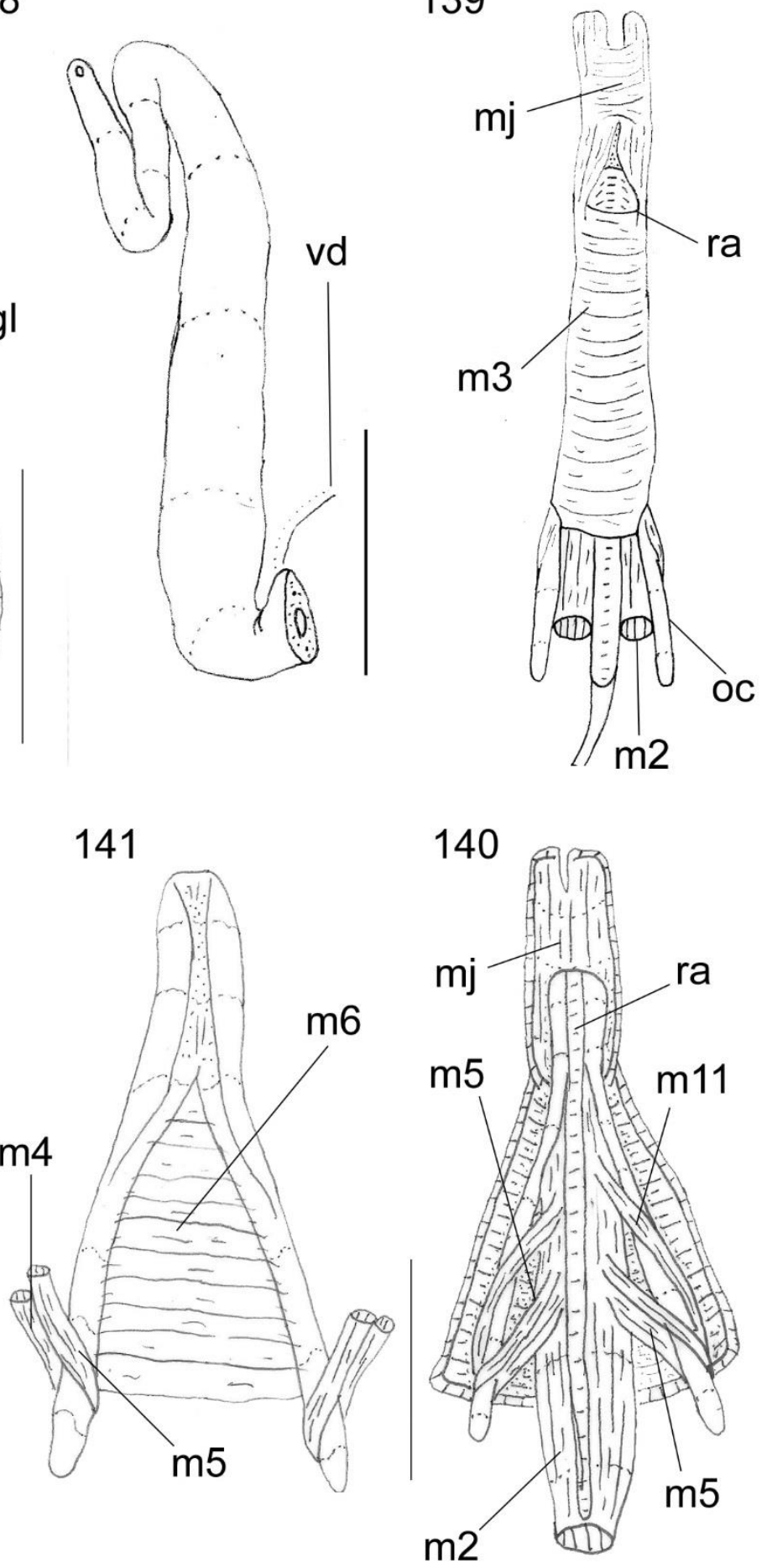

Figs. 137-142. Hinia luteostoma: Details of anatomy, Fig. 137: Head and haemocoel, ventral view, foot and columellar muscle removed; Fig. 138: Penis, lateral left view; Fig. 139: Odontophore, dorsal view, superficial layers showed; Fig. 140: Odontophore, dorsal view, superficial muscles dissected; Fig. 141: Odontophore cartilages, associated muscles shown; Fig. 142: Nerve ring, dorsal view. ventral. Scales $=2$ $\mathrm{mm}$. 


\section{Tribe Cyclopini tribe nov.}

\section{Genus Cyclope Risso, 1826}

Type species: Cyclope neritoidea (Keen, 1964) by S.D.

\section{Cyclope sp.}

\section{Figs. 143-157.}

Shell (Figs. 143, 144). Ovate, "neritoidea form", spiral low; color brown, with cream and white lines along surface of whorls. Protoconch small, smooth, amber, with $\sim 1$ 1/12 whorls; transition to teleoconch hardly indicated by a depression and by the difference of sculpturing. Teleoconch sculpture composed of white axial lines along entire surface, shoulder absent. Aperture big, prosocline, rounded, posteriorly acuminate, ca. 1/2 of body whorl; color amber; outer lip thick, palatal wall smooth, glossy; parietal rib absent; Parietal shield strongly developed, covering about $1 / 2$ of ventral surface of body whorl; Anal notch weekly marked. Siphonal canal short, strong, deep, narrow ( 1/4 of aperture length) and dorsally recurved.

Head-foot (Figs. 147, 148). Pallial cavity covering $1 / 2$ of total animal length; muscular siphon located on left, length $\sim 1 / 2$ of head-foot length. Head not protruded; tentacles base closed from each other, elongated and narrow; eyes pedunculated, located in medium region of tentacles. Foot big, occupying entire body whorl (retracted), flat, bearing a pair of medium metapodial tentacles; pedal gland located in anterior medium region of foot, forming a groove, extending to dorsum of foot (propodium). Opercular pad occupying $\sim 1 / 8$ of dorsal area of foot, oval. Penis originated in right lateral region, posterior to cephalic base, at level of mantle edge. Columellar muscle small and broad, $1 / 2$ whorl long.

Operculum (Fig. 145). Medium size, ovate, horny, pale yellow; occupying half aperture. Nucleus terminal, inferior. Outer surface with normal concentric growth lines, forming undulations. Scar elliptical, occupying about $2 / 3$ of inner surface, located close to edge of foot; expansions in the form of spines on right sides.

Mantle organs (Figs. 150, 151). Mantle cavity covering $~ 1$ whorl. Siphon long, width $1 / 4$ of mantle cavity width, length $1 / 2$ of mantle cavity length. Right base of siphon high, width about three times as mantle edge width; left base low ending gradually. Osphradium long and wide, elliptical, length $2 / 3$ of pallial cavity length, width $\sim 1 / 5$ of its width. Osphradial filaments short, broad. Ctenidial vein (efferent branchial vessel) uniformly narrow along its length. Gill small, occupying 1/4 of length and 1/6 of width of pallial cavity. Anterior end of gill rounded, ending gradually, inserted directly into 
pallial cavity. Gill filaments increasing in size in middle region. Posterior end of gill tapered, located in posterior region of mantle cavity, inserted into pericardium. Gill filaments low high pointed. Right side of pallial cavity almost entirely filled by gonoducts. Rectum long and thick, occupying $~ 2 / 3$ of pallial cavity width. Anus simple, distance between anus and mantle border 1/5 of total pallial cavity length. Anal gland absent.

Visceral mass (Figs. 151). About 1 whorls posterior to mantle cavity. Digestive gland dark beige, occupying $~ 80 \%$ of visceral mass, encircling stomach. Gonad orange with small black spots, located on columellar surface, posterior to stomach. Seminal vesicle of males located in anterior portion of gonad, $\sim 1 / 2$ of its size. Kidney small, occupying $\sim 1 / 4$ of visceral mass volume, located on right side of anterior visceral end.

Circulatory and excretory systems (Fig. 150, 151). Reno-pericardial region occupying 1 whorl, adjacent to mantle cavity; triangular shaped. Pericardium occupying 1/4 of reno-pericardial region, posterior to gill; situated on left anterior margin of visceral mass. Auricle triangular membranous, anterior to ventricle; with three connections: on upper right side with kidney, on anterior right side with gill, and on posterior left side with ventricle. Ventricle $2 \mathrm{x}$ as large as auricle. Kidney occupying 1/4 of pallial cavity length, renal lobe single, solid; efferent renal vessel located at its right portion. Nephridial gland not seen in detail. Nephrostome small, transversal slit, located in anterior region of membrane between kidney and pallial cavity.

Digestive system (Figs. 148, 152, 155-157). Mouth longitudinal, narrow. Proboscis long and broad, occupying about $90 \%$ of haemocoel lenght. Rhynchodeal wall thick and membranous, involving $2 / 3$ of proboscis. Thick retractor muscles covering posterior end of proboscis. Salivary glands located at anterior portion of haemocoel, occupying $\sim 1 / 5$ of haemocoel volume, entirely involving nerve ring, middle esophagus and anterior portion of proboscis. Salivary ducts very narrow, running completely attached to anterior esophagus wall and, more anteriorly, inside dorsal wall of buccal cavity along the folds; opening very small, closed to the mouth. Valve of Leiblein medium, about 1/8 of proboscis volume, located in medium esophagus anterior to nervous ring, diameter about 1/5x of the medium esophagus, anterior region with transverse white band bearing long cilia, middle and posterior regions white, corresponding to inner gland that occupies most of inner surface. Gland of Leiblein narrow and elongated, sinuous, equally narrower towards all length, duct of Gland of Leiblein, short and narrow. Accessory salivary glands absent. Anterior esophagus thin uniformly narrow along its length; walls 
muscular, with two strong internal longitudinal folds, occupying entire length of proboscis. Middle esophagus with the same diameter of anterior esophagus; posterior esophagus $\sim 90 \%$ of total haemocoel length, thin, with constant diameter along its entire length, differentiation between middle and posterior esophagus not clear. Stomach and digestive gland ducts not analyzed in detail.

Odontophore and buccal mass muscles: $m j$, thick of perioral muscles connected on both sides, dorsal and ventral, surrounding odontophore cartilages long, about 1/8 of odontophore length,; $m 1$, jugal muscles, several tinny and thin fibers which connected odontophore in proboscis wall; $m 2$, Strong protractor muscles of buccal mass, originating on inner surface of proboscis, running along entire odontophore, inserting in anterior region of odontophore cartilages; $m 2 a$, pair of retractor muscles of buccal mass, originating on dorsal surface of haemocoel, inserting at end of posterior margin of odontophore cartilages; $m 2 b$, absent; $m 2 c$, absent; $m 3$, long and cylindrical muscle forming outer wall of odontophore, with transverse fibers; $m 4$, pairs of strong radular dorsal tensor muscles covering almost entire surface of posterior portion of odontophore cartilages, originating outside edges of cartilage and inserting into subradular membrane; $m 5$, pair of auxiliary dorsal tensor muscles of radula, originating inside edges of cartilage, adjacent to $\mathrm{m} 4$ insertion; $m 6$, horizontal muscle, thick, connecting ventral edges of cartilages, running $\sim 1 / 2$ of their length; $m 8$, pair of elliptical muscles, $\sim 1 / 45 \mathrm{f}$ total length of odontophore, originating at anterior end of odontophore cartilages, running along ventral surface of odontophore, inserting on anterior ventral surface of cartilages; $m 11$, pair of ventral tensor muscles of radula, about $1 / 3$ of total odontophore length, originating at ventral-posterior end of cartilages, crossing ventrally entire odontophore, inserting into ventral posterior surface of radula. Additional odontophore structures: $b r$, subradular membrane, thin, strong and translucent, along entire length of radular ribbon, covering inner surface of odontophore cartilages; $o c$, odontophore cartilages, about 3x long as wide, inner ventral surface concave, $\sim 1 / 4$ of anterior end fused with each other; $r s$, radular sac thin-walled, cylindrical, located at posterior end of radula; $n r$, radular nucleus width $\sim 1 / 2$ of radular sac width.

Radular teeth (Fig. 146). Rachidian tooth wide, comb-like, occupying about half of radular width; base curved, width $\sim 3 \times$ its length; $\sim 14$ triangular, sharp pointed cusps of similar size, except for some diminishment towards the side; lateral tooth hook-like, with two principal cusps, base broad (equivalent to rachidian base width), obliquely disposed; main lateral cusp widely curved inwards, about as long as base; secondary cusp 
approximately $1 / 2$ size of main lateral cusp, divided in three smallest cusps; radula ribbon equal between males and females; jaws absent.

Genital system. Male (Fig. 153). Vas deferens narrow, simple, straight, running along ventral surface of kidney up to pallial cavity. Prostate totally closed (tubular), running thought right mantle edge, at $\sim 1 / 3$ of total pallial cavity length. Vas deferens anterior to prostate, straight, running immersed into integument of dorsum, next to mantle border and penis base. Penis short, broad, length $\sim 1 / 4$ of total head-foot length, dorsoventrally flattened and with wide point at base; base curved, apical region tapered. Penial duct straight, running through center of penis, closed (tubular). Penial aperture distal, small.

Female (Figs. 151). Visceral oviduct narrow, straight, running along dorsal surface of kidney in first whorl of visceral mass, located in front of pallial cavity. Posterior region of pallial oviduct protruding into kidney, occupying $\sim 1 / 2$ of length of pallial cavity and $1 / 3$ of its width. Albumen gland small, posterior, whitish, thin-walled, occupying $\sim 1 / 5$ of pallial oviduct. Capsule gland $\sim 2 / 3$ of oviduct, elongated, orange, thick-walled. Vaginal atrium thin, tubular, occupying $~ 1 / 8$ of oviduct; walls thick, muscular, female genital pore narrow. Bursa copulatrix absent. Cement gland absent.

Central nervous system (Fig. 157). Nerve ring located in ventral anterior proboscis region, occupying $~ 1 / 12$ of haemocoel volume, highly concentrated. Ganglia mostly fused, hard to distinguish from each other, somewhat asymmetrical. Pairs of pleural and cerebral ganglia fully fused with each other. Sub-esophageal not seen in detail. Esophageal aperture wide, central, located in midlle region of pleural and cerebral ganglia, occupying about $1 / 6$ of surface of nerve ring. Statocysts not visualyzed.

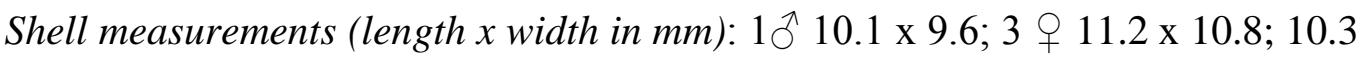
x $9.9 ; 11.6 \times 10.1$.

Distribution: Ismalia, Egypt.

Habitat: Fine sand bottoms.

Material examined: AUSM C478558.001; Egypt, Suez Canal, Ismalia (D. Dexter col. 05/iv/1985). 


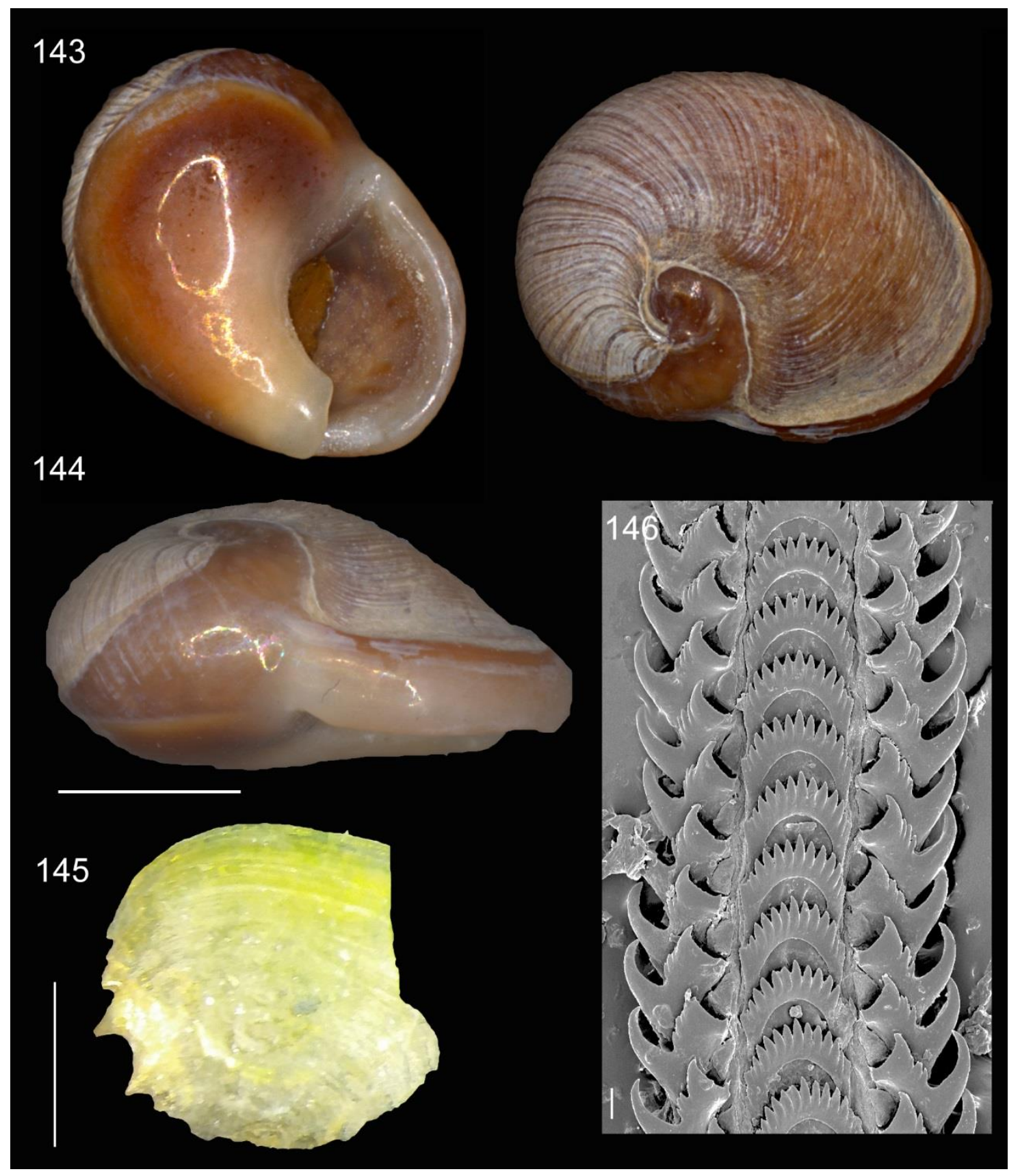

Figs. 143-146. Cyclope sp.: AUSM C478558.001 $q$, shell, operculum and radula; Fig. 143: Adult specimen, Shell apertural, and dorsal view (L $11.2 \mathrm{~mm}$ ); Fig. 144: shell lateral view, scale = $5 \mathrm{~mm}$; Fig. 145: Operculum dorsal view, scale $=2 \mathrm{~mm}$; Fig. 146; SEM of radula: Panoramic view of middle portion, scale $=30 \mu \mathrm{m}$. 


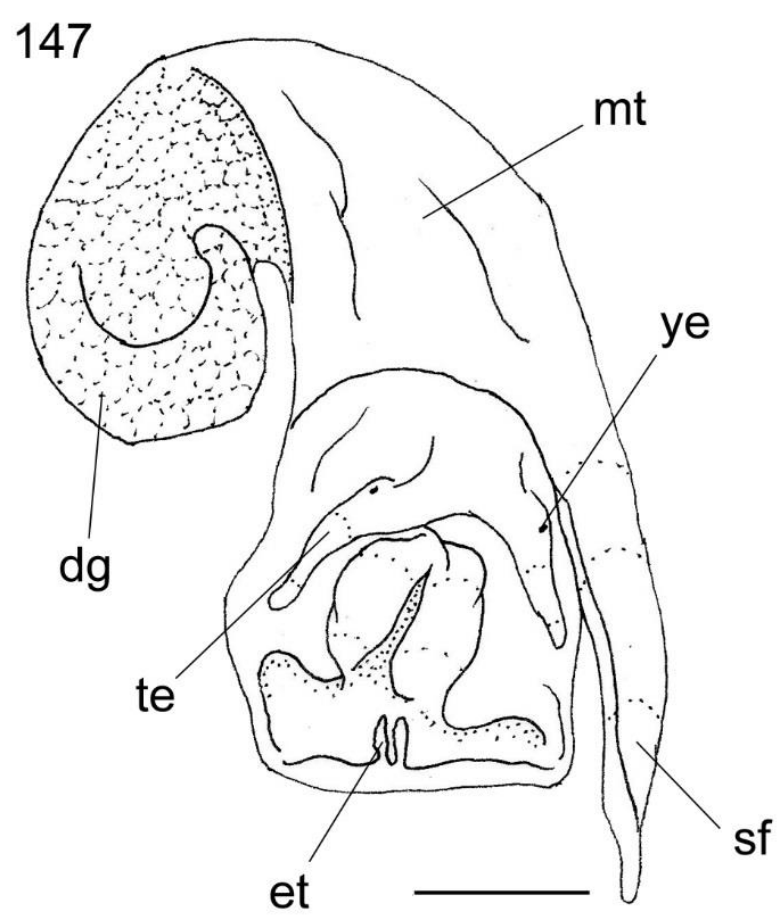

148
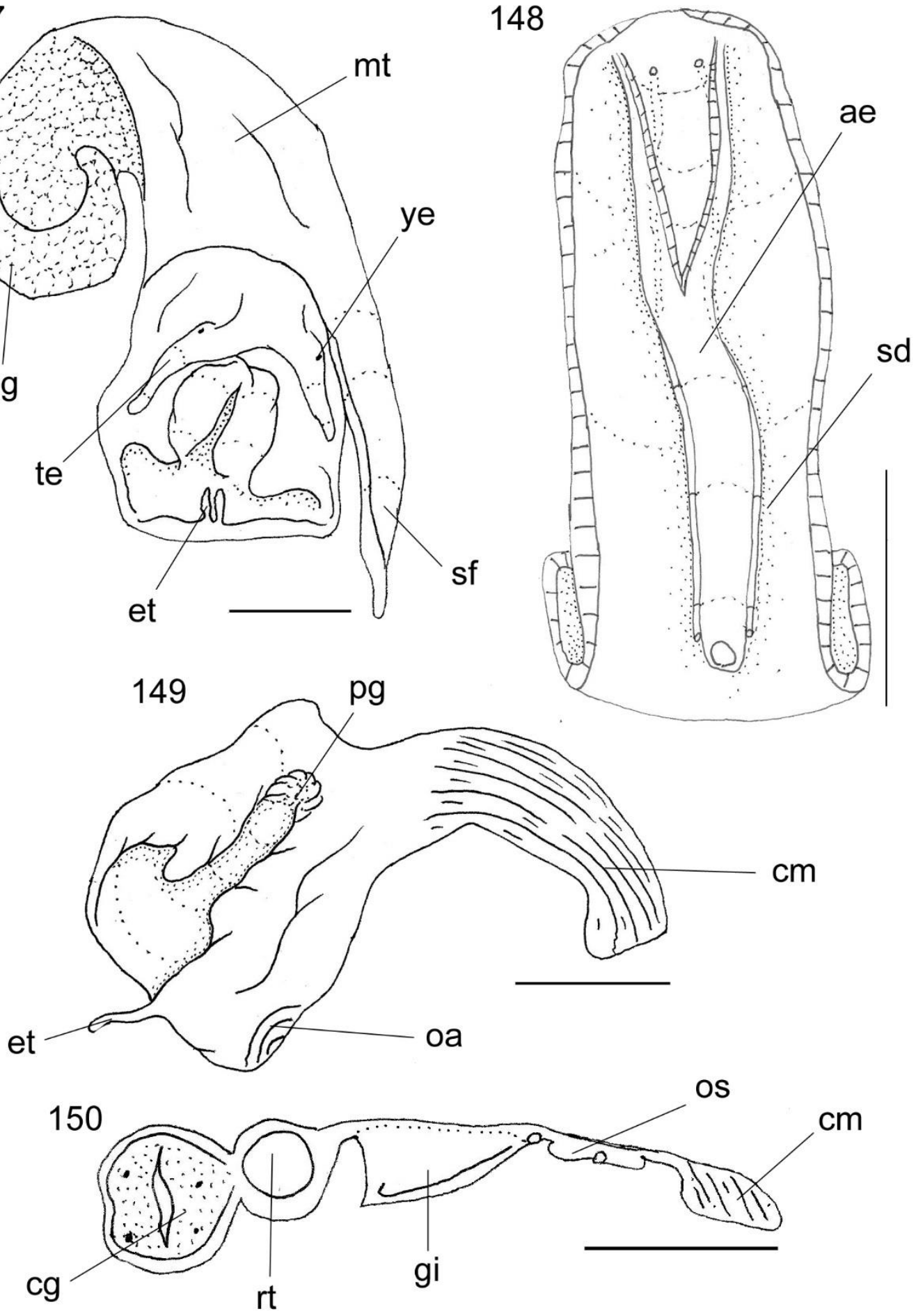

Figs. 147-150. Cyclope sp. Details of anatomy, Fig. 147: complete specimen extracted from shell (operculum removed), anterior-right view; Fig. 148: Proboscis and anterior esophagus opened longitudinally, showing salivary ducts and their apertures; Fig. 149: Foot of female, sagittal section; Fig. 150: Pallial cavity roof, transverse section at middle level of osphradium. Scales $=2 \mathrm{~mm}$. 


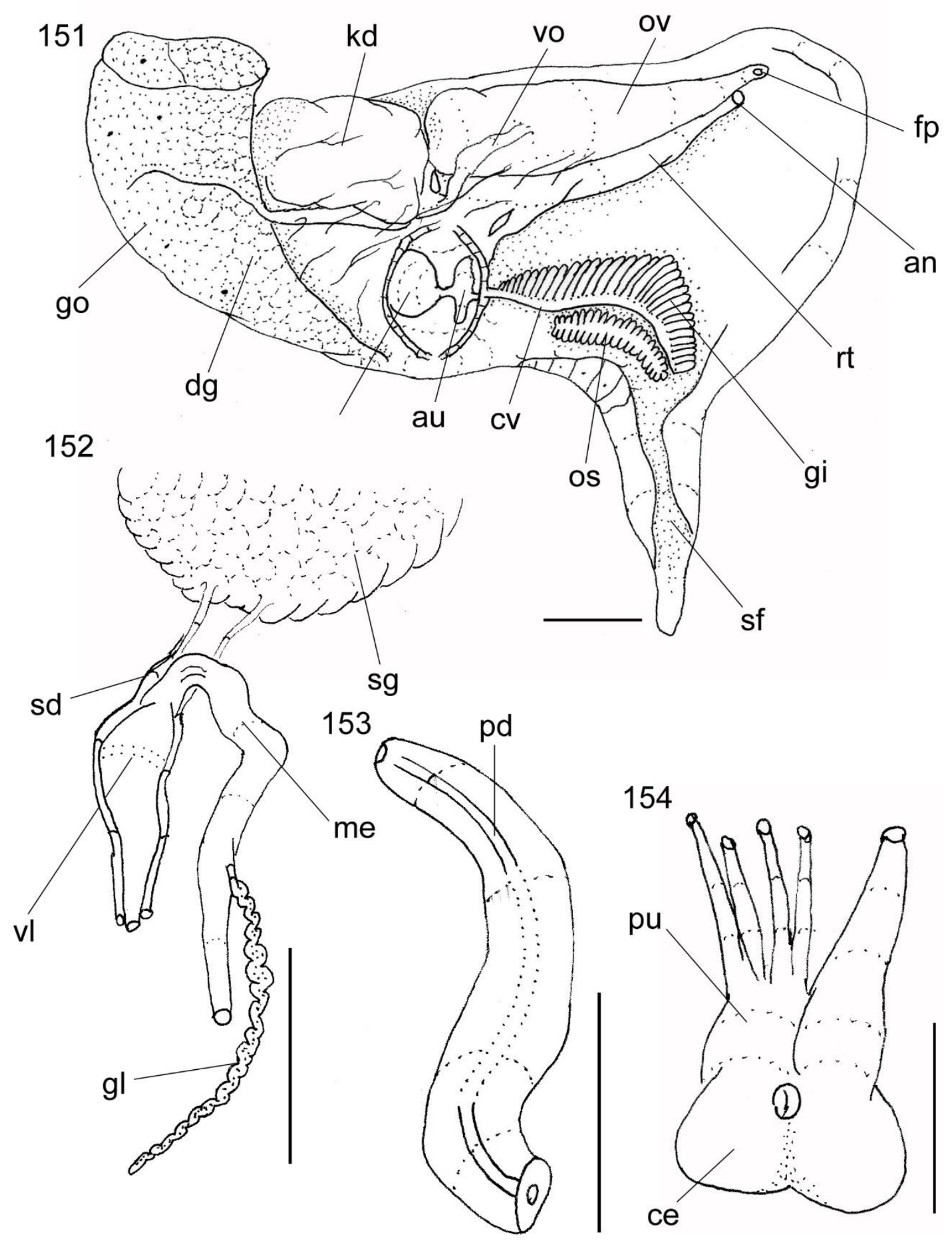

Figs. 151-154. Cyclope sp. Details of anatomy, Fig. 151: Pallial cavity roof, ventral view; Fig. 152: Detail of fore and midgut, associated structures also shown; Fig. 153: Penis, lateral left view; Fig. 154: Nerve ring, dorsal view. Scales $=2 \mathrm{~mm}$. 


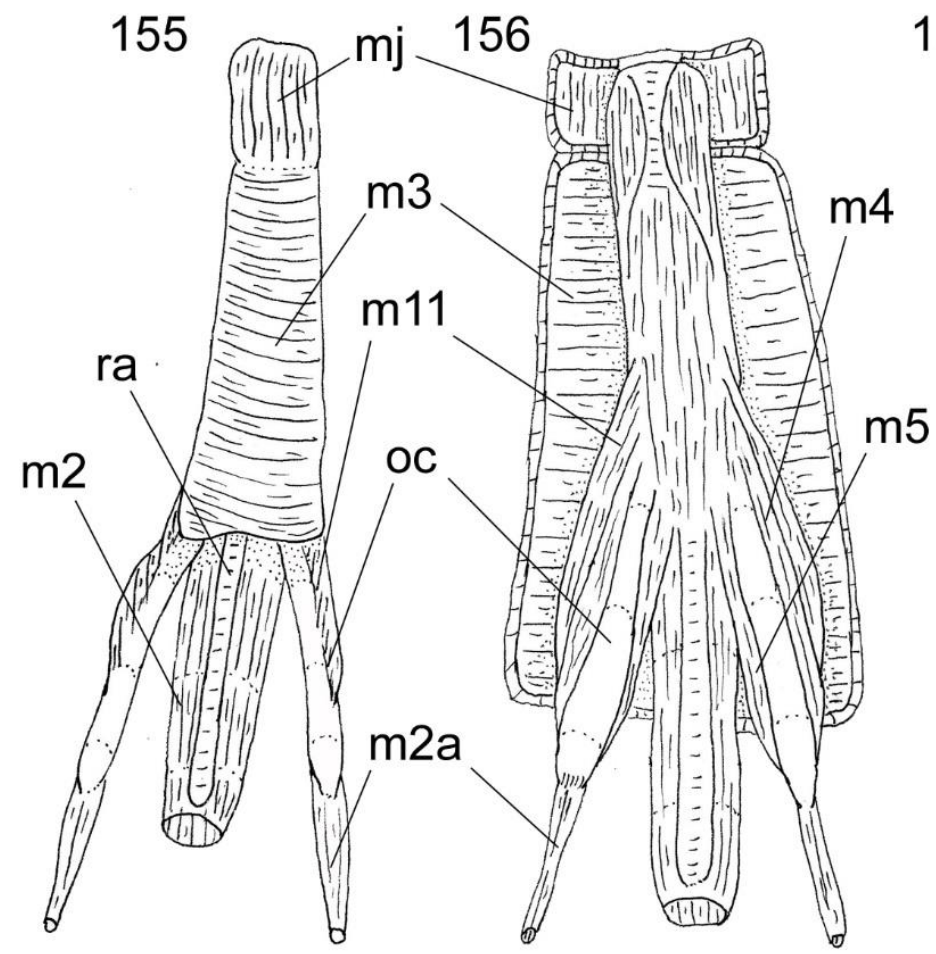

157

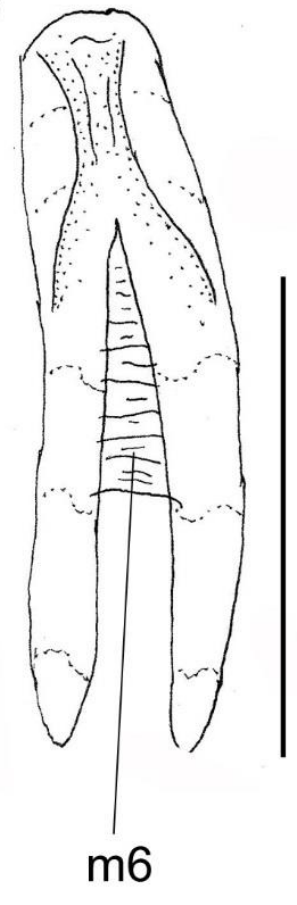

Figs. 155-157. Cyclope sp. Details of anatomy, Fig. 155: Odontophore, dorsal view, superficial layers showed; Fig. 156: Odontophore, dorsal view, superficial muscles dissected; Fig. 157: Odontophore cartilages, associated muscles shown 
Tribe Nassarini tribe nov.

Genus Nassarius Duméril, 1806

Type species: Buccinum arcularium (Linné, 1758) by monotypy.

\section{Nassarius arcularia (Roeding, 1798)}

Figs. 158-176.

Buccinum arcularium Linné, 1758.

Distorsio plicata Roeding, 1798: 133 (figs. 411, 412)

Nassa arcularia var. Spira cancellata Lamarck, 1816: 394 (fig. 2).

Buccinum obvelatum Deshayes, 1834: 66 (figs. 5, 6).

Buccinum pullus Kiener, 1834: 28 (figs. 114).

Buccinum rumphii Deshayes \& Edwards, 1844: 10 (figs. 179) [nom B. rumphii Gmelin, 1791].

Nassa arcularia plicata Bolten, 1852: 79.

Nassa sulcifera Adams, 1852: 98 (aberrant spec.).

Nassa pulla Reeve, 1853: 4 (figs. 22a, b) [nom Buccinum pullus Linnaeus, 1758).

Nassa crispata Marrat, 1877: 14 (spec. Juv.).

Nassa arcularia Melvill \& Sykes, 1898: 37; Melvill \& Standen, 1901: 409; Dautzenberg, 1929: 407; Kensley, 1973: 160 (586).

Nassa pulla var. minor Smith, 1912: 77 (nom Marrat, 1877).

Nassarius arcularia Cox, 1927: 18 (figs 13a, b).

Nassarius pullus Melvill, 1928: 106; Bisacchi, 1930: 47 (figs 1-3); Kaicher, 1957: pl. 7 (fig. 6); Spry, 1961: 23 (pl. 7, fig. 73).

Nassarius arcularia Bisacchi, 1930: 44.

Nassa rumphii Hombron \&Jacquinot, 1938: 184 (pl. 8, figs. 8a, b).

Nassarius arcularia (Roeding) Cernohorsky, 1972: 129 (figs. 3, 4); Barash \& Danin: 95 (fig. 10).

Shell (Figs. 158-161). Ovate, about twice long as wide, with 6 convex whorls; color beige to gray, with cream and brow bands in the middle region of whorls. Protoconch small, smooth, white, with about two whorls; transition to teleoconch hardly indicated by a depression and by the difference of sculpturing. Teleoconch sculpture composed of white axial ribs along entire surface and cream spiral nodules near the sutures, spire angle $\sim 50^{\circ}$, shoulder absent. Aperture prosocline, rounded, posteriorly acuminate, ca. 1/2 of shell length; color white with cream spots; outer lip thick, palatal wall smooth; parietal rib strongly present; Parietal shield strongly developed, covering about $1 / 2$ of ventral surface of body whorl; Anal notch well marked. Siphonal canal short, strong, deep, narrow ( 1/3 of aperture length) and dorsally recurved.

Head-foot (Figs. 164, 165). Pallial cavity covering 1/2 of total animal length; muscular siphon located on left, length $\sim 1 / 3$ of head-foot length. Head protruded; tentacles separated from each other, elongated and narrow, $3 \mathrm{x}$ as long as head; eyes 
pedunculated, located in medium region of tentacles. Foot small, occupying half of body whorl (retracted), flat, bearing a pair of medium metapodial tentacles; pedal gland located in anterior edge of foot, forming a groove, extending to dorsum of foot (propodium). Opercular pad occupying $~ 1 / 8$ of dorsal area of foot, oval. Penis originated in right lateral region, posterior to cephalic base, at level of mantle edge. Columellar muscle small and broad, 1/2 whorl long. Haemocoel long and broad, extending dorsally along center of foot and columellar muscle, $2 \mathrm{x}$ as long as wide.

Operculum (Fig. 162). Medium size, ovate, horny, pale orange; occupying almost entire aperture. Nucleus terminal, inferior. Outer surface with normal concentric growth lines, forming undulations. Scar elliptical, occupying about $2 / 3$ of inner surface, located close to edge of foot; expansions in the form of spines on both sides, left and right.

Mantle organs (Figs. 166, 167). Mantle cavity covering $\sim 1$ whorl. Siphon width 1/4 of mantle cavity width, length $1 / 2$ of mantle cavity length. Right base of siphon high, width about three times as mantle edge width; left base low ending gradually. Osphradium long and wide, elliptical, length $2 / 3$ of pallial cavity length, width $\sim 1 / 5$ of its width. Osphradial filaments short, broad. Ctenidial vein (efferent branchial vessel) uniformly narrow along its length. Gill long and wide, occupying 95\% of length and 1/3 of width of pallial cavity. Anterior end of gill rounded, ending gradually, inserted directly into pallial cavity. Gill filaments increasing in size in middle region. Posterior end of gill tapered, located in posterior region of mantle cavity, inserted into pericardium. Gill filaments low and rounded. Hypobranchial gland strong glandular. Right side of pallial cavity almost entirely filled by gonoducts. Rectum long and thin, occupying $~ 2 / 3$ of pallial cavity width. Anus siphoned, distance between anus and mantle border 1/5 of total pallial cavity length. Anal gland absent.

Visceral mass (Figs. 166). About $21 / 2$ whorls posterior to mantle cavity. Digestive gland dark beige, occupying $\sim 80 \%$ of visceral mass, encircling stomach. Gonad orange with small black spots, located on columellar surface, posterior to stomach. Seminal vesicle of males located in anterior portion of gonad, $\sim 1 / 2$ of its size. Kidney occupying $\sim 1 / 2$ of visceral mass volume, located on right side of anterior visceral end. Stomach small, located half whorl in front of pallial cavity.

Circulatory and excretory systems (Fig. 166, 167). Reno-pericardial region occupying 1 whorl, adjacent to mantle cavity; square shaped. Pericardium occupying 1/6 of reno-pericardial region, posterior to gill; situated on left anterior margin of visceral mass. Auricle triangular membranous, anterior to ventricle; with three connections: on 
upper right side with kidney, on anterior right side with gill, and on posterior left side with ventricle. Ventricle four times as large as auricle, with common aorta in left posterior margin. Aorta thin, located along postero-left region of ventricle, anterior aorta with twice diameter of posterior aorta. Kidney occupying $1 / 4$ of pallial cavity length, renal lobe single, solid; efferent renal vessel located at its right portion. Nephridial gland not seen in detail. Nephrostome small, longitudinal slit, located in anterior region of membrane between kidney and pallial cavity.

Digestive system (Figs. 168-170, 172-175). Mouth longitudinal, narrow. Proboscis long and broad, occupying about $90 \%$ of haemocoel lenght. Rhynchodeal wall thick and membranous, involving $2 / 3$ of proboscis. Thick retractor muscles covering posterior end of proboscis. Salivary glands located at anterior portion of haemocoel, occupying $\sim 1 / 5$ of haemocoel volume, entirely involving nerve ring, middle esophagus and anterior portion of proboscis. Salivary ducts very narrow, running completely attached to anterior esophagus wall and, more anteriorly, inside dorsal wall of buccal cavity along the folds; opening very small, closed to the mouth. Valve of Leiblein medium, about 1/8 of proboscis volume, located in medium esophagus anterior to nervous ring, diameter about $1 / 5 \mathrm{x}$ of the medium esophagus, anterior region with transverse white band bearing long cilia, middle and posterior regions white, corresponding to inner gland that occupies most of inner surface. Gland of Leiblein narrow and elongated, 2 x longer than middle esophagus, becoming gradually narrower towards posterior, duct of Gland of Leiblein, long and narrow. Accessory salivary glands absent. Anterior esophagus thin uniformly narrow along its length; walls muscular, with two strong internal longitudinal folds, occupying entire length of proboscis. Middle esophagus with the same diameter of anterior esophagus; posterior esophagus $\sim 90 \%$ of total haemocoel lenght, thin, with constant diameter along its entire length, differentiation between middle and posterior esophagus not clear. Stomach and digestive gland ducts not analyzed in detail.

Odontophore and buccal mass muscles: $m j$, thick of perioral muscles connected on both sides, dorsal and ventral, surrounding odontophore cartilages long, about half of odontophore length,; $m 1$, jugal muscles, several tinny and thin fibers which connected odontophore in proboscis wall; $m 2$, pair of strong protractor muscles of buccal mass, originating on inner surface of proboscis, running along entire odontophore, inserting in anterior region of odontophore cartilages; $m 2 a$, pair of retractor muscles of buccal mass, originating on dorsal surface of haemocoel, inserting at end of posterior margin of odontophore cartilages; $m 2 b$, absent; $m 3$, long and cylindrical muscle forming outer wall 
of odontophore, with transverse fibers; $m 4$, pairs of strong radular dorsal tensor muscles covering almost entire surface of posterior portion of odontophore cartilages, originating outside edges of cartilage and inserting into subradular membrane; $m 5$, pair of auxiliary dorsal tensor muscles of radula, originating inside edges of cartilage, adjacent to $\mathrm{m} 4$ insertion; $m 6$, horizontal muscle, thick, connecting ventral edges of cartilages, running $\sim 2 / 3$ of their length; $m 8$, pair of elliptical muscles, $\sim 1 / 4$ of total length of odontophore, originating at anterior end of odontophore cartilages, running along ventral surface of odontophore, inserting on anterior ventral surface of cartilages; $m 11$, pair of ventral tensor muscles of radula, about $1 / 3$ of total odontophore length, originating at ventral-posterior end of cartilages, crossing ventrally entire odontophore, inserting into ventral posterior surface of radula. Additional odontophore structures: $b r$, subradular membrane, thin, strong and translucent, along entire length of radular ribbon, covering inner surface of odontophore cartilages; $o c$, odontophore cartilages, about $3 \mathrm{x}$ long as wide, inner ventral surface concave, $\sim 1 / 4$ of anterior end fused with each other; $r s$, radular sac thin-walled, cylindrical, located at posterior end of radula; $n r$, radular nucleus width $\sim 1 / 2$ of radular sac width.

Radular teeth (Fig. 163). Rachidian tooth wide, comb-like, occupying about half of radular width; base curved, width $\sim 3 \times$ its length; $\sim 14$ triangular, sharp pointed cusps of similar size, except for some diminishment towards the side; lateral tooth hook-like, with two cusps, base broad (equivalent to rachidian base width), obliquely disposed; main lateral cusp widely curved inwards, about as long as base; secondary cusp approximately 3/4 size of main lateral cusp; radula ribbon equal between males and females; jaws absent.

Genital system. Male (Fig. 171). Vas deferens narrow, simple, straight, running along ventral surface of kidney up to pallial cavity. Prostate totally closed (tubular), running thought right mantle edge, at $\sim 1 / 3$ of total pallial cavity length. Vas deferens anterior to prostate, straight, running immersed into integument of dorsum, next to mantle border and penis base. Penis broad, length $\sim 2 / 4$ of total head-foot length, dorso-ventrally flattened and with wide point at anterior half; base curved, apical region tapered. Penial duct straight, running through center of penis, closed (tubular). Penial aperture distal, slit, circunded by a dilated region.

Female (Figs. 166). Visceral oviduct narrow, straight, running along dorsal surface of kidney in first whorl of visceral mass, located in front of pallial cavity. Posterior region of pallial oviduct protruding into kidney, occupying $~ 2 / 3$ of length of pallial cavity and 1/5 of its width. Albumen gland posterior, whitish, thin-walled, occupying $~ 1 / 3$ of 
pallial oviduct. Capsule gland $\sim 2 / 3$ of oviduct, elongated, orange, thick-walled. Vaginal atrium thin, tubular, occupying 1/8 of oviduct; walls thick, muscular, female genital pore narrow. Bursa copulatrix absent. Cement gland absent.

Central nervous system (Fig. 176). Nerve ring located in ventral anterior proboscis region, occupying 1/12 of haemocoel volume, highly concentrated. Ganglia mostly fused, hard to distinguish from each other, somewhat asymmetrical. Pairs of pleural and cerebral ganglia fully fused with each other. Sub-esophageal not seen in detail. Esophageal aperture wide, central, located in midlle region of pleural and cerebral ganglia, occupying about 1/6 of surface of nerve ring. Statocysts not visualyzed.

Shell measurements (length $x$ width in $\mathrm{mm}$ ): $2{ }^{\lambda} 17.5 \mathrm{x} 11.8 ; 16 \times 9.2 ; 3 \circ 17.2 \mathrm{x}$ $10.8 ; 15.3 \times 10.1 ; 17.1 \times 10.3$.

Distribution: Red sea, Persian Gulf, Mauritius Island, Western Africa.

Habitat: Fine sand bottoms, infratidal.

Material examined: MZSP 99863; 2へ, 3 , Djibouti: Plage Blanc; (Coltro col., iii/2011). 


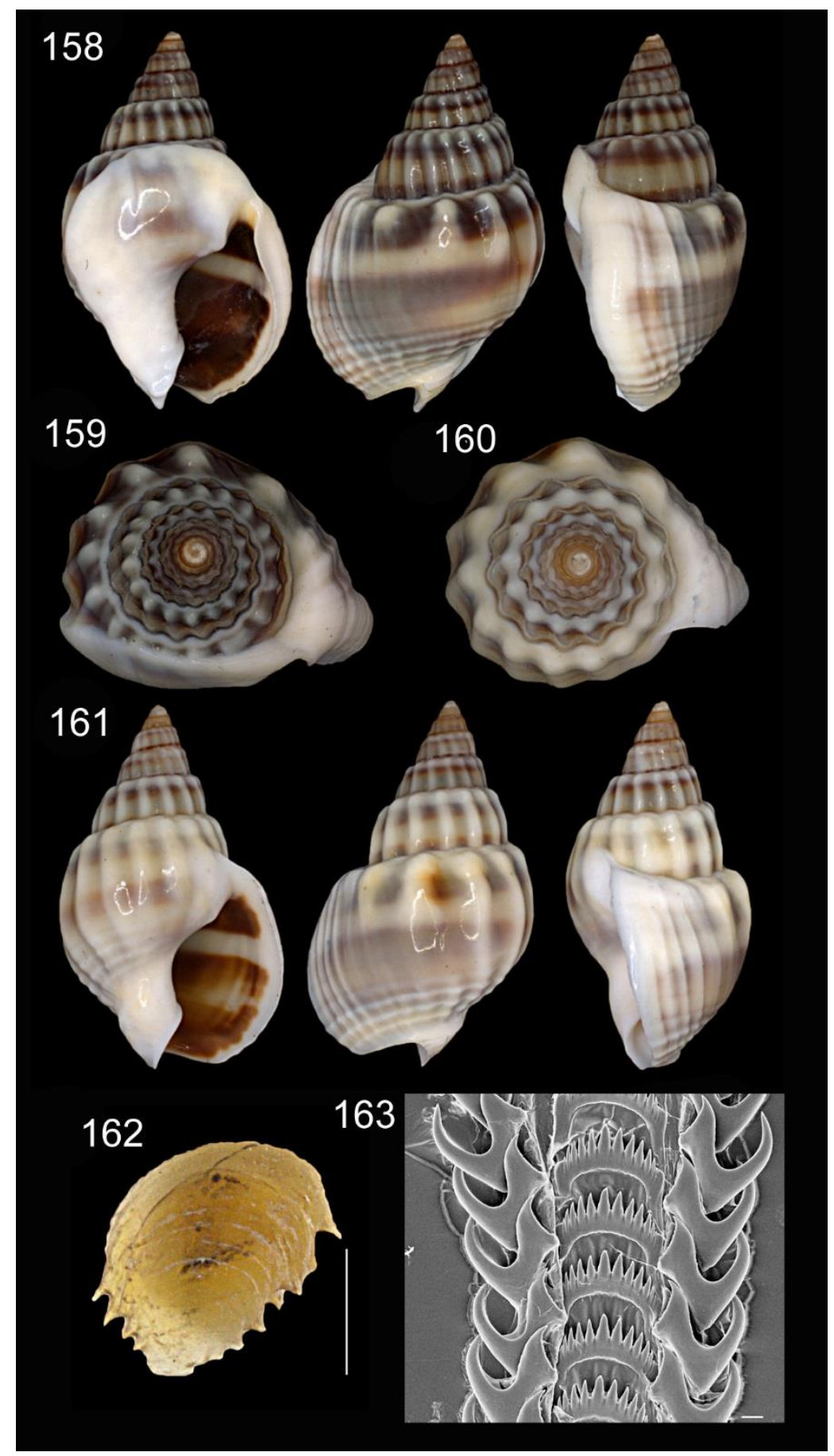

Figs. 158-163 Nassarius arcularia: MZSP 909863 으, shell, operculum and radula; Figs 158: Adult specimen, Shell apertural, dorsal and lateral views (L 15,6 mm); Fig. 159: Adult specimen, shell apical view; Fig. 160: Young specimen, shell apical view; Fig. 161: Young specimen, shell apertural, dorsal and lateral view (L 13,4); Fig. 162: Operculum dorsal view, scale = 2 mm; Fig. 163; SEM of radula: Panoramic view of middle portion, scale $=20 \mu \mathrm{m}$. 

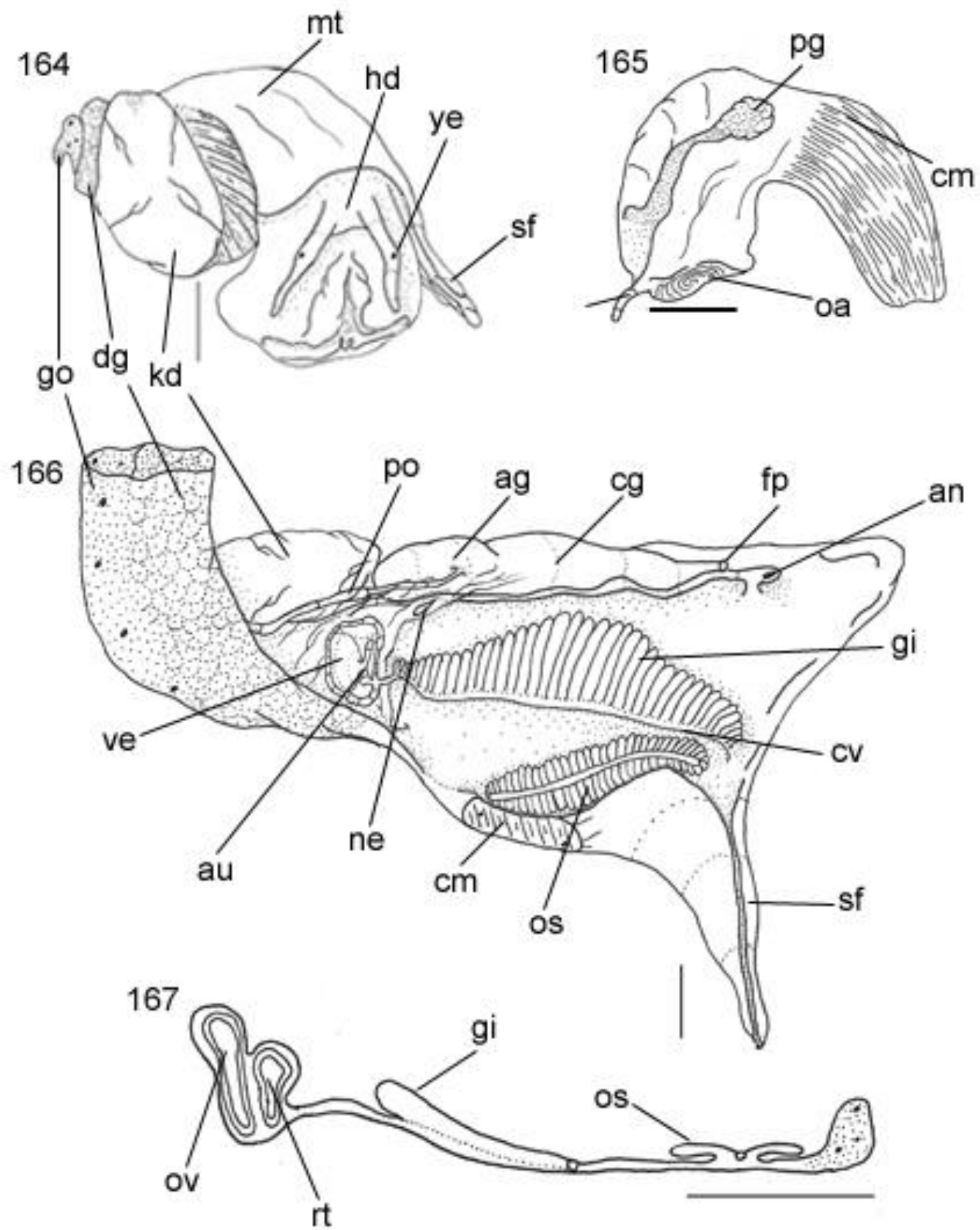

Figs. 164-167. Nassarius arcularia: Details of anatomy, Fig. 164: complete specimen extracted from shell (operculum removed), anterior-right view; Fig. 165: Foot of female, sagittal section; Fig. 166: Pallial cavity roof, transverse section at middle level of osphradium. Fig. 167: Pallial cavity roof, transverse section at middle level of osphradium. Scales $=2 \mathrm{~mm}$. 

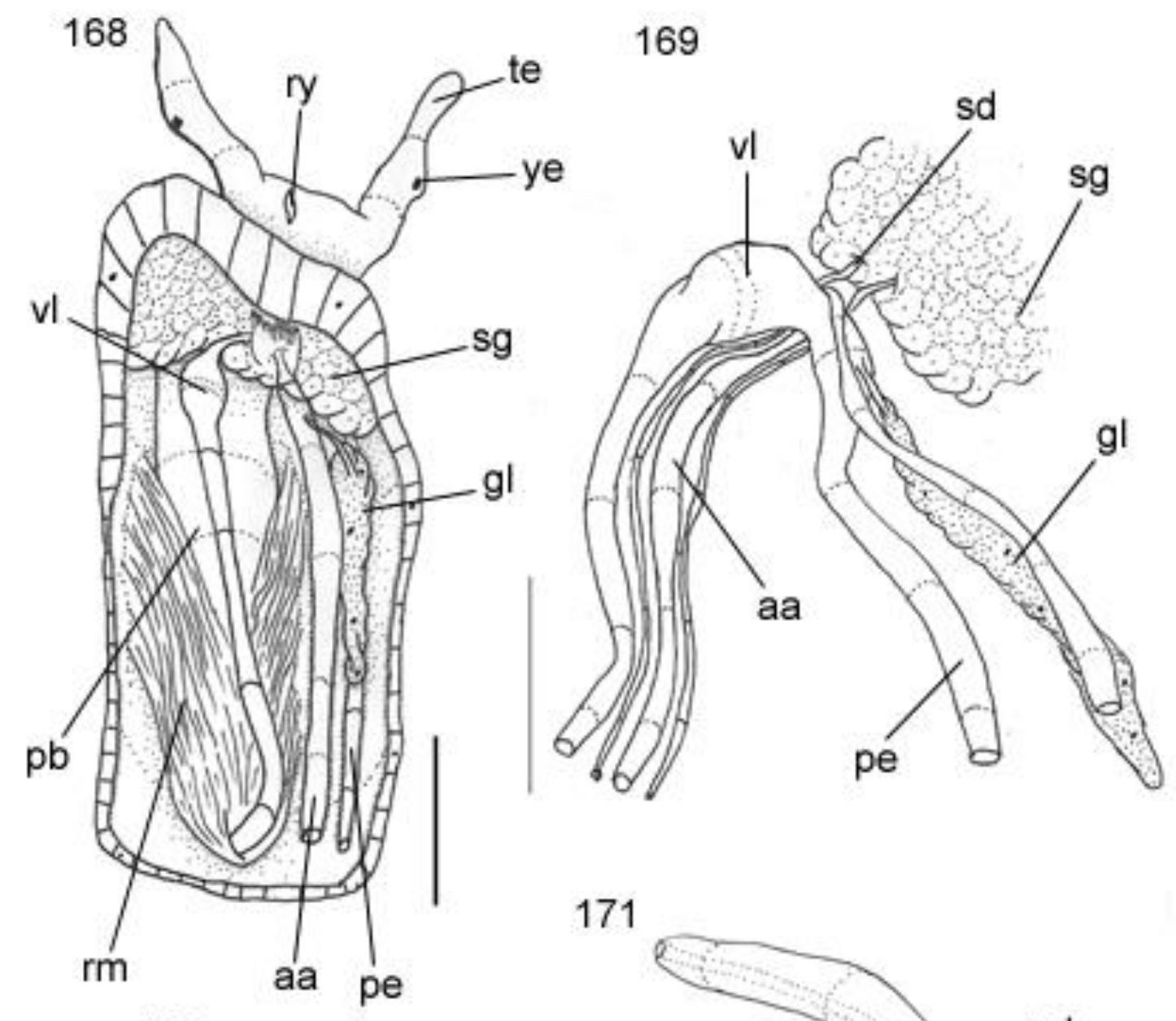

171
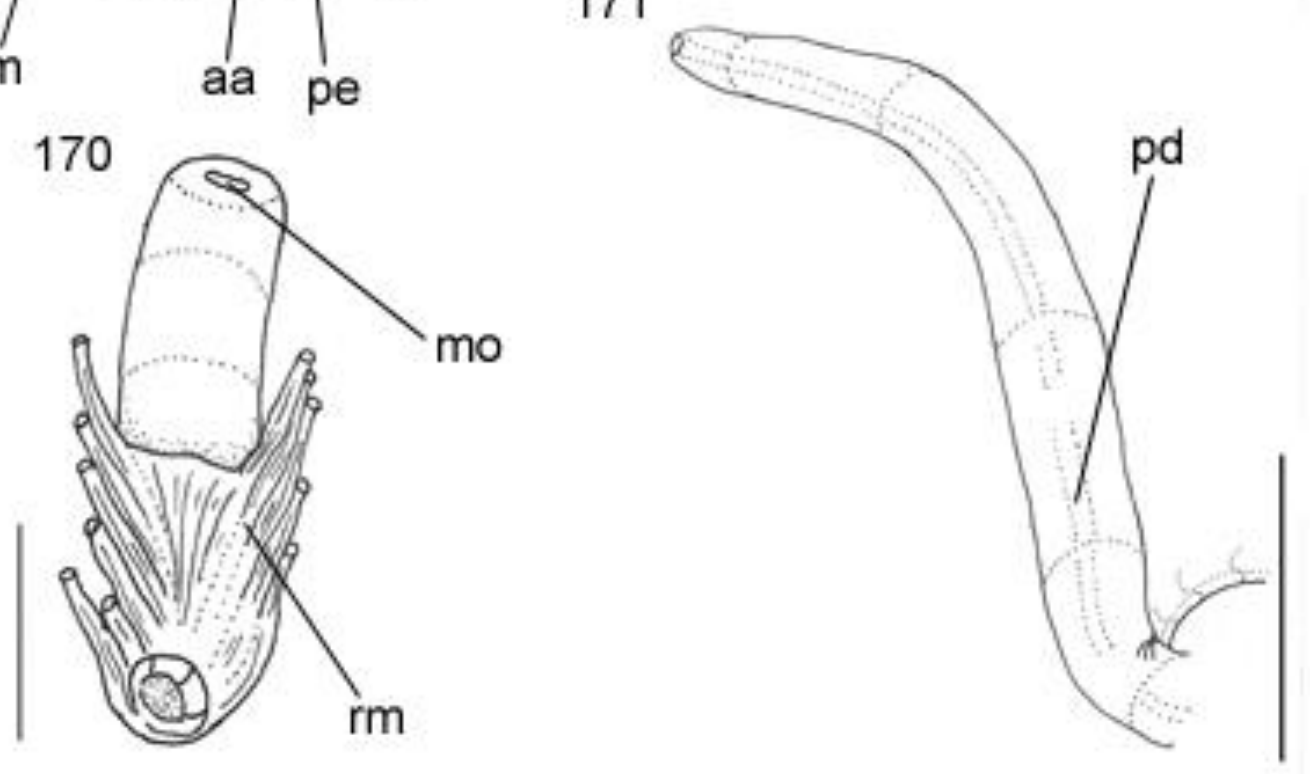

Figs. 168-171. Nassarius arcularia: Details of anatomy, Fig. 168: Head and haemocoel, ventral view, foot and columellar muscle removed; Fig. 169: Mid and anterior region of posterior esophagus and associated structures, showing valve and gland of Leiblein; Fig. 170: Proboscis, ventral view, retractor muscles showed; Fig. 171: Penis, ventral view. Scales $=2 \mathrm{~mm}$. 

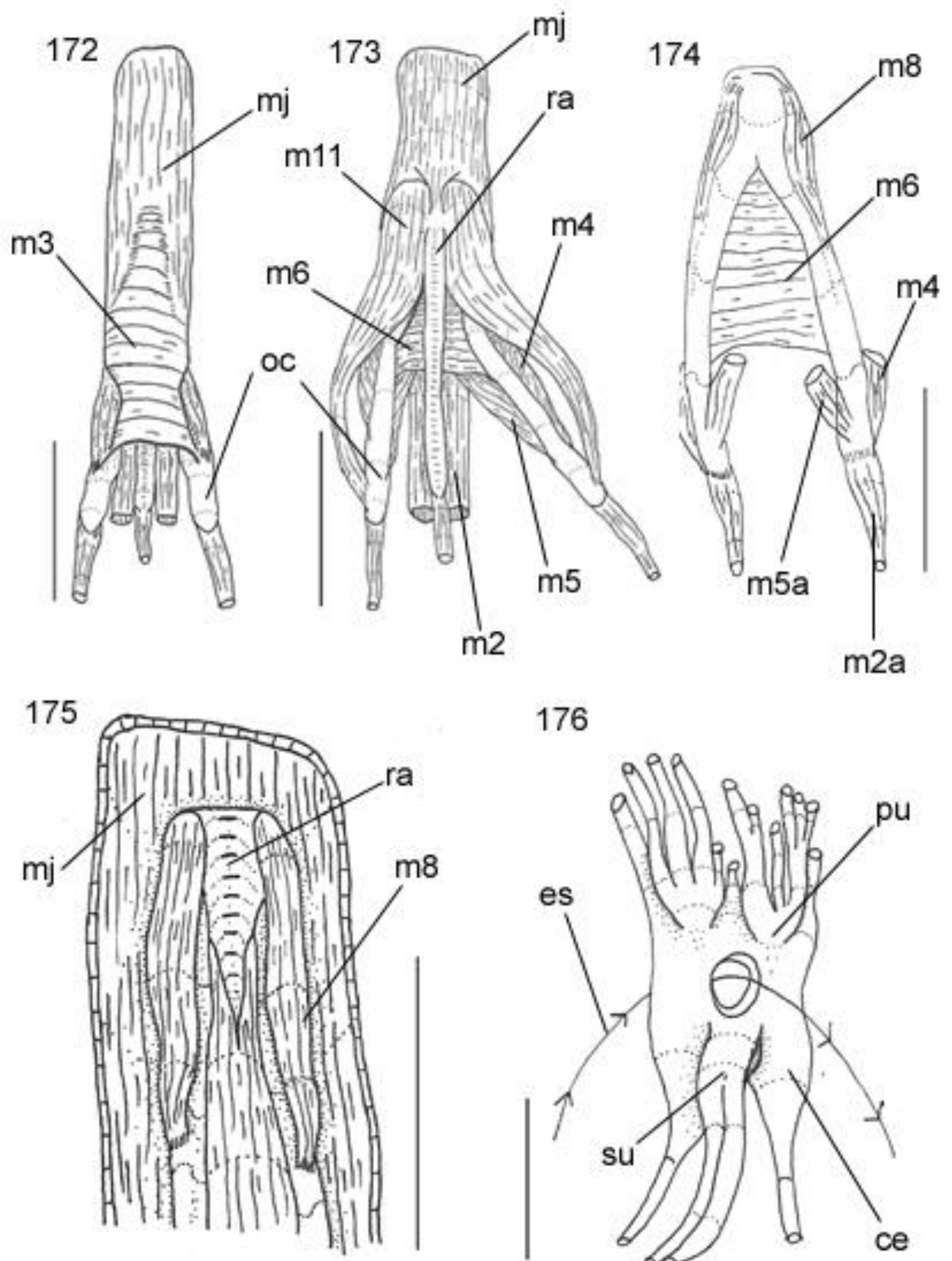

176

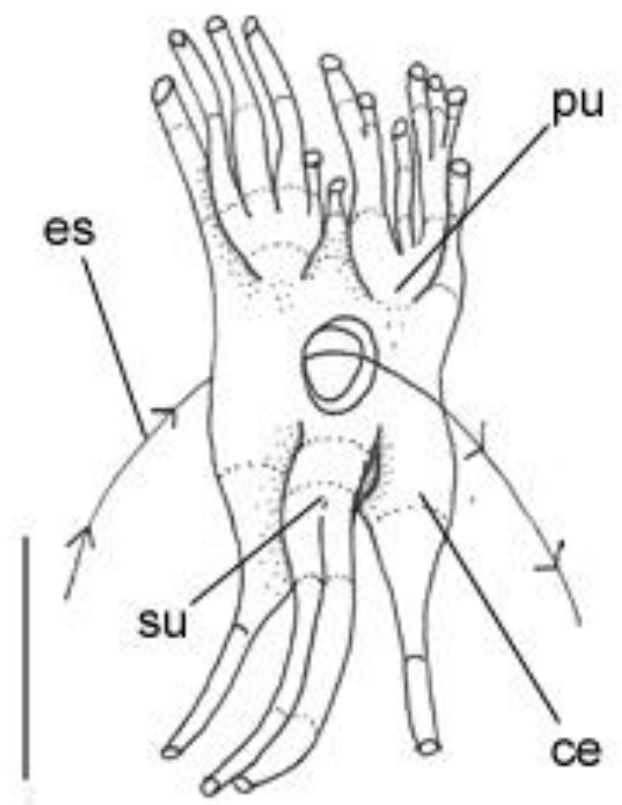

Figs. 172-176. Nassarius arcularia: Details of anatomy, Fig. 172: Odontophore, dorsal view, superficial layers showed; Fig. 173: Odontophore, dorsal view, superficial muscles dissected; Fig. 174: Odontophore cartilages, dorsal view, some adjacent muscles shown; Fig. 175: Foregut. Detail of mj muscle;

Fig. 176: Nerve ring, dorsal view. Scales $=2 \mathrm{~mm}$. 


\section{Nassarius scabriusculus (Powys, 1835)}

Figs. 177-193.

Nassa scabriuscula Powys, 1835: 95.

Nassa colaria Adams, 1852: 283.

Shell (Figs. 177, 178). Ovate, about twice as long as wide, with 7 convex whorls; color opaque gray with beige bands near the sutures. Protoconch small, smooth, beige, with about two whorls, commonly eroded; transition to teleoconch hardly indicated by a depression and by the difference of sculpturing. Teleoconch sculpture composed of axial small ribs along entire surface and beige spiral nodules near the sutures, spire angle $\sim 60^{\circ}$, shoulder absent. Aperture prosocline, rounded, posteriorly acuminate, ca. 1/3 of shell length; color pale orange; outer lip thick, palatal wall smooth; parietal rib strongly present; Parietal shield strongly developed, covering about $1 / 2$ of ventral surface of body whorl; Anal notch averagely marked. Siphonal canal short, strong, deep, narrow ( $\sim 1 / 3$ of aperture length) and dorsally recurved.

Head-foot (Figs. 181). Pallial cavity covering 1/2 of total animal length; muscular siphon located on left, length $\sim 1 / 5$ of head-foot length. Head protruded, socket-like; tentacles well-separated from each other, elongated and narrow, twice as long as head; eyes simple, located in medium region of tentacles. Foot large, occupying whole body whorl (retracted), flat, bearing a pair of small metapodial tentacles; pedal gland located in anterior edge of foot, forming a groove, extending from dorsum of foot (propodium) to sole. Opercular pad occupying 1/30 of dorsal area of foot, oval. Penis originated in right lateral region, posterior to cephalic base, at level of mantle edge. Columellar muscle wide and broad, one whorl long. Haemocoel long and thin, extending dorsally along center of foot and columellar muscle, $3 \mathrm{x}$ as long as wide.

Operculum (Fig. 179). Medium size, elliptical, horny, pale brown; occupying almost entire aperture. Nucleus terminal, inferior. Outer surface with normal concentric growth lines, forming undulations. Scar elliptical, occupying about $2 / 3$ of inner surface, located close to edge of foot; expansions in the form of spines on both sides, left and right.

Mantle organs (Figs. 183, 184). Mantle cavity covering 1 whorl. Siphon width $1 / 3$ of mantle cavity width, length $1 / 5$ of mantle cavity length. Right base of siphon high, width twice as mantle edge width; left base high ending in a fold. Osphradium long and narrow, elliptical, length $1 / 2$ of pallial cavity length, width $\sim 1 / 7$ of its width. Osphradial filaments short, width similar to mantle edge. Ctenidial vein (efferent branchial vessel) uniformly narrow along its length. Gill long and narrow, occupying 80\% of length and 
1/5 of width of pallial cavity. Anterior end of gill rounded, ending gradually, inserted directly into pallial cavity. Gill filaments with constant diameter throughout its length. Posterior end of gill rounded, located in posterior region of mantle cavity, inserted into pericardium. Gill filaments low and rounded. Hypobranchial gland strong glandular. Right side of pallial cavity almost entirely filled by gonoducts. Rectum long and thin, occupying 1/6 of pallial cavity width. Anus siphoned, distance between anus and mantle border $1 / 9$ of total pallial cavity length. Anal gland absent.

Visceral mass (Fig. 183). About 3 whorls posterior to mantle cavity. Digestive gland dark beige, occupying $\sim 80 \%$ of visceral mass, encircling stomach. Gonad orange with small black spots, located on columellar surface, posterior to stomach. Seminal vesicle of males located in anterior portion of gonad, $\sim 1 / 2$ of its size. Kidney occupying $\sim 1 / 2$ of visceral mass volume, located on right side of anterior visceral end. Stomach small, located half whorl in front of pallial cavity.

Circulatory and excretory systems (Figs. 183, 184, 187). Reno-pericardial region occupying 1 whorl, adjacent to mantle cavity; oval shaped. Pericardium occupying 1/6 of reno-pericardial region, posterior to gill; situated on left anterior margin of visceral mass. Auricle triangular membranous, anterior to ventricle; with three connections: on upper right side with kidney, on anterior right side with gill, and on posterior left side with ventricle. Ventricle five times as large as auricle, with common aorta in left posterior margin. Aorta wide, located along postero-left region of ventricle, anterior aorta with twice diameter of posterior aorta (Fig.). Kidney occupying 1/5 of pallial cavity, renal lobe single, solid; efferent renal vessel located at its right portion. Nephridial gland well developed, about 2/3 of kidney lenght. Nephrostome small, longitudinal slit, located in anterior region of membrane between kidney and pallial cavity.

Digestive system (Figs. 182, 186, 188-191). Mouth longitudinal, narrow. Proboscis long and thin, occupying about $890 \%$ of haemocoel lenght. Rhynchodeal wall thick and membranous, involving $2 / 3$ of proboscis. Thick retractor muscles covering posterior end of proboscis. Salivary glands located at anterior portion of haemocoel, occupying $~ 1 / 4$ of haemocoel volume, entirely involving nerve ring, middle esophagus and anterior portion of proboscis. Salivary ducts very narrow, running completely attached to anterior esophagus wall and, more anteriorly, inside lateral walls of buccal cavity; opening very small, closed to the mouth. Valve of Leiblein small, about 1/8 of odontophore volume, located in medium esophagus anterior to nervous ring, diameter twice of the medium esophagus, anterior region with transverse white band bearing long 
cilia, middle and posterior regions white, corresponding to inner gland that occupies most of inner surface; bypass not seen. Gland of Leiblein narrow and elongated, $\sim 3 \mathrm{x}$ longer than middle esophagus, becoming gradually narrower towards posterior, duct of Gland of Leiblein, long and narrow. Accessory salivary glands absent. Anterior esophagus thin with bulging in the anterior region; walls muscular, with weakly internal longitudinal folds, occupying entire length of proboscis. Middle esophagus with the same diameter of anterior esophagus, and approximately of half length; posterior esophagus $\sim 90 \%$ of total haemocoel lenght, thin, with constant diameter along its entire length, differentiation between middle and posterior esophagus not clear. Stomach oval, as blind sac, located half whorl posterior to kidney; inner surface entirely pleated, typhlosole absent; digestive gland ducts not analyzed in detail.

Odontophore and buccal mass muscles: $m j$, thick pairs of perioral muscles connected on both sides, dorsal and ventral, surrounding odontophore cartilages; $m 1$, jugal muscles, several tinny and thin fibers which connected odontophore in proboscis wall; $m 2$, strong protractor muscles of buccal mass, originating on inner surface of proboscis, running along entire odontophore, inserting in anterior region of odontophore cartilages; $m 2 a$, pair of retractor muscles of buccal mass, originating on dorsal surface of haemocoel, inserting at end of posterior margin of odontophore cartilages; $m 2 b$, absent; $m 3$, long and cylindrical muscle forming outer wall of odontophore, with transverse fibers; $m 4$, pairs of strong radular dorsal tensor muscles covering almost entire surface of posterior portion of odontophore cartilages, originating outside edges of cartilage and inserting into subradular membrane; $m 5$, pair of auxiliary dorsal tensor muscles of radula, originating inside edges of cartilage, adjacent to $\mathrm{m} 4$ insertion; $m 6$, horizontal muscle, thick, connecting ventral edges of cartilages, running $~ 2 / 3$ of their length; $m 8$, pair of long elliptical muscles, $\sim 1 / 3$ of total length of odontophore, originating at anterior end of odontophore cartilages, running along ventral surface of odontophore, inserting on anterior ventral surface of cartilages; $m 11$, pair of ventral tensor muscles of radula elongated, about $2 / 3$ of total odontophore length, originating at ventral-posterior end of cartilages, crossing ventrally entire odontophore, inserting into ventral posterior surface of radula. Additional odontophore structures: $b r$, subradular membrane, thin, strong and translucent, along entire length of radular ribbon, covering inner surface of odontophore cartilages; $o c$, odontophore cartilages, about 4 times as long as wide, inner ventral surface concave, $\sim 1 / 4$ of anterior end fused with each other, $\sim 1 / 3$ of anterior region, concave, 
involving radular ribbon; $r s$, radular sac thin-walled, cylindrical, located at posterior end of radula; $n r$, radular nucleus width $\sim 1 / 2$ of radular sac width.

Radular teeth (Fig. 180). Rachidian tooth wide, comb-like, occupying about half of radular width; base curved, width $\sim 3 \times$ its length; $\sim 14$ triangular, sharp pointed cusps of similar size, except for some diminishment towards the side; lateral tooth hook-like, with two cusps, base broad (equivalent to rachidian base width), obliquely disposed; main lateral cusp widely curved inwards, about as long as base; secondary cusp approximately 3/4 size of main lateral cusp; radula ribbon equal between males and females; jaws absent.

Genital system. Male (Fig. 183, 192). Vas deferens narrow, simple, straight, running along ventral surface of kidney up to pallial cavity. Prostate totally closed (tubular), running thought right mantle edge, at $\sim 1 / 3$ of total pallial cavity length. Vas deferens anterior to prostate, straight, running immersed into integument of dorsum, next to mantle border and penis base. Penis slender, length $~ 2 / 4$ of total head-foot length, cylindrical and with wide point at anterior half; base curved, apical region slender and pointed. Penial duct straight, running through center of penis, closed (tubular). Penial aperture distal, ventral, small.

Female (Figs). Not visualized

Central nervous system (Fig. 193). Nerve ring located in ventral middle proboscis region, occupying $~ 1 / 12$ of haemocoel volume, highly concentrated. Ganglia mostly fused, hard to distinguish from each other, somewhat asymmetrical. Pairs of pleural and cerebral ganglia fully fused with each other. Pair of Buccal ganglia small, about half of pleural ganglia, located on ventral surface of pleural ganglia, connected by a thin commissure. Sub-esophageal ganglion about the same size of cerebral ganglion. Esophageal aperture small, posterior, located in pleural ganglia, occupying about 1/9 of ventral surface of nerve ring. Pair of small Statocysts located in ventral surface of cerebral ganglia.

Shell measurements (length $x$ width in $\mathrm{mm}$ ): $2 \widehat{\bigcirc} 23.57$ x 15.27; 21.33 x 14.47.

Distribution: El Salvador, Panamá

Habitat: Fine sand bottoms, infratidal.

Material examined: MZSP 78405; 20`, Panamá; Playa Bique, $08^{\circ} 52^{\prime}$ N, 79³9’ W, (Simone col., 31/i/2006). 


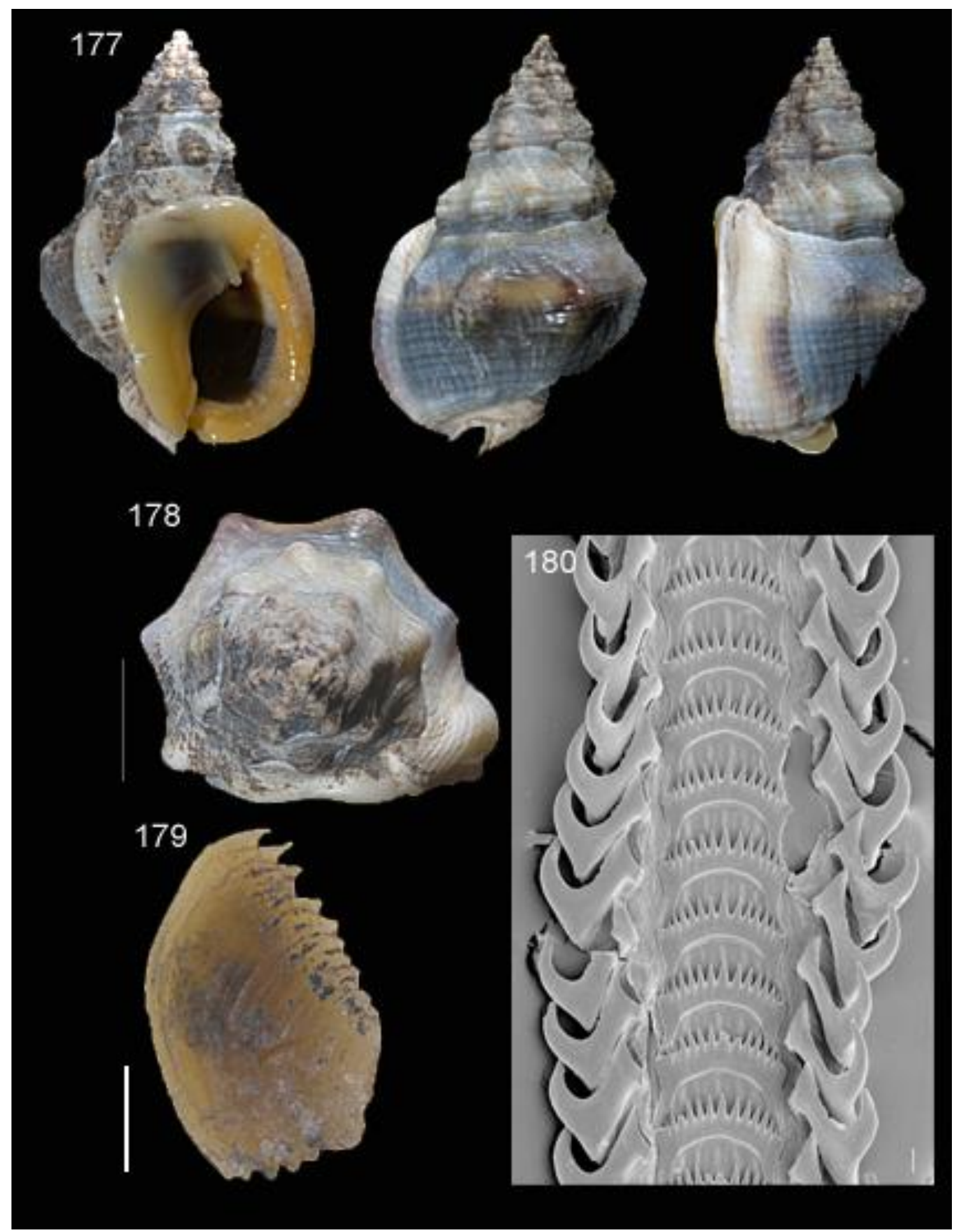

Figs. 177-180. Nassarius scabriusculus: MZSP 78405 ㅇ, shell, operculum and radula; Figs 177: Adult specimen, Shell apertural, dorsal and lateral view (L 21,33 mm); Fig. 178: shell apical view; Fig. 179: Operculum dorsal view, scale $=2 \mathrm{~mm}$; Fig. 180; SEM of radula: Panoramic view of middle portion, scale $=30 \mu \mathrm{m}$. 


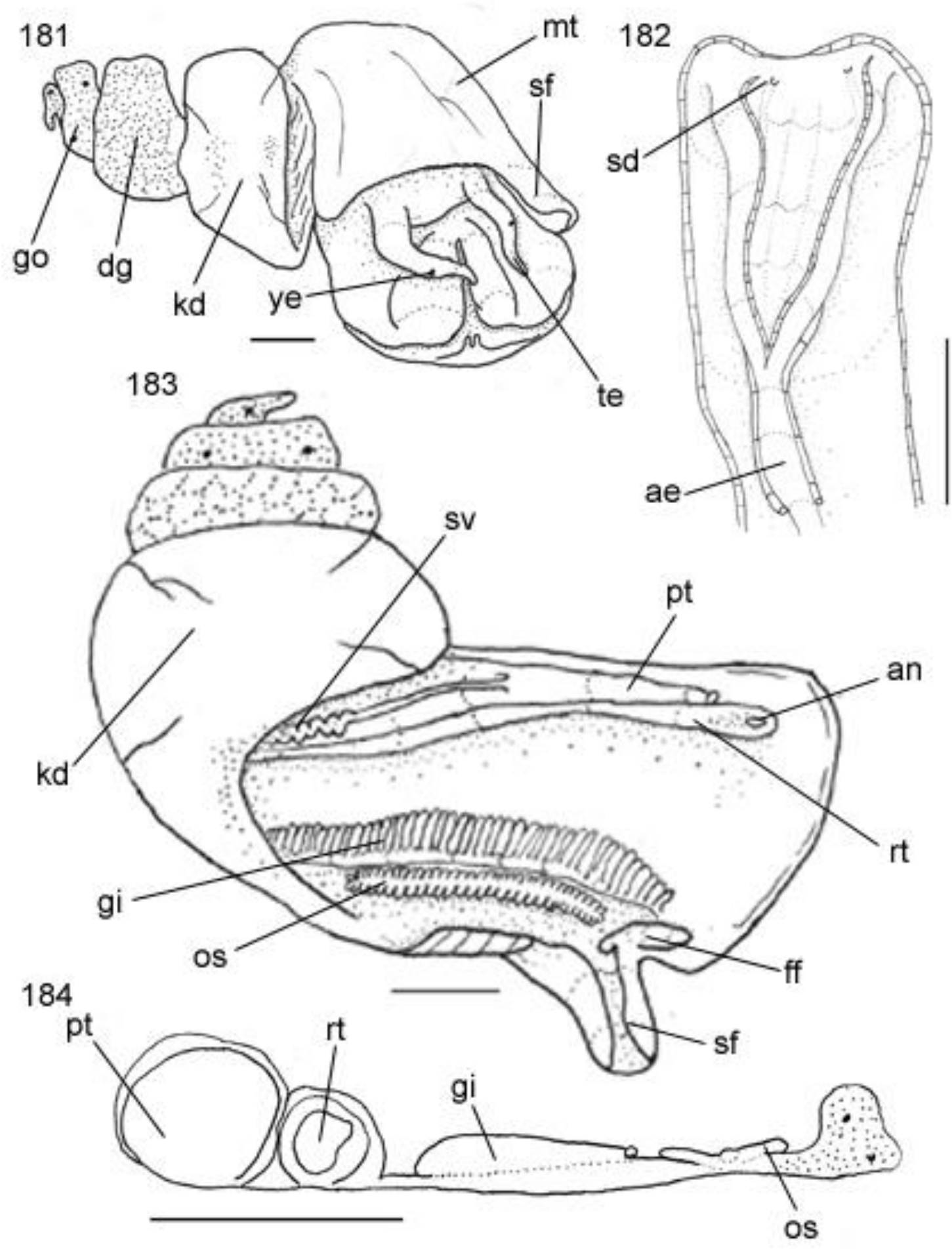

Figs. 181-184. Nassarius scabriusculus: Details of anatomy, Fig. 181: complete specimen extracted from shell (operculum removed), anterior-right view; Fig. 182: Proboscis and anterior esophagus opened longitudinally, showing salivary ducts and their apertures; Fig. 183: Pallial cavity roof, ventral view; Fig. 184: Pallial cavity roof, transverse section at middle level of osphradium. Scales $=2 \mathrm{~mm}$. 


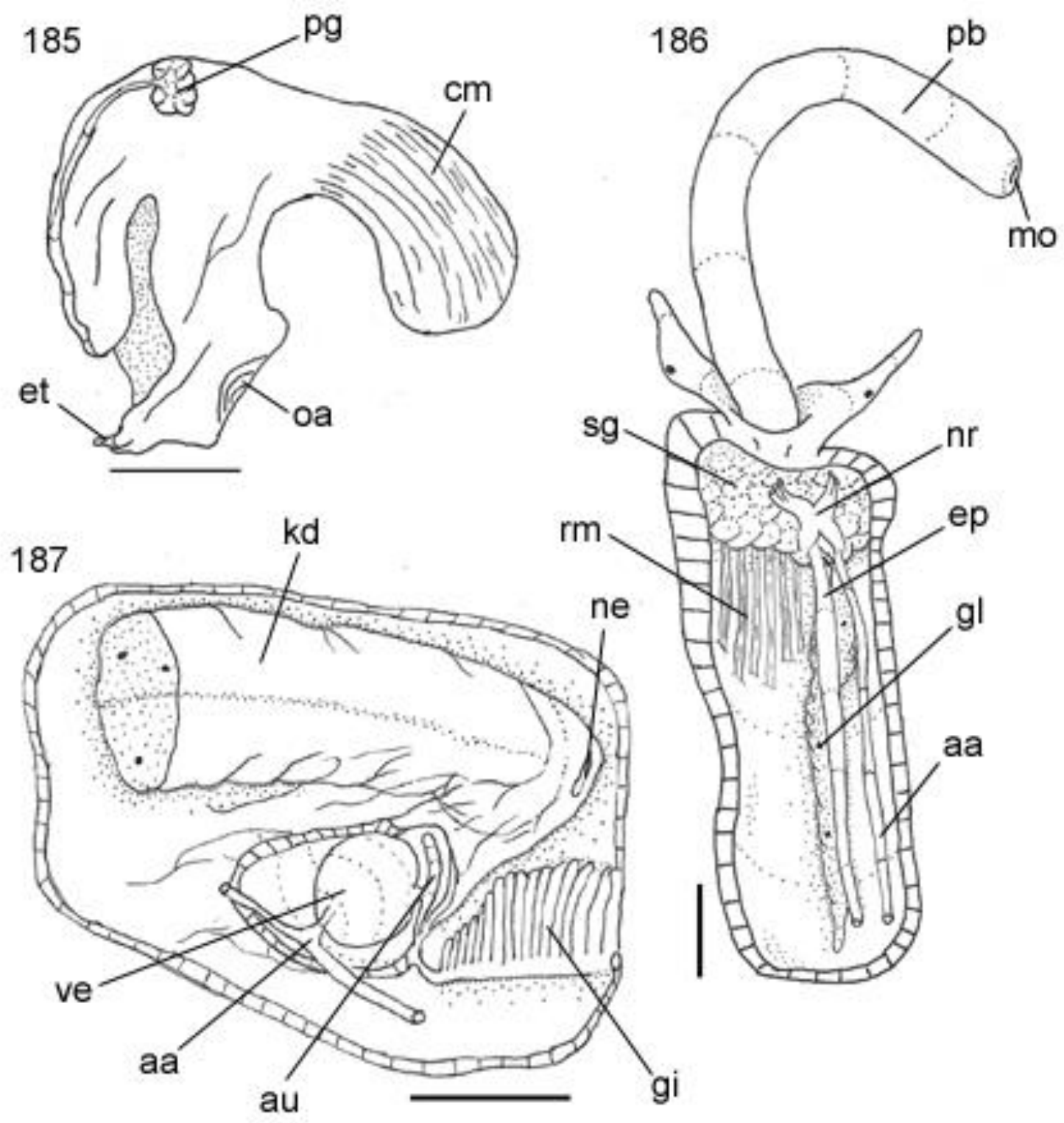

Figs. 185-187. Nassarius scabriusculus: Details of anatomy, Fig. 185: Foot of female, sagittal section; Fig. 186: Head and haemocoel, ventral view, foot and columellar muscle removed; Fig. 187: Detail of Circulatory and excretory systems. Scales $=2 \mathrm{~mm}$. 


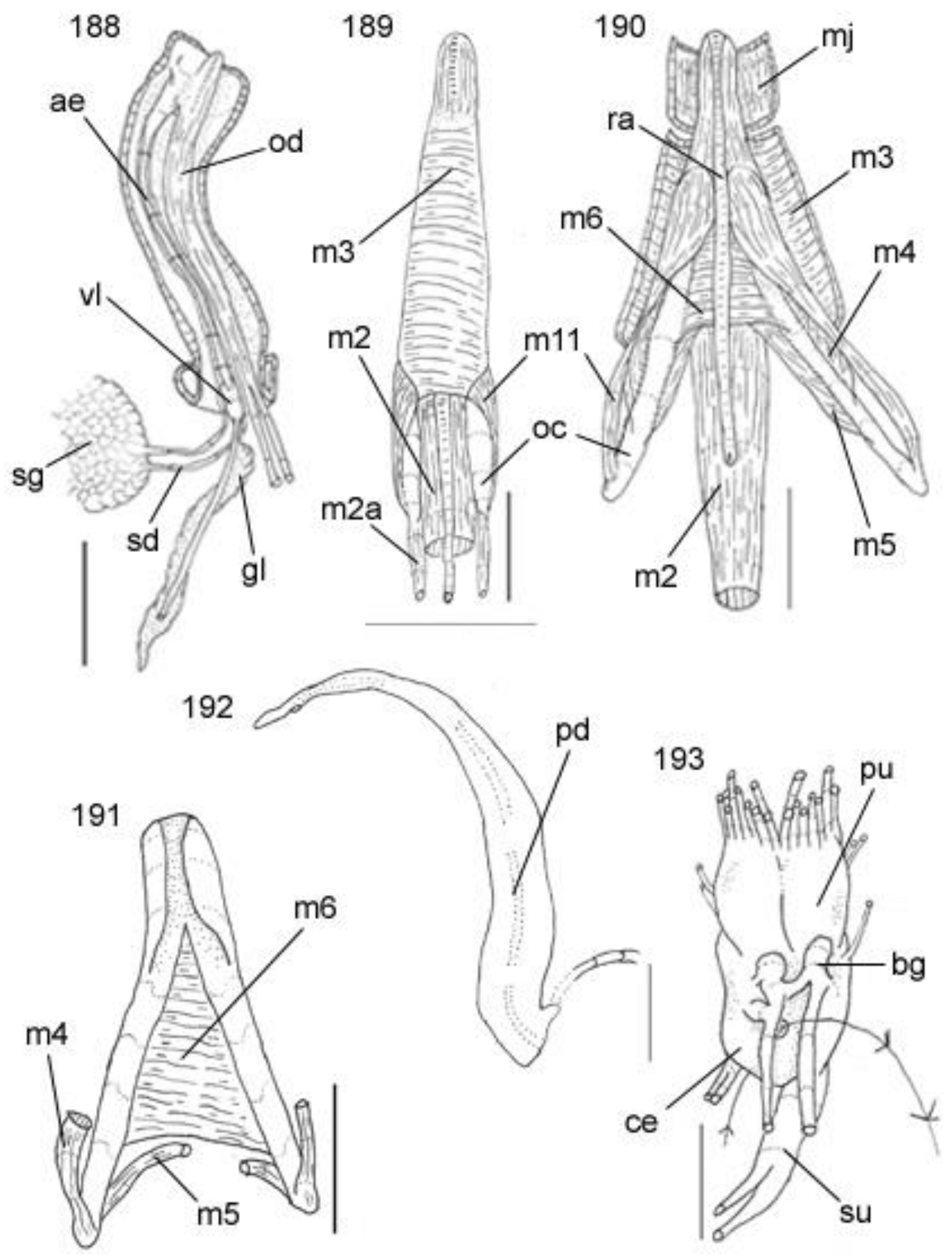

Figs. 188-193. Nassarius scabriusculus: Details of anatomy, Fig.188: Detail of fore and midgut, associated structures also shown; Fig. 189: Odontophore, dorsal view, superficial layers showed; Fig. 190: Odontophore, dorsal view, superficial muscles dissected; Fig. 191: Odontophore cartilages, associated muscles shown; Fig. 192: Penis, lateral left view; Fig. 193 Nerve ring, dorsal view. Scales = 2 mm. 


\section{Nassarius paucicostatus (Marrat, 1877)}

Figs. 194-195.

Nassa paucicostata Marrat, 1877: 11.

Shell (Figs. 194, 195). Fusiform, twice as long as wide, with 5 or 6 convex whorls; outline conic; color white with light brown spiral bands medially and near sutures. Protoconch wide, smooth, glossy, cream color, with 5 1/2 whorls; transition to teleoconch distinguishable as a subtle change in color and texture. Teleoconch sculpture consisting of spiral cords and longitudinal ribs along entire surface and whorls, sutures well demarcated. Spire tall, $\sim 2 / 3$ of total length; spire angle $\sim 53^{\circ}$. Aperture prosocline, rounded, posteriorly acuminate, $\sim 1 / 3$ of shell area; color white, with light brown bands internally and on the edge of outer lip; outer lip thin; aperture inner surface plicated; inner lip ornamented by 2 thin folds, short; Parietal shield absent; anal notch absent. Siphonal canal straight, short, strong, deep and narrow, $\sim 1 / 3$ of aperture length.

Shell measurements (length $x$ width in $\mathrm{mm}$ ): 6.4 x 4.14 .

Distribution: Caribean sea, Gulf of Mexico to off Bahamas, North of Brazil.

Habitat: Fine sand bottoms, infratidal.

Material examined: MZSP 92843; Brasil, Maranhão, 01 49’ S, 42 55’ W, 62 m depth (Amorim do vale col., 2009). 


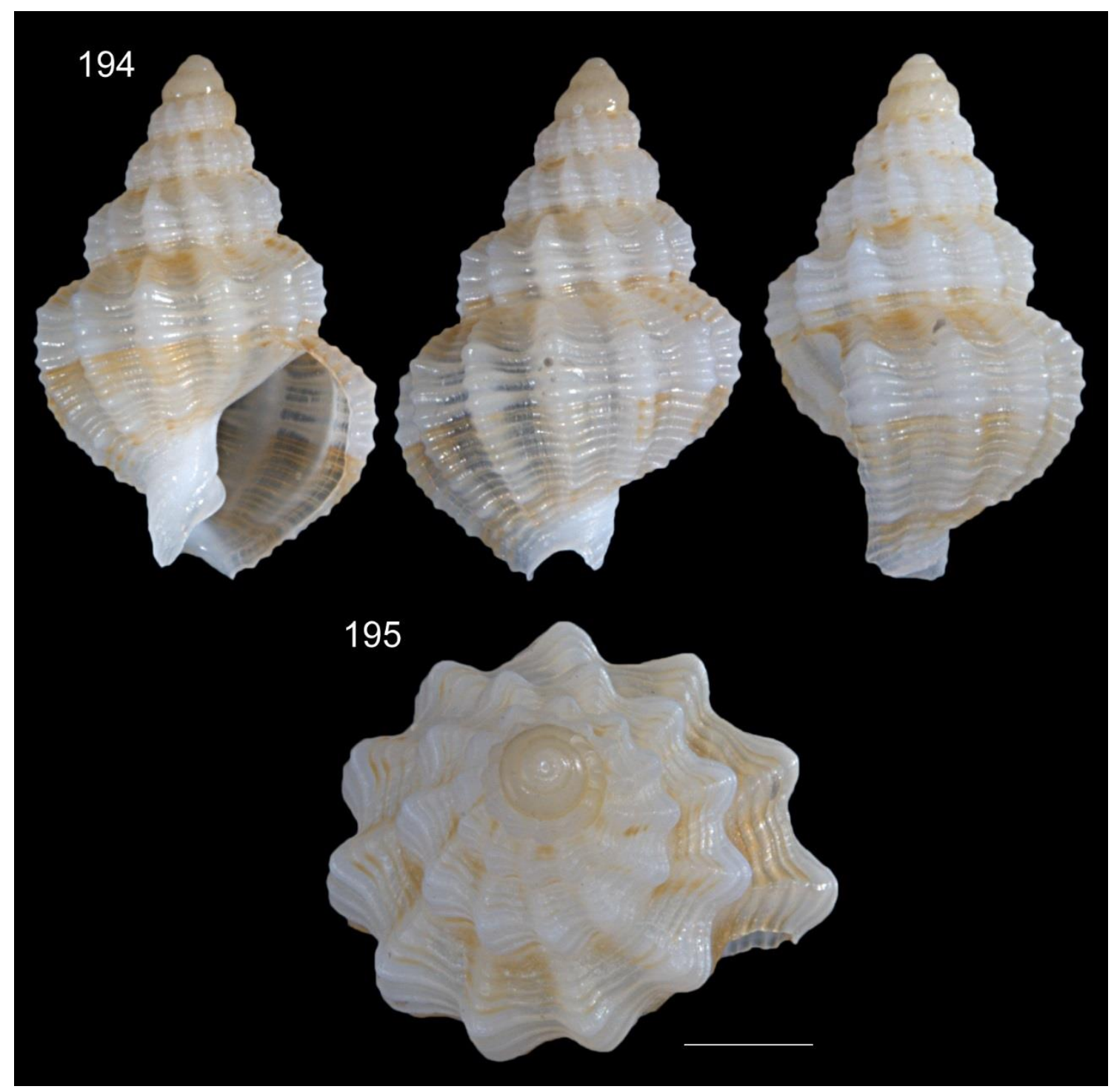

Figs. 194-195. Nassarius paucicostatus: MZSP 92843, shell; Fig. 194: Adult specimen, Shell, apertural, dorsal and lateral views (L 6.6); Fig. 195: same, apical view, Scale $=1 \mathrm{~mm}$. 


\section{Nassarius vibex (Say, 1822)}

Figs. 196-214.

Vide Cernorhorsky, 1984: Page: 41; complement:

Shell (Figs. 196, 197). Ovate, about twice long as wide, with 6 convex whorls; color light to dark gray. Protoconch small, smooth, amber, with about two and a half whorls; transition to teleoconch hardly indicated by a depression and by the difference of sculpturing. Teleoconch sculpture composed of light gray axial ribs along entire surface and dark gray spiral nodules near the sutures, spire angle $\sim 50^{\circ}$, shoulder absent. Aperture prosocline, rounded, posteriorly acuminate, ca. 1/2 of shell length; color white with black spots; outer lip thick, palatal wall smooth; parietal rib medially present; Parietal shield strongly developed, covering about $1 / 2$ of ventral surface of body whorl; Anal notch weakly marked. Siphonal canal short, strong, deep, narrow ( 1/2 of aperture length) and dorsally recurved.

Head-foot (Figs. 200, 202, 203). Pallial cavity covering 1/2 of total animal length; muscular siphon located on left, length $\sim 1 / 3$ of head-foot length. Head protruded; tentacles separated from each other, elongated and narrow, $3 \mathrm{x}$ as long as head; eyes pedunculated, located in medium region of tentacles. Foot long, occupying about of entire length of body whorl (retracted), flat, bearing a pair of medium metapodial tentacles; pedal gland located in middle region of foot (Fig.), forming a groove, extending to dorsum of foot (propodium). Opercular pad occupying $~ 1 / 8$ of dorsal area of foot, oval. Penis originated in right lateral region, posterior to cephalic base, at level of mantle edge. Columellar muscle small and broad, 1/2 whorl long. Haemocoel long and broad, extending dorsally along center of foot and columellar muscle, $2 \mathrm{x}$ as long as wide (Fig.).

Operculum (Fig. 198). Medium size, ovate, horny, dark orange to amber; occupying almost entire aperture. Nucleus terminal, inferior. Outer surface with normal concentric growth lines, forming undulations. Scar elliptical, occupying about $2 / 3$ of inner surface, located close to edge of foot.

Mantle organs (Figs.204, 205, 207). Mantle cavity covering 1 whorl. Siphon width $1 / 3$ of mantle cavity width, length $1 / 2$ of mantle cavity length. Right base of siphon high, width about three times as mantle edge width; left base low ending gradually. Osphradium long and wide, elliptical, length $\sim 90 \%$ of pallial cavity length, width $\sim 1 / 4$ of its width. Osphradial filaments short, broad. Ctenidial vein (efferent branchial vessel) uniformly narrow along its length. Gill long and wide, occupying 95\% of length and 1/3 of width of pallial cavity. Anterior end of gill rounded, ending in a well marked fold. Gill 
filaments uniformly narrow along its length. Posterior end of gill tapered, located in posterior region of mantle cavity, inserted into pericardium. Gill filaments low and rounded. Hypobranchial gland strong glandular. Right side of pallial cavity almost entirely filled by gonoducts. Rectum short and thick, occupying $\sim 2 / 3$ of pallial cavity width. Anus siphoned, distance between anus and mantle border 1/2 of total pallial cavity length. Anal gland absent.

Visceral mass (Fig. 205). About 2 1/2 whorls posterior to mantle cavity. Digestive gland dark beige, occupying $~ 80 \%$ of visceral mass, encircling stomach. Gonad orange with small black spots, located on columellar surface, posterior to stomach. Seminal vesicle of males located in anterior portion of gonad, $~ 1 / 2$ of its size. Kidney occupying $\sim 2 / 3$ of visceral mass volume, located on right side of anterior visceral end. Stomach small, located half whorl in front of pallial cavity.

Circulatory and excretory systems (Figs. 204, 205, 207). Reno-pericardial region occupying 1 whorl, adjacent to mantle cavity; square shaped. Pericardium occupying 1/6 of reno-pericardial region, posterior to gill; situated on left anterior margin of visceral mass. Auricle membranous, anterior to ventricle; with three connections: on upper right side with kidney, on anterior right side with gill, and on posterior left side with ventricle. Ventricle three times as large as auricle, with common aorta in left posterior margin. Aorta thin, located along postero-left region of ventricle, anterior aorta with twice diameter of posterior aorta. Kidney occupying $1 / 4$ of pallial cavity length, renal lobe single, solid; efferent renal vessel located at its right portion. Nephridial gland not seen in detail. Nephrostome small, longitudinal slit, located in anterior region of membrane between kidney and pallial cavity.

Digestive system (Figs. 201, 206, 208-211). Mouth longitudinal, narrow. Proboscis straight, long and broad, occupying about $90 \%$ of haemocoel volume. Rhynchodeal wall thick and membranous, involving $2 / 3$ of proboscis. Thin retractor muscles covering almost entire length of proboscis. Salivary glands located at anterior portion of haemocoel, occupying 1/6 of haemocoel volume, entirely involving nerve ring, middle esophagus and anterior portion of proboscis. Salivary ducts very narrow, running completely attached to anterior esophagus wall and, more anteriorly, inside dorsal wall of buccal cavity; opening large, closed to the mouth. Valve of Leiblein medium, about $1 / 8$ of proboscis volume, located in medium esophagus anterior to nervous ring, diameter about 1/3x of the medium esophagus, anterior region with transverse white band bearing long cilia, middle and posterior regions white, corresponding to inner gland 
that occupies most of inner surface. Gland of Leiblein narrow and elongated, 2x longer than middle esophagus, becoming gradually narrower towards posterior, duct of Gland of Leiblein, short and broad. Accessory salivary glands absent. Anterior esophagus thin uniformly narrow along its length; walls muscular, with one internal longitudinal folds, occupying entire length of proboscis. Middle esophagus with the same diameter of anterior esophagus; posterior esophagus $\sim 90 \%$ of total haemocoel lenght, thin, with constant diameter along its entire length, differentiation between middle and posterior esophagus not clear. Stomach simple, ovate with several internal folds with same size, digestive gland ducts not analyzed in detail.

Odontophore and buccal mass muscles: $m j$, thick of perioral muscles connected on both sides, dorsal and ventral, surrounding odontophore cartilages; $m 1$, jugal muscles, several tinny and thin fibers which connected odontophore in proboscis wall; $m 2$, pair of strong protractor muscles of buccal mass, originating on inner surface of proboscis, running along entire odontophore, inserting in anterior region of odontophore cartilages; $m 2 a$, pair of retractor muscles of buccal mass, originating on dorsal surface of haemocoel, inserting at end of posterior margin of odontophore cartilages; $m 2 b$, two pairs of thin retractors muscles, auxiliary of $\mathrm{M} 2 \mathrm{t} ; \mathrm{m} 3$, long and cylindrical muscle forming outer wall of odontophore, with transverse fibers; $m 4$, pairs of strong radular dorsal tensor muscles covering almost entire surface of posterior portion of odontophore cartilages, originating outside edges of cartilage and inserting into subradular membrane; $m 5$, pair of auxiliary dorsal tensor muscles of radula, originating inside edges of cartilage, adjacent to $\mathrm{m} 4$ insertion; $m 6$, horizontal muscle, thick, connecting ventral edges of cartilages, running $\sim 2 / 3$ of their length; $m 8$, pair of elliptical small muscles, $\sim 1 / 8$ of total length of odontophore, originating at anterior end of odontophore cartilages, running along ventral surface of odontophore, inserting on anterior ventral surface of cartilages; $m 11$, pair of ventral tensor muscles of radula, about $1 / 3$ of total odontophore length, originating at ventral-posterior end of cartilages, crossing ventrally entire odontophore, inserting into ventral posterior surface of radula. Additional odontophore structures: $b r$, subradular membrane, thin, strong and translucent, along entire length of radular ribbon, covering inner surface of odontophore cartilages; oc, odontophore cartilages, about $3 \mathrm{x}$ long as wide, inner ventral surface concave, $\sim 1 / 3$ of anterior end fused with each other; $r s$, radular sac thin-walled, cylindrical, located at posterior end of radula; $n r$, radular nucleus width $\sim 1 / 2$ of radular sac width. 
Radular teeth (Fig. 199). Rachidian tooth wide, comb-like, occupying about half of radular width; base curved, width $\sim 3 \times$ its length; $\sim 14$ triangular, sharp pointed cusps of similar size, except for some diminishment towards the side; lateral tooth hook-like, with two cusps, base broad (equivalent to rachidian base width), obliquely disposed; main lateral cusp widely curved inwards, about as long as base; secondary cusp approximately half size of main lateral cusp; radula ribbon equal between males and females; jaws absent.

Genital system. Male (Fig. 212). Vas deferens narrow, simple, straight, running along ventral surface of kidney up to pallial cavity. Prostate totally closed (tubular), running thought right mantle edge, at $\sim 1 / 3$ of total pallial cavity length. Vas deferens anterior to prostate, straight, running immersed into integument of dorsum, next to mantle border and penis base. Penis slender, length $\sim 2 / 4$ of total head-foot length, dorso-ventrally flattened and with wide point at anterior half; base curved, anterior region with half of posterior region diameter, apical region thin with a terminal papilla in leaf form. Penial duct straight, running through center of penis, closed (tubular). Penial aperture distal, small.

Female (Figs. 204. 205, 214). Visceral oviduct narrow, straight, running along dorsal surface of kidney in first whorl of visceral mass, located in front of pallial cavity. Posterior region of pallial oviduct protruding into kidney, occupying $~ 2 / 3$ of length of pallial cavity and $1 / 5$ of its width. Albumen gland posterior, whitish, thin-walled, occupying $\sim 1 / 3$ of pallial oviduct. Capsule gland $\sim 2 / 3$ of oviduct, elongated, orange, thick-walled, female genital pore narrow located at dorsal surface of bursa copulatrix. Bursa copulatrix rounded, membranous, occupying about 1/5 of oviduct length. Cement gland located closed to the sole foot, rounded, forming a groove (Fig.).

Central nervous system (Fig. 213). Nerve ring located in ventral anterior proboscis region, occupying $\sim 1 / 12$ of haemocoel volume, highly concentrated. Ganglia mostly fused, hard to distinguish from each other, somewhat asymmetrical. Pairs of pleural and cerebral ganglia fully fused with each other. Sub-esophageal ganglia large about $1 / 4$ of nerve ring volume with two strong's commissure. One pair of buccal ganglia located at ventral surface of cerebral ganglia, almost on its size. Esophageal aperture small, central, located in middle region of pleural and cerebral ganglia. Pair of Statocysts located at ventral surface of pleural ganglia, formed by a sand grain enveloped by mucus. 
Shell measurements (length $x$ width in $\mathrm{mm}$ ): $5 \hat{0} 18.2 \times 10.4 ; 17.9 \times 10 ; 18.4 \mathrm{x}$ $11.3 ; 18.4$ x $10.9 ; 15.7$ x 9.3; 4 ㅇ 19.6 x 12.4; 18.9 x $13.1 ; 18.6$ x $12.7 ; 19.5$ x 12.6.

Distribution: Massachusetts, West cost of U.S.A., Caribbean Sea to Santa Catarina, Brazil.

Habitat: Fine sand bottoms, infratidal.

Material examined: MZSP 46821: 20, 1q, U.S.A.: Florida: Ft. Pierce, $27^{\circ} 28^{\prime} \mathrm{N}$ $80^{\circ} 18^{\prime} \mathrm{W}$, (Simone col., 07/viii/2004); MZSP 34241: 1ð^, 1ㅇ, Brazil: Rio Grande do Norte, Porto do Mangue $05^{\circ} 03^{\circ} \mathrm{S} 36^{\circ} 46^{\prime} \mathrm{W}$, (Simone col. Iv/2001); MZSP 38347: 2 ๙, 2 , Caraguatatuba, Est. 83i (pegador Van Veen 19m, 16/x2001). 


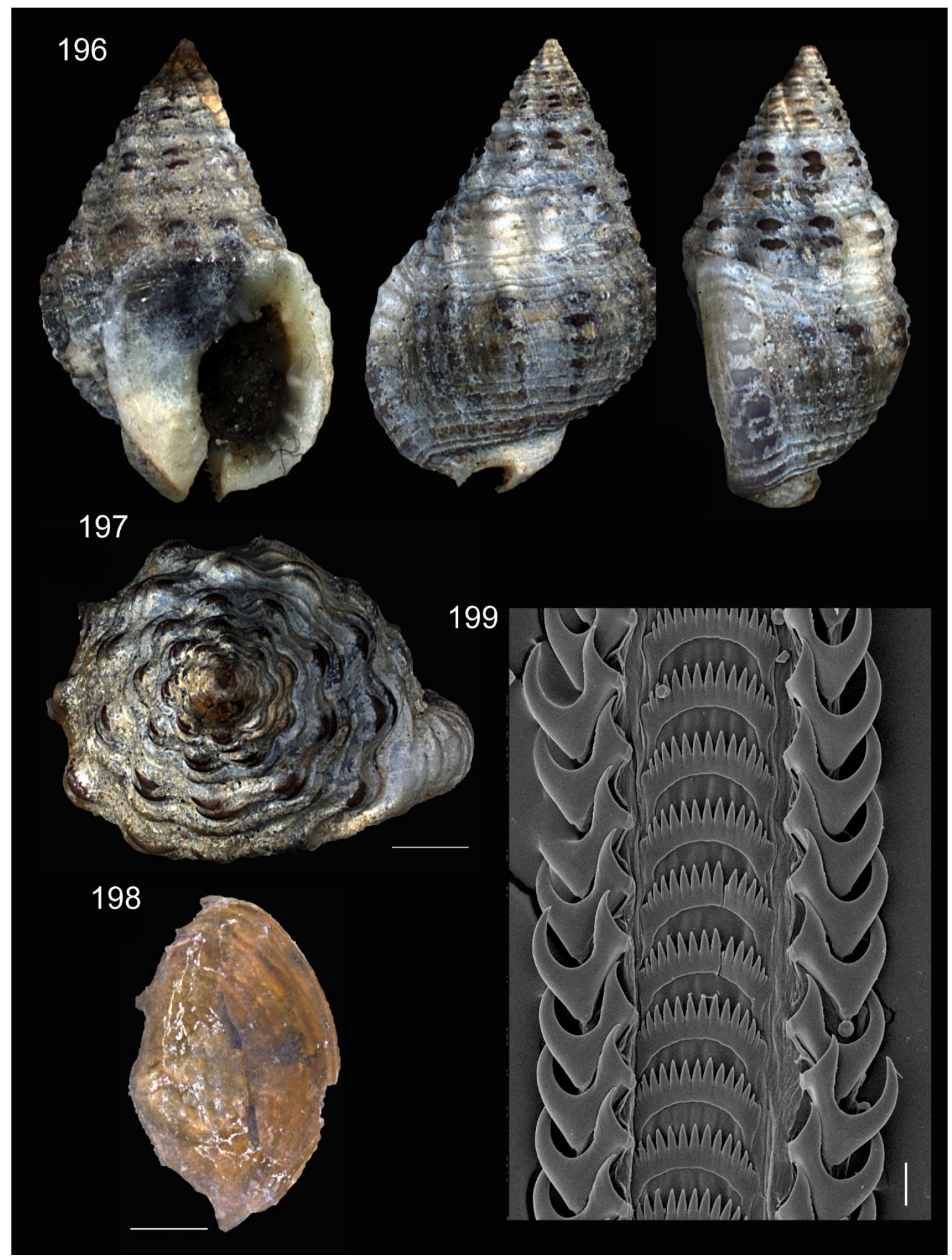

Figs. 196-199. Nassarius vibex: MZSP 46821 q, shell, operculum and radula; Fig. 196: Adult specimen, Shell apertural, dorsal and lateral views (L 15,6 mm); Fig. 197: Adult specimen, shell apical view, scale= 2mm; Fig. 198: Operculum dorsal view, scale = $1 \mathrm{~mm}$; Fig. 199; SEM of radula: Panoramic view of middle portion, scale $=30 \mu \mathrm{m}$. 

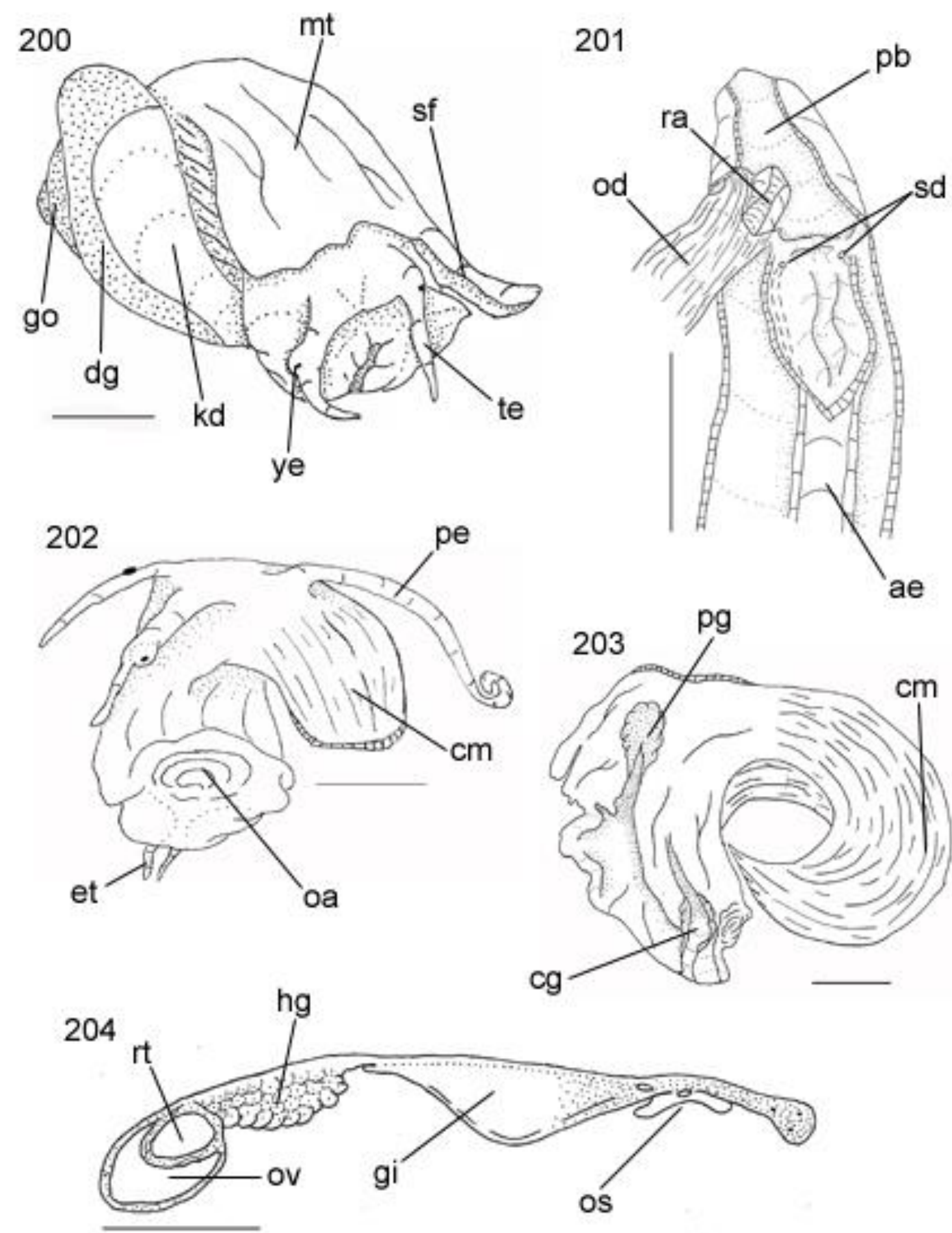

Figs. 200-204. Nassarius vibex: details of anatomy. Fig. 200: complete specimen extracted from shell (operculum removed), anterior-right view; Fig. 201: Proboscis and anterior esophagus opened longitudinally, showing salivary ducts and their apertures; Fig. 202: Male left lateral view, detail of penis and epipodiais tentacles; Fig. 203: Foot of female, sagittal section; Fig. 204: Pallial cavity roof, transverse section at middle level of osphradium. Scales $=2 \mathrm{~mm}$. 


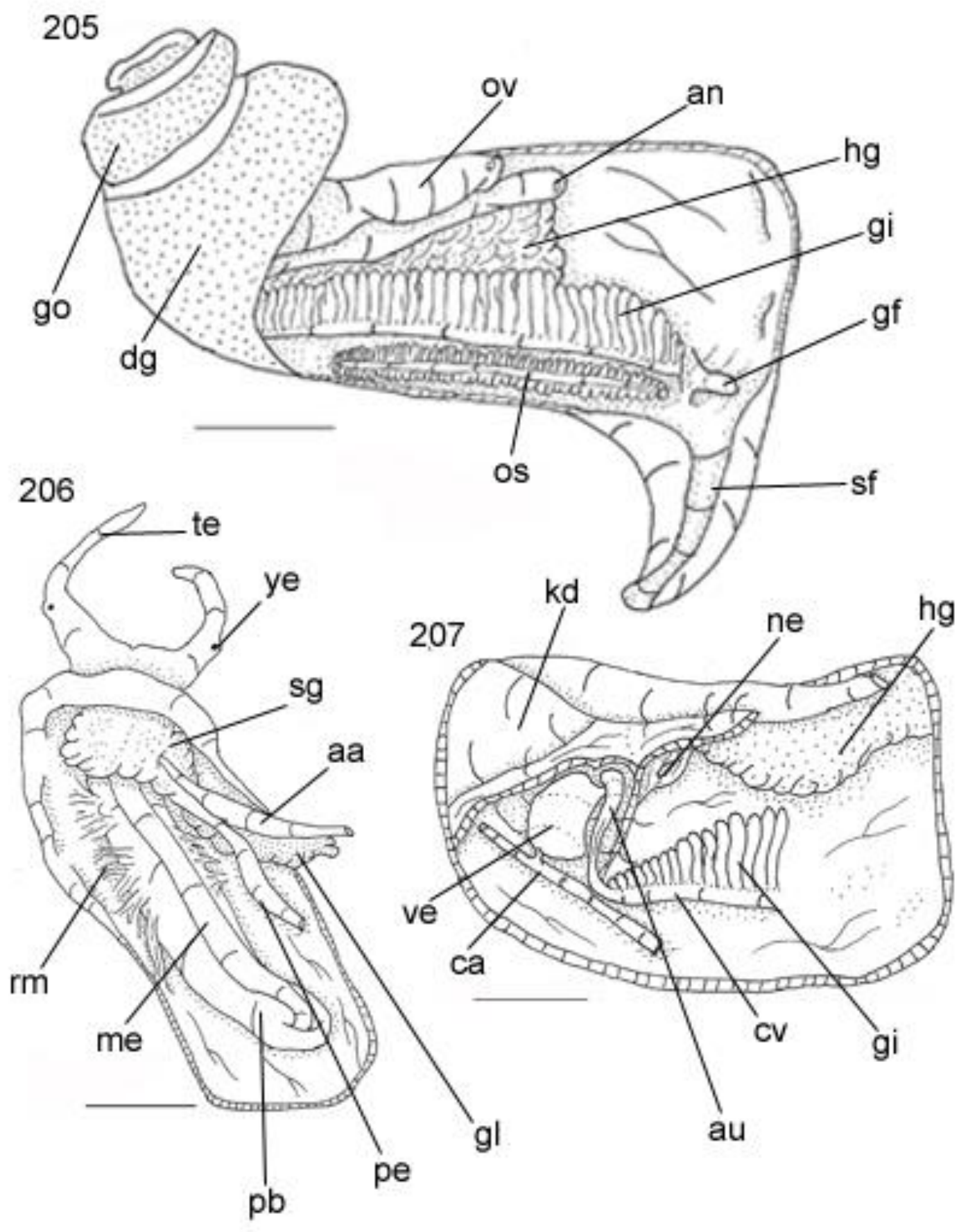

Figs. 205-207. Nassarius vibex: Fig. 205: Pallial cavity roof, ventral view; Fig. 206: Head and haemocoel, ventral view, foot and columellar muscle removed; Fig. 207: Detail of circulatory and excretory system. Scales $=2 \mathrm{~mm}$. 

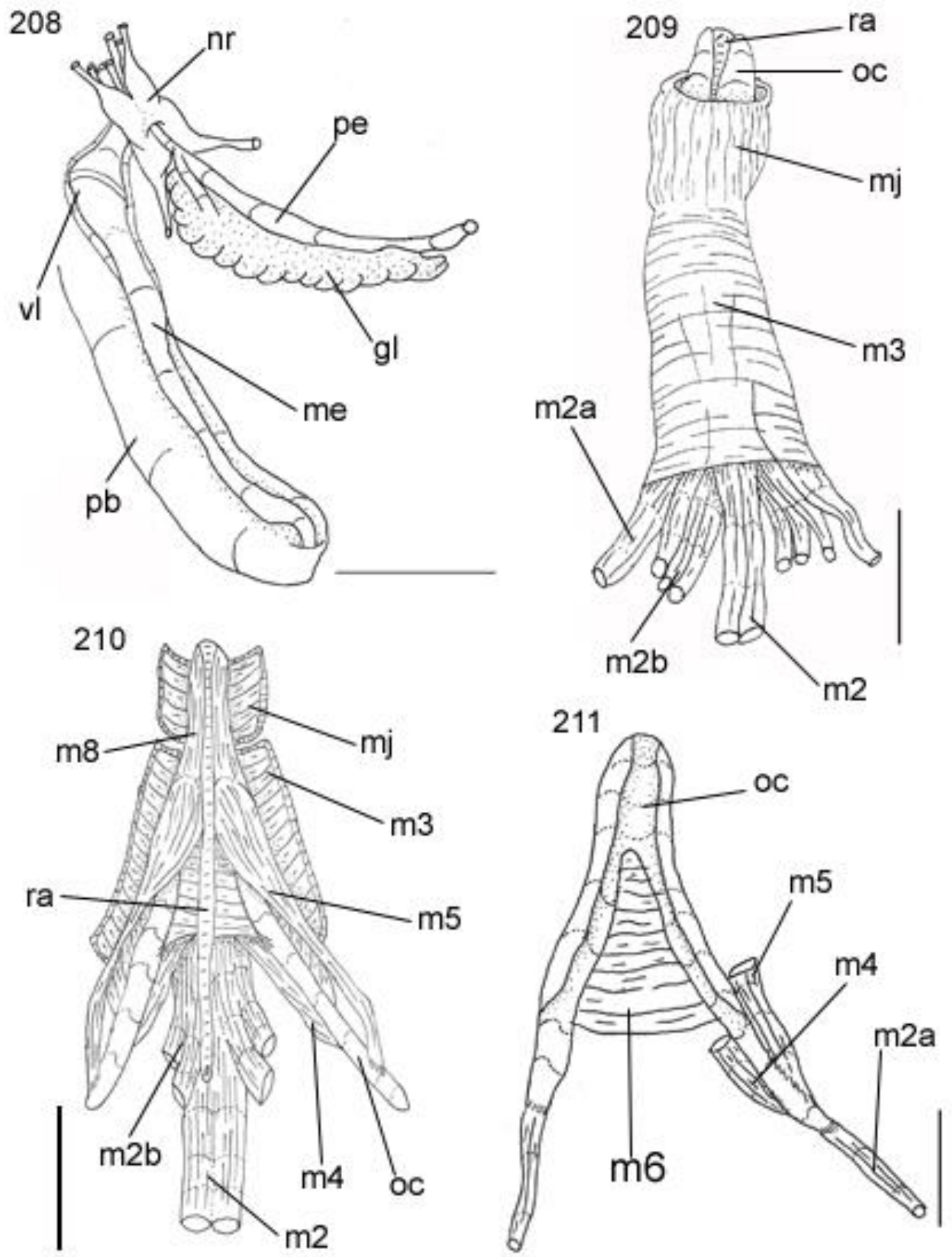

Figs. 208-211. Nassarius vibex: Fig. 208: Detail of fore and midgut, associated structures also shown; Fig. 209: Odontophore, dorsal view, superficial layers showed; Fig: 210: Odontophore, dorsal view, superficial muscles dissected; Fig. 211: Odontophore cartilages, associated muscles shown. Scales = $2 \mathrm{~mm}$. 

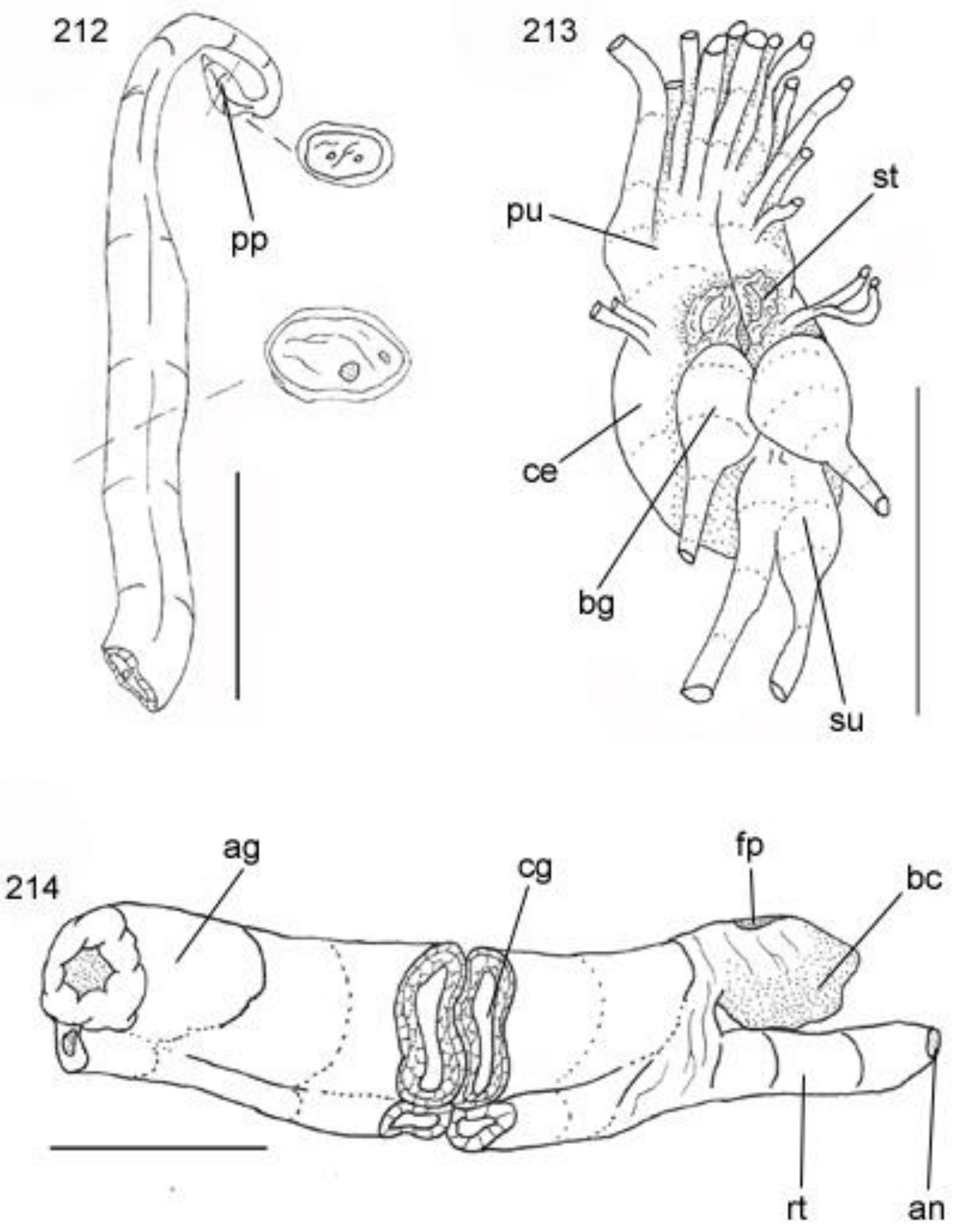

Figs. 212-214. Nassarius vibex: Fig. 212: Penis, lateral left view; Fig. 213: Nerve ring, dorsal view; Fig. 214: Pallial oviduct, right lateral view. Scales $=2 \mathrm{~mm}$. 


\section{Nassarius coronatus (Bruguière, 1789)}

Vide Cernohorsky, 1984: 58 (pl 1. Figs. 10, 11).

Figs. 215-225.

Shell (Figs. 215, 216). Ovate, about twice long as wide, with $\sim 5$ convex whorls; color light brown. Protoconch small, smooth, light beige, with about 2 1/2 whorls; transition to teleoconch hardly indicated by a depression and by the difference of sculpturing. Teleoconch sculpture composed of light gray axial ribs along entire surface and dark gray spiral nodules near the sutures, spire angle $\sim 70^{\circ}$, shoulder absent. Aperture prosocline, rounded, posteriorly acuminate, ca. 1/2 of shell length; color white; outer lip thick, palatal wall lirate, parietal rib weakly present; Parietal shield weakly developed, covering only the inner lip; Anal notch well marked. Siphonal canal very short, strong, deep, narrow ( 1/3 of aperture length) and dorsally recurved.

Head-foot (Figs. 218, 221). Pallial cavity with $\sim 1$ 1/2 whorl; muscular siphon located on left, long, about same length of head-foot length. Head protruded; tentacles closed from each other, elongated and narrow, $3 \mathrm{x}$ as long as head; eyes pedunculated, located in medium region of tentacles. Foot big, occupying almost entire body whorl (retracted), flat, bearing a pair of medium metapodial tentacles; pedal gland located in anterior medium region of foot, forming a small groove, extending to dorsum of foot (propodium). Opercular pad occupying 1/7 of dorsal area of foot, oval. Penis originated in right lateral region, posterior to cephalic base, at level of mantle edge. Columellar muscle small and broad, 1 whorl long. Haemocoel short, extending dorsally along center of foot and columellar muscle, $1.5 \mathrm{x}$ as long as wide.

Operculum (Fig.). Not visualized. None of the analyzed specimens carried an operculum.

Mantle organs (Figs. 222). Siphon width $1 / 3$ of mantle cavity width, long, length $1 / 2$ of mantle cavity length. Right base of siphon low, width about two times as mantle edge width; left base low ending gradually. Osphradium long and thin, elliptical, length $1 / 4$ of pallial cavity length, width $\sim 1 / 5$ of its width. Osphradial filaments short, broad. Ctenidial vein (efferent branchial vessel) uniformly narrow along its length. Gill long and wide, occupying $\sim 2 / 3$ of length and $\sim 1 / 4$ of width of pallial cavity. Anterior end of gill rounded, ending gradually, inserted directly into pallial cavity. Gill filaments increasing in size in middle region. Posterior end of gill tapered, located in posterior region of mantle cavity, inserted into pericardium. Right side of pallial cavity almost entirely filled by gonoducts. Rectum long and thin, occupying $~ 2 / 3$ of pallial cavity width. Anus simple, 
distance between anus and mantle border 1/5 of total pallial cavity length. Anal gland absent. Circulatory and excretory systems (Fig.). Reno-pericardial region like anterior specimens. Pericardium occupying $1 / 4$ of reno-pericardial region, posterior to gill; situated on left anterior margin of visceral mass. Auricle small, membranous, anterior to ventricle. Ventricle four times as large as auricle, with common aorta in left posterior margin. Aorta thin, located along postero-left region of ventricle, anterior aorta with twice diameter of posterior aorta. Kidney occupying $1 / 2$ of pallial cavity length, renal lobe single, divided into chambers; efferent renal vessel located at its right portion. Nephrostome small, transversal slit, located in anterior region of membrane between kidney and pallial cavity.

Digestive system (Figs. 219, 220, 223). Mouth longitudinal, narrow. Proboscis long and thick, occupying all most of haemocoel length. Rhynchodeal wall thick and muscular. Thin retractor muscles covering half of proboscis length. Salivary glands same as previous species. Salivary ducts very narrow, running completely attached to anterior esophagus wall and, more anteriorly, inside dorsal wall of buccal cavity along the folds. Valve of Leiblein small, about 1/6 of salivary gland volume, located in medium esophagus anterior to nervous ring, anterior region with transverse white band bearing long cilia, middle and posterior regions white, corresponding to inner gland occupying most of inner surface; bypass absent. Gland of Leiblein slender, very narrow, $\sim 2 \mathrm{x}$ as long as middle esophagus, becoming gradually narrower posteriorly; duct of gland of Leiblein lon and narrow. Anterior esophagus thin, uniformly narrow along its length; walls muscular, occupying entire length of proboscis. Middle esophagus with the same diameter of anterior esophagus; posterior esophagus $\sim 90 \%$ of total haemocoel lenght, thin, with constant diameter along its entire length, differentiation between middle and posterior esophagus not clear.

Odontophore and buccal mass muscles: $m j$, thick of perioral muscles connected on both sides, dorsal and ventral, surrounding odontophore cartilages small, tapered, 1/6 of odontophore length; $m 1$, same as previous species; $m 2$, Strong protractor muscles of buccal mass, originating on inner surface of proboscis, running along entire odontophore, inserting in anterior region of odontophore cartilages; $m 2 a$, pair of retractor muscles of buccal mass, originating on dorsal surface of haemocoel, inserting at end of posterior margin of odontophore cartilages; $m 2 b$, absent; $m 2 c$, absent; $m 3$, like previous species; $m 4$, pairs of strong radular dorsal tensor muscles covering almost entire surface of posterior portion of odontophore cartilages, originating outside edges of cartilage and 
inserting into subradular membrane; $m 5$, pair of auxiliary dorsal tensor muscles of radula, originating inside edges of cartilage, adjacent to $\mathrm{m} 4$ insertion; $m 6$, horizontal muscle, thick, connecting ventral edges of cartilages, running $\sim 2 / 3$ of their length; $m 8$, pair of elliptical muscles, $\sim 1 / 4$ of total length of odontophore, originating at anterior end of odontophore cartilages, running along ventral surface of odontophore, inserting on anterior ventral surface of cartilages. Additional odontophore structures similar to all nassarids.

Radular teeth (Fig. 217). Rachidian tooth wide, comb-like, occupying about half of radular width; base curved, width $\sim 3 \times$ its length; $\sim 11$ triangular, sharp pointed cusps of similar size, except for some diminishment towards the side; lateral tooth hook-like, with two cusps of same size, base broad (equivalent to rachidian base width), obliquely disposed; radula ribbon equal between males and females.

Genital system. Male (Fig. 224). Vas deferens and prostate similar to previous nassarids. Penis slender, length $\sim 2 / 3$ of total head-foot length, dorso-ventrally flattened, anterior end bulged. Penial duct straight, running through center of penis, closed (tubular). Penial aperture distal, small, without papilla.

Female (Figs. 222). Visceral oviduct narrow, straight, running along dorsal surface of kidney in first whorl of visceral mass, located in front of pallial cavity. Posterior region of pallial oviduct protruding into kidney, occupying $\sim 1 / 2$ of length of pallial cavity and 1/5 of its width. Albumen gland posterior, whitish, thin-walled, occupying $~ 1 / 3$ of pallial oviduct. Capsule gland $\sim 2 / 3$ of oviduct, elongated, orange, thick-walled, female genital pore slit, small. Bursa copulatrix absent. Cement gland absent.

Central nervous system (Fig.225). Nerve ring located in ventral anterior proboscis region, occupying $\sim 1 / 12$ of haemocoel volume, highly concentrated, pedal commissure visible, somewhat asymmetrical. Pairs of pleural and cerebral ganglia fully fused with each other. Sub-esophageal ganglia located in middle region of cerebropleural ganglia. Esophageal aperture small, central, located in middle region of pedal and cerebral ganglia, occupying about $1 / 6$ of surface of nerve ring. 
Shell measurements (length $x$ width in $\mathrm{mm}$ ): MZSP 69217; 1 + 16.1 x 9.8; 1 ð 14.2 x 8.7 .

Distribution: Red Sea, Gulf of Oman to South Africa; Japan; Solomon Island.

Habitat: Fine and sand bottoms, to $46 \mathrm{~m}$.

Material examined: MZSP 69217; 1ㅇ, 10ิ Japan, West Okynawa, Malibu Beach (J. Coltro, v/2006). 


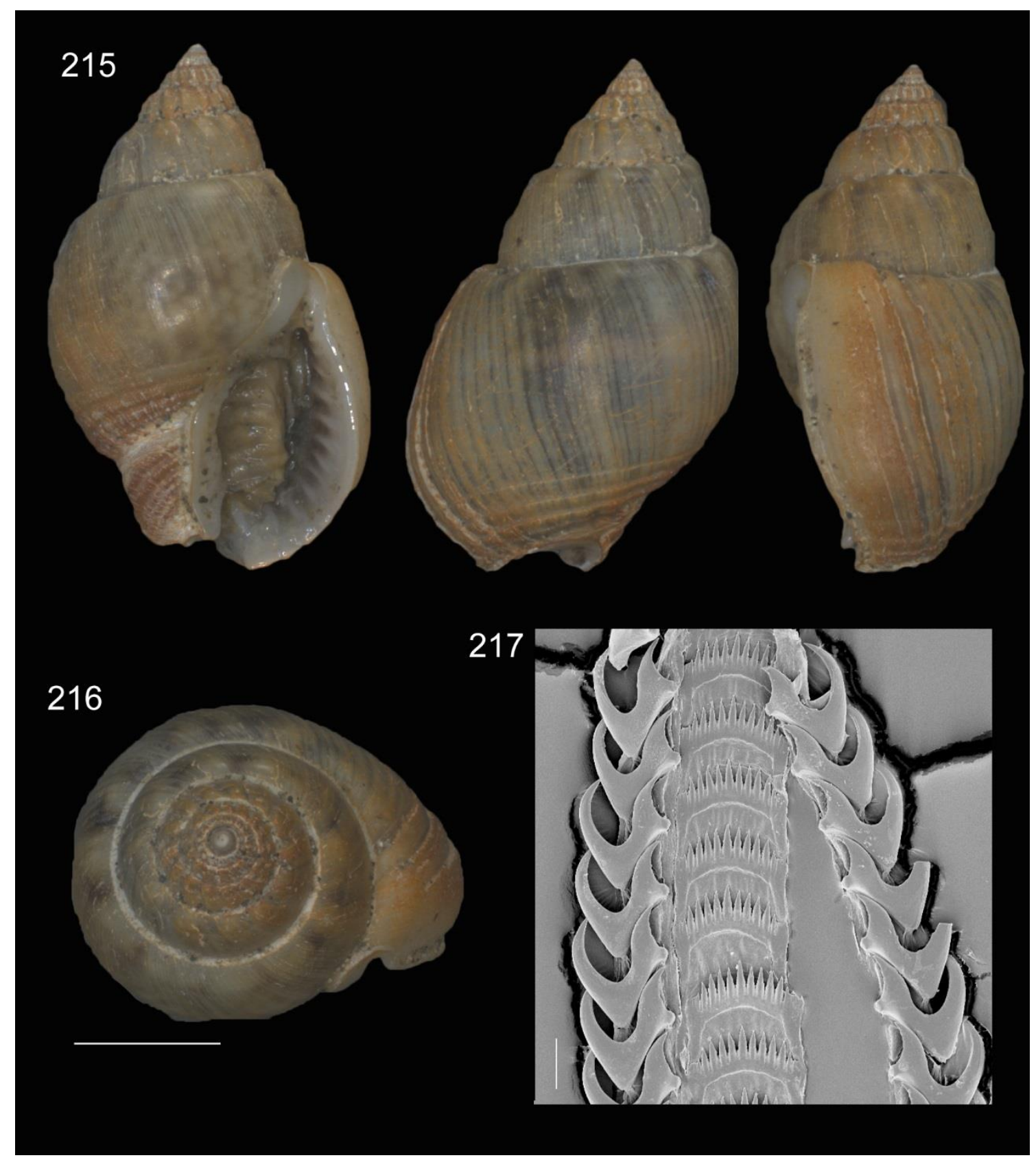

Figs 215-217. Nassarius coronatus: MZSP 69217 ㅇ, shell and radula; Figs 215: Adult specimen, Shell apertural, dorsal and lateral view (L 16,7 mm); Fig. 216: shell apical view, scale $=2 \mathrm{~mm}$; Fig. 217; SEM of radula: Panoramic view of middle portion, scale $=30 \mu \mathrm{m}$. 

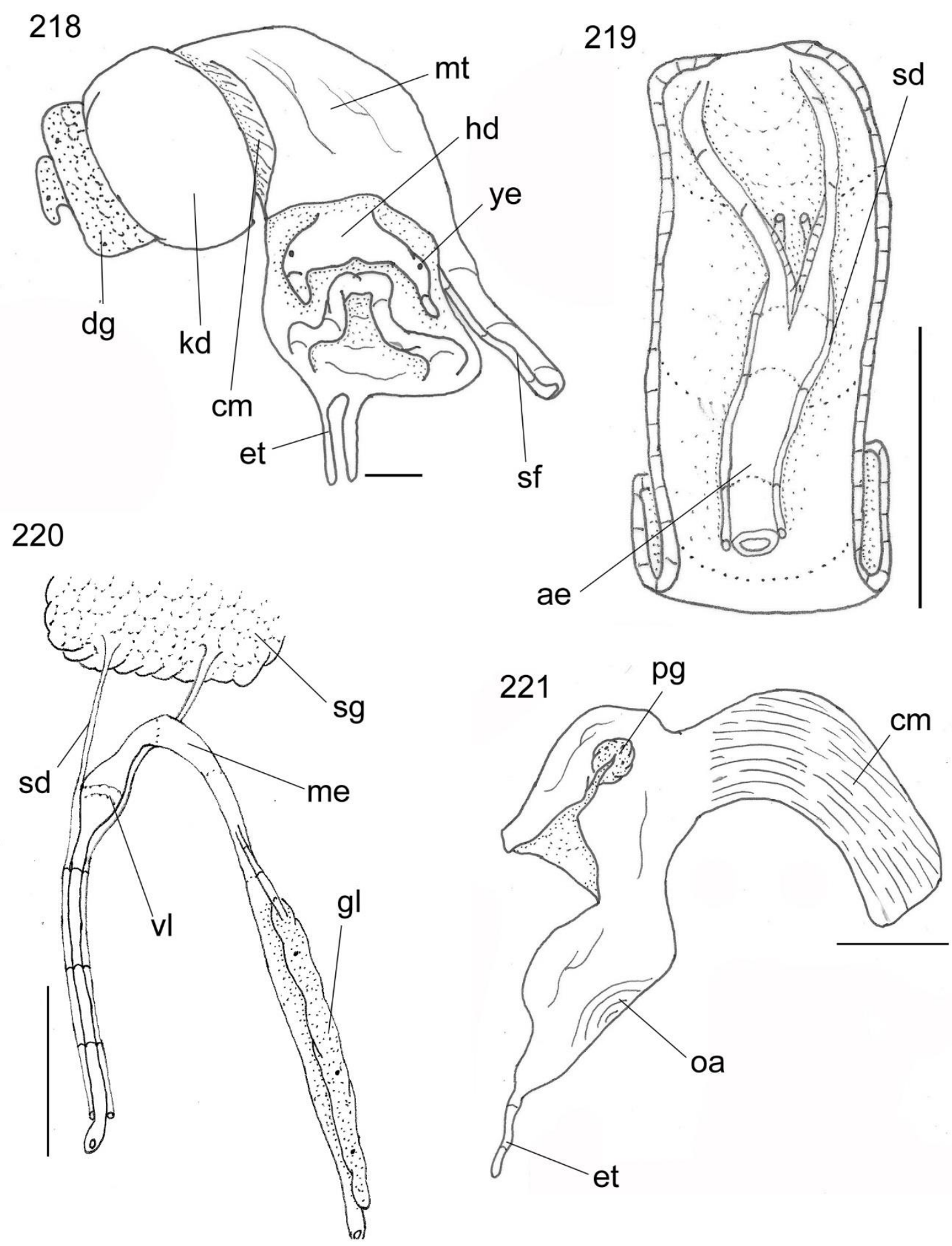

Figs 218-221. Nassarius coronatus: Details of anatomy, Fig. 218: complete specimen extracted from shell (operculum removed), anterior-right view; Fig. 219: Proboscis and anterior esophagus opened longitudinally, showing salivary ducts and their apertures; Fig. 220: Detail of Circulatory and excretory systems; Fig. 221: Foot of female, sagittal section, Scales $=2 \mathrm{~mm}$. 


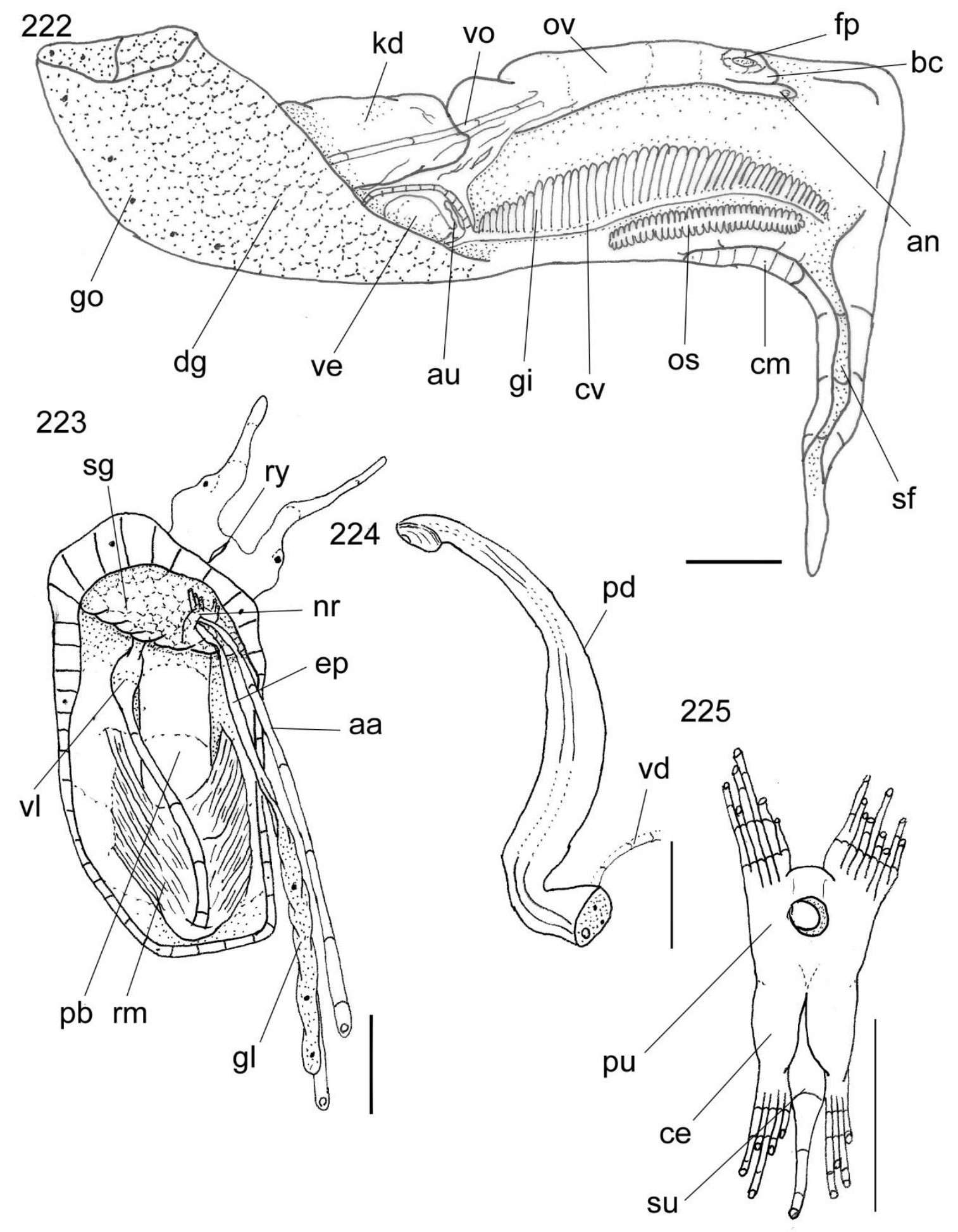

Figs 222-225. Nassarius coronatus: Details of anatomy, Fig. 222: Pallial cavity roof, ventral view; Fig. 223: Head and haemocoel, ventral view, foot and columellar muscle removed; Fig. 224: Penis, lateral left view; Fig. 225: Nerve ring, dorsal view. Scales $=2 \mathrm{~mm}$. 


\section{Tribe Phrontini tribe nov.}

\section{Genus Phrontis H. Adams \& A. Adams, 1853}

Type species: Buccinum tiarula Kiener, 1841 by subsequent designition.

Phrontis incrassata (Stroem, 1768) comb. Nov.

Vide Cernorhorsky, 1984: Page: 50. Complement:

Nassarius incrassatus Cernohorsky, 1984.

Tritia incrassata Marshall, 2016.

Figs. 226-237.

Shell (Figs. 226, 227). Ovate, about twice long as wide, with 6 convex whorls; color beige to light cream, with brown and gray bands in the anterior region of whorls, near sutures. Protoconch small, smooth, cream, with about two whorls; transition to teleoconch hardly indicated by a depression and by the difference of sculpturing. Teleoconch sculpture composed of cream axial ribs along entire surface and brown and gray spiral nodules near the sutures, spire angle $\sim 55^{\circ}$, shoulder absent. Aperture prosocline, rounded, posteriorly acuminate, ca. 1/2 of shell length; color white; outer lip thick, palatal wall smooth; parietal rib strongly present; Parietal shield absent; Anal notch well marked. Siphonal canal short, strong, deep, narrow ( 1/2 of aperture length) and dorsally recurved.

Head-foot (Figs. 229, 231). Pallial cavity covering 1/2 of total animal length; muscular siphon located on left, length $\sim 1 / 2$ of head-foot length. Head protruded; tentacles separated from each other, elongated and narrow, 3x as long as head; eyes pedunculated, located in medium region of tentacles. Foot small, occupying half of body whorl (retracted), flat, bearing a pair of medium metapodial tentacles; pedal gland located in anterior edge of foot, forming a groove, extending to dorsum of foot (propodium). Opercular pad occupying 1/8 of dorsal area of foot, oval. Columellar muscle small and broad, 1/2 whorl long. Haemocoel short and broad, extending dorsally along center of foot and columellar muscle, $2 \mathrm{x}$ as long as wide.

Operculum (Fig. 228). Medium size, ovate, horny, amber; occupying almost entire aperture. Nucleus terminal, inferior. Outer surface with normal concentric growth lines, forming undulations. Scar elliptical, occupying about $2 / 3$ of inner surface, located close to edge of foot; expansions in the form of spines absent.

Mantle organs (Figs. 232). Mantle cavity covering $~ 1$ whorl. Siphon width 1/4 of mantle cavity width, length $1 / 2$ of mantle cavity length. Right base of siphon high, width about three times as mantle edge width; left base low ending gradually. Osphradium long 
and thin, elliptical, length $2 / 3$ of pallial cavity length, width $\sim 1 / 5$ of its width. Osphradial filaments short, broad. Ctenidial vein (efferent branchial vessel) uniformly narrow along its length. Gill long, occupying half of length and 1/4 of width of pallial cavity. Anterior end of gill rounded, ending gradually, inserted directly into pallial cavity. Gill filaments increasing in size in middle region. Posterior end of gill tapered, located in posterior region of mantle cavity, inserted into pericardium. Gill filaments low and rounded. Right side of pallial cavity almost entirely filled by gonoducts. Rectum long and thin, occupying $\sim 2 / 3$ of pallial cavity width. Anus pedunculated, distance between anus and mantle border $1 / 5$ of total pallial cavity length. Anal gland absent.

Visceral mass (Figs. 232). Similar to previous species.

Circulatory and excretory systems (Fig. 232). Reno-pericardial region occupying 1 whorl, adjacent to mantle cavity; square shaped. Pericardium occupying 1/4 of renopericardial region, posterior to gill; situated on left anterior margin of visceral mass. Auricle triangular membranous, anterior to ventricle; with three connections: on upper right side with kidney, on anterior right side with gill, and on posterior left side with ventricle. Ventricle four times as large as auricle, with common aorta in left posterior margin. Aorta thin, located along postero-left region of ventricle, anterior aorta with twice diameter of posterior aorta. Kidney occupying $1 / 4$ of pallial cavity length, renal lobe single, solid; efferent renal vessel located at its right portion. Nephridial gland not seen in detail. Nephrostome small, transversal slit, located in anterior region of membrane between kidney and pallial cavity.

Digestive system (Figs. 230, 233, 235-237). Mouth longitudinal, narrow. Proboscis short and broad, occupying about $90 \%$ of haemocoel lenght. Rhynchodeal wall thick and membranous, involving $2 / 3$ of proboscis. Thick retractor muscles covering posterior end of proboscis. Salivary glands located at anterior portion of haemocoel, occupying $~ 1 / 5$ of haemocoel volume, entirely involving nerve ring, middle esophagus and anterior portion of proboscis. Salivary ducts very narrow, running completely attached to anterior esophagus wall and, more anteriorly, inside dorsal wall of buccal cavity along the folds; opening very small, closed to the mouth. Valve of Leiblein medium, about 1/8 of proboscis volume, located in medium esophagus anterior to nervous ring, diameter about $1 / 5 \mathrm{x}$ of the medium esophagus, anterior region with transverse white band bearing long cilia, middle and posterior regions white, corresponding to inner gland that occupies most of inner surface. Gland of Leiblein broad and elongated, 2x longer than middle esophagus, becoming gradually narrower towards posterior, duct of Gland of 
Leiblein, long and narrow. Accessory salivary glands absent. Foregut same as $N$. arcularia.

Odontophore and buccal mass muscles: $m j$, absent,; $m 1$, jugal muscles, several tinny and thin fibers which connected odontophore in proboscis wall; $m 2$, two pair of strong protractor muscles of buccal mass, originating on inner surface of proboscis, running along entire odontophore, inserting in anterior region of odontophore cartilages; $m 2 a$, pair of retractor muscles of buccal mass, originating on dorsal surface of haemocoel, inserting at end of posterior margin of odontophore cartilages; $m 2 b$, absent; $m 2 c$, absent; $m 3$, long and cylindrical muscle forming outer wall of odontophore, with transverse fibers; $m 4$, pairs of strong radular dorsal tensor muscles covering almost entire surface of posterior portion of odontophore cartilages, originating outside edges of cartilage and inserting into subradular membrane; $m 5$, pair of auxiliary dorsal tensor muscles of radula, originating inside edges of cartilage, adjacent to $\mathrm{m} 4$ insertion; $m 6$, horizontal muscle, thick, connecting ventral edges of cartilages, running $95 \%$ of their length; $m 8$, pair of elliptical muscles, $\sim 1 / 4$ of total length of odontophore, originating at anterior end of odontophore cartilages, running along ventral surface of odontophore, inserting on anterior ventral surface of cartilages; $m 11$, pair of ventral tensor muscles of radula, about $1 / 3$ of total odontophore length, originating at ventral-posterior end of cartilages, crossing ventrally entire odontophore, inserting into ventral posterior surface of radula. Additional odontophore structures: $b r$, subradular membrane, thin, strong and translucent, along entire length of radular ribbon, covering inner surface of odontophore cartilages; $o c$, odontophore cartilages, about $3 x$ long as wide, inner ventral surface concave, $\sim 1 / 4$ of anterior end fused with each other; $r s$, radular sac thin-walled, cylindrical, located at posterior end of radula; $n r$, radular nucleus width $\sim 1 / 2$ of radular sac width.

Radular teeth. Not visualized

Genital system. Male. Not analized

Female (Figs. 232). Visceral oviduct narrow, sinuous, running along dorsal surface of kidney in first whorl of visceral mass, located in front of pallial cavity. Posterior region of pallial oviduct protruding into kidney, occupying $\sim 2 / 3$ of length of pallial cavity and 1/5 of its width. Albumen gland posterior, whitish, thin-walled, occupying $~ 1 / 3$ of pallial oviduct. Capsule gland $\sim 2 / 3$ of oviduct, elongated, orange, thick-walled. Vaginal atrium thin, tubular, occupying $~ 1 / 8$ of oviduct; walls thick, muscular, female genital pore slot shaped. Bursa copulatrix absent. Cement gland absent. 
Central nervous system (Fig. 234). Nerve ring located in ventral anterior proboscis region, occupying $~ 1 / 12$ of haemocoel volume, highly concentrated. Ganglia mostly fused, hard to distinguish from each other, somewhat asymmetrical. Pairs of pleural and cerebral ganglia fully fused with each other. Buccal ganglia dorsal, large $\sim 1 / 2$ of pedal ganglia. Sub-esophageal not seen in detail. Esophageal aperture wide, central, located in midlle region of pleural and cerebral ganglia, occupying about 1/6 of surface of nerve ring. Statocysts not visualyzed.

Shell measurements (length $x$ width in $\mathrm{mm}$ ): MZSP 92103; 2 + 12.3 x 6.5; $11.9 \mathrm{x}$ 6.2 .

Distribution: Mediterranean Sea; North Atlantic.

Habitat: Fine and sand bottoms.

Material examined: MZSP 92103; 2 \%, Portugal, Aveiro; Ria de Aveiro (Low Tide, J. Jardim, 2009). 


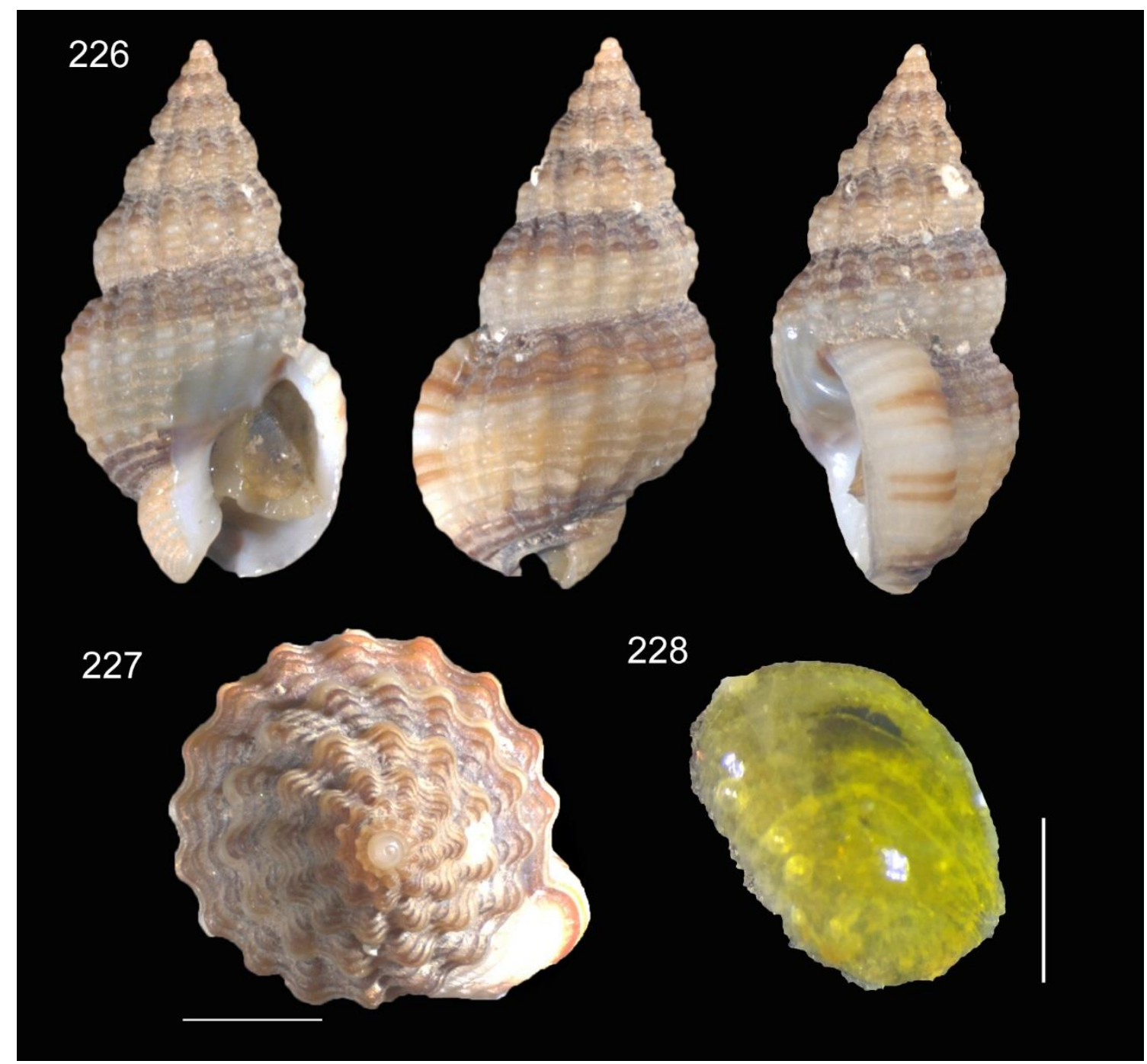

Figs. 226-228. Phrontis Incrassata: MZSP 92103 , shell, operculum and radula; Fig. 226: Adult specimen, Shell apertural, dorsal and lateral view; (L 12,3 mm); Fig. 227: shell apical view, scale $=2 \mathrm{~mm}$; Fig. 228: Operculum dorsal view, scale $=2 \mathrm{~mm}$. 

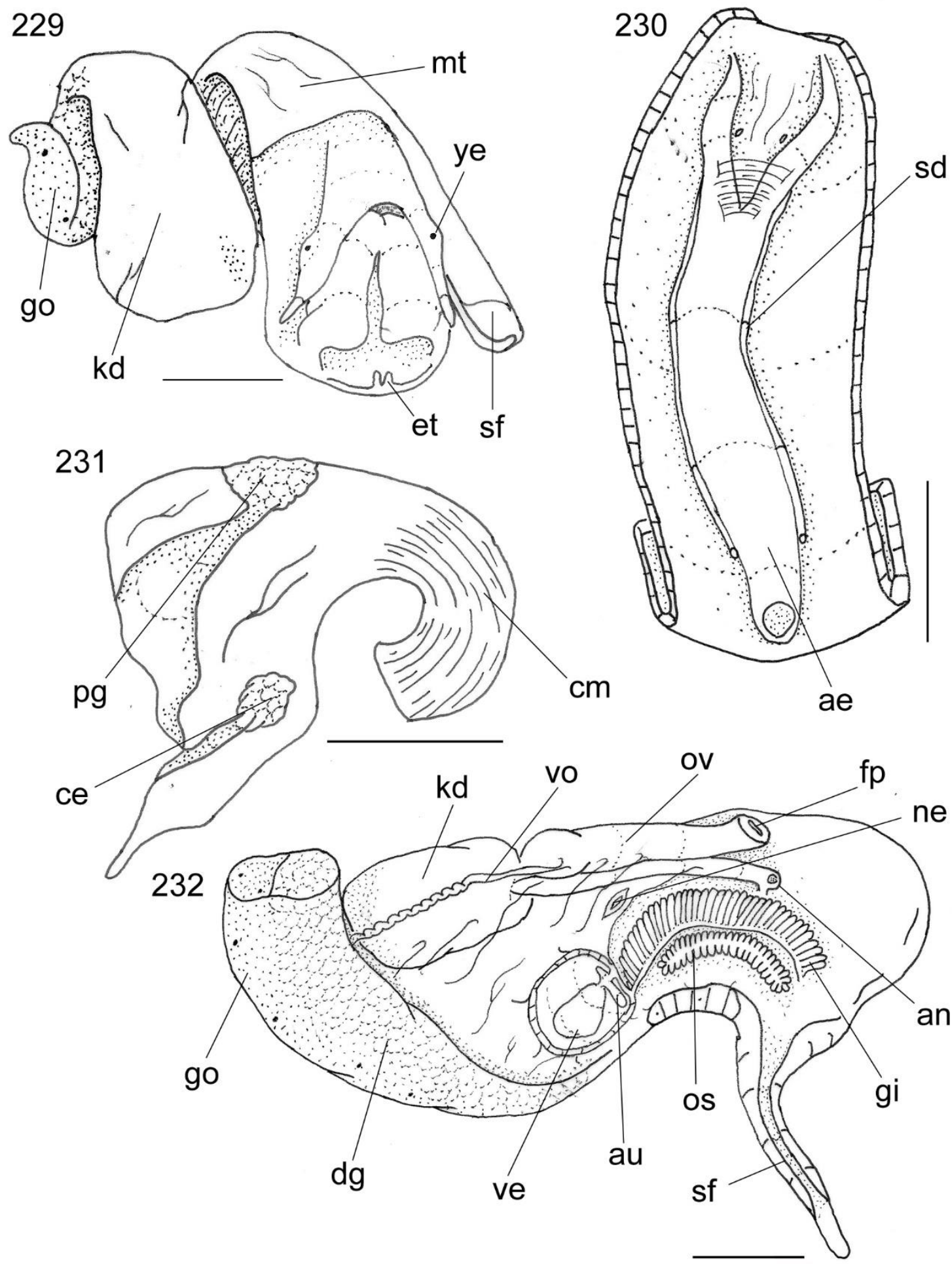

Figs. 229-232. Phrontis Incrassata: Details of anatomy, Fig. 229: complete specimen extracted from shell (operculum removed), anterior-right view; Fig. 230: Proboscis and anterior esophagus opened longitudinally, showing salivary ducts and their apertures; Fig. 231: Foot of female, sagittal section; Fig. 232: Pallial cavity roof, ventral view. Scales $=2 \mathrm{~mm}$. 

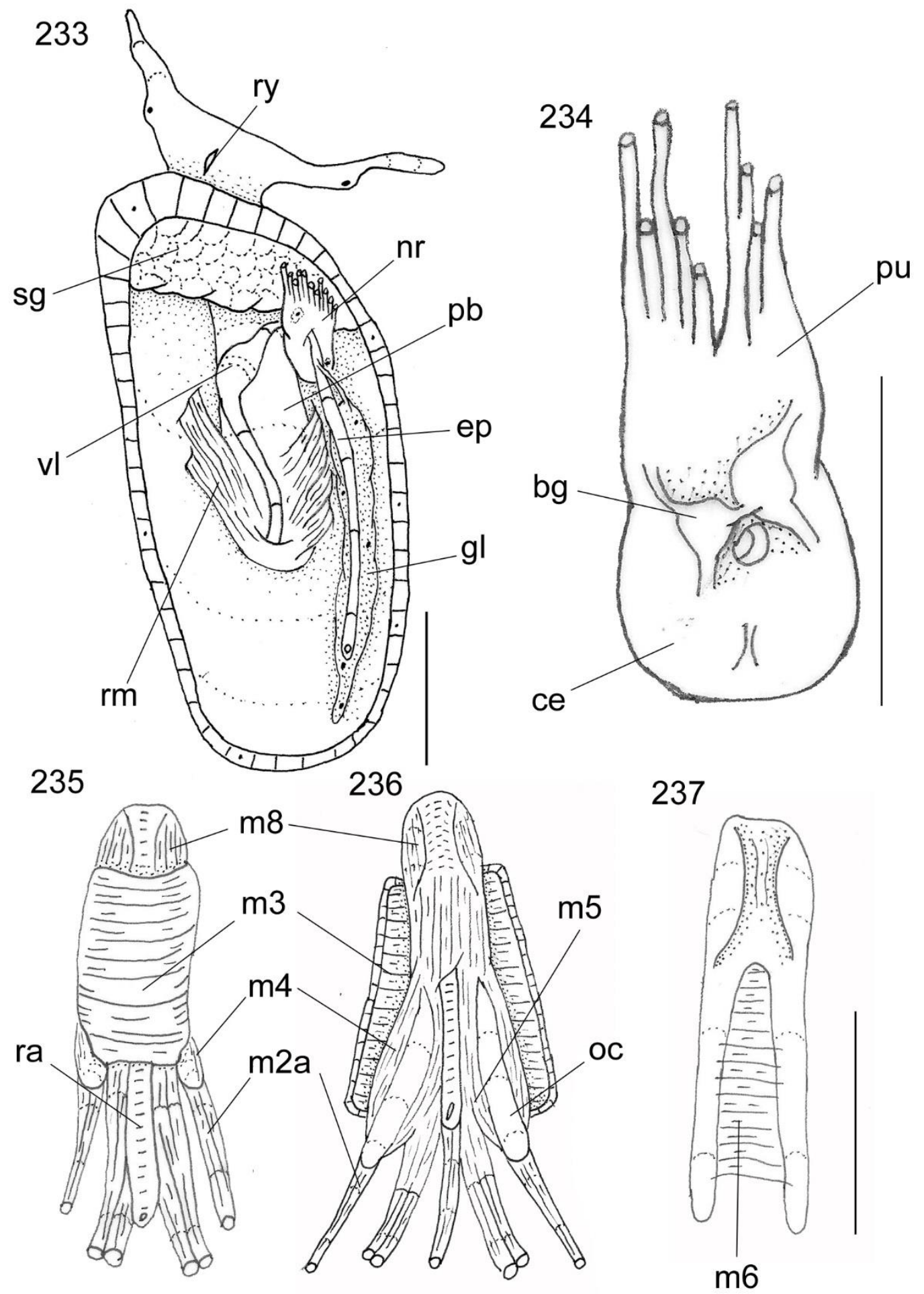

Figs. 233-237. Phrontis Incrassata: Details of anatomy, Fig. 233: Head and haemocoel, ventral view, foot and columellar muscle removed; Fig. 234: Nerve ring, dorsal view; Fig. 235: Odontophore, dorsal view, superficial layers showed; Fig. 236: Odontophore, dorsal view, superficial muscles dissected; Fig. 237: Odontophore cartilages. Scales $=2 \mathrm{~mm}$. 


\section{Phrontis alba (Say, 1826) comb. nov.}

Figs. 238-253.

Buccinum ambiguum Pulteney, 1799: 42.

Nassa acuta Say, 1826: 5 (fig. 234).

Nassa alba Say, 1826: 5 (fig. 212).

Nassa candei d'Orbigny, 1843: 142 (pl. 23).

Nassa clathratula A. Adams, 1852: 99.

Nassa obtusata A. Adams, 1852: 100.

Nassa annelifera Reeve, 1853: 8 (pl. 25).

Nassa pura Marrat, 1877: 13

Nassa quinquecostata Marrat, 1880: 61.

Nassarius albus Say, 1826; Abbott, 1974.

Shell (Figs. 238, 239). Ovate, about twice long as wide, with 5 convex whorls; color, light brown, brown and white, with cream and brown bands in the middle region of whorls. Protoconch smooth, cream, with two whorls; transition to teleoconch hardly indicated by a depression and by the difference of sculpturing. Teleoconch sculpture composed of light brown and white axial ribs along entire surface and white spiral nodules near the sutures, spire angle $\sim 60^{\circ}$, shoulder absent. Aperture prosocline, rounded, posteriorly acuminate, $\sim 1 / 2$ of shell length; color white; outer lip thick, palatal wall lirated; parietal rib strongly present. Parietal shield limited to internal lip; Anal notch weakly marked. Siphonal canal short, strong, deep, narrow ( 1/3 of aperture length) and dorsally recurved.

Head-foot (Figs. 242. 246). Pallial cavity covering $1 / 2$ of total animal length; muscular siphon long located on left, length $\sim 1 / 2$ of head-foot length. Head not protruded; tentacles closed from each other, elongated and narrow; eyes pedunculated, located in medium region of tentacles. Foot small, occupying half of body whorl (retracted), flat, bearing a pair of medium metapodial tentacles; pedal gland located in anterior edge of foot, forming a groove, extending to dorsum of foot (propodium). Opercular pad occupying $~ 1 / 8$ of dorsal area of foot, oval. Penis originated in right lateral region, posterior to cephalic base, at level of mantle edge. Columellar muscle small and broad, $1 / 2$ whorl long. Haemocoel short and broad, extending dorsally along center of foot and columellar muscle, $2 \mathrm{x}$ as long as wide.

Operculum (Fig. 240). Small, ovate, horny, yellow, semi-translucent; occupying about $70 \%$ of aperture. Nucleus terminal, inferior. Outer surface with normal concentric 
growth lines, forming undulations. Scar elliptical, occupying about $2 / 3$ of inner surface, located close to edge of foot; expansions in the form of spines absent.

Mantle organs (Figs. 244, 248). Mantle cavity covering $\sim 1$ whorl. Siphon large, width $1 / 2$ of mantle cavity width, length $2 / 3$ of mantle cavity length. Right base of siphon high, width about three times as mantle edge width; left base low. Osphradium long and thin, elliptical, length $1 / 3$ of pallial cavity length, width $\sim 1 / 6$ of its width. Osphradial filaments short, broad. Ctenidial vein (efferent branchial vessel) uniformly narrow along its length. Gill medium and wide, occupying $~ 1 / 2$ of length and 1/3 of width of pallial cavity. Anterior end of gill rounded, ending gradually, inserted directly into pallial cavity. Gill elliptical. Anterior end of gill tapered. Gill filaments high and triangular. Right side of pallial cavity almost entirely filled by gonoducts. Rectum long and thin, occupying $\sim 2 / 3$ of pallial cavity width. Anus pedunculated, distance between anus and mantle border $1 / 3$ of total pallial cavity length. Anal gland absent.

Visceral mass (Fig. 244). About 2 1/2 whorls posterior to mantle cavity. Digestive gland dark beige, occupying $~ 80 \%$ of visceral mass, encircling stomach. Gonad orange with small black spots, located on columellar surface, posterior to stomach. Seminal vesicle of males located in anterior portion of gonad, $\sim 1 / 2$ of its size. Kidney occupying $\sim 1 / 2$ of visceral mass volume, located on right side of anterior visceral end. Stomach small, located half whorl in front of pallial cavity.

Circulatory and excretory systems (Fig. 244, 248). Reno-pericardial region occupying 1 whorl, adjacent to mantle cavity; square shaped. Pericardium occupying 1/4 of reno-pericardial region, posterior to gill; situated on left anterior margin of visceral mass. Auricle triangular membranous, auricular connections not seen in details. Ventricle four times as large as auricle, with common aorta in left posterior margin. Aorta thin, located along postero-left region of ventricle. Kidney occupying 1/3 of pallial cavity length, renal lobe single, solid; efferent renal vessel located at its right portion. Nephrostome small, transversal slit, located in anterior region of membrane between kidney and pallial cavity.

Digestive system (Figs. 243, 245, 249-251). Mouth longitudinal, narrow. Proboscis long and broad, occupying about $90 \%$ of haemocoel volume. Rhynchodeal wall thick, involving $2 / 3$ of proboscis. Thin retractor muscles covering posterior end of proboscis. Salivary glands located at anterior portion of haemocoel, occupying $\sim 1 / 5$ of haemocoel volume, entirely involving nerve ring, middle esophagus and anterior portion of proboscis. Salivary ducts very narrow, running completely attached to anterior 
esophagus wall and, more anteriorly, inside dorsal wall of buccal cavity along the folds ; opening very small, located in the anterior region of oral tube. Valve of Leiblein small, about $1 / 8$ of proboscis volume, located in medium esophagus anterior to nervous ring, diameter about $1 \mathrm{x}$ of the medium esophagus, anterior region with transverse white band bearing long cilia, middle and posterior regions white, corresponding to inner gland that occupies most of inner surface. Gland of Leiblein narrow and short, 2x longer than middle esophagus, uniformly narrow along its length, duct of Gland of Leiblein, very long and narrow. Accessory salivary glands absent. Anterior esophagus thin uniformly narrow along its length; walls muscular, folds, occupying entire length of proboscis. Middle esophagus with the same diameter of anterior esophagus; posterior esophagus $\sim 90 \%$ of total haemocoel lenght, thin, with constant diameter along its entire length, differentiation between middle and posterior esophagus not clear.

Odontophore and buccal mass muscles: $m j$, thick of perioral muscles connected on both sides, dorsal and ventral, surrounding odontophore cartilages short, about 1/6 of odontophore length,; $m 1$, jugal muscles, several tinny and thin fibers which connected odontophore in proboscis wall; $m 2$, Pair of strong protractor muscles of buccal mass, originating on inner surface of proboscis, running along entire odontophore, inserting in anterior region of odontophore cartilages; $m 2 a$, absent; $m 2 b$, absent; $m 2 c$, tinny transversal muscle auxiliary of $\mathrm{m} 2 ; m 3$, long and cylindrical muscle forming outer wall of odontophore, with longitudinal fibers; $m 4$, pairs of thin, strong radular dorsal tensor muscles covering almost entire surface of posterior portion of odontophore cartilages, originating outside edges of cartilage and inserting into subradular membrane; $m 5$, pair of thin auxiliary dorsal tensor muscles of radula, originating inside edges of cartilage, adjacent to $\mathrm{m} 4$ insertion; $m 6$, horizontal muscle, thin, connecting ventral edges of cartilages, running $\sim 2 / 3$ of their length; $m 8$, pair of elliptical muscles, $\sim 1 / 4$ of total length of odontophore, originating at anterior end of odontophore cartilages, running along ventral surface of odontophore, inserting on anterior ventral surface of cartilages; $m 11$, pair of ventral tensor muscles of radula, about $1 / 3$ of total odontophore length, originating at ventral-posterior end of cartilages, crossing ventrally entire odontophore, inserting into ventral posterior surface of radula. Additional odontophore structures: $b r$, subradular membrane, thin, strong and translucent, along entire length of radular ribbon, covering inner surface of odontophore cartilages; $o c$, odontophore cartilages, square shaped, about $2 \mathrm{x}$ long as wide, inner ventral surface concave, $\sim 1 / 4$ of anterior end fused with each other. 
Radular teeth (Fig. 241). Rachidian tooth wide, comb-like, occupying about half of radular width; base curved, length $\sim 3 \times$ its width; $\sim 12$ triangular, sharp pointed cusps of similar size, except for some diminishment towards the side; lateral tooth hook-like, with two cusps, base broad (equivalent to rachidian base width), obliquely disposed; main lateral cusp widely curved inwards, about as long as base; secondary cusp approximately $1 / 2$ size of main lateral cusp with 1 secondary small cusp; radula ribbon equal between males and females.

Genital system. Male (Fig. 253). Vas deferens narrow, simple, sinuous, running along ventral surface of kidney up to pallial cavity. Prostate totally closed (tubular), running thought right mantle edge, at $\sim 1 / 3$ of total pallial cavity length. Vas deferens anterior to prostate, straight, running immersed into integument of dorsum, next to mantle border and penis base. Penis slender, length $\sim 2 / 4$ of total head-foot length, dorso-ventrally flattened and with wide point at anterior half; base curved, apical region tapered. Penial duct straight, running through center of penis, closed (tubular). Penial aperture distal, small.

Female (Figs. 244, 247, 248). Visceral oviduct thin, narrow, sinuous, running along dorsal surface of kidney in first whorl of visceral mass, located in front of pallial cavity. Pallial oviduct small, protruding into kidney, occupying $\sim 1 / 3$ of length of pallial cavity and $1 / 5$ of its width. Albumen gland posterior, whitish, thick-walled, occupying $\sim 1 / 5$ of pallial oviduct. Capsule gland $\sim 4 / 5$ of oviduct, elongated, orange, thick-walled. Vaginal atrium wide, tubular, occupying $~ 1 / 5$ of oviduct; walls thick, muscular, female genital pore wide. Bursa copulatrix absent. Cement gland absent.

Central nervous system (Fig. 252). Nerve ring located in ventral anterior proboscis region, occupying 1/12 of haemocoel volume, highly concentrated. Ganglia mostly fused, hard to distinguish from each other, somewhat symmetrical. Pairs of pleural and cerebral ganglia fully fused with each other. One pair of buccal ganglia located at ventral surface of cerebral ganglia, small, $\sim 1 / 2$ of its size. Sub-esophageal ganglion about the same size of cerebral ganglion. Esophageal aperture small, central, located in midlle region of pleural and cerebral ganglia, occupying about 1/6 of surface of nerve ring. Pair of statocysts located at ventral surface of cerebral ganglia. 
Shell measurements (length $x$ width in $\mathrm{mm}$ ): UF 4445077; $2 \bigcirc^{\Uparrow} 10.1 \mathrm{x} 6.6 ; 10.2 \mathrm{x}$ $6.8 ; 1 q 11.2 \times 6.9$.

Distribution: Florida, Caribean.

Habitat: fine and sand bottoms, intertidal.

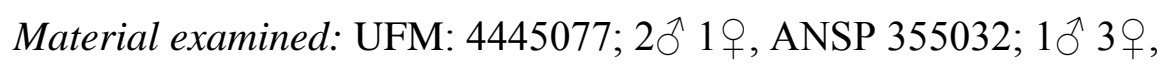




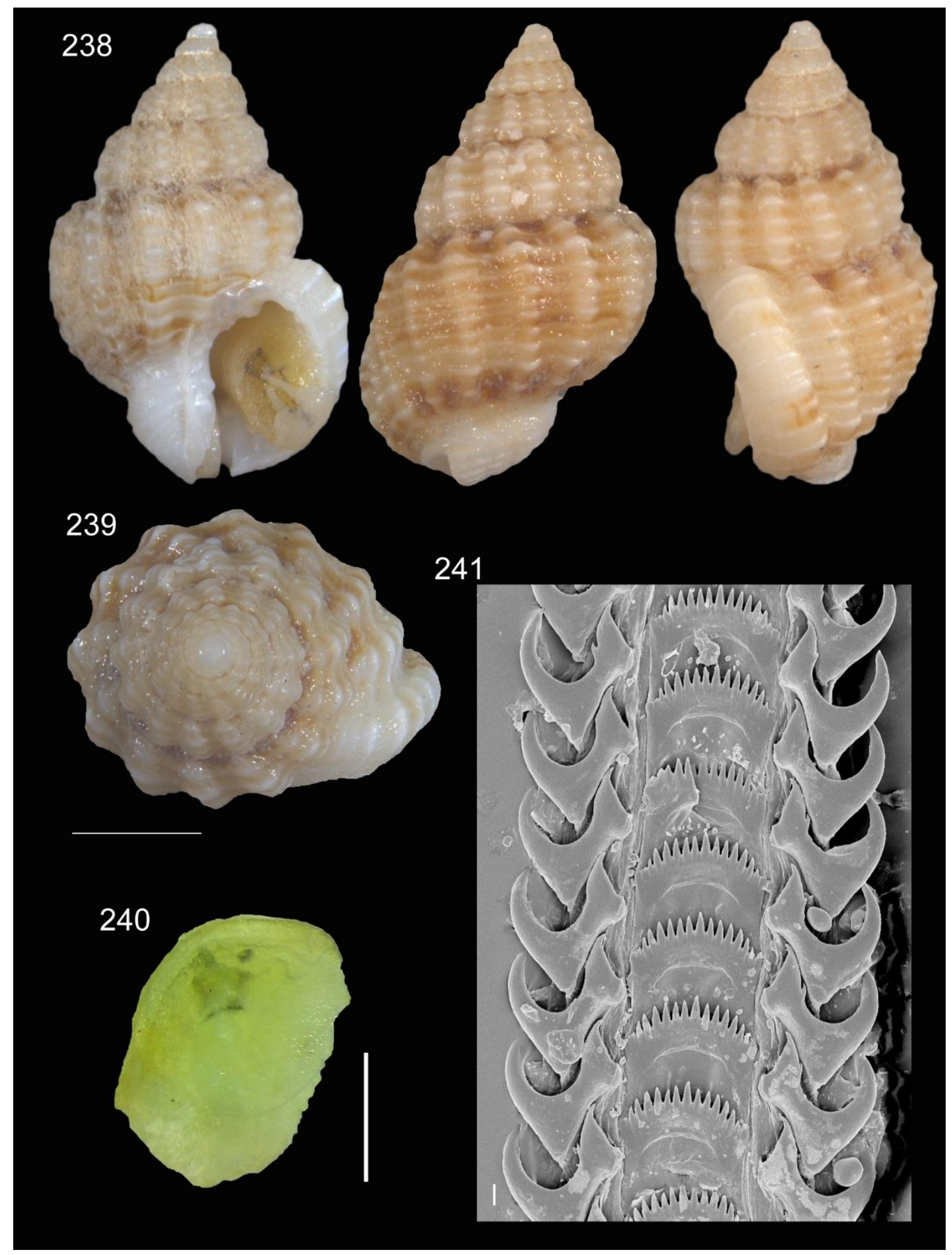

Figs. 238-241. Phrontis alba: UFM $4445077 \hat{\jmath}$, shell, operculum and radula; Figs 238: Adult specimen, Shell apertural, dorsal and lateral view (L 10,1 mm); Fig. 239: shell apical view; scale $=2 \mathrm{~mm}$; Fig. 240: Operculum dorsal view, scale $=2 \mathrm{~mm}$; Fig. 241; SEM of radula: Panoramic view of middle portion, scale $=30 \mu \mathrm{m}$. 


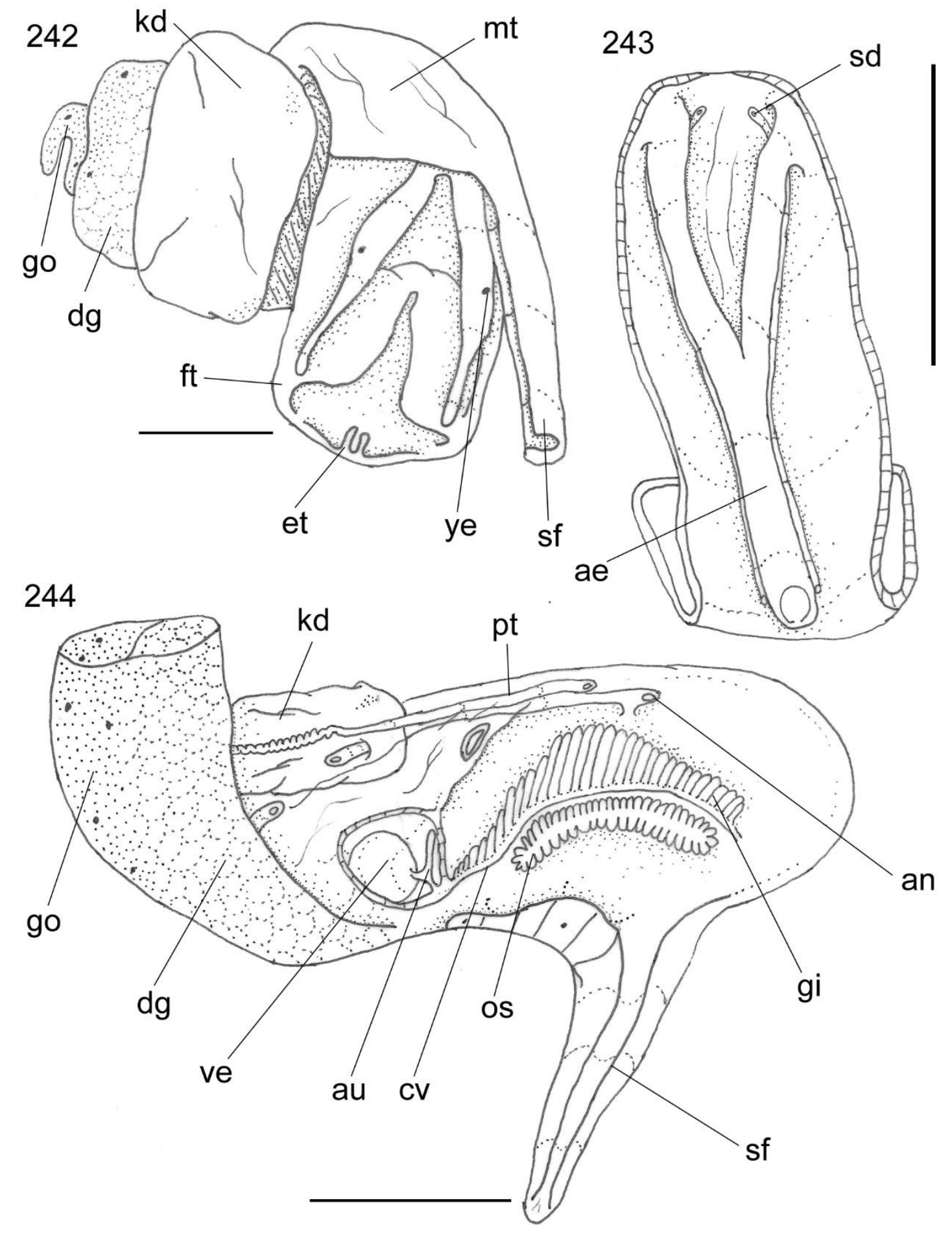

Figs. 242-244. Phrontis alba: Details of anatomy, Fig. 242: complete specimen extracted from shell (operculum removed), anterior-right view; Fig. 243: Proboscis and anterior esophagus opened longitudinally, showing salivary ducts and their apertures; Fig. 244: Pallial cavity roof, ventral view; Scales $=2 \mathrm{~mm}$. 

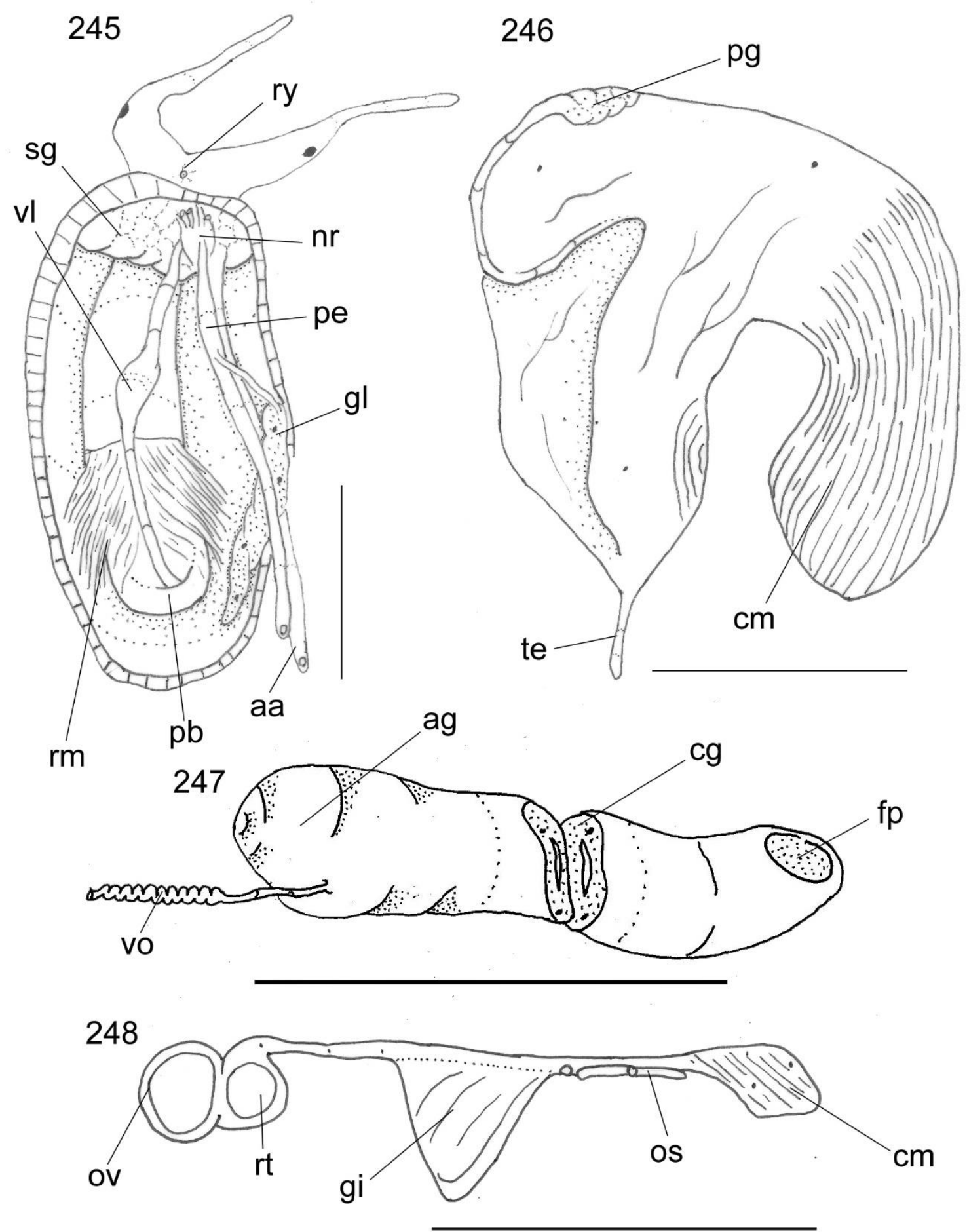

Figs. 245-248. Phrontis alba: Details of anatomy, Fig. 245: Head and haemocoel, ventral view, foot and columellar muscle removed; Fig. 246: Foot of female, sagittal section; Fig. 247: Pallial oviduct, right lateral view; Fig. 248: Pallial cavity roof, transverse section at middle level of osphradium. Scales $=2 \mathrm{~mm}$. 

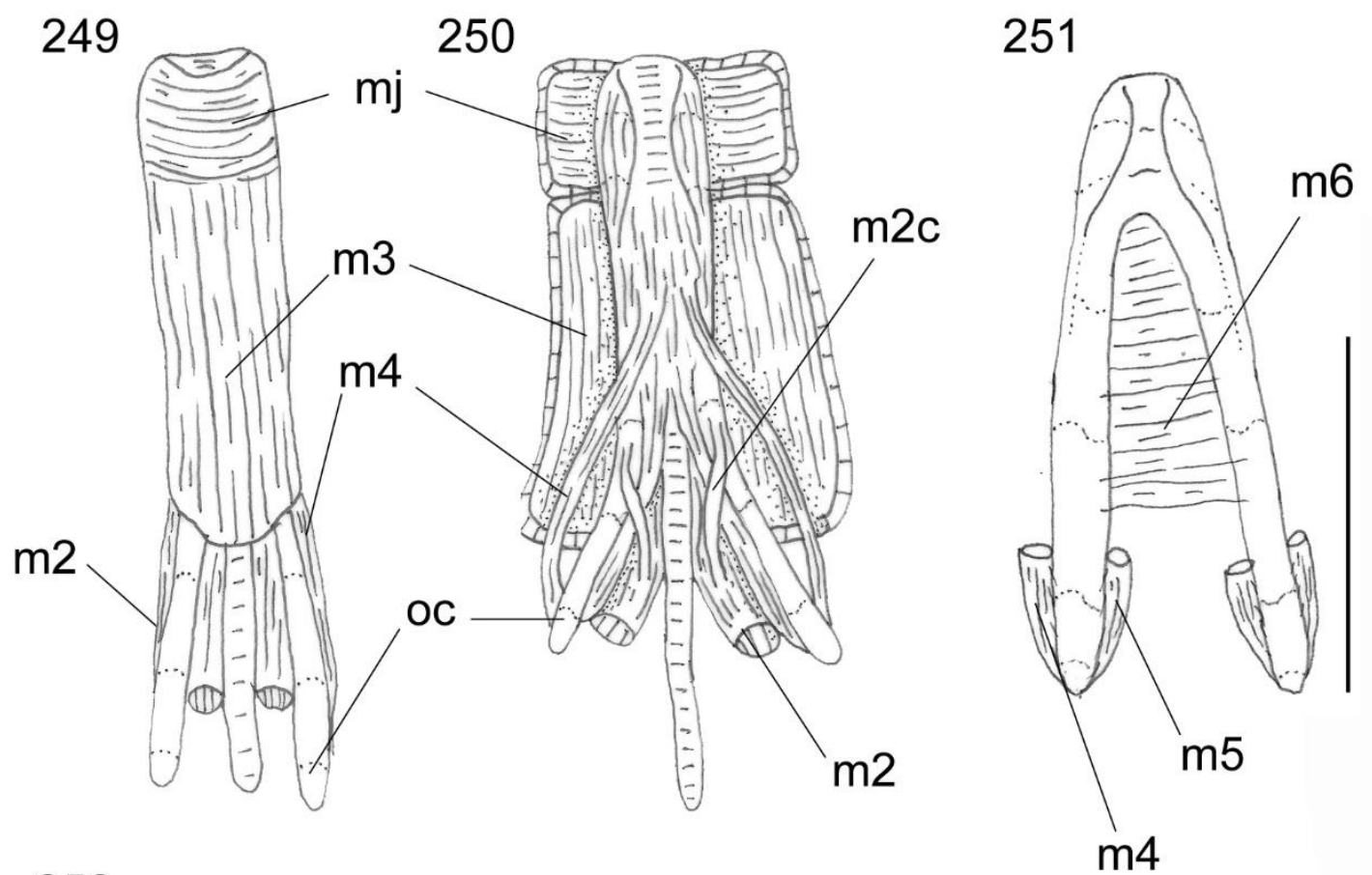

252

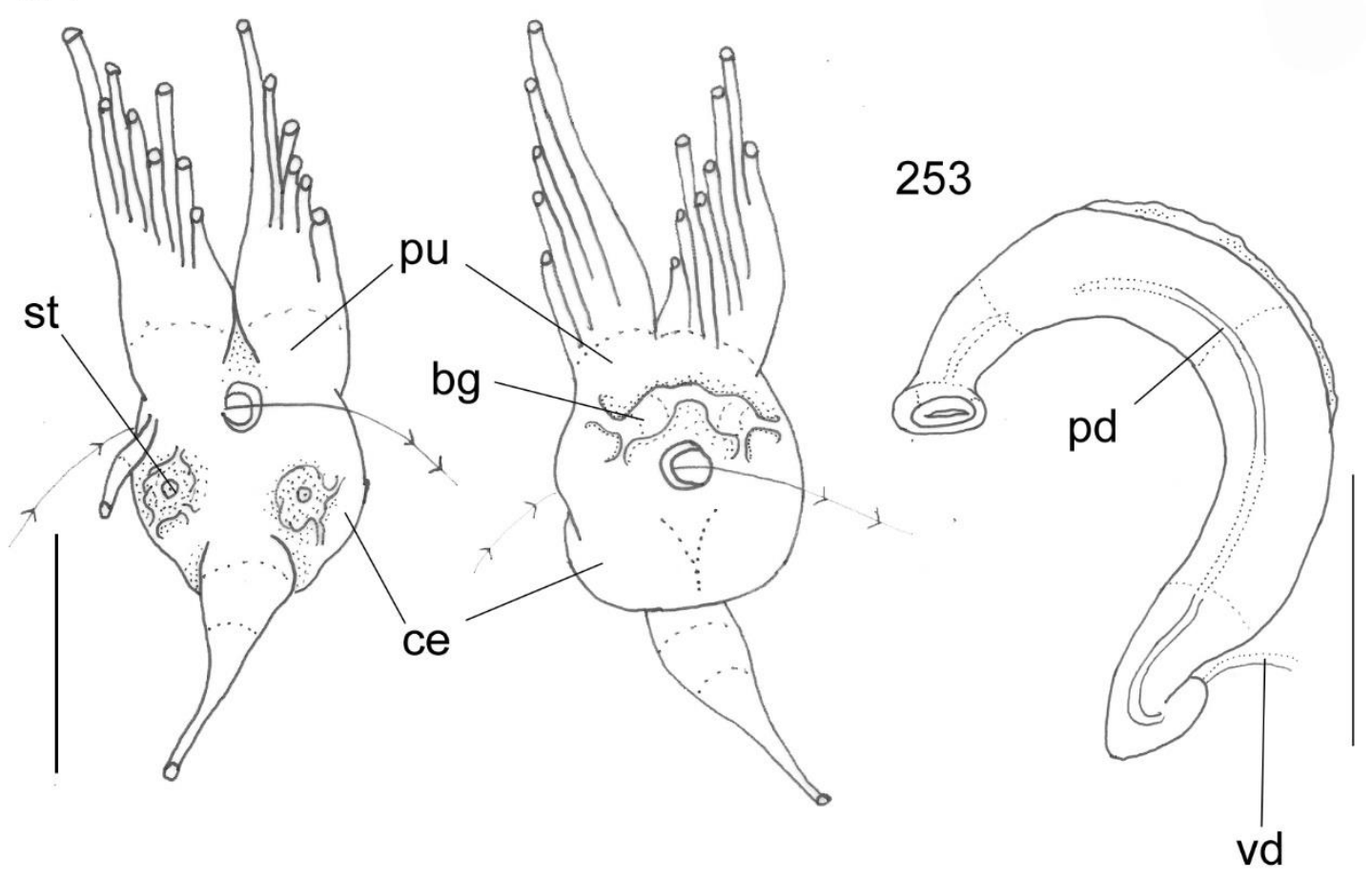

Figs. 249-253. Phrontis alba: Details of anatomy, Fig. 249: Odontophore, dorsal view, superficial layers showed; Fig. 250: Odontophore, dorsal view, superficial muscles dissected; Fig. 251: Odontophore cartilages, associated muscles shown; Fig. 252: Nerve ring, ventral and dorsal views; Fig. 253: Penis, lateral left view; Scales $=2 \mathrm{~mm}$. 


\section{Prontis sp. 1}

Figs. 254-268.

Shell (Figs. 254, 255). Ovate, about twice long as wide, spire high, with 7 convex whorls; color light yellow with white spots. Protoconch smooth, amber, with about three and a half whorls; transition to teleoconch hardly indicated by a depression and by the difference of sculpturing. Teleoconch sculpture composed of light orange axial ribs along entire surface and white spiral nodules along surface of all whorls, spire angle $\sim 55^{\circ}$, shoulder absent. Aperture prosocline, rounded, posteriorly acuminate, ca. 1/3 of shell length; color white; outer lip thick, palatal wall smooth; parietal rib strongly present; Parietal shield weakly developed; Anal notch weakly marked. Siphonal canal short, strong, deep, narrow $\sim 1 / 3$ of aperture length and dorsally recurved.

Head-foot (Figs. 257, 259). Pallial cavity covering 1/3 of total animal length; muscular siphon located on left, length $\sim 1 / 2$ of head-foot length. Head inlaid; tentacles closed from each other, elongated and narrow; eyes simple, located in medium region of tentacles. Foot long, occupying about of entire length of body whorl (retracted), flat, bearing a pair of thick and short medium metapodial tentacles; pedal gland located in middle region of foot (Fig.), forming a groove, extending to dorsum of foot (propodium). Opercular pad occupying 1/8 of dorsal area of foot, oval. Penis originated in right lateral region, posterior to cephalic base, at level of mantle edge, twice longer than animal length. Columellar muscle small and broad, 1/2 whorl long. Haemocoel long and thin, extending dorsally along center of foot and columellar muscle, 2x as long as wide (Fig.).

Operculum. Small size, ovate, horny, delicated, translucent amber; occupying almost entire aperture. Nucleus terminal, inferior. Outer surface with normal concentric growth lines, forming undulations. Scar elliptical, occupying about $2 / 3$ of inner surface, located close to edge of foot, outer edge serrated.

Mantle organs (Figs. 260, 261). Mantle cavity covering $~ 1$ whorl. Siphon width $1 / 2$ of mantle cavity width, length $1 / 2$ of mantle cavity length. Right base of siphon high, width about three times as mantle edge width; left base low. Osphradium short and thin, elliptical, length $\sim 1 / 3$ of pallial cavity length, width $\sim 1 / 4$ of its width. Osphradial filaments short, broad. Ctenidial vein (efferent branchial vessel) uniformly narrow along its length. Gill long and thin, occupying $~ 1 / 2$ of length and 1/4 of width of pallial cavity. Anterior end of gill rounded, ending directed in the mantle. Gill filaments uniformly narrow along its length. Posterior end of gill tapered, located in posterior region of mantle cavity, inserted into pericardium. Gill filaments high and triangular. Hypobranchial gland 
not visualized. Right side of pallial cavity almost entirely filled by gonoducts. Rectum short and thin, occupying $\sim 1 / 3$ of pallial cavity width. Anus as a simple pore, distance between anus and mantle border 1/2 of total pallial cavity length. Anal gland absent.

Visceral mass (Fig. 261). About 1 1/2 whorls posterior to mantle cavity. Digestive gland dark beige, occupying $~ 80 \%$ of visceral mass, encircling stomach. Gonad orange with small black spots, located on columellar surface, posterior to stomach. Seminal vesicle of males located in anterior portion of gonad, $\sim 1 / 2$ of its size. Kidney occupying $\sim 1 / 2$ of visceral mass volume, located on right side of anterior visceral end. Stomach not seem in detail.

Circulatory and excretory systems (Fig. 260, 261). Reno-pericardial region occupying 1 whorl, adjacent to mantle cavity; square shaped. Pericardium occupying 1/4 of reno-pericardial region, posterior to gill; situated on left anterior margin of visceral mass. Auricle membranous, anterior to ventricle; with three connections: on upper right side with kidney, on anterior right side with gill, and on posterior left side with ventricle. Ventricle three times as large as auricle, with common aorta in left posterior margin. Aorta thin, located along postero-left region of ventricle, anterior aorta with twice diameter of posterior aorta. Kidney occupying $1 / 3$ of pallial cavity length, renal lobe single, solid; efferent renal vessel located at its right portion. Nephridial gland not seen in detail. Nephrostome small, longitudinal slit, located in anterior region of membrane between kidney and pallial cavity.

Digestive system (Figs. 258, 262-266). Mouth longitudinal, narrow. Proboscis straight, short and thin, occupying about $90 \%$ of haemocoel volume. Rhynchodeal wall thin and membranous, involving $\sim 2 / 3$ of proboscis. Pairs of thin retractor muscles covering almost posterior end of proboscis. Salivary glands located at anterior portion of haemocoel, occupying $~ 1 / 4$ of haemocoel volume, entirely involving nerve ring, middle esophagus and anterior portion of proboscis. Salivary ducts very narrow, running completely attached to anterior esophagus wall and, more anteriorly, inside dorsal wall of buccal cavity; opening small, closed to the mouth. Valve of Leiblein medium, about 1/6 of proboscis length, located in medium esophagus anterior to nervous ring, diameter about 1/3x of the medium esophagus, anterior region with transverse white band bearing long cilia, middle and posterior regions white, corresponding to inner gland that occupies most of inner surface. Gland of Leiblein narrow and elongated, $\sim 3 \mathrm{x}$ longer than middle esophagus, duct of Gland of Leiblein, long and thin. Accessory salivary glands absent. Anterior esophagus thin uniformly narrow along its length; walls muscular, without 
internal folds, occupying entire length of proboscis. Middle esophagus with a bulging in the posterior region; posterior esophagus $\sim 90 \%$ of total haemocoel lenght, thin, with constant diameter along its entire length, differentiation between middle and posterior esophagus not clear. Stomach and digestive gland ducts not analyzed in detail.

Odontophore and buccal mass muscles: $m j$, thick of perioral muscles connected on both sides, dorsal and ventral, surrounding odontophore cartilages; $m 1$, jugal muscles, several tinny and thin fibers which connected odontophore in proboscis wall; $m 2$, Strong protractor muscles of buccal mass, originating on inner surface of proboscis, running along entire odontophore, inserting in anterior region of odontophore cartilages; $m 2 a$, pair of retractor muscles of buccal mass, originating on dorsal surface of haemocoel, inserting at end of posterior margin of odontophore cartilages; $m 2 b$, absent; $m 3$, long and cylindrical muscle forming outer wall of odontophore, with transverse fibers; $m 4$, pairs of strong radular dorsal tensor muscles covering almost entire surface of posterior portion of odontophore cartilages, originating outside edges of cartilage and inserting into subradular membrane; $m 5$, pair of auxiliary dorsal tensor muscles of radula, originating inside edges of cartilage, adjacent to $\mathrm{m} 4$ insertion; $m 6$, horizontal muscle, thick, connecting ventral edges of cartilages, running about entire of their length; $m 8$, pair of elliptical small muscles, $\sim 1 / 7$ of total length of odontophore, originating at anterior end of odontophore cartilages, running along ventral surface of odontophore, inserting on anterior ventral surface of cartilages; $m 11$, pair of ventral tensor muscles of radula, about $1 / 2$ of total odontophore length, originating at ventral-posterior end of cartilages, crossing ventrally entire odontophore, inserting into ventral posterior surface of radula. Additional odontophore structures: $b r$, subradular membrane, thin, strong and translucent, along entire length of radular ribbon, covering inner surface of odontophore cartilages; $o c$, odontophore cartilages, about $2 \mathrm{x}$ long as wide, inner ventral surface concave, $\sim 1 / 5$ of anterior end fused with each other; $r s$, radular sac thin-walled, cylindrical, located at posterior end of radula; $n r$, radular nucleus width $\sim 1 / 2$ of radular sac width.

Radular teeth (Figs). Rachidian tooth narrow, comb-like, occupying about $1 / 3$ of radular width; base curved, width about half of its length; $~ 9$ triangular, sharp pointed cusps of similar size, except for some diminishment towards the side; lateral tooth hooklike, with two cusps, base broad (equivalent twice of rachidian base width), obliquely disposed; main lateral cusp widely curved inwards, about as long as base; secondary cusp approximately half size of main cusp, divided into two smaller cusps decreasing in size towards center; radula ribbon equal between males and females; jaws absent. 
Genital system. Male (Fig. 268). Vas deferens narrow, simple, straight, running along ventral surface of kidney up to pallial cavity. Prostate totally closed (tubular), running thought right mantle edge, at $\sim 1 / 3$ of total pallial cavity length. Vas deferens anterior to prostate, straight, running immersed into integument of dorsum, next to mantle border and penis base. Penis long, slender, about twice of total animal length, dorsoventrally flattened and with proportional diameter throughout its length; base curved, apical region thin with a terminal curved big papilla. Penial duct straight, running through center of penis, closed (tubular). Penial aperture distal, at the base of papilla, small.

Female (Figs. 260, 261). Visceral oviduct narrow, sinuous, running along dorsal surface of kidney in first whorl of visceral mass, located in front of pallial cavity. Posterior region of pallial oviduct protruding into kidney, occupying $~ 2 / 3$ of length of pallial cavity and 1/5 of its width. Albumen gland posterior, whitish, thin-walled, occupying $\sim 1 / 3$ of pallial oviduct. Capsule gland $\sim 2 / 3$ of oviduct, elongated, orange, thick-walled, female genital pore like a slit. Bursa copulatrix absent. Cement gland absent.

Central nervous system (Fig. 267). Nerve ring located in ventral anterior proboscis region, occupying 1/12 of haemocoel volume, highly concentrated. Ganglia mostly fused, hard to distinguish from each other, somewhat asymmetrical. Pairs of pleural and cerebral ganglia fully fused with each other. Sub-esophageal ganglia small, about 1/9 of nerve ring volume. Esophageal aperture small, central, located in middle region of pleural and cerebral ganglia. Pair of small Statocysts located at ventral surface of pleural ganglia, formed by a sand grain enveloped by mucus.

Shell measurements (length $x$ width in $\mathrm{mm}$ ): 1 đ 8.9 x 5.1; 2 q 9.8 x 5.6; 9.9 x 6.0.

Distribution: Queimada Grande Island, São Paulo, Brazil.

Habitat: Fine and Sand Bottoms, intertidal.

Material examined: MZSP 35706; 1ठ, 2, Brazil, São Sebastião: Queimada Grande Island, 50-60 m depth (Arrasto viii/2002). 


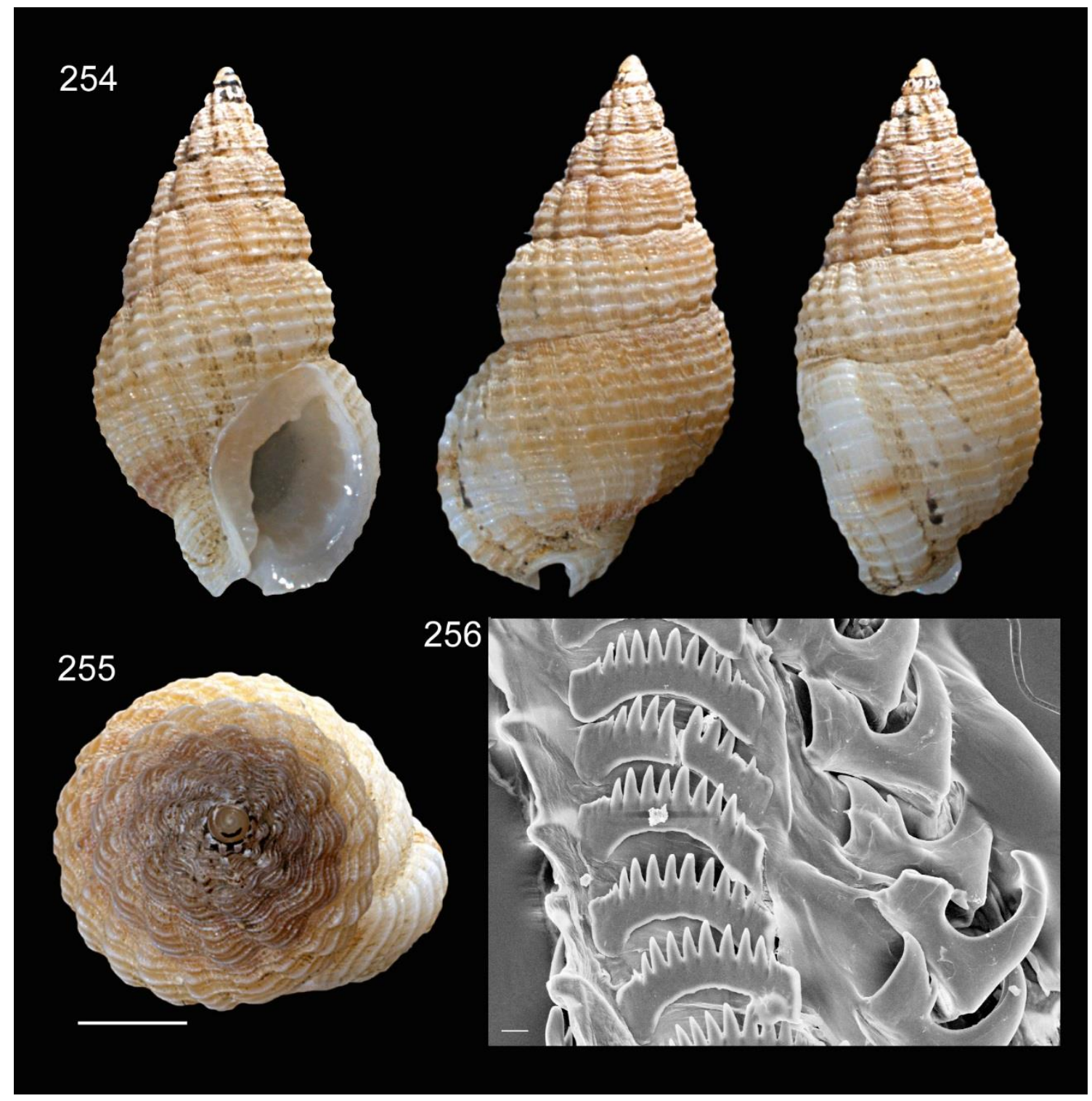

Figs. 254-256. Phrontis sp. 1: MZSP 35706 , shell and radula; Figs 254: Adult specimen, Shell apertural, dorsal and lateral view (L 9,8 mm); Fig. 255: shell apical view; Scale = $2 \mathrm{~mm}$; Fig. 256; SEM of radula: Panoramic view of middle portion, scale $=30 \mu \mathrm{m}$. 


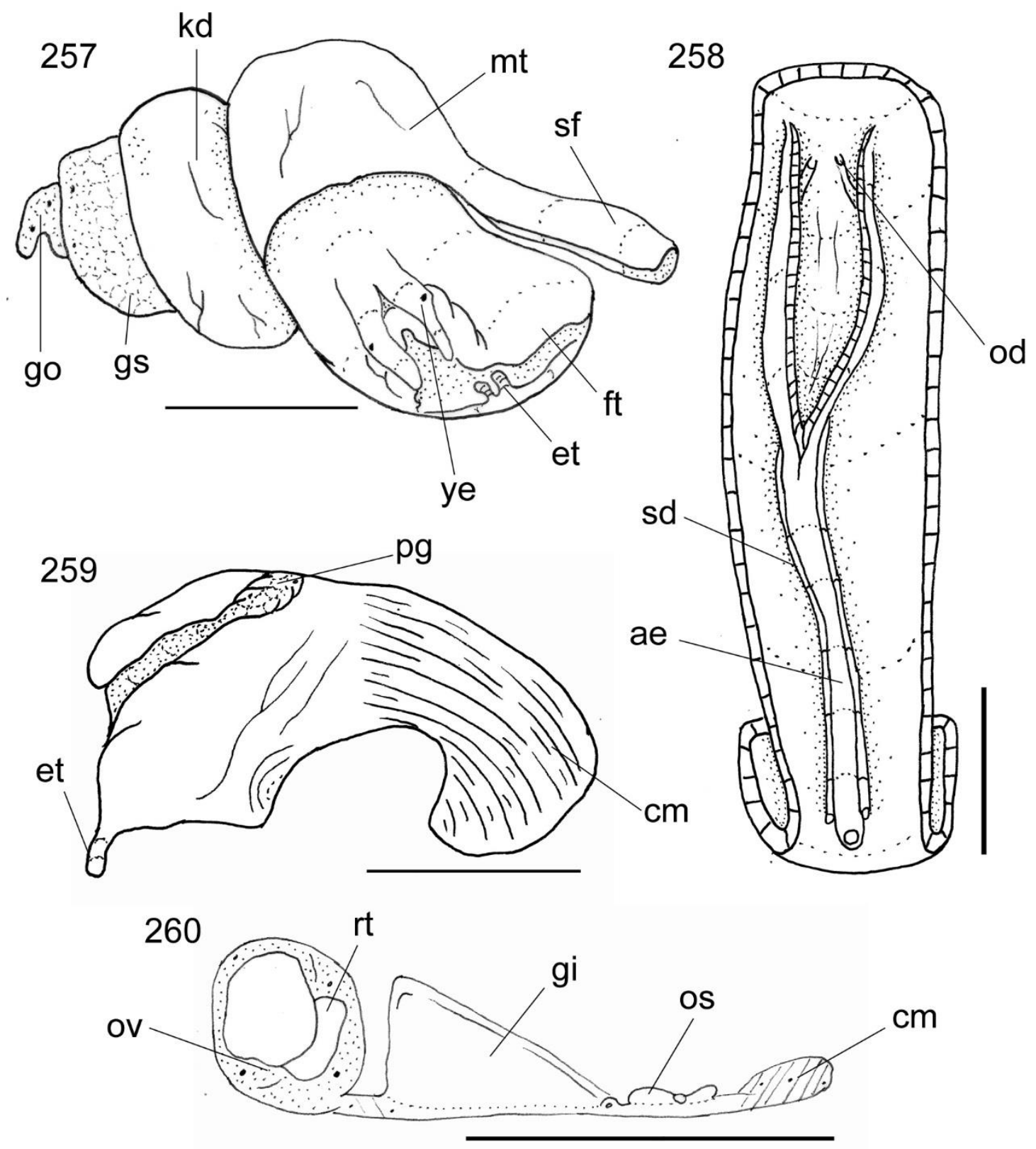

Figs. 257-260. Phrontis sp. 1: Details of anatomy, Fig. 257: complete specimen extracted from shell (operculum removed), anterior-right view; Fig. 258: Proboscis and anterior esophagus opened longitudinally, showing salivary ducts and their apertures; Fig. 259: Foot of female, sagittal section; Fig. 260: Pallial cavity roof, transverse section at middle level of osphradium. Scales $=2 \mathrm{~mm}$. 


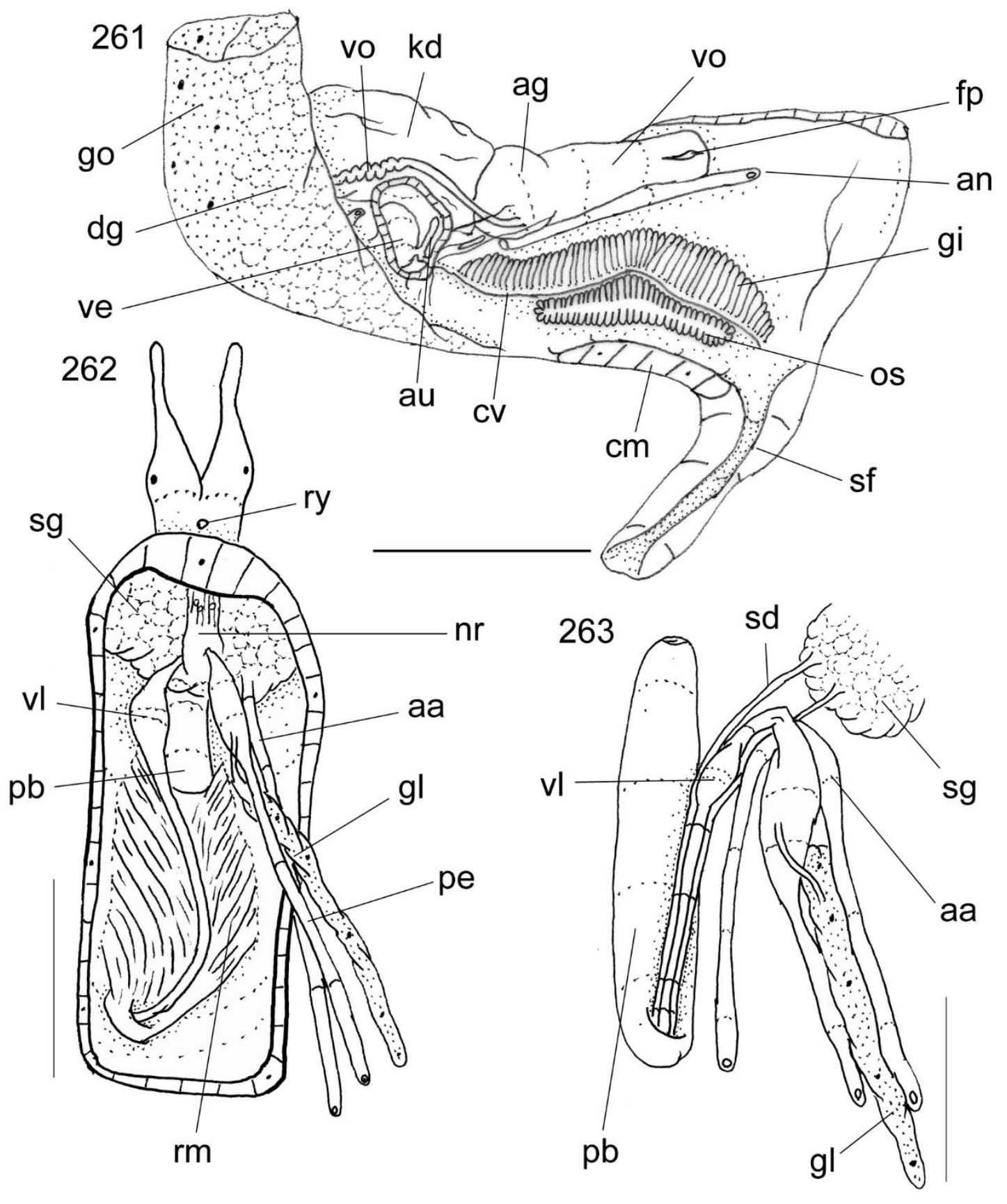

Figs. 261-263. Phrontis sp. 1: Details of anatomy, Fig. 261: Pallial cavity roof, ventral view; Fig. 262: Head and haemocoel, ventral view, foot and columellar muscle removed; Fig. 263: Detail of fore and midgut, associated structures also shown; Scales $=2 \mathrm{~mm}$. 

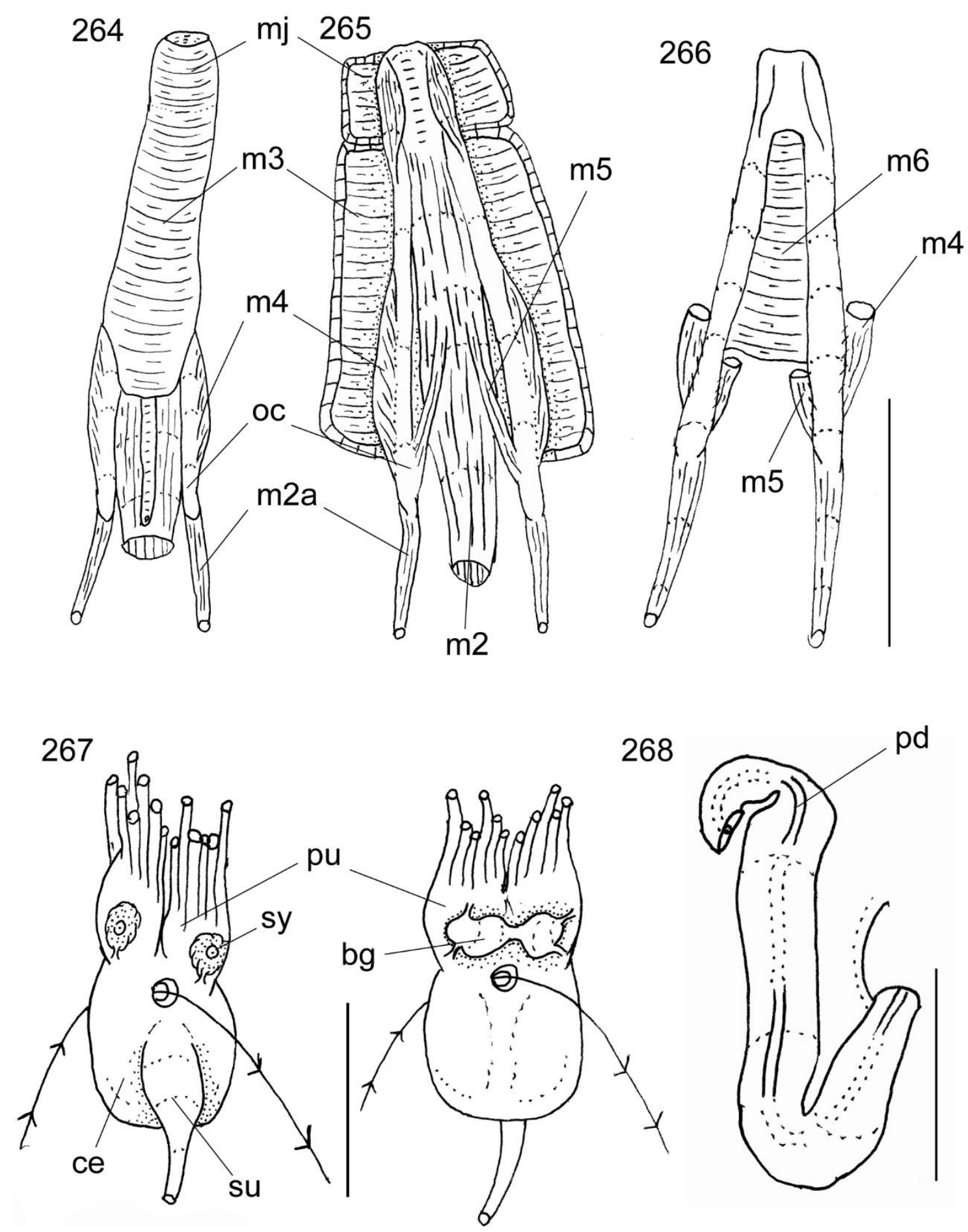

Figs. 264-268. Phrontis sp. 1: Details of anatomy, Fig. 264: Odontophore, dorsal view, superficial layers showed; Fig. 265: Odontophore, dorsal view, superficial muscles dissected; Fig. 266: Odontophore cartilages, associated muscles shown; Fig. 267: Nerve ring, ventral and dorsal views; Fig. 268: Penis, lateral left view. Scales $=2 \mathrm{~mm}$. 


\section{Phrontis sp. 2}

Figs. 269-283.

Shell (Figs. 269, 270). Ovate, about twice long as wide, with 5 convex whorls; color, light yellow and white, with cream and light orange bands in the middle region of whorls. Protoconch bid, smooth, white, with three whorls; transition to teleoconch hardly indicated by a depression and by the difference of sculpturing. Teleoconch sculpture composed of light orange axial ribs along entire surface and white spiral nodules near the sutures, spire angle $\sim 47^{\circ}$, shoulder absent. Aperture prosocline, rounded, posteriorly acuminate, ca. $1 / 3$ of shell length; color white; outer lip thick, palatal wall smooth; parietal rib weakly present; Parietal shield absente; Anal notch weakly marked. Siphonal canal short, strong, deep, narrow ( 1/3 of aperture length) and dorsally recurved.

Head-foot (Figs. 272, 278). Pallial cavity covering 1/2 of total animal length; muscular siphon located on left, length $\sim 1 / 3$ of head-foot length. Head protruded; tentacles separated from each other, elongated and narrow, $3 \mathrm{x}$ as long as head; eyes pedunculated, located in medium region of tentacles. Foot small, occupying half of body whorl (retracted), flat, bearing a pair of medium metapodial tentacles; pedal gland located in anterior edge of foot, forming a groove, extending to dorsum of foot (propodium). Opercular pad occupying 1/8 of dorsal area of foot, oval. Penis originated in right lateral region, posterior to cephalic base, at level of mantle edge. Columellar muscle small and broad, 1/2 whorl long. Haemocoel long and broad, extending dorsally along center of foot and columellar muscle, $2 \mathrm{x}$ as long as wide.

Operculum. Small, ovate, horny, amber, semi-translucent; occupying about $70 \%$ of aperture. Nucleus terminal, inferior. Outer surface with normal concentric growth lines, forming undulations. Scar elliptical, occupying about $2 / 3$ of inner surface, located close to edge of foot; expansions in the form of spines on posterior end.

Mantle organs (Figs. 274, 275). Mantle cavity covering 1 1/2 whorl. Siphon width $1 / 3$ of mantle cavity width, length $3 / 4$ of mantle cavity length. Right base of siphon high, width about three times as mantle edge width; left base high, ending in a fold close to the gill's anterior region. Osphradium short and wide, elliptical, length $1 / 3$ of pallial cavity length, width $\sim 1 / 6$ of its width. Osphradial filaments short, broad. Ctenidial vein (efferent branchial vessel) uniformly narrow along its length. Gill long and wide, occupying 95\% of length and 1/3 of width of pallial cavity. Anterior end of gill rounded, ending gradually, inserted directly into pallial cavity. Gill rectangular. Anterior end of gill tapered. Gill filaments low and triangular. Hypobranchial not analized. Right side of pallial cavity 
almost entirely filled by gonoducts. Rectum long and thin, occupying $~ 2 / 3$ of pallial cavity width. Anus siphoned, distance between anus and mantle border $1 / 3$ of total pallial cavity length. Anal gland absent.

Visceral mass (Figs. 274). About $21 / 2$ whorls posterior to mantle cavity. Digestive gland dark beige, occupying $~ 80 \%$ of visceral mass, encircling stomach. Gonad orange with small black spots, located on columellar surface, posterior to stomach. Seminal vesicle of males located in anterior portion of gonad, $\sim 1 / 2$ of its size. Kidney occupying $\sim 1 / 2$ of visceral mass volume, located on right side of anterior visceral end. Stomach small, located half whorl in front of pallial cavity.

Circulatory and excretory systems (Fig. 274, 275). Reno-pericardial region occupying 1 whorl, adjacent to mantle cavity; square shaped. Pericardium occupying 1/5 of reno-pericardial region, posterior to gill; situated on left anterior margin of visceral mass. Auricle triangular membranous, auricular connections not seen in details. Ventricle four times as large as auricle, with common aorta in left posterior margin. Aorta thin, located along postero-left region of ventricle, anterior aorta with twice diameter of posterior aorta (Fig.). Kidney occupying 1/3 of pallial cavity length, renal lobe single, solid; efferent renal vessel located at its right portion. Nephridial gland with the same kidney length. Nephrostome small, transversal slit, located in anterior region of membrane between kidney and pallial cavity.

Digestive system (Figs. 273, 276, 277, 279, 280-282). Mouth longitudinal, narrow. Proboscis short and broad, occupying about $90 \%$ of haemocoel volume. Rhynchodeal wall thick, involving $2 / 3$ of proboscis. Thin retractor muscles covering posterior end of proboscis. Salivary glands located at anterior portion of haemocoel, occupying $\sim 1 / 5$ of haemocoel volume, entirely involving nerve ring, middle esophagus and anterior portion of proboscis. Salivary ducts very narrow, running completely attached to anterior esophagus wall and, more anteriorly, inside dorsal wall of buccal cavity along the folds; opening very small, located in the middle region of oral tube. Valve of Leiblein small, about $1 / 8$ of proboscis volume, located in medium esophagus anterior to nervous ring, diameter about $1 \mathrm{x}$ of the medium esophagus, anterior region with transverse white band bearing long cilia, middle and posterior regions white, corresponding to inner gland that occupies most of inner surface. Gland of Leiblein narrow and elongated, 2x longer than middle esophagus, uniformly narrow along its length, duct of Gland of Leiblein, short and narrow. Accessory salivary glands absent. Anterior esophagus thin uniformly narrow along its length; walls muscular, with two strong internal longitudinal folds, occupying 
entire length of proboscis. Middle esophagus with the same diameter of anterior esophagus; posterior esophagus $\sim 90 \%$ of total haemocoel lenght, thin, with constant diameter along its entire length, differentiation between middle and posterior esophagus not clear. Stomach and digestive gland ducts not analyzed in detail.

Odontophore and buccal mass muscles: $m j$, thick of perioral muscles connected on both sides, dorsal and ventral, surrounding odontophore cartilages short, about 1/4 of odontophore length,; $m 1$, jugal muscles, several tinny and thin fibers which connected odontophore in proboscis wall; $m 2$, Strong protractor muscles of buccal mass, originating on inner surface of proboscis, running along entire odontophore, inserting in anterior region of odontophore cartilages; $m 2 a$, pair of retractor muscles of buccal mass, originating on dorsal surface of haemocoel, inserting at end of posterior margin of odontophore cartilages; $m 2 b$, absent; $m 3$, long and cylindrical muscle forming outer wall of odontophore, with transverse fibers; $m 4$, pairs of thin, strong radular dorsal tensor muscles covering almost entire surface of posterior portion of odontophore cartilages, originating outside edges of cartilage and inserting into subradular membrane; $m 5$, pair of thin auxiliary dorsal tensor muscles of radula, originating inside edges of cartilage, adjacent to $\mathrm{m} 4$ insertion; $m 6$, horizontal muscle, thin, connecting ventral edges of cartilages, running $\sim 2 / 3$ of their length; $m 8$, pair of elliptical muscles, $\sim 1 / 5$ of total length of odontophore, originating at anterior end of odontophore cartilages, running along ventral surface of odontophore, inserting on anterior ventral surface of cartilages; $m 11$, pair of ventral tensor muscles of radula, about $1 / 3$ of total odontophore length, originating at ventral-posterior end of cartilages, crossing ventrally entire odontophore, inserting into ventral posterior surface of radula. Additional odontophore structures: $b r$, subradular membrane, thin, strong and translucent, along entire length of radular ribbon, covering inner surface of odontophore cartilages; $o c$, odontophore cartilages, square shaped, about $2 \mathrm{x}$ long as wide, inner ventral surface concave, $\sim 1 / 4$ of anterior end fused with each other.

Radular teeth (Fig. 271). Rachidian tooth wide, comb-like, occupying about half of radular width; base curved, length $\sim 3 \times$ its width; $\sim 20$ triangular, sharp pointed cusps of similar size, except for some diminishment towards the side; lateral tooth hook-like, with two cusps, base broad (equivalent to rachidian base width), obliquely disposed; main lateral cusp widely curved inwards, about as long as base; secondary cusp approximately 1/2 size of main lateral cusp with 3 small cusps, two of same size and another bigger; radula ribbon equal between males and females; jaws absent.

Genital system. Male. Not analyzed 
Female (Figs. 274, 275, 282). Visceral oviduct thin, narrow, straight, running along dorsal surface of kidney in first whorl of visceral mass, located in front of pallial cavity. Pallial oviduct small, protruding into kidney, occupying $\sim 1 / 3$ of length of pallial cavity and $1 / 5$ of its width. Albumen gland posterior, whitish, thick-walled, occupying $\sim 1 / 5$ of pallial oviduct. Capsule gland $\sim 4 / 5$ of oviduct, elongated, orange, thick-walled. Vaginal atrium wide, quadrangular, tubular, occupying $~ 1 / 5$ of oviduct; walls thick, muscular, female genital pore like a slit on the side wall of pallial oviduct. Bursa copulatrix absent. Cement gland absent (Fig.).

Central nervous system (Fig. 283). Nerve ring located in ventral anterior proboscis region, occupying $~ 1 / 12$ of haemocoel volume, highly concentrated. Ganglia mostly fused, hard to distinguish from each other, somewhat symmetrical. Pairs of pleural and cerebral ganglia fully fused with each other. Sub-esophageal not seen in detail. Esophageal aperture small, central, located in midlle region of pleural and cerebral ganglia, occupying about $1 / 6$ of surface of nerve ring. Pair of statocysts located at ventral surface of pleural ganglia.

Shell measurements (length $x$ width in $\mathrm{mm}$ ): 4 + $10.1 \times 5.6 ; 11.2 \times 6.3 ; 9.8 \times 5.8$; $10.1 \times 5.9$.

Distribution: Brazil, Pernambuco, Fernando de Noronha, Ponta da Sapata.

Habitat: Sand bottoms, intertidal.

Material examined: MZSP 213134, Brazil: Pernambuco, Fernando de Noronha; Ponta da Sapata (Simone col. 18/vii/1999). 


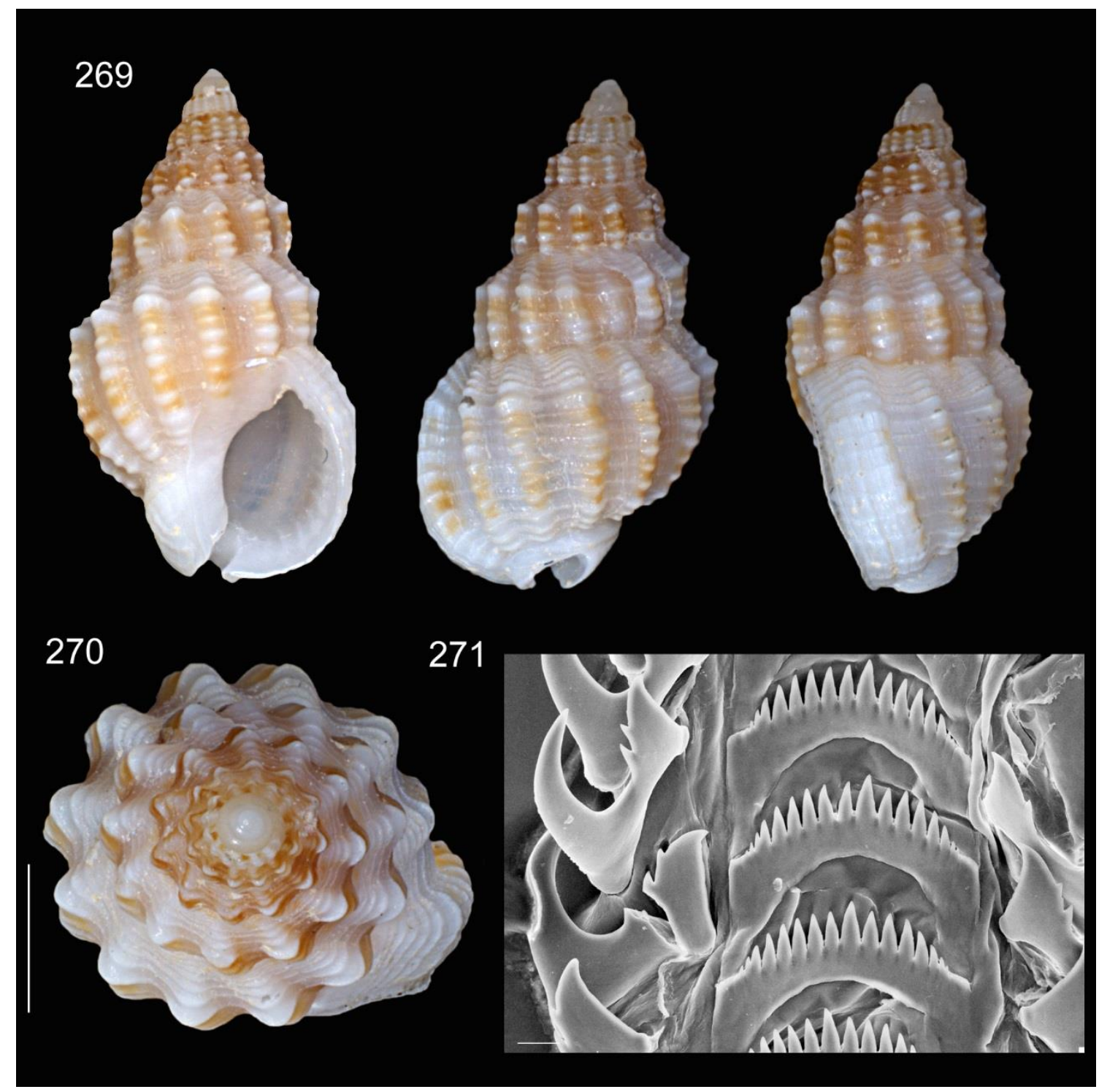

Figs. 269-271. Phrontis sp. 2: MZSP 213134 , shell and radula; Figs 269: Adult specimen, Shell apertural, dorsal and lateral view (L 10,1 mm); Fig. 270: shell apical view; Scale $=2$ mm; Fig. 271; SEM of radula: Panoramic view of middle portion, scale $=30 \mu \mathrm{m}$. 


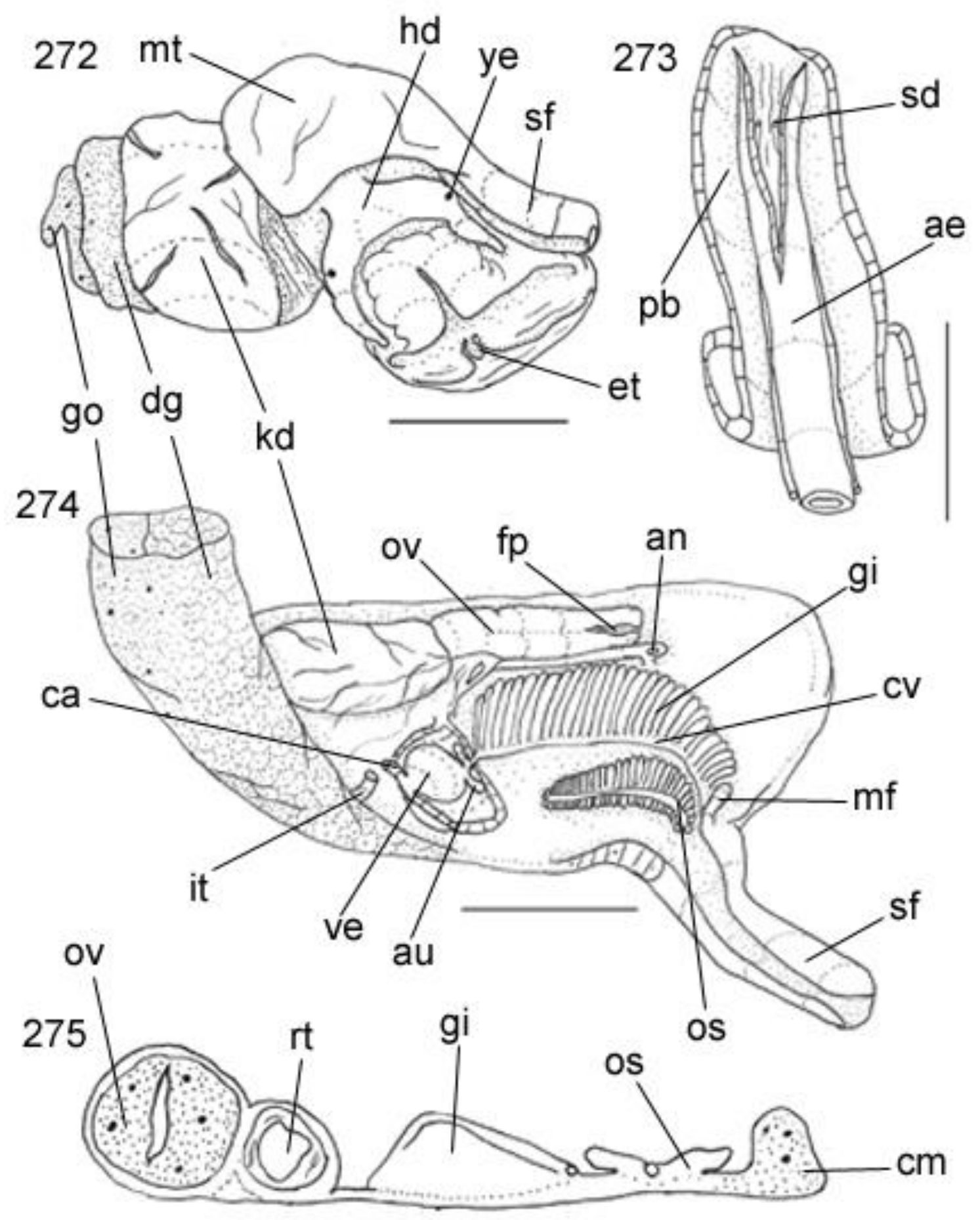

Figs. 272-275. Phrontis sp. 2: Details of anatomy, Fig. 272: complete specimen extracted from shell (operculum removed), anterior-right view; Fig. 273: Proboscis and anterior esophagus opened longitudinally, showing salivary ducts and their apertures; Fig. 274: Pallial cavity roof, ventral view; Fig. 275: Pallial cavity roof, transverse section at middle level of osphradium. Scales $=2 \mathrm{~mm}$. 

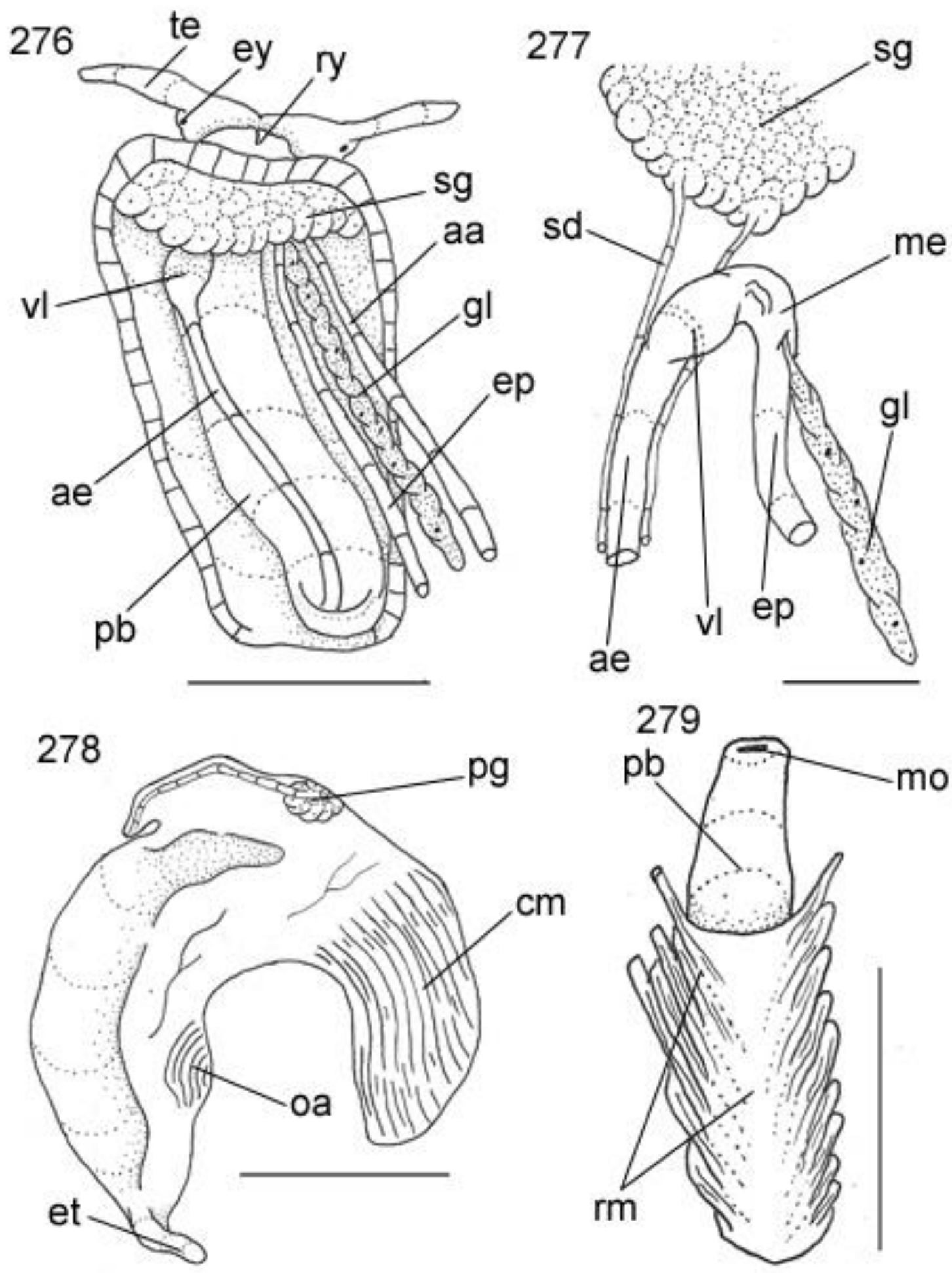

Figs. 276-279. Phrontis sp. 2: Details of anatomy, Fig. 276: Head and haemocoel, ventral view, foot and columellar muscle removed; Fig. 277: Detail of fore and midgut, associated structures also shown; Fig. 278: Foot of female, sagittal section; Fig. 279: Proboscis ventral view, retractor muscles also show; Scales $=2 \mathrm{~mm}$. 


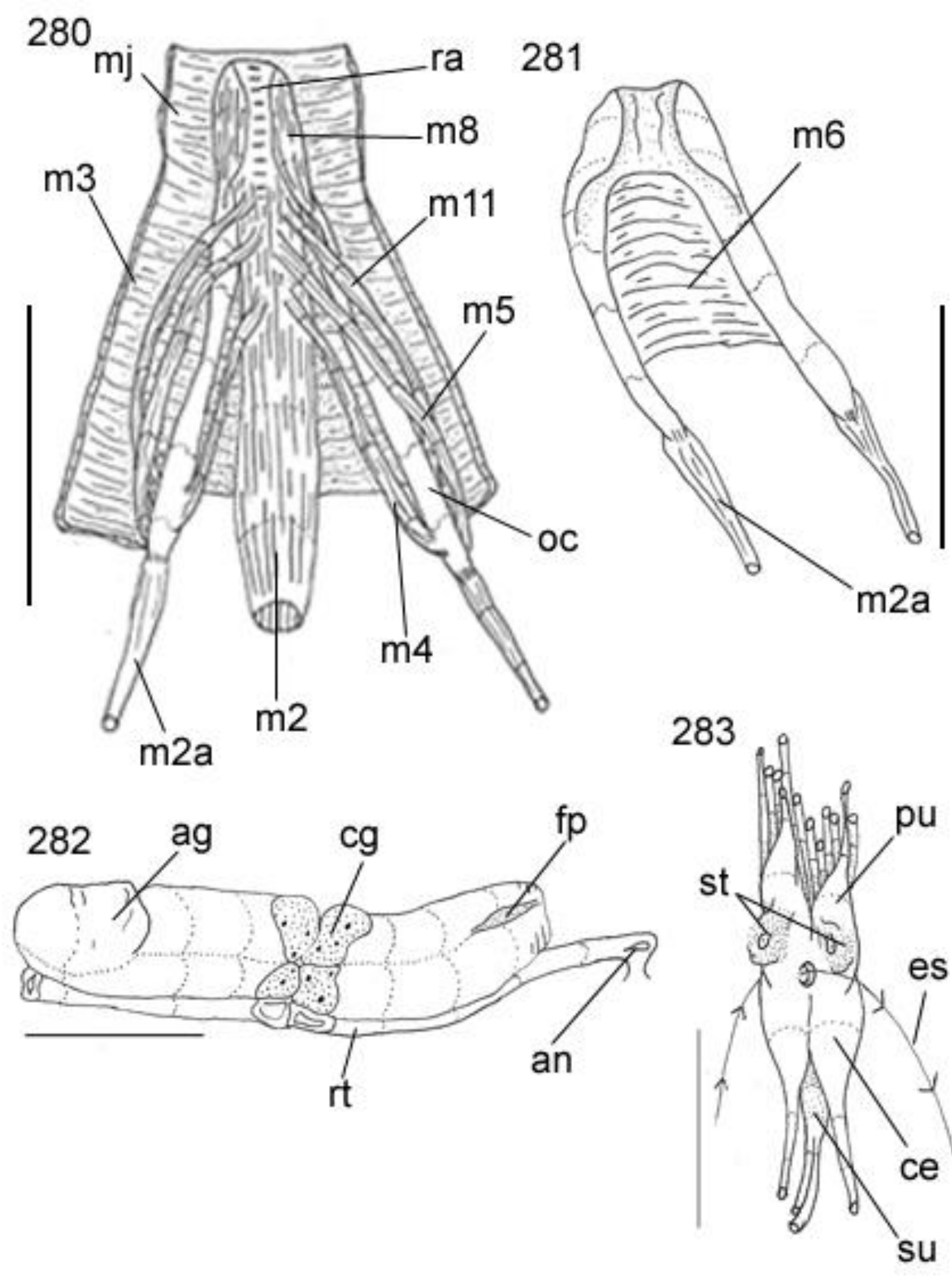

Figs. 280-283. Phrontis sp. 2: Details of anatomy, Fig. 280: Odontophore, dorsal view, superficial muscles dissected; Fig. 281: Odontophore cartilages, associated muscles shown; Fig. 282: Pallial oviduct, right lateral view; Fig. 283: Nerve ring, ventral view; Scales $=2 \mathrm{~mm}$. 


\section{Phrontis sp. 3}

Figs. 284-299.

Shell (Figs. 284, 285). Ovate, about twice long as wide, with 5 convex whorls; color, light yellow and white, with cream and light brown bands near the sutures. Protoconch big, smooth, cream, with three whorls; transition to teleoconch hardly indicated by a depression and by the difference of sculpturing. Teleoconch sculpture composed of light orange axial ribs along entire surface and white spiral nodules near the sutures, spire angle $\sim 47^{\circ}$, shoulder absent. Aperture prosocline, rounded, posteriorly acuminate, ca. $1 / 3$ of shell length; color white; outer lip thick, palatal wall smooth; parietal rib absent; Parietal shield absente; Anal notch weakly marked. Siphonal canal short, strong, deep, narrow ( 1/3 of aperture length) and dorsally recurved (Figs.).

Head-foot (Figs. 288, 291). Head protruded; tentacles closed from each other, elongated and narrow, $3 \mathrm{x}$ as long as head; eyes not pedunculated, located in medium region of tentacles. Foot small, occupying half of body whorl (retracted), flat, bearing a pair of large metapodial tentacles; pedal gland located in medium region of foot, forming a groove, extending to dorsum of foot (propodium). Opercular pad occupying 1/8 of dorsal area of foot, oval. Penis originated in right lateral region, posterior to cephalic base, at level of mantle edge. Columellar muscle small and broad, 1/2 whorl long. Haemocoel short and broad, extending dorsally along center of foot and columellar muscle, $2 \mathrm{x}$ as long as wide.

Operculum (Fig. 286). Small, ovate, horny, amber, semi-translucent; occupying about $70 \%$ of aperture. Nucleus terminal, inferior. Outer surface with normal concentric growth lines, forming undulations. Scar elliptical, occupying about $2 / 3$ of inner surface, located close to edge of foot; expansions in the form of spines on both sides, left and right.

Mantle organs (Figs. 290, 294). Mantle cavity covering 1 1/2 whorl. Siphon long and thin width $1 / 4$ of mantle cavity width, length same as of mantle cavity length. Right base of siphon high, width about three times as mantle edge width; left base low, ending directly in the mantle. Osphradiumsmall, narrow, elliptical, length $1 / 4$ of pallial cavity length, width $\sim 1 / 7$ of its width. Osphradial filaments short, broad. Ctenidial vein (efferent branchial vessel) uniformly narrow along its length. Gill long and narrow, occupying 1/2 of length and 1/5 of width of pallial cavity. Anterior end of gill rounded, ending gradually, inserted directly into pallial cavity. Gill rectangular. Anterior end of gill tapered. Gill filaments high and triangular. Right side of pallial cavity almost entirely filled by 
gonoducts. Rectum long and thin, occupying all pallial cavity lenght Anus pedunculated, closed to the mantle border. Anal gland absent.

Visceral mass (Fig. 290). Like previous species.

Circulatory and excretory systems (Figs. 290, 294). Reno-pericardial region occupying 1 whorl, adjacent to mantle cavity; square shaped. Pericardium occupying 1/4 of reno-pericardial region, posterior to gill; situated on left anterior margin of visceral mass. Auricle triangular membranous, auricular connections not seen in details. Ventricle four times as large as auricle, with common aorta in left posterior margin. Aorta thin, located along postero-left region of ventricle, anterior aorta with twice diameter of posterior aorta. Kidney occupying 1/3 of pallial cavity length, renal lobe single, divided into chambers. Nephrostome small, transversal slit, located in anterior region of membrane between kidney and pallial cavity.

Digestive system (Figs. 289, 292, 296-298). Mouth, proboscis, salivary gland and salivary ducts similar to anterior especies. Valve of Leiblein big, about 1/5 of proboscis volume, located in medium esophagus anterior to nervous ring, diameter about $1 \mathrm{x}$ of the medium esophagus, anterior region with transverse white band bearing long cilia, middle and posterior regions white, corresponding to inner gland that occupies most of inner surface. Gland of Leiblein wide and elongated, $\sim 2 \mathrm{x}$ longer than middle esophagus, uniformly narrow along its length, duct of Gland of Leiblein, short and narrow. Accessory salivary glands absent. Anterior esophagus same as Phrontis alba.

Odontophore and buccal mass muscles: $m j$, thick of perioral muscles connected on both sides, dorsal and ventral, surrounding odontophore cartilages short, about 1/4 of odontophore length,; $m 1$, jugal muscles, several tinny and thin fibers which connected odontophore in proboscis wall; $m 2$, Strong protractor muscles of buccal mass, originating on inner surface of proboscis, running along entire odontophore, inserting in anterior region of odontophore cartilages; $m 2 a$, pair of retractor muscles of buccal mass, originating on dorsal surface of haemocoel, inserting at end of posterior margin of odontophore cartilages; $m 2 b$, absent; $m 2 c$, tinny transversal muscle auxiliary of $m 2 ; m 3$, long and cylindrical muscle forming outer wall of odontophore, with transverse fibers; $m 4$, pairs of thin, strong radular dorsal tensor muscles covering almost entire surface of posterior portion of odontophore cartilages, originating outside edges of cartilage and inserting into subradular membrane; $m 5$, pair of thin auxiliary dorsal tensor muscles of radula, originating inside edges of cartilage, adjacent to $\mathrm{m} 4$ insertion; $m 6$, horizontal muscle, thin, connecting ventral edges of cartilages, running $2 / 3$ of their length; $m 8$, pair 
of elliptical muscles, $\sim 1 / 5$ of total length of odontophore, originating at anterior end of odontophore cartilages, running along ventral surface of odontophore, inserting on anterior ventral surface of cartilages; $m 11$, pair of ventral tensor muscles of radula, about $1 / 3$ of total odontophore length, originating at ventral-posterior end of cartilages, crossing ventrally entire odontophore, inserting into ventral posterior surface of radula. Additional odontophore structures: $b r$, subradular membrane, thin, strong and translucent, along entire length of radular ribbon, covering inner surface of odontophore cartilages; $o c$, odontophore cartilages, about $2 \mathrm{x}$ long as wide, inner ventral surface concave, $\sim 1 / 7$ of anterior end fused with each other.

Radular teeth (Fig. 287). Rachidian tooth wide, comb-like, occupying about half of radular width; base curved, length $\sim 3 \times$ its width; $\sim 11$ triangular, sharp pointed cusps of similar size, except for some diminishment towards the side; lateral tooth hook-like, with two cusps, base broad (equivalent to rachidian base width), obliquely disposed; main lateral cusp widely curved inwards, about as long as base; secondary cusp approximately $1 / 2$ size of main lateral cusp with 1 small cusp, radula ribbon equal between males and females; jaws absent.

Genital system. Male (Fig. 293). Vas deferens narrow, simple, sinuous, running along ventral surface of kidney up to pallial cavity. Prostate totally closed (tubular), running thought right mantle edge, at $\sim 1 / 3$ of total pallial cavity length. Vas deferens anterior to prostate, straight, running immersed into integument of dorsum, next to mantle border and penis base. Penis slender, length $~ 2 / 4$ of total head-foot length, cilindrical; base curved, apical region distinguished by a dilation. Penial duct straight, running through center of penis, closed (tubular). Penial aperture distal, small.

Female (Figs. 290, 294, 295). Visceral oviduct thin, narrow, straight, running along dorsal surface of kidney in first whorl of visceral mass, located in front of pallial cavity. Pallial oviduct large, protruding into kidney, occupying $~ 1 / 2$ of length of pallial cavity and $1 / 5$ of its width. Albumen gland posterior, whitish, thick-walled, occupying $\sim 1 / 5$ of pallial oviduct. Capsule gland $\sim 4 / 5$ of oviduct, elongated, orange, thick-walled. Vaginal atrium narrow, tubular, occupying 1/5 of oviduct; walls thick, muscular, female genital pore small, simple. Bursa copulatrix absent. Cement gland absent.

Central nervous system (Fig. 299). Similar to all Phrontis. 
Shell measurements (length $x$ width in mm): MZSP 91094; 4 ㅇ 6.5 x 4.2; 6.6 x 4.4; $5.4 \times 4.1 ; 5.0 \times 3.9 ; 2 \lesssim 6.2 \times 4.1 ; 5.8 \times 6.2$.

Distribution: Brazil, Espirito Santo.

Habitat: Sand bottoms, intertidal.

Material examined: MZSP 91094 4ํ 20̂, Brazil: Espirito Santo; Guarapari (J. Coltro col. 2009). 


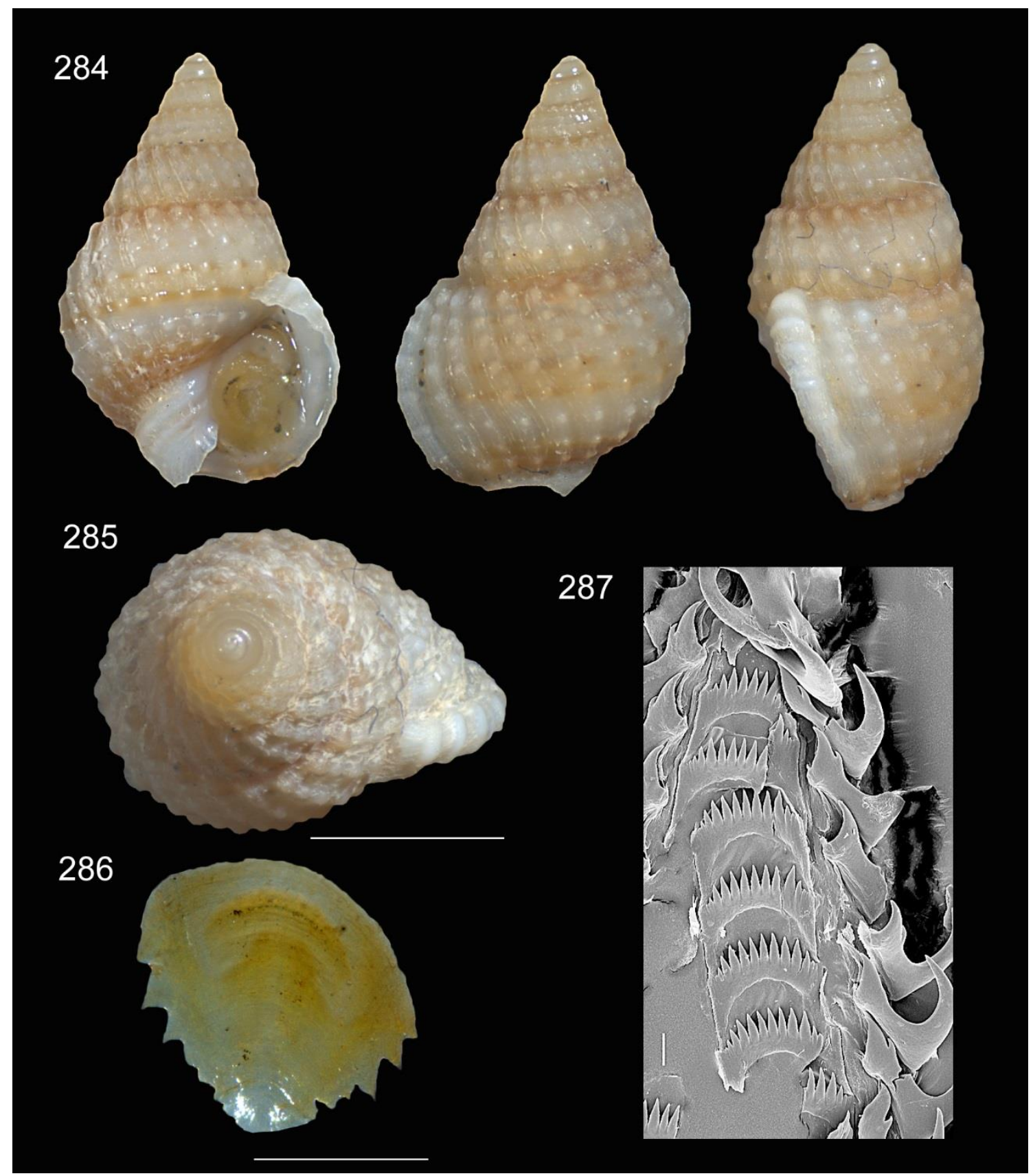

Figs. 284-287. Phrontis sp. 3: MZSP 91094 我, shell, operculum and radula; Figs 284: Adult specimen, Shell apertural, dorsal view and lateral view (L 6,5 mm); Fig. 285: shell apical view, scale $=2$ mm; Fig. 286: Operculum dorsal view, scale $=2$ mm; Fig. 287; SEM of radula: Panoramic view of middle portion, scale $=30 \mu \mathrm{m}$. 

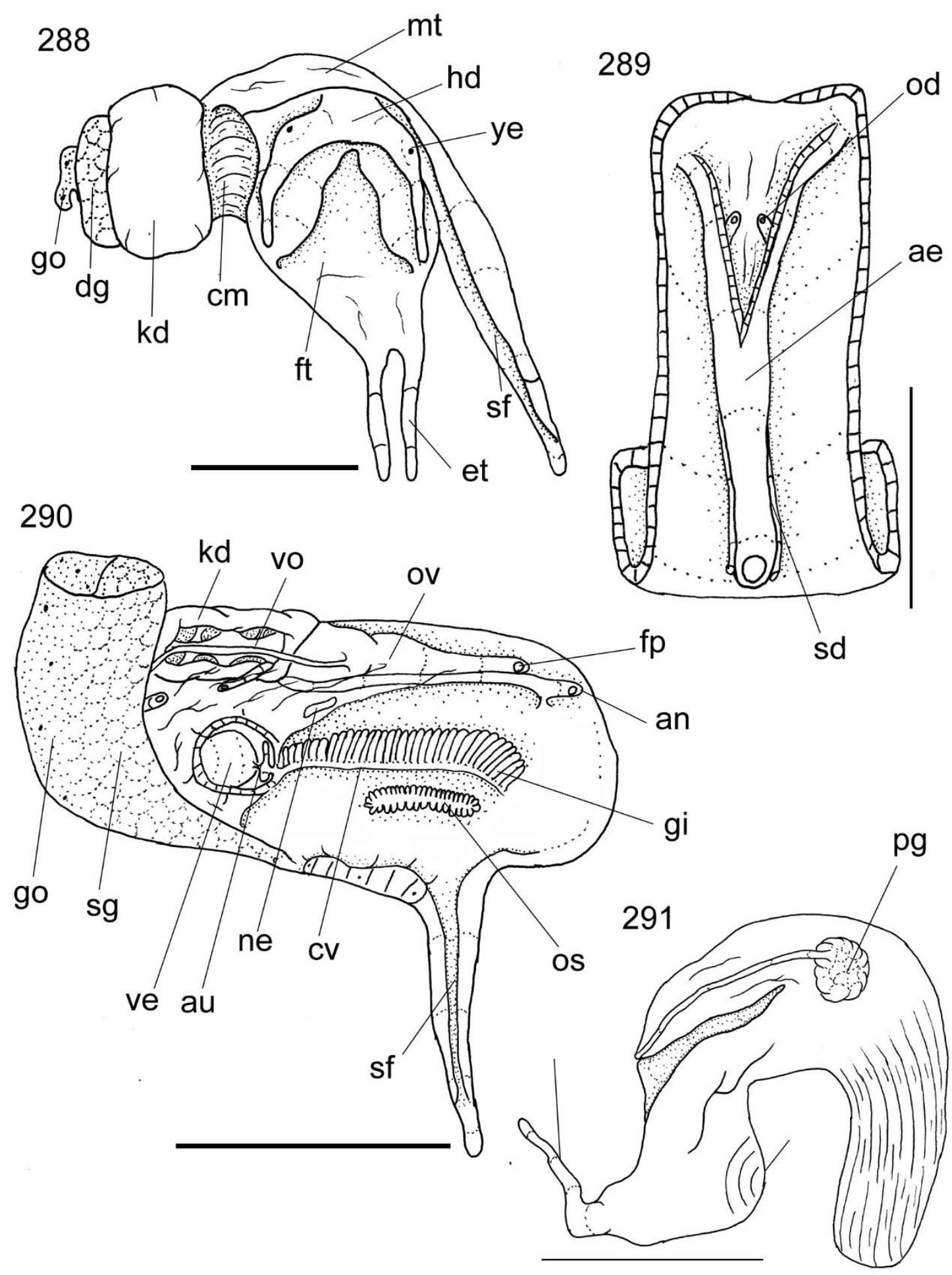

Figs. 288-291. Phrontis sp. 3: Details of anatomy, Fig. 288: complete specimen extracted from shell (operculum removed), anterior-right view; Fig. 289: Proboscis and anterior esophagus opened longitudinally, showing salivary ducts and their apertures; Fig. 290: Pallial cavity roof, ventral view; Fig. 291: Foot of female, sagittal section. Scales $=2 \mathrm{~mm}$. 

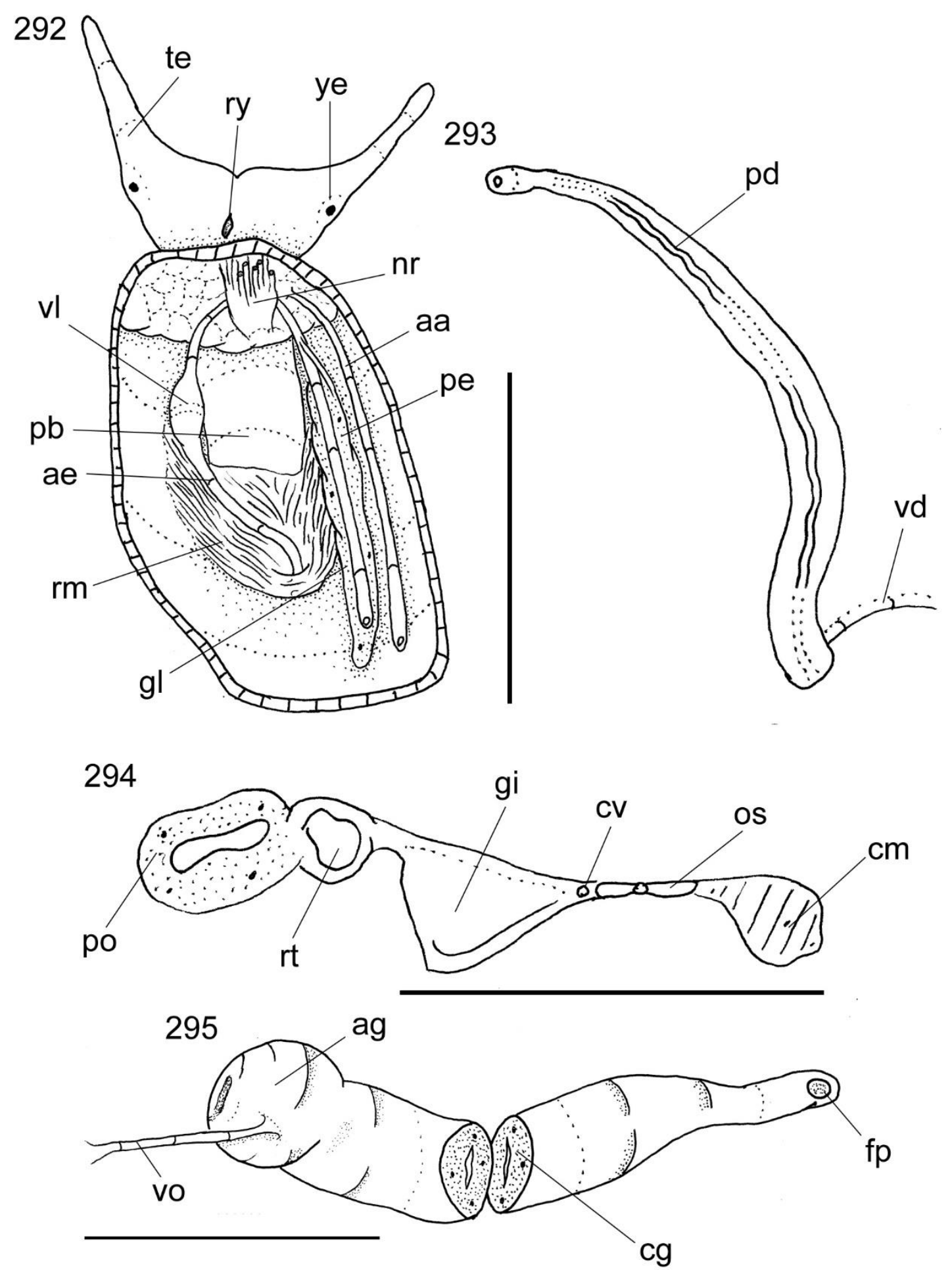

Figs. 292-295. Phrontis sp. 3: Details of anatomy, Fig. 292: Head and haemocoel, ventral view, foot and columellar muscle removed; Fig. 293: Penis, lateral left view; Fig. 294: Pallial cavity roof, transverse section at middle level of osphradium; Fig. 295: Pallial oviduct, right lateral view. Scales $=2 \mathrm{~mm}$. 

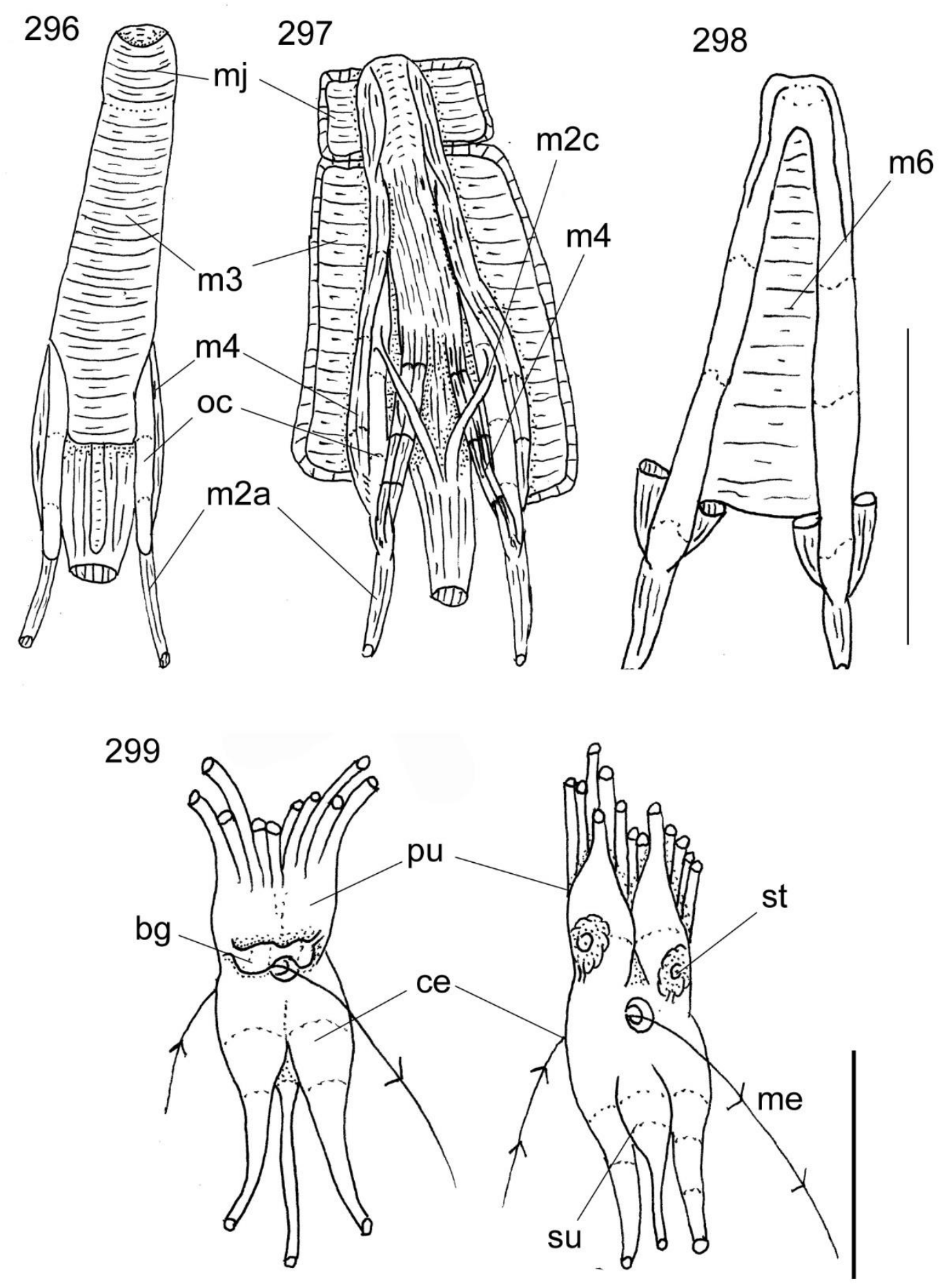

Figs. 296-299. Phrontis sp. 3: Details of anatomy, Fig. 296: Odontophore, dorsal view, superficial layers showed; Fig. 297: Odontophore, dorsal view, superficial muscles dissected; Fig. 298: Odontophore cartilages, associated muscles shown; Fig. 299: Nerve ring, dorsal and ventral view. Scales $=2 \mathrm{~mm}$. 


\section{Phrontis sp. 4}

Figs. 300-317.

Shell (Figs. 300, 301). Ovate, about twice long as wide, with 5 convex whorls; color, light yellow and white, with cream and light brown bands near the sutures. Protoconch big, smooth, cream, with three whorls; transition to teleoconch hardly indicated by a depression and by the difference of sculpturing. Teleoconch sculpture composed of light orange axial ribs along entire surface and white spiral nodules near the sutures, spire angle $\sim 50^{\circ}$, shoulder absent. Aperture prosocline, rounded, posteriorly acuminate, ca. 1/3 of shell length; color white; outer lip thick, palatal wall lirated; parietal rib weakly present; Parietal shield restrict to internal lip; Anal notch weakly marked. Siphonal canal short, strong, deep, narrow ( 1/3 of aperture length) and dorsally recurved.

Head-foot (Figs. 304, 309). Head not protruded; tentacles separated from each other, elongated and narrow; eyes not pedunculated, located in medium region of tentacles. Foot small, occupying half of body whorl (retracted), flat, bearing a pair of medium metapodial tentacles; pedal gland located closed to the edge of foot, forming a groove, extending to dorsum of foot (propodium). Opercular pad occupying $~ 1 / 8$ of dorsal area of foot, oval. Penis originated in right lateral region, posterior to cephalic base, at level of mantle edge. Columellar muscle small and broad, 1/2 whorl long. Haemocoel long and narrow, extending dorsally along center of foot and columellar muscle, $2 \mathrm{x}$ as long as wide.

Operculum (Fig. 302). Small, ovate, horny, amber, semi-translucent; occupying about $70 \%$ of aperture. Nucleus terminal, inferior. Outer surface with normal concentric growth lines, forming undulations. Scar elliptical, occupying about $2 / 3$ of inner surface, located close to edge of foot; expansions in the form of spines on both sides, left and right.

Mantle organs (Figs. 306, 307). Mantle cavity covering 1 1/2 whorl. Siphon long and thin width $1 / 4$ of mantle cavity width, length $\sim 1 / 2$ of mantle cavity length. Right and left base of siphon low, ending directly in the mantle. Osphradium large, narrow, elliptical, length $1 / 3$ of pallial cavity length, width $~ 1 / 6$ of its width. Osphradial filaments short, broad, projected from mantle. Ctenidial vein (efferent branchial vessel) uniformly narrow along its length. Gill long and narrow, rectangular, occupying $~ 2 / 3$ of length and $1 / 5$ of width of pallial cavity. Anterior end of gill rounded, ending gradually, inserted directly into pallial cavity. Anterior end of gill tapered. Gill filaments low and triangular. Right side of pallial cavity almost entirely filled by gonoducts. Rectum long and thin, 
occupying all pallial cavity lenght Anus siphoned, distance between anus and mantle border $\sim 1 / 5$

of total pallial cavity length. Anal gland absent.

Visceral mass (Fig. 306). Similar to all species included in genus Phrontis.

Circulatory and excretory systems (Figs. 306, 307). Reno-pericardial region occupying 1 whorl, adjacent to mantle cavity; square shaped. Pericardium large occupying $1 / 3$ of reno-pericardial region, posterior to gill; situated on left anterior margin of visceral mass. Auricle muscular. Ventricle two times as large as auricle, with common aorta in left posterior margin. Kidney occupying $1 / 3$ of pallial cavity length, renal lobe single, divided into chambers. Nephrostome small, transversal slit, located in anterior region of membrane between kidney and pallial cavity.

Digestive system (Figs. 305, 308, 310-314). Mouth, proboscis, salivary gland and salivary ducts similar to anterior species. Valve of Leiblein small, about 1/6 of proboscis volume, located in medium esophagus anterior to nervous ring, diameter about $1 \mathrm{x}$ of the medium esophagus, anterior region with transverse white band bearing long cilia, middle and posterior regions white, corresponding to inner gland that occupies most of inner surface. Gland of Leiblein slender, $\sim 2 \mathrm{x}$ longer than middle esophagus, becoming narrower toward posterior, duct of Gland of Leiblein, long and narrow. Accessory salivary glands absent. Anterior esophagus same as Phrontis alba.

Odontophore and buccal mass muscles: $m j$, thick of perioral muscles connected on both sides, dorsal and ventral, surrounding odontophore cartilages short, about 1/4 of odontophore length,; $m 1$, jugal muscles, several tinny and thin fibers which connected odontophore in proboscis wall; $m 2$, Strong protractor muscles of buccal mass, originating on inner surface of proboscis, running along entire odontophore, inserting in anterior region of odontophore cartilages; $m 2 a$, absent; $m 2 b$, absent; $m 2 c$, absent; $m 3$, long and cylindrical muscle forming outer wall of odontophore, with transverse fibers; $m 4$, pairs of thin, strong radular dorsal tensor muscles covering almost entire surface of posterior portion of odontophore cartilages, originating outside edges of cartilage and inserting into subradular membrane; $m 5$, pair of thin auxiliary dorsal tensor muscles of radula, originating inside edges of cartilage, adjacent to $m 4$ insertion; $m 6-m 8$, similar to previous. Additional odontophore structures: $b r$, subradular membrane, thin, strong and translucent, along entire length of radular ribbon, covering inner surface of odontophore cartilages; $o c$, odontophore cartilages, about $2 \mathrm{x}$ long as wide, inner ventral surface concave, $\sim 1 / 5$ of anterior end fused with each other. 
Radular teeth (Fig. 303). Same pattern of all Phrontis previous species.

Genital system. Male (Fig. 315). Vas deferens narrow, simple, sinuous, running along ventral surface of kidney up to pallial cavity. Prostate totally closed (tubular), running thought right mantle edge, at $\sim 1 / 3$ of total pallial cavity length. Vas deferens anterior to prostate, straight, running immersed into integument of dorsum, next to mantle border and penis base. Penis slender, length $\sim 2 / 3$ of total head-foot length, cilindrical; base curved, apical region distinguished by a dilation. Penial duct straight, running through center of penis, closed (tubular). Penial aperture distal, small.

Female (Figs. 306, 307, 317). Visceral oviduct thin, narrow, straight, running along dorsal surface of kidney in first whorl of visceral mass, located in front of pallial cavity. Pallial oviduct large, protruding into kidney, occupying $~ 1 / 2$ of length of pallial cavity and $1 / 5$ of its width. Albumen gland posterior, whitish, thick-walled, occupying $\sim 1 / 5$ of pallial oviduct. Capsule gland $\sim 4 / 5$ of oviduct, elongated, orange, thick-walled. Vaginal atrium narrow, tubular, occupying 1/5 of oviduct; walls thick, muscular, female genital pore broad. Bursa copulatrix absent. Cement gland absent.

Central nervous system (Fig. 316). Similar to previous species included in genus Phrontis.

Central nervous system (Fig. 316). Similar to previous species included in genus Phrontis.

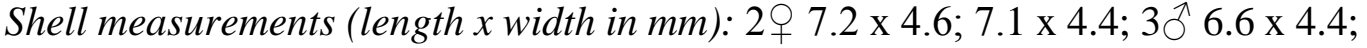
$5.9 \times 4.2 ; 6.8 \times 4.6$.

Distribution: Brazil, Espirito Santo, Trindade Island. Secom Beach.

Habitat: Sand bottoms, intertidal.

Material examined: MZSP 1155582 2 $3 \hat{\sigma}$, Brazil: Espirito Santo; Trindade

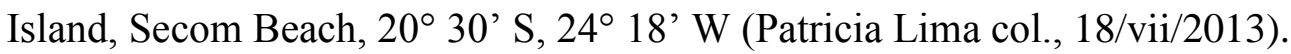




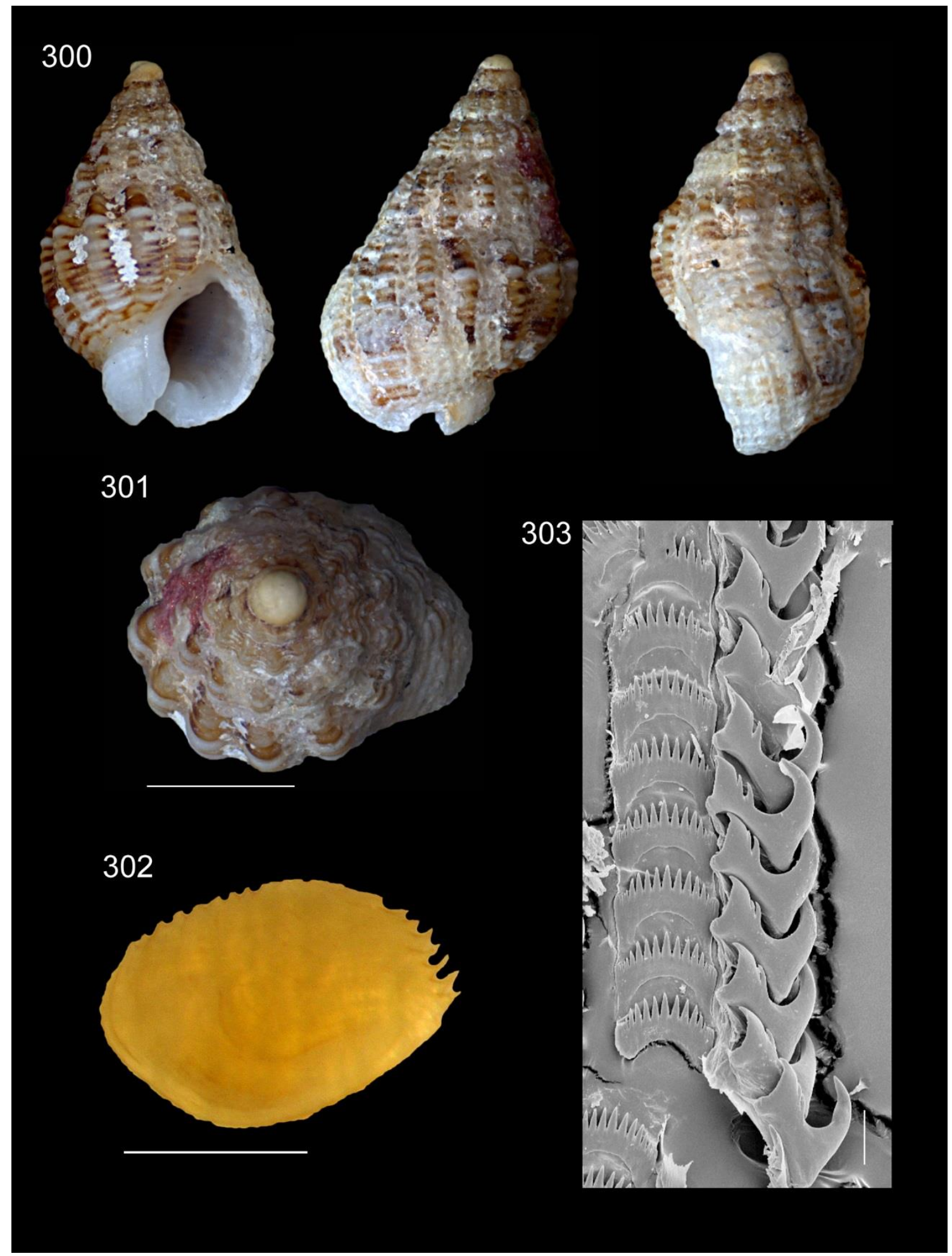

Figs. 300-303. Phrontis sp. 4: MZSP 115558 9 , shell, operculum and radula; Figs 300: Adult specimen, shell apertural, dorsal and lateral view (L 7,2 mm); Fig. 301: shell apical view; scale = $2 \mathrm{~mm}$; Fig. 302: Operculum dorsal view, scale $=2 \mathrm{~mm}$; Fig. 303; SEM of radula: Panoramic view of middle portion, scale $=30 \mu \mathrm{m}$. 

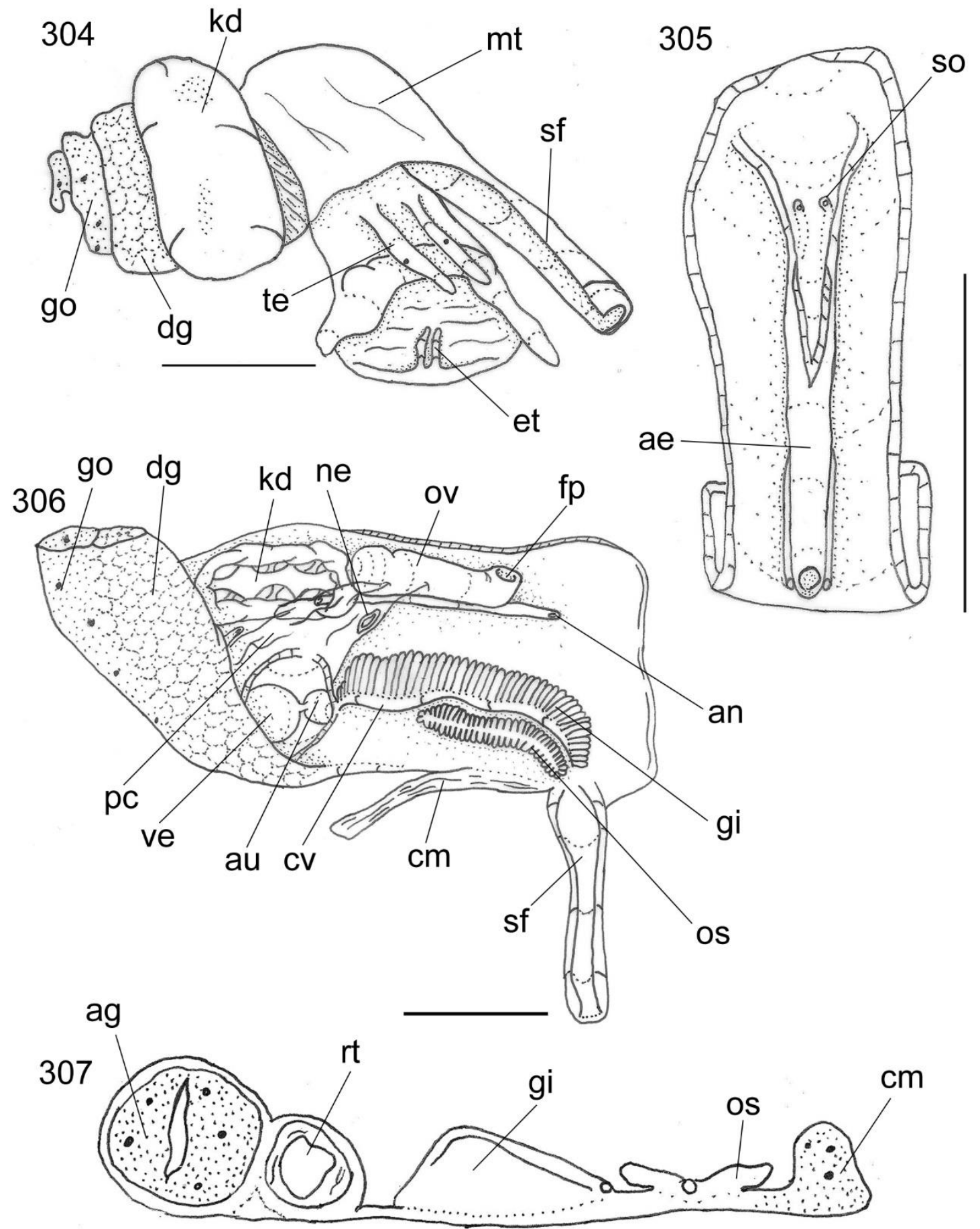

Figs. 304-307. Phrontis sp. 4: Details of anatomy, Fig. 304: complete specimen extracted from shell (operculum removed), anterior-right view; Fig. 305: Proboscis and anterior esophagus opened longitudinally, showing salivary ducts and their apertures; Fig. 306: Pallial cavity roof, ventral view; Fig. 307: Pallial cavity roof, transverse section at middle level of osphradium. Scales $=2 \mathrm{~mm}$. 

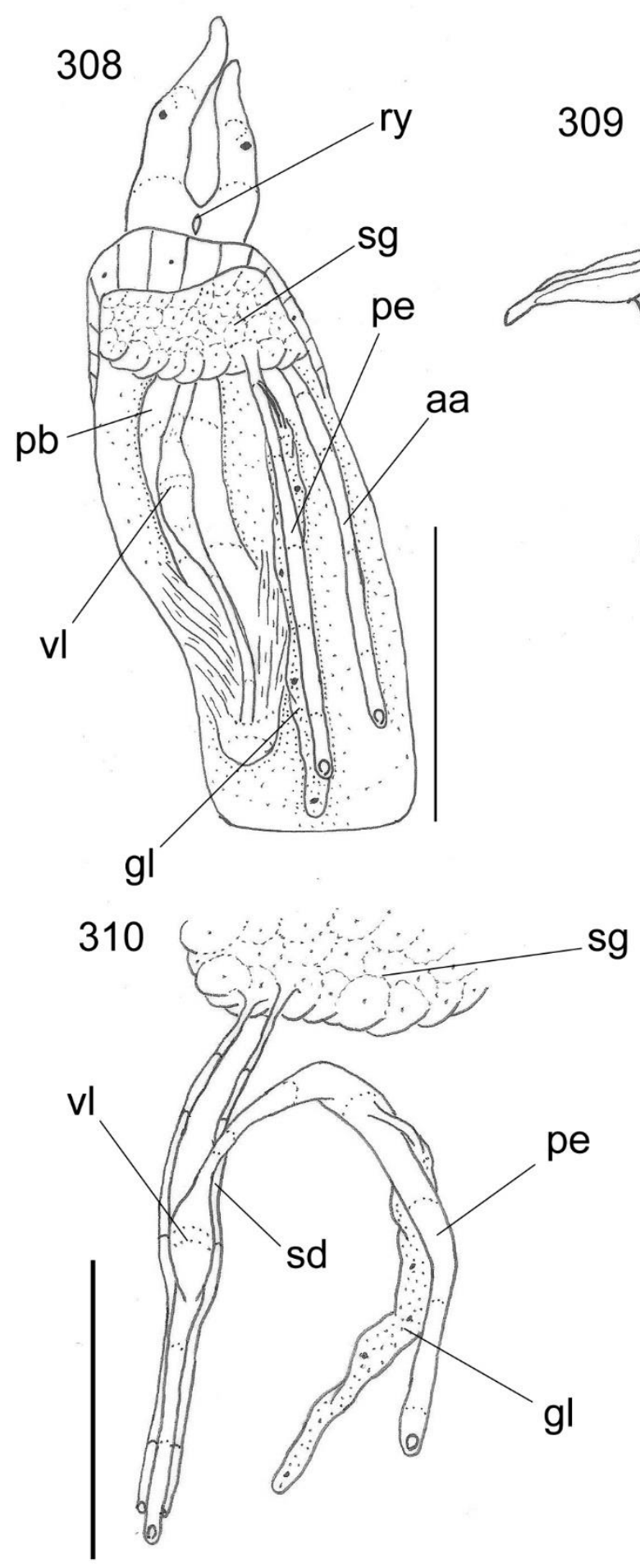
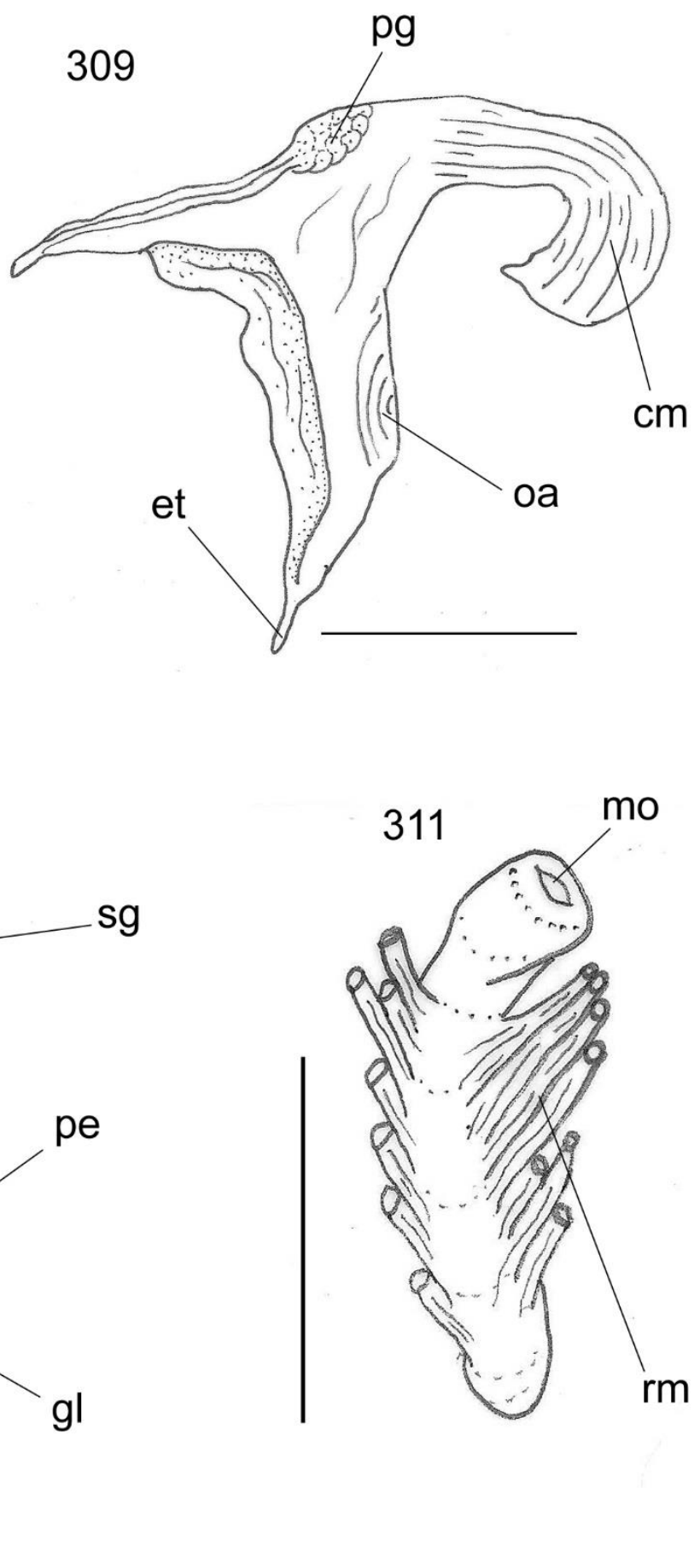

Figs. 308-311. Phrontis sp. 4: Details of anatomy, Fig. 308: Head and haemocoel, ventral view, foot and columellar muscle removed; Fig. 309: Foot of female, sagittal section; Fig. 310: Detail of fore and midgut, associated structures also shown; Fig. 311: Proboscis ventral view, retractor muscles also shown. Scales = $2 \mathrm{~mm}$. 


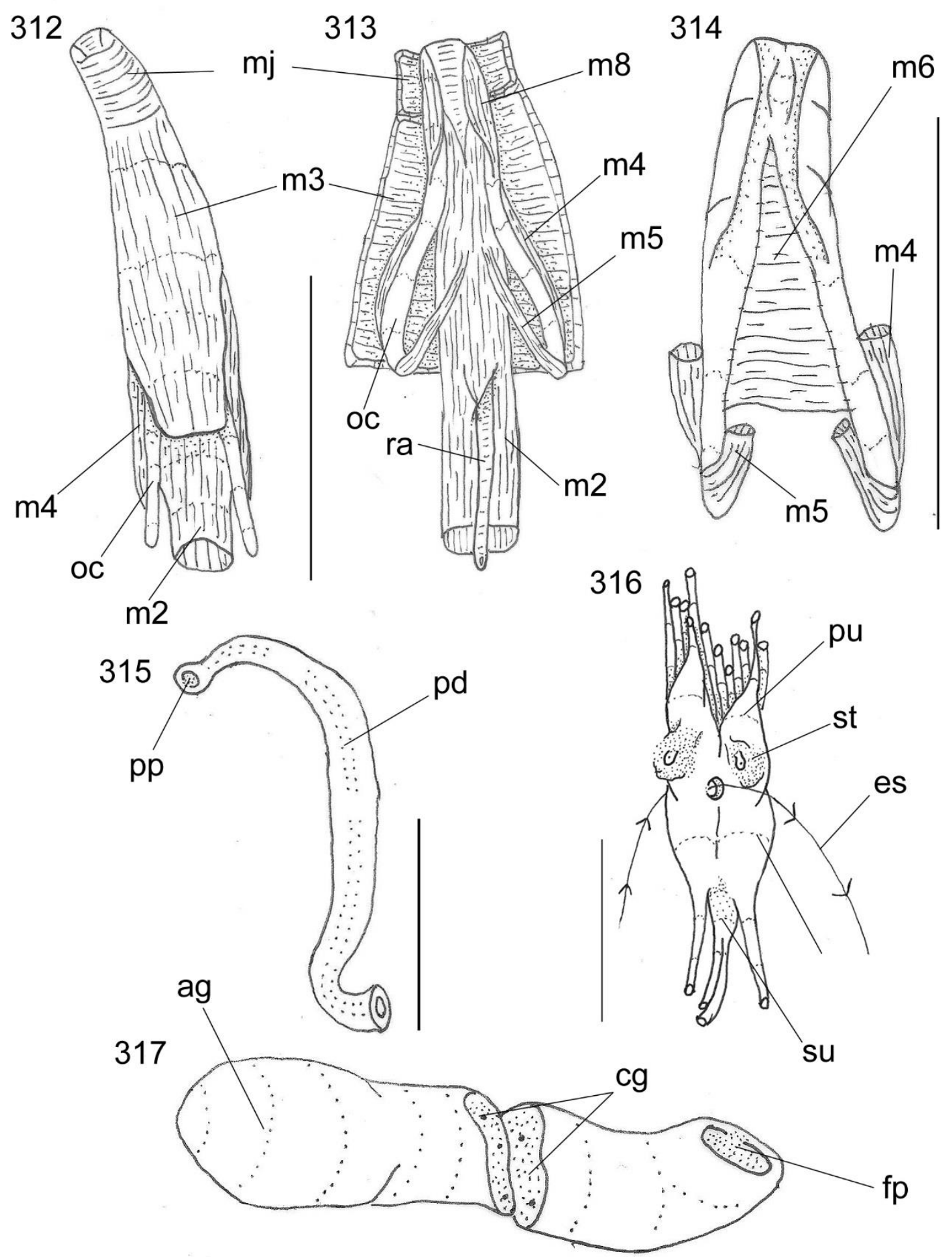

Figs 312-317. Phrontis sp. 4: Details of anatomy, Fig. 312: Odontophore, dorsal view, superficial layers showed; Fig. 313: Odontophore, dorsal view, superficial muscles dissected; Fig. 314: Odontophore cartilages, associated muscles shown, Fig. 315: Penis, lateral left view; Fig. 316: Nerve ring, dorsal view; Fig. 317: Pallial oviduct, right lateral view. Scales $=2 \mathrm{~mm}$. 


\section{Apresentação e Discussão dos Caracteres}

A descrição de cada caracter começa com uma frase ou palavra título descritiva resumida seguida pela apresentação das condições plesiomórficas e apomórficas; também é incluído os índices CI e RI (indice de consistência e retenção respectivamente), o número de passos (L) e a otimização escolhida (Acctran ou Deltran). Os caracteres informativos utilizados para resolver a filogenia de Nassarinae ilustram a ampla variedade de características morfológicas dos táxons envolvidos na análise. 34 caracteres são neomórficos e 69 são transformacionais. Os estados de carácter são indicados com números: 0, para a condição plesiomórfica; 1-4, para a condição apomórfica. A lista de caracteres utilizados na análise está dividida em: concha, opérculo, massa cefalopediosa, cavidade palial, sistemas digestivo, excretório, reprodutor e nervoso.

\subsection{Concha}

1. Forma: $0=$ Turbiforme; $1=$ Domo ( $P$. pusio, B. undatum, B. granulosa, B. laevisssima, D. miran, B. gradatus, B. moniliferum); 2= Cônica (V. cassiforme, $R$. morissoni); $3=$ Fusiforme (P. morio, $P$. tupiniquim, $P$. aurantiaca, . larvigata, $P$. ogum, F. frenguelli, L. nassa, T. roboreus); 4= Oval (E. unicincctus, D. abbreviata, Cyclope sp., H. pulla, H. luteostoma, H. reticulata, H. corticata, H. olivacea, Phrontis sp. 3, Phrontis sp. 1, Phrontis sp. 2, Phrontis sp. 4, Phrontis alba, P. Incrassata, N. vibex, $N$. polygonatus, $N$. arcularia, $N$. scabriusculus, $N$. coronatus $)(\mathrm{IC}=66, \mathrm{RI}=85, \mathrm{~L}=$ 6)(Acctran).

Apesar da ordem Buccinoidea apresentar uma grande variedade na forma da concha, esse caráter se mostrou bastante informativo para esta análise como indicado pelos índices. Esse carácter sofreu 6 transformações com duas convergências, para o estado 1 (forma de domo) no nó 34 e para o estado 3 (Fusiforme) no nó 1 e 9. Todos os estados embasam algum nó dessa análise.

2. Espira: $0=\mathrm{Alta} ; 1=$ Baixa (R. morissoni, V. cassiforme, Cyclope sp.) $(\mathrm{IC}=33$, $\mathrm{RI}=0, \mathrm{~L}=3$ ) (deltran).

Como o estado 0 (espira alta) está presente na maioria dos animais da análise esse caráter se mostrou pouco informativo, nenhum nó foi embasado. Porém é uma característica muito marcante para a concha e como existem algumas dúvidas no nível especifico, foi utilizado, mesmo tendo modificado apenas três vezes como autapomorfias de ramos terminais. 
3. Periostraco piloso: $0=$ ausente, $1=$ presente $(T$. laevigata, $V$. cassiforme, $P$. tupiniquim, $P$. morio) $(\mathrm{IC}=50, \mathrm{RI}=66, \mathrm{~L}=2)$.

Esse caráter ajuda a organizar os grupos externos, já que sofreu duas modificações independentes para o estado 1 em táxons incluídos no grupo externo, sendo que em uma delas é sinapomorfia do clado 8.

4. Superficie da concha: $0=$ fosca, $1=$ lustrosa $(R$. morissoni $)(\mathrm{IC}=-, \mathrm{RI}=-, \mathrm{L}=-)$

A presença de uma superfície da concha lustrosa é comumente encontrada em táxons mais basais dentro da superordem Caenogastropoda, por exemplo, Cypraeoidea e Pseudolivoidea, por isso esse caráter resultou como sendo uma autapomorfia da espécie $R$. morissoni. No entanto, sua presença foi fundamental para a organização dos táxons presentes no grupo externo.

5. Sutura: $0=$ rasa, $1=$ profunda $(P$. aurantiaca, $F$. frenguelli, $P$. morio, $P$. tupiniquim, T, roboreus, B gradatum, B. moniliferus, Phrontis sp. 1, P. incrasata, Phrontis sp. 2, Phrontis sp. 3, Phrontis sp. 4. Phrontis alba) $(\mathrm{IC}=11, \mathrm{RI}=55, \mathrm{~L}=9)$ (acctran).

Apesar da concha ser indubitavelmente a estrutura mais analisada nos estudos sobre moluscos, por ser a parte mais durável do animal, em espécies muito próximas fica difícil inferir alguma taxonomia baseando-se apenas em caracteres conquiliológicos, devido ao seu grau de variação. A sutura, como faz parte da estruturação da concha, sofre essa variação e, por conta disso, o caráter se mostrou diluído por toda a topologia aparecendo como sinapomorfias no estado 1 (presente) para os nós 5, 9, 10, 36 e como reversão para o estado 0 (ausente) nos nós 12, 20, 28.

6. Tamanho do calo parietal: 0 : Restrito a abertura, $1=$ excedendo $\sim 20 \%$ da abertura (T. laevigata, L. nassa, F. frenguelli, V. cassiforme, Phrontis sp. 2, Phrontis sp. 1, Phrontis sp. 4, Phrontis alba), 2= excedendo $\sim 50 \%$ da abertura (N. scabriusculus, N., N. vibex, $N$. polygonatus, $H$. pulla, H. luteostoma) (IC: 25, RI: 62, L: 8).

A maioria dos Buccinoidea apresentam calo parietal resultante do crescimento da borda do lábio interno da abertura (Vermeij, 1992). Nos nassarídeos essa característica é mais acentuada, pois hipertrofiaram essa estrutura, no gênero Nassarius, estrito senso (nó 24), o crescimento desse calo é tão acentuado que chega a cobrir $~ 50 \%$ da volta corporal. Nesta análise o caráter sofreu 8 transformações, como convergências para o estado 1 nos nós 18 e 31 e como sinapormofia no estado 2 para o nó 24.

7. Dente parietal: $0=$ ausente, $1=$ presente $(P$. pusio, $P$. Incrassata, Phrontis $s p$. 1, Phrontis sp. 2, Phrontis sp. 4, Phrontis alba) (IC: 16, RI: 66, L: 6). 
A presença de um dente parietal, na região anterior da abertura da concha, delimitando o canal anal surge a partir do nó 17, em Buccinidae e Nassariidae, podendo ser considerado homologo entre essas duas famílias. $\mathrm{O}$ estado 1 aparece como sinapomorfia nos nós 17, 24, 29 passando por uma reversão no nó 33.

8. Desenvolvimento do dente parietal: $0=$ pouco desenvolvido, $1=$ muito desenvolvido ( $P$. pusio, Hinia, Nassarius, H. pulla, H. corticata, H. luteostoma, Demoulia sp.) (IC: 25, RI: 0: L: 4).

Caráter não polarizado devido à ausência da estrutura na espécie B. atafona, $\mathrm{O}$ estado 1 surge como sinapomorfia do gênero Hinia (nó 29) com reversão nas espécies Phrontis sp. 2 e Phrontis sp. 4, o que auxiliou na separação entre as espécies do complexo "Nassarius albus".

9. Ombro na abertura da concha: $0=$ ausente, $1=$ presente (Fasciolariidae, $V$. cassiforme, P. morio, P. tupiniquim) (IC: 33, RI: 60, L=3).

O caráter foi constituído baseando-se na presença da estrutura em alguma fase do crescimento ou em alguma variação presente em um exemplar. O estado 1 aparece como sinapormofia de Fasciolariidae (nó 3) convergindo no nó 8 e serviu para o arranjo do grupo externo.

10. Engrossamento da borda do lábio externo: $0=$ ausente, $1=$ presente (Buccinidae, Nassariidae) (IC: 20, RI: 69, L: 5).

Caráter que surge, novamente, como sinapomorfia do nó que une nassarídeos e bucinídeos (11) e se mantém presente (estado 1) até o nó 28 onde sofre uma reversão para o estado 0, (ausente), no grupo de nassarídeos que, de fato, apresentam uma concha mais delicada e fogem um pouco da robustez tradicional das conchas de nassarídeos, esse grupo é tradicionalmente chamado de "Bullia group" sugerido por Brown (1982) e representado nesta análise pelas espécies, D. miran, B. laevissima, B. granulosa e Demoulia sp.

11. Esculturação da concha: $0=$ ausente, $1=$ nódulos regulares $($ Buccinoidea $), 2=$ nódulos irregulares (V. cassiforme, B. undatum) (IC: 20, RI: 27, L: 10) (acctran).

A presença de nódulos esculturais regulares está presente como sinapomorfia em todos Buccinoidea a partir do nó 2, mas sofre reversão para o estado 0 (ausente), como autapomorfia nas espécies $R$. morrisoni, $P$. pusio, B. gradatus, Cyclope sp., $N$. coronatus e H. olivacea. Essa reversão ainda se mostrou uma sinapomorfia do nó 34, "Bullia group". A transformação para o estado 2 (nódulos irregulares) também surgiu independentemente como autapomorfia de V. cassiforme e B. undatum. Mesmo com um, 
relativo, alto valor de transformações o caráter se mostrou bastante interessante quanto ao surgimento de escultura na concha dentro da superfamília Buccinoidea.

12. Superfície interna do lábio externo: $0=$ lisa, $1=$ esculturada (Fasciolariidae, $V$. cassiforme, P. morio, P. tupiniquim, T. roboreus, P. pusio, Phrontis, N. poligonatus, N. coronatus, Hebra, "Bullia group") (IC: 10, RI: 40, L: 10) (acctran).

É bastante comum gastrópodes apresentarem uma escultura na superfície interna do lábio em forma de liras ou até mesmo pequenos nódulos na borda da abertura. O caráter sofreu a primeira transformação no nó 2 e posteriormente surgiu independentemente para o nó 17 e 27, mas manteve a condição plesiomórfica nos nós 24 e 34.

13. Incisura parasifonal: $0=$ ausente, $1=$ presente (T. laevigata, P. ogum, V. cassiforme, B. gradatus, B. moniliferum) (IC: 25, RI: 25, L: 4).

Esta estrutura é formada pelo espessamento da superfície interna do lado direito do canal sifonal formando uma espécie de furo quando esse espessamento se encontra com a superfície externa do sifão. $\mathrm{O}$ estado 1 ocorre como convergência autapomórfica em 3 terminais do grupo externo e também como convergência, mas sinapomórfica, do clado mais basal de Nassariidae (nó 14), os demais nassarídeos mantiveram o estado mais plesiomórfico.

14. Canal sifonal projetado: $0=$ ausente, $1=$ presente $($ T. laevigata, Fasciolariidae, V. cassiforme, P. morio, P. tupiniquim, T. roboreus, Buccnidae, Nassariidae) (IC: 25, RI: 25, L: 4).

A maioria dos Caenogastropoda apresenta um canal sifonal inalante, e aparentemente, apenas desenvolvido por eles (Simone, 2011), a projeção ou alongamento desse canal é mais evidente dentro da ordem Neogastropoda, em fasciolariídeos, buccinídeos e nassarídeos (Fretter \& Graham, 1962), como retratado na topologia. No presente estudo apenas Cyclope sp. e o gênero Bullia encurtaram o tamanho do canal sifonal dentro da família Nassariidae, revertendo assim o caráter para o estado 0 .

15. Concha tamanho do canal sifonal: $0=$ até $1 / 2$ da abertura da concha, $1=$ maior que a $1 / 2$ da abertura da concha $(P$. ogum, $P$. aurantiaca, $F$. frenguelli, $V$. cassiforme, $P$ tupiniquim, P. morio $)(\mathrm{CI}=50, \mathrm{RI}=80, \mathrm{~L}=2)($ deltran$)$.

Corroborando com o caráter anterior, a presença do canal sifonal longo, maior que a 1/2 da abertura da concha (estado 1) aparece como sinapomorfia de um subgrupo dentro de Fasciolariidae (nó 3) e do nó 8, clado que une V. cassiforme, P. tupiniquim e P. morio. 
16. Canal anal: $0=$ ausente, $1=$ presente (T. laevigata, $P$. aurantiaca, $V$. cassiforme, P. morio, P. tupiniquim, T. roboreus, B. undatum, Buccinanops, Phrontis sp. 2, Phrontis sp. 4, nó 22) (IC:9, RI: 23, L: 11) (deltran).

A presença do canal anal se mostrou independente da presença do dente parietal (caráter 7), certamente as espécies que possuem tal estrutura mostram um canal anal muito mais acentuado. $\mathrm{O}$ caráter se mostrou pulverizado, com ambos estados ocorrendo no grupo externo e interno, mas neste também se revelou como sinapormorfia dos nós 14 e 22.

17. Plicas columelares: $0=$ ausente, $1=$ presente $(T$. laevigata, Fasciolariidae, $V$. cassiforme, $R$. morrisoni, T. roboreus, P. pusio) (IC: 20, RI: 55, L: 5) (acctran).

Como sugerido por diversos autores, a presença de plicas columelares (estado 1) aparece em diversas famílias da ordem Neogastropoda, por exemplo, Fasciolariidae, Turbinellidae e Buccinidae. (e.g., Ponder, 1974, Simone, 2011, Kantor, 1996), a partir do nó 13 que agrupa todos os nassarídeos o caráter sofre uma reversão para o estado 0 .

18. Posição das plicas quando presentes: $0=$ base do sifão, $1=$ região média do lábio interno (T. laevigata, L. nassa, P. ogum, F. frenguelli, $R$. morrisoni, V. cassiforme) (IC: 50, RI: 66, L: 2).

Caráter vinvulado ao caráter anterior, não sendo, portanto, codificado para os que não possuem pregas. Porém, resumiu-se nas espécies contidas no grupo externo. A presença de plicas na região média do lábio interno se mostrou como uma importante sinapomorfia da superfamília Buccinoidea (nó 2).

19. Forma da abertura: $0=$ elíptica, $1=$ quadrada ( $L$. nassa, $P$. tupiniquim) (IC: 50, RI: 0, L: 2).

Caráter pouco informativo para o grupo interno, já que em sua grande maioria o elenco de espécies selecionado mantém o estado plesiomórfico, de forma elíptica da abertura. O caráter foi mantido porque, em associação a outros caráteres, auxiliou na taxonomia especifica do gênero Pugilina. 
20. Número de voltas da protoconcha: $0=$ duas, $1=$ duas e meia (P. tupiniquim, $P$. pusio, B. undatum, Phrontis, N. coronatus, Hinia corticata, Bullia, E. unicinctus, N. paucicostatus), 2= três (Buccinanops, N. vibex, N. polygonatus) (IC: 22, RI: 61, L: 9).

Como todas as espécies selecionadas para a análise apresentaram protoconcha multispiral, ou seja, possuem mais que uma volta e meia de protoconcha, esse caráter teve de ser esmiuçado para ilustrar os 3 estados encontrados e a metodologia de contagem de voltas de Diver (1931), ainda se mostrou eficiente para tal.

A transformação para o estado 1 (duas voltas e meia) se deu através de 3 convergências sinapomórficas entre os nós 11, 35, 37, para o estado 2 (três voltas), outra convergência sinapomorfica entre os nós 14 e 26 . O caráter ainda sofre uma reversão sinapomorfica no nó 22, todas transformações suportam algum clado da análise.

\subsection{Massa cefalopediosa}

21. Estrutura muscular corporal: $0=$ resistente, $1=$ frágil $(R$. morrisoni, $T$. roboreus, Phrontis, Cyclope sp., Hinia corticata, Demoulia abreviata) (IC: 16, RI: 54, L: $6)$.

Foi notado que, independentemente do estado da conservação dos espécimes, alguns animais apresentam as fibras musculares mais delicadas que outros, essa variação foi notada durante o processo de dissecção, onde, em algumas espécies as fibras musculares são tão mais resistentes sendo necessário usar a tesoura para cortar os tecidos, enquanto que em outras, as partes corporais são facilmente destacadas usando apenas as pinças.

O estado 1 (frágil) aparece no nó 15, segundo clado dentro da família Nassariidae, e se mantêm por todo gênero Phrontis e em Cyclope sp., além de convergir nas espécies Demoulia abbreviata e Hinia corticata. A partir do nó 23 o caráter reverte para o estado 0 (resistente) que agrupa todos os nassarídeos pertencentes ao gênero Nassarius e "Bullia group".

22. Opérculo, posição do núcleo: $0=$ terminal, $1=$ central $(P$. ogum, V. cassiforme, B. undatum) (CI: 33, RI: 0, L: 3).

O núcleo opercular indica a origem das voltas concêntricas que marcam o crescimento do opérculo. Opérculos arredondados tendem a ter esse núcleo posicionado mais centralmente como indicado pela análise. O estado 1 (central), ocorre como uma convergência nas espécies supracitadas. 
23. Forma do opérculo: $0=$ elíptica, $1=$ redonda $(V$. cassiforme, B. undatum, Cyclope sp.), 2= oval (Nasssariidae).

A presença de opérculo que sela a abertura da concha é uma das sinapomorfias de Gastropoda (Ponder \& Lindberg, 1997), todos os representes, supostamente, deveriam possuir um, pelo menos no estágio larval do desenvolvimento (Simone, 2011), no entanto, modificações e até perdas são encontradas.

O estado plesiomórfico (elíptico), encontra-se nos nós mais basais, nó 2, como sinapomorfia de Buccinoidea, transformando-se no estado 1 (redonda) como autapomorfias das 3 espécies citadas acima. O estado 2 (oval) aparece como sinapomorfia de Nassariidae (nó 13).

24. Opérculo com expansões: $0=$ ausente, $1=$ presente (Nassariinae) $(\mathrm{CI}: 25$, RI: 72, L: 72).

A presença de projeções em forma de espinhos nas laterais do opérculo é uma característica que surge como uma importante sinapomorfia de Nassariinae (nó 13), entretando, essa característica foi perdida nas tribos Hiniini e Bullini, nós 29 e 33 respectivamente.

25. Cabeça protuberante: $0=$ ausente, $1=$ presente $(P$. aurantiaca, $F$. frenguelli, T. roboreus, Buccinidae, Nassariidae) (IC: 12, RI: 56, L: 8).

Os clados mais basais da análise apresentam os tentáculos inseridos diretamente no dorso do animal, a partir do nó 10 o caráter passa por sua primeira transformação e há o surgimento de uma cabeça bem definida, posicionada entre os tentáculos, essa característica se mantém entre os bucinídeos e alguns nassarídeos, revertendo para a condição plesiomórfica no gênero Phrontis.

26. Tamanho dos tentáculos em relação a cabeça: $0=3 \mathrm{x}$ maior, $1=2 \mathrm{x}$ maior (Nassariidae), 2= igual ( $P$. aurantiaca, F. frenguelli, H. luteostoma, H. olivácea) 3= menor (P. tupiniquim, P. morio, T, roboreus, B. undatum) (IC: 30, RI: 46, L: 10) (deltran).

Caráter aplicável somente aos táxons que possuem uma cabeça protuberante. $\mathrm{O}$ surgimento de tentáculos de tamanho igual aos da cabeça foram os primeiros a aparecer na análise e embasa o nó 5, depois parece ter tido uma diminuição, e esses tentáculos se tornaram menores que a cabeça, sendo uma sinapomorfia do clado 7.

Em Nassariidae (nó 13), os tentáculos voltam a crescer e a condição de 2x maior que a cabeça é uma sinapomorfia deste clado. Esse crescimento em nassarídeos é tão evidente que no gênero Nassarius esse caráter passa por sua quarta modificação e reverte para a condição plesiomórfica que é, tentáculos 3x maior que a cabeça. 
27. Base dos tentáculos: $0=$ próximos, $1=$ afastados ( $P$. pusio, B. undatum, Buccinanops, Phrontis sp. 4, Nassarius, B. laevissima) (IC: 16, RI: 54, L: 6) (acctran).

Esse caráter é evidenciável comparando o espaço entre as bases dos tentáculos na inserção com o dorso do animal ou com a inserção na cabeça. Em ambas condições esse espaço se mostrou variável em táxons maiores da topologia, obviamente, que em animais que possuem cabeça essa distância seja muito mais acentuada.

28. Olhos: $0=$ ausentes, $1=$ presentes (Buccinoidea) (IC: 25, RI: 40, L: 4).

A presença de olhos, nesta análise surge como uma das sinapomorfia de Buccinoidea (nó 2), apenas 3 clados reverteram para a condição plesiomórfica de olhos ausentes, R. morrisoni, Buccinanops e "Bullia group".

29. Posição dos olhos: $0=$ fora dos tentáculos, $1=$ base dos tentáculos, $2=$ meio dos tentáculos, $3=$ ponta dos tentáculos, (IC: 75, RI: 50, L: 4) (acctran).

A presença de tentáculos cefálicos é sugerida como uma das sinapomorfias de Gastropoda (Hasprunar, 1988; Ponder \& LIndberg, 1997; Simone, 2011), o interessante aqui é a relação dos olhos com os tentáculos. Em clados mais basais dentro da Classe, olhos cefálicos são auentes (Simone, 2011).

O estado 2 se revelou como umas das sinapomorfias de Buccinoidea, e se mantém estável por quase toda a topologia ocorrendo como autapomorfias no estado 1 e 3 em $P$. aurantiaca, B. undatum e $V$. cassiforme.

30. Olhos pedunculados: $0=$ ausente, $1=$ presente $(P$. aurantiaca, L. nassa, $F$. frenguelli, V. cassiforme, T. roboreus, Phrontis sp. 2, Phrontis sp. 3, P. Incrassata, Cyclope sp., N. arcularia, N. vibex, N. polygonatus, N. coronatus, H. pulla, H. reticulata, H. corticata, D. miran) (IC: 11, RI: 44, L: 9) (acctran).

$\mathrm{Na}$ análise realizada, quando o pedúnculo ocular se faz presente, ele está localizado na região média dos tentáculos, essa estrutura não está diretamente ligada a presença ou não de olhos. A presença de olho pedunculado surge logo nos primeiros táxons da topologia (nó 2), mas foi perdido inúmeras vezes ao longo da filogenia, revertendo para o estado plesiomórfico de olhos não pedumculados, essa reversão ocorre nos nós 9, 12, 19 e em N. scabriusculus, N. luteostoma, H. olivacea.

31. Tentáculos epipodiais: $0=$ ausente, $1=$ presente (Nassariidae) (IC: 50, RI: 92, L: 2).

A presença de tentáculos epipodiais na borda posterior do pé se mostrou como uma das Sinapomorfias de Nassariidae (nó 13). 
32. Número de tentáculos epipodiais: $0=\mathrm{um}, 1=$ dois (Nassariidae, menos Buccinanops) (IC: 100, RI= 100, L= 1) (acctran).

Como dito no caráter anterior, todos os nassarídeos apresentam tentáculos epipodiais, esse número pode ser de um a dois tentáculos conforme o grupo. No elenco selecionado, a presença de um tentáculo aparece apenas na primeira subfamília de Nassariidae, Buccinanopsinae, o que sugere que um tentáculo epipodial possa ser a condição plesiomórfica dentro da familia.

A partir da subfamília Nassarinae (nó 15), o caráter passa para o segundo estado (dois tentáculos epipodiais) e se mantém assim em todas as espécies da subfamília, com exceção de E. unicinctus, que se mostrou como o único Nassariinae da análise que possui tentáculos no propódio.

33. Posição do rincóstoma: $0=$ horizontal, $1=$ vertical (Buccinoidea, - L. nassa, $P$. aurantiaca, V. cassiforme, P. tupiniquim, P. pusio, Phrontis sp. 1, Cyclope sp., N. scabriusculus, H. reticulata, B. granulosa E. unicinctus).

O rincóstoma é a abertura por onde a probóscide é evertida, nos Neogastropoda essa abertura fica localizada sob a cabeça ou entre os tentáculos, foi possível visualizar duas configurações de sentido dessa abertura, horizontal e vertical.

A condição apomórfica (sentido vertical) resultou como uma das sinapomorfias de Buccinoidea, porém o caráter sofre reversões autapomórficas em vários táxons terminais ao longo da topologia.

34. Pescoço: $0=$ ausente, $1=$ presente (Pugilina) (IC: 100, RI: 100, L: 1$)$.

Caráter sinapomórfico para o gênero Pugilina (nó 9), foi mantido por auxiliar na taxonomia desse gênero e auxiliar na organização filogenética do grupo externo.

35. Número de voltas do músculo columelar: $0=1 / 2$ volta, $1=1$ volta $(R$. morrisoni, V. cassiforme, T. roboreus, Buccinanops, Phrontis, N. scabriusculus, N. coronatus, H. reticulata, Bullia, Cyclope sp.), 2=1 1/2 volta (Fasciolariidae, Pugilina, Buccinidae, Phrontis alba Noronha, H. olivacea, E. unicinctus) (IC: 14, RI: 42, L: 14) (deltran).

O músculo columelar é uma importante estrutura dos gastrópodes, é responsável pela fixação do animal na concha e também pela rápida contração para seu interior ao menor sinal de perigo.

O estado 2 surge no nó 1, provavelmente por que esses animais possuem um canal sifonal e columela alongados, a partir do nó 6 o caráter passa por sua primeira transformação para o estado 1, e sofre um encurtamento no tamanho do músculo 
columelar. Já dentro da família Nassariidae o caráter sofre sua segunda transformação, agora revertendo para o estado 2, e passa por mais um encurtamento, essa modificação é sinapomorfia dos gêneros Nassarius e Hinia.

36. Glândula de cimento: $0=$ ausente, $1=$ presente (T. laevigata, Fasciolariidae, V. cassiforme, Pugilina, T. roboreus, N. vibex, P. Incrassata, D. miran, Bullia, E. unicinctus) (IC: 14, RI: 57, L: 7) (acctran).

A glândula de cimento é uma estrutura única presente somente nas fêmeas, situada na linha mediana da região anterior da sola do pé, por conta disso pode ser chamada as vezes de glândula pedal ventral (Fretter \& Graham, 1962; Strong, 2003). Essa glândula auxilia na fixação das capsulas de ovos no substrato e, por sua vez, também na moldagem final dessas capsulas.

O estado 1 (presente), surge como uma das sinapomorfias de Buccinoidea, porém essa característica só se mantém nos táxons mais basais na topologia, e.g., Fasciolariidae, a partir do nó 11, que une Buccinidae e Nassariidae essa característica é perdida e os animais voltam ao estado plesiomórfico (ausência).

37. Posição da glândula pediosa: $0=$ perto da borda do pé, $1=$ afastado da borda do pé (P. ogum, P. pusio, Phrontis sp. 3, Cyclope sp., N. arcularia, N. coronatus, H. olivácea, E. unicinctus) (CI: 12, RI: 0, L: 8) (deltran).

A glândula pediosa ou glândula de muco se mostrou posicionada de duas maneiras nos animais analisados, a primeira é situada bem na linha mediana da sola do pé, e assim, afastada da borda do pé; na segunda maneira essa glândula fica situada na linha anterior da região do propódio, encostada no limite da borda do pé.

Em sua grande maioria o estado plesiomórfico (perto da borda do pé), apareceu em quase todos os animais da topologia. O estado derivado (afastado da borda do pé), aparece apenas como autapomorfia das espécies citadas acima.

38. Abertura da glândula pediosa: $0=\mathrm{em}$ forma de sulco, $1=\mathrm{em}$ forma de poro (T. laevigata, Fasciolariidae, V. cassiforme, Pugilina, P. pusio, P. Incrassata, Phrontis sp. 2, Phrontis sp. 1, Cyclope sp. N. coronaus, H. olivacea, D. miran, E. unicinctus) (IC: 8, RI: 26, L: 12) (acctran).

Aparentemente a forma da abertura da glândula pediosa não tem relação com sua localização na sola do pé (caráter 37), ambas configurações foram visualizadas nas duas posições citadas acima. 
O estado 1 (forma de poro), ocorre primeiramente no nó 1 com convergência no nó 16 e 37. Já a abertura em forma de sulco (estado 0) ocorre independentemente a nos nós 6 e 23.

39. Forma da Hemocela: $0=$ estreita, 1= ampla (Buccinoidea), $2=$ triangular (Fasciolariidae) (IC: 16, RI: 41, L: 12) (acctran).

A forma da hemocela tem relação direta com a disposição das suas estruturas internas, por exemplo, forma, comprimento e largura da probóscide, diâmetro do esôfago, presença ou ausência de glândula de Leiblein, etc.

O caráter passa por diversas transformações ao longo da topologia, o estado 0 (estreita) se mostrou como uma das sinapomorfias de Buccinoidea com convergência nos nós 18, 32, 37. O estado 1 (ampla) embasa os nós 15 (Nassariinae), enquanto que, o estado 2 (triangular) mais derivado, aparece apenas no nó 4 um subgrupo da família Fasciolariidae.

\section{3. Órgão paliais}

40. Comprimento da cavidade palial: $0=3 / 4$ de volta, $1=1$ volta ( $T$. laevigata, Fasciolariidae, P. tupiniquim, B. gradatus, P. Incrassata, Phrontis sp. 4, Cyclope sp., Nassarius, Hinia, D. miran, Bullia, D. abreviata, E. unicinctus), $2=11 / 2$ volta $(V$. cassiforme, P. morio, T. roboreus, Buccinidae, B. moniliferum, Phrontis sp. 3, Phrontis sp. 2, Phrontis sp. 1, Phrontis albaN. Coronatus, H. olivacea) $3=2$ voltas (R. morrisoni) (IC: 27, RI: 38, L: 11) (acctran).

O comprimento da cavidade palial, na verdade, corresponde ao tamanho do manto do animal. Na ordem Neogastropoda essa estrutura se estende por todo o dorso do animal e abrange desde o sifão até a massa visceral, em seu interior (cavidade) estão localizados os órgãos paliais, brânquias, osfrádios, rins e órgãos sexuais.

O estado 1 (uma volta) aparece como uma das sinapomorfias de Buccinoidea (nó 2), e mantém esse status da família Fasciolariidae até o nó 7, onde transforma para o estado 2 (1 1/2 volta), porém o estado 1 volta a aparecer novamente na reversão de alguns táxons deste clado. A partir do nó 16 o estado 1 volta como uma sinapomorfia, e aí sim, abrange todos os terminais restantes na topologia.

41. Borda do manto: $0=$ grossa, $1=$ fina (R. morrisoni, V. cassiforme, Pugilina, Phrontis, Cyclope sp., H. pulla, B. laevisssima, D. abreviata) (IC: 14, RI: 53, L: 7).

A borda do manto se torna caracteristicamente fina nos táxons situados nos nós 7 e 15 e nas espécies citadas acima como convergência autapomórfica. 
Esse afinamento da borda do manto parece estar a ligado aos animais que não apresentam a tendência de hipertrofiar o lábio interno da concha, como mostrado na análise deste caráter na fillogenia resultante.

42. Tamanho do sifão em relação a massa cefalopediosa: $0=$ curto, até a 1/2, $1=$ longo, maior que a 1/2 (F. frenguelli, Pugilina, Buccinidae, Phrontis sp. 3, Phrontis sp. 4, Phrontis alba, $N$. arcularia, $N$. coronatus, H. luteostoma, H. reticulata, D. miran, $B$. granulosa, D. abbreviata, E. unicinctus) (IC: 9, RI: 41, L: 11) (deltran).

Todos os Buccinoidea apresentam um sifão projetado, bem desenvolvido, a partir do lado esquerdo do manto. $\mathrm{O}$ independe da projeção sifonal da concha, portanto, conchas que aparentemente apresentam um canal sifonal curto ou ausente o animal não necessariamente precisa seguir esse padrão, o que de fato acontece com todos os animais selecionados para análise. O que acontece é que alguns animais desenvolveram um sifão extremamente longo, que se estende por mais da metade da extensão de todo o animal, essa característica é presente em alguns fasciolarídeos, bucinídeos, algumas espécies do gênero Phrontis e Hinia.

43. Borda direita do sifão: $0=$ alta, $1=$ baixa $(P$. ogum, $R$. morrisoni, Pugilina, $T$. roboreus, B. undatum, $P$. Incrassata, Phrontis sp. $1, H$. reticulata, Bullia) $2=$ terminando gradativamente no teto palial (L. nassa, Phrontis sp. 3, P. alba) (deltran).

O estado plesiomórfico se mantém por toda a topologia, surgindo nó 1. A transformação para o estado 1 ocorre independentemente como convergência nas espécies citadas acima e como sinapomorfia do gênero Pugilina, assim também acontece com o estado 2, que surge como autapomorfia para as espécies L. nassa, Phrontis sp. $3 e$ Phrontis alba.

44. Prega entre a brânquia e o osfrádio: $0=$ ausente, $1=$ presente $(T$. laevigata, $P$. tupiniquim, Buccinidae, Phrontis sp. 2, N scabriusculus, N. vibex, H. luteostoma, $H$. reticulata, Bullia group) (IC: 10 RI: 30, L: 10) (acctran).

Assim como o caráter anterior, o estado plesiomórfico deste caráter surge como uma sinapomorfia no nó 1 e se mantém até o nó 12, onde se transforma no estado 1 como uma sinapormofia da família Buccinidae. Esse estado ainda ocorre como uma convergência no nó 23, já pertencente ao grupo interno. Essa característica se mantém por algumas espécies dentro de Nassariinae, abrangendo 4 gêneros. 
45. Afilamento anterior da brânquia: $0=$ ausente, $1=$ presente ( $T$. laevigata, Fasciolariidae, R. morrisoni, V. cassiforme, B. undatum, B. gradatus, Phrontis, Cyclope sp., N. arcularia, N. coronatus, Hinia, D. miran, B. laevissima, E. unicinctus) (IC: 7, RI: 25, L: 13) (acctran).

A forma das brânquias dos moluscos são geralmente uma importante fonte de características utilizadas em classificações taxonômicas e análises filogenéticas. No elenco selecionado para a análise não foi diferente e uma série de informações foram tiradas dos ctenideos.

A brânquia com afilamento anterior surge no nó 1 , com duas convergências sinapomórficas nos nós 19 e 22, porém o estado plesiomórfico volta a aparecer como sinapomorfias nos nós 24 e 32.

46. Afilamento posterior da brânquia: $0=$ ausente, $1=$ presente (L. nassa, $R$. morrisoni, F. frenguelli, B. undatum, Buccinidae, Phrontis alba, Cyclope sp., Nassarius, H. reticulata, $H$. olivacea, $B$. laevissima).

Diferentemente do afilamento anterior a brânquia, o estado derivado aparece somente em táxons mais terminais da análise, como convergências. Na família Buccinidae e no gênero Nassarius essa característica aparece como sinapomorfia.

47. Forma do filamento branquial: $0=$ triangular, $1=$ arredondado ( $T$. laevigata, R. morrisoni, V. cassiforme, P. morio, Phrontis sp. 4, N. coronatus, H. reticulata, $H$. olivácea, E. unicinctus), 2= pontiaguda ( $P$. tupiniquim, $P$. Incrassata, $H$. corticata $), 3=$ baixo e arredondado (N. scabriusculos, N. arcularia, Bullia, Demoulia abbreviata) (IC: 23, RI: 28, L: 13) (acctran).

A forma individual de cada filamento branquial também se mostrou bastante variável e informativo para a analise. O estado 1 embasa os nós 7 e 31 . O estado 2 aparece como autapomorfias desses três táxons terminais apresentados acima e o estado 3 surge como sinapomorfia do nó 23 .

48. Comprimento da brânquia: $0=5 / 6$ da cavidade palial, $1=1 / 2$ da cavidade palial (F. frenguelli, B. gradatus, Phrontis sp. 3, P. Incrassata, Phrontis alba, Cyclope sp., Hinia), 2=2/3 da cavidade palial ( $P$. ogum, P. aurantiaca, V. cassiforme, Phrontis sp. 2, Phrontis sp. 1, Phrontis sp. 4, N. vibex) (IC: 16, RI: 47, L: 12) (deltran). 
49. Comprimento do osfrádio: $0=$ equivalente ao da brânquia, $1=2 / 3$ da brânquia (Buccinoidea), $2=1 / 2$ da brânquia ( . cassiforme, Pugilina), $3=1 / 3$ da brânquia $(B$. moniliferum, D. miran, B. granulosa) (IC: 28, RI: 41, L: 5) (acctran).

O osfrádio é um órgão sensitivo, principalmente de olfação, e fica localizado na base do sifão, anterior a brânquia. Em caenogastrópodes superiores e, principalmente em Neogastropoda o osfrádio se modificou e se especializou, tornando-se uma variz ganglionar bi-pectinada. Sendo o osfrádio um órgão sensitivo, é plausível inferir que com seu aumento, maior será seu contato com a água e, portanto, maior será sua sensibilidade (Simone, 2011).

De acordo com a árvore obtida o estado 1 aparece como sinapomorfia do nó 1 e se mantém por quase todas as espécies desse táxon, apenas no nó 8 e 34 esse caráter se transformou e são suportados pelo estado 2 e 3 respectivamente.

50. Limite anterior do osfrádio: $0=$ perto da borda do manto, $1=$ afastado da borda do manto (L. nassa, P. ogum, R. morrisoni, Pugilina, T. roboreus, B. moniliferum, $H$. reticulata, $H$. corticata, $H$. olivacea, $B$. laevissima) (IC: 14, RI: 40, L: 7).

Embora o osfrádio, em Buccinoidea, fique sempre localizado na base do sifão, foi possível visualizar, suaves, variações em sua posição. Em alguns casos a linha média do osfrádio está localizada imediatamente na abertura do sifão e, portanto, seu limite anterior é mais próximo da borda do manto, e em outros casos o osfrádio se localiza, posteriormente a borda esquerda do sifão, o que deixa seu limite anterior afastado da borda do manto.

O estado 1 surge como convergência sinapomórfica dos nós 2 e 31 e como autapomorfias das espécies supracitadas.

51. Filamento do osfrádio: $0=$ ligados ao manto, $1=$ projetados a partir do manto (T. laevigata, L. nassa, R. morrisoni, P. tupiniquim, P. pusio, P. Incrassata, N. scabriusculos, N. arcularia, H. luteostoma, H. reticulata, H. olivacea, “Bullia group”) (IC: 9, RI: 28, L: 11).

Embora, aparentemente, todos os filamentos dos osfrádios nas espécies examinadas sejam muito semelhantes e possivelmente homólogos, ao realizar o corte transversal da estrutura foi possível visualizar dois tipos de configurações, a primeira mostrou um filamento colado ao manto, desde a base próximo ao gânglio até a extremidade posterior do filamento. A segunda configuração revelou, apenas, que a base e o gânglio estavam conectados ao manto e o gânglio, por sua vez, estava livre do teto palial, projetado ventralmente. 
De acordo com a árvore resultante essa característica suporta o nó 23 dentro de Nassariidae e é autapomorfias de alguns táxons do grupo externo.

52. Largura do osfrádio em relação a brânquia: $0=$ tão largo quanto, $1=1 / 2 \mathrm{da}$ largura (Buccinoidea), 2=1/3 da largura (B. gradatus, B. laevissima) (IC: 14, RI: 29, L: 14) (acctran).

53. Localização do osfrádio na cavidade palial: $0=$ anterior, $1=$ posterior $(H$. corticata), 2= ao longo de toda extensão (B. laevissima), $3=$ médio (Fasciolariidae, $R$. morrisoni, T. roboreus, P. pusio, Hinia, E. unicinctus) (CI: 30, RI: 22, L: 10) (deltran).

A mesma argumentação usada no caráter 50 é válida para este. O estado 3 é o único entre todos que embasou um táxon (nó 31), os demais surgiram como autapomorfias de táxons terminais citados acima.

54. Glândula anal: 0= ausente, $1=$ presente (T. laevigata, Buccinidae (IC: 50, RI: 50, L: 2).

Mesmo que a presença de uma glândula anal seja citada como uma sinapomorfia de Neogastropoda (Kantor, 1997), apenas dois táxons na análise mantiveram essa estrutura, de acordo com o resultado a presençade glândula anal é uma das sinapomorfias da família Buccinidae.

55. Tamanho da massa visceral: $0=$ médio, até $1 / 3$ do volume do animal, $1=$ pequena, menor que 1/3 (L. nassa, P. ogum, R. morrisoni, V. cassiforme, Buccinidae, Buccinanopsinae, Phrontis, H. pulla, B. laevissima) (IC: 12, RI: 53, L: 8).

\subsection{Sistema circulatório}

56. Aurícula: $0=$ muscular, $1=$ membranosa $(R$. morrisoni, $T$. roboreus, Buccinidae, Nassariinae menos Hinia) (IC: 14, RI: 66, L: 7). (acctran).

Os Monotocardia (Caenogastropoda+ Heterobranchia) possuem apenas uma aurícula, diferentemente de gastrópodes mais basais, e.g., Neritimorpha, essa característica, obviamente, é mantida nos Neogastropoda e embora todos os animais analisados sejam monotocárdios, foi possível visualizar dois tipos de aurículas. Uma do tipo muscular e outra membranosa.

A presença de aurícula membranosa, estado derivado, surge a partir do nó 7 e se mantém até o nó 27, onde reverte para o estado plesiomórfico 0 no gênero Hinia e em "Bullia group".

57. Tamanho do coração e pericárdio: $0=1 / 4$ do tamanho do rim, $1=1 / 2$ do tamanho do rim (R. morrisoni, V. cassiforme, P. morio, B. undatum, B. moniliferum Phrontis sp. 3, Phrontis alba, Cyclope sp., H. luteostoma, Hinia menos H. pulla, D. miran, 
D. abbreviata), $2=1 / 3$ do volume do rim (a partir do nó 10), $3=$ equivalente ao volume do rim (Phrontis sp. 4, H. pulla) (IC: 18, RI: 31, L: 16) (deltran).

Caráter que passou por bastantes transformações ao longo da topologia. O estado 1 convergentemente embasa os nós 7,21, 30 e ainda é autapomorfia dos táxons terminais citados acima. De acordo com a árvore resultante, o estado 2 é o que se mostrou mais estável na análise, além de surgir como autapomorfia de duas espécies do grupo externo, também é uma das sinapomorfias do nó 10 e se mantém em todos as espécies a partir dai, exceto nas espécies que reverteram para o estado 1, citadas no título desse caráter. $\mathrm{O}$ estado 3 se mostrou apenas como autapomorfia de Phrontis sp. 4 e Hinia pulla.

58. Aorta com bulbo: $0=$ ausente, $1=$ presente $(P$. morio $)$.

Este caráter é mais um a auxiliar na organização do grupo externo e na taxonomia do gênero Pugilina.

59. Reforço membranoso entre $o$ vaso ctenidial e aorta: $0=$ ausente, $1=$ presente (P. ogum, F. frenguelli, nó 16 menos Phrontis sp. 2, Nassarius, H. luteostoma, H. olivacea) (IC: 12, RI: 58, L: 8) (acctran).

Algumas espécies apresentaram um reforço membranoso na conexão entre o vaso ctenidial, que vem da brânquia, e a aurícula, essa membrana se funde ao pericárdio, e possivelmente, torna essa conexão entre essas estruturas mais resistente.

O estado 1 ocorre como convergência sinapomórfica entre os nós 4 e 16, a partir deste último segue presente até o final da topologia.

\subsection{Sistema excretor}

60. Posição do nefróstoma: $0=$ longitudinal, $1=$ transversal (nó 1 exceto $P$. aurantiaca, V. cassiforme, Pugilina, Phrontis, N. scabriusculus, H. olivacea) (IC: 14, RI: 33, L: 7) (acctran).

O nefróstoma é a abertura localizada na membrana que envolve a região anterior do rim e é responsável pela excreção liquida do animal, a urina.

A posição transversal (derivada) aparece no nó 1, e se mantém por quase toda a topologia, exceto nos nós 8 e 19, gênero Hinia, onde o caráter passa por uma reversão para o estado plesiomórfico (sentido longitudinal).

61. Borda do nefróstoma: $0=1$ lisa, $1=$ labiada $(P$. aurantiaca, $P$. tupiniquim, Buccinidae, P. Incrassata, Phrontis sp. 4, Phrontis alba, H. pulla, B. laevissima) (IC: 14, RI: 33. L: 7). 
Embora todos nefróstomas analisados apresentem uma espécie de diafragma regulador, em determinados casos esse mecanismo é reforçado por um espessamento da borda da abertura, parecendo um lábio.

O caráter se comporta como convergência sinapomórfica nos nós 14 e 20, família Buccinidae e um subgrupo dentro do gênero Phrontis respectivamente.

62. Tamanho da aurícula em relação ao ventrículo: $0=$ igual, $1=$ menor que a metade $($ Buccinoidea $), 2=$ maior que a metade $(P$. tupiniquim, $B$. undatum $), 3=$ metade (T. larvigata, L. nassa, Phrontis sp. 4, Hinia) (IC: 25, RI: 18, L: 12) (acctran).

63. Comprimento do rim: $0=$ menor que $1 / 4$ de volta, $1=1 / 4$ de volta $(P$. ogum, $P$. Incrassata, $H$. luteostoma, $H$. reticulata, $H$. olivacea), $2=1 / 3$ de volta (demais Buccinoidea), $3=1 / 2$ da volta (B. undatum, N. arcularia, H. pulla, H. corticata, E. unicinctus) (IC: 20, RI: 29, L: 15). (deltran).

Aparentemente o tamanho do rim tem relação direta com o tamanho do pé, isso porque, quando o pé é retraído todo o sangue utilizado para desinflá-lo é armazenado no rim (Fretter \& Graham, 1962).

O estado 2 surge como uma das sinapomorfias de Buccinoidea e como convergência no nó 35, gênero Bullia. O estado 1 embasa apenas o nó 30, enquanto que, o nó 3 aparece apenas como autapomorfias dos terminais citados acima.

64. Tecido renal: $0=$ maciço, $1=$ com câmaras (T. laevigata, FasciolariidaeR. Morrisoni, V. cassiforme, P. morio, Buccinidae, Buccinanopsinae, Phrontis sp. 3, Phrontis sp. 4, Hinia, B. laevissima, D. abbreviata) (IC: 11, RI: 55, L: 9).

Em Caenogastropoda o tecido renal é comumente glandular e oco, dividido em câmaras, essa característica surge logo no nó 1 e se mantém até o nó 16, onde o rim sofre uma reversão para o estado 0 (maciço). O formato de uma glândula preenchida com tecido, aparentemente uniforme e maciço é comumente encontrado em grupos mais basais dentro dos gastrópodes, e.g., arqueogastrópodes (Simone, 2011). Mas de acordo com a arvore resultante essa característica volta a acontecer em Nassariidae. 


\subsection{Sistema digestivo}

65. Parede rincodeal: 0 muscular delgada, $1=$ membranosa $(R$. morrisoni, $V$. cassiforme, Pugilina, Phrontis sp. 1, H. corticata, E. unicinctus), 2= muscular desenvolvida (T. laevigata, P. aurantiaca, F. frenguelli, Buccinidae, N. coronatus, $H$. lutostoma, H. olivacea, D. miran D. abbreviata) (IC: 18, RI: 47, L: 11).

A probóscide dos Neogastropoda é exclusivamente do tipo pleurembólica, isso é, uma probóscide com inversão total para dentro da cavidade rincodeal, a estrutura que a porção restante da cavidade rincodeal na retração da probóscide é denominada de parede rincodeal (Simone, 2011).

A condição plesiomórfica (muscular delgada) surge como sinapomorfia de Buccinoidea e se mantém até o nó 28 . O estado 1 surge como convergência e embasa os nós 7 e 35, enquanto que, o estado mais derivado (muscular desenvolvida) surge como sinapomorfia da família Buccinidae e do nó 28 que une o gênero Hinia e o "Bullia group".

66. Músculos retratores da probóscide: $0=$ um par ventral, $1=$ vários pares circundando a base da probóscide (Buccinoidea), 2= vários pares circundando toda a probóscide (L. nassa, Buccinidae, N. vibex, H. luteostoma, H. olivacea, B. laevissima, E. unicinctus) (IC: 18, RI: 25, L:11) (deltran).

Esse conjunto muscular é responsável pela retração da probóscide na cavidade rincodeal. Em Buccinoidea a condição plesiomórfica é o estado 1 que se mantém por toda a topologia com exceção da família Buccinidae e Nassarius "sensu strictu" onde o estado 2 aparece como sinapomorfia.

67. Tubo oral: $0=$ pregueado, $1=$ liso (a partir do nó 2) (IC: 12. RI: 22, L: 8) (acctran).

A condição derivada surge no nó 2 e se mantém por toda a topologia. Apenas o gênero Pugilina e B. gradatus, H. pulla, B. laevissima e D. abbreviata revertem para o estado plesiomórfico dentro do grupo interno.

68. Probóscide: $0=$ curta, $1=$ longa (Buccinoidea) (IC: 11, RI: 0, L: 9) (acctran).

Como a probóscide é uma estrutura retrátil, é difícil estipular seu tamanho exato, porém, esse caráter foi baseado no espaço que a probóscide ocupa dentro da hemocela quando retraída, portanto, foi considerada longa quando ocupa toda a extensão da cavidade hemocélica.

O estado 1 surge como sinapomorfia da superfamília Buccinoidea e se mantem estável por toda a topologia com exceção das espécies P. ogum, V. cassiforme, Phrontis sp. 3, P. incrassta, H. pulla, H. corticata e B. laevissima que mantiveram o estado 
plesiomórfico de probóscide curta, ou seja, que não ocupa toda a cavidade hemocélica quando retraída.

69. retração da probóscide: $\mathrm{o}=$ simples, $1=$ enrolada (Pugilina) (IC: 100, RI: 100, L: 1).

Caráter diretamente relacionado ao caráter anterior, o estado 1 surge apenas como sinapomorfia do gênero Pugilina, que apresenta uma probóscide extremamente longa, que quando retraída não cabe por inteira na cavidade hemocélica, e para tal, é necessário se enrolar na porção mediana para conseguir ser totalmente retraída.

70. Esôfago anterior: diâmetro em relação ao odontóforo: $0=$ menor, $1=$ igual (a partir do nó 2), 2= maior (T. laevigata, P. aurantiaca, Phrontis sp. 2, N. coronatus, $H$. corticata, D. abbreviata) (IC: 20, RI: 20, L: 10).

71. Pregas no esôfago anterior: $0=$ ausentes, $1=$ presentes (Buccinoidea exceto nós 5, 9, 12, 25, 33) (IC: 14, RI: 60, L: 7).

72. Número de pregas, quando presentes, no esôfago anterior: $0=$ duas, $1=$ uma (T. laevigata, $P$. aurantiaca), 2= mais que duas (E. unicinctus) (IC: 100, RI: 100, L: 2).

Caráter aplicável, obviamente, aos animais que possuem tal estrutura (citados no caráter anterior), na grande maioria dos animais examinados a reversão para o estado 0 é a que mais ocorre, a presença de uma prega surge como sinapomorfia do nó 1, mas logo é revertido para o estado 0 no nó 6, já a condição com mais do que duas pregas (estado 2) é encontrado apenas como autapomorfia na espécie E. uninctus, o que denota seu alto grau de variação anatômica e que o distancia da família Buccinidae.

73. Esofago médio: $0=$ estreito, $1=$ alargado (Buccinoidea exceto $T$. roboreus e gênero Pugilina). (IC: 33, RI: 33, L: 3).

74. Glândula de Leiblein: $0=$ presente, $1=$ ausente (Buccinoidea exceto $V$. cassiforme, Pugilina, T. roboreus, H. olivacea, B. laevissima) (IC: 25, IC: 40, L: 4).

Como proposto por Kantor (1997), Ponder (1973) e Haszprunar (1988), a presença de glândula de Leiblein é a condição plesiomórfica para a ordem Neogastropoda, e na análise realizada, de fato, tal proposta foi corroborada e a presença da estrutura surge como sinapomorfia do nó 1 , entretanto, algumas espécies dentro da superfamília Buccinoidea perderam essa estrutura.

75. Valvula de Leiblein: $0=$ presente, $1=$ ausente $($. cassiforme, Pugilina, $H$. olivacea, B. laevissima) (IC: 33, RI: 50, L: 3).

Assim como a glândula de Leiblein, a presença da válvula de Leiblein é a condição plesiomórfica dentro da superfamília Buccinoidea (Simone, 2011) e surge como uma de 
suas sinapomorfias. Apenas os mesmos táxons que não apresentam glândula de Leiblein (citados acima), também não possuem a válvula de Leiblein, embora a presença de uma não é dependente da existência da outra como citado por Kantor \& Fedosov (2009).

76. Ducto da glândula de Leiblein: $0=$ curto, $1=$ longo (Buccinoidea exceto L. nassa, F. frenguelli, Buccinidae, Phrontis sp. 2, Cyclope sp., D. miran, B. granulosa). (IC: 14, RI: 25, L: 7).

A inserção da glândula de Leiblein se dá diretamente entre o esôfago médio e posterior, logo após o anel nervoso, a presença de um ducto longo e fino aparece como sinapomorfia do nó 1 e se mantém por toda a topologia. O carater sofre poucas transformações para o estado derivado, e a presença de um ducto curto surge nas espécies citadas acima.

77. Posição da abertura dos ductos salivares no tubo oral: $0=$ meio, $1=$ anterior (T. laevigata, P. aurantiaca, F. frenguelli, R. morrisoni, V. cassiforme, Pugilina, Phrontis, nó 22), 2= posterior (Buccinidae, N. coronatus, H. corticata, H. olivacea) (IC: 20, RI: 33, L: 10), (acctran).

Os ductos salivares correm paralelamente ao esôfago médio e anterior, e como já citado por Ponder (1974) livres do anel nervoso. Sua inserção nas paredes do esôfago anterior acontece, quando, ambas estruturas se interiorizam na probóscide, isso acontece para todos os táxons analisados. Porém, a posição da abertura destes ductos no tubo oral se mostrou variável, podendo ser bem anterior, quase na boca, na porção mediana e até na porção posterior, bem ao final do tubo oral.

O estado 1 surge como sinapomorfias nos nós 1, 19 e 22 e o estado 2 como sinapomorfias dos nós 14 e 32, sugerindo sua homologia entre esses táxons.

78. Presença de bulbo na região anterior do ducto salivar: $0=$ ausente, $1=$ presente (Pugilina) (IC: 100, RI: 100, L: 1).

Caráter sinapomórfico para o gênero Pugilina, mantido para auxiliar na taxonomia desse gênero e na organização do grupo externo.

79. Esôfago posterior: diâmetro constante ao longa de sua extensão: $0=$ ausente, 1= presente (nó 7, Phrontis sp. 1, B. laevissima, D. abbreviata, E. unicinctus) (IC: 20, RI: 33, L: 5).

80. Esôfago anterior: abaulamento na região anterior: $0=$ ausente, $1=$ presente (nó 7, Phrontis sp. 1, B. laevissima, D. abbreviata, E. inicinctus).

81. Presença de seco no esôfago: $0=$ ausente, $1=$ presente $(R$. morrisoni) $(\mathrm{IC}, \mathrm{RI}:$ UNINF, L: 1). 


\subsection{Odontóforo}

82. $\mathrm{Mj}: 0=$ pequeno circundando a região anterior do odontóforo, $1=$ hiperatrofiado (B. undatum, nó 28 exceto $H$. reticulata, D. abbreviata) (IC: 25, RI: 62, L: $4)$.

O mj é um par de músculos que forma a região peri-oral, sua principal função é servir de esfincterbucal, ocluindo a boca, é constituido de fibras circulares que envolvem a circunferência da boca.

Em Buccinoidea é comumente pequeno e circunda apenas a região bucal, mas a partir do nó 28 , esse conjunto muscular hipertrofia e excede a região bucal. Essa característica converge na espécie $B$. undatum da família Buccinidae.

83. Numeros de feixes do M2: 0= um par, 1= dois pares (P. ogum, Pugilina, Buccinidae, P. Incrassata, H. pulla, H. corticata, E. unicicntus), $2=$ único (nó 10 exceto Phrontis alba, Nassarius “stricto sensu”, H. olivacea, B. laevissima) (IC: 15, RI: 47, L: 13) (deltran).

O m2 é o par de músculos retratores da massa bucal e tem origem no soalho da cavidade hemocélica. Surge como sinapomorfia do nó 1 no estado 0 com convergências nos nós 21 e 25. No gênero Pugilina e nas espécies de bucinídeos analisadas o carater se transforma para o estado 1 e aparece como sinapomorfia para esses dois clados.

A partir do nó 10 passa para o estado 2 de transformação e se mantém assim por todos nassarídeos.

84. M2a: $0=$ ausente, $1=$ presente (Buccinoidea exceto nós 20 e 30) (IC: 25, RI: 66, L: 4).

É um par de músculos auxiliares retratores da massa bucal, originam-se nas extremidades posteriores das cartilagens do odontóforo. Se faz presente como sinapomorfia do nó 2.

85. M2b: $0=$ ausente, $1=$ presente $(P$. aurantiaca, V. cassiforme, Pugilina, Buccinidae, N. vibex, E. unicinctus) (IC: 16, RI: 44, L: 6) (acctran).

Mais um par de músculos auxiliares da retração da massa bucal, quando presentes são quase do mesmo tamanho que o conjunto de M2.

86. M2c: $0=$ ausente, $1=$ presente (Phrontis sp. 3, Phrontis alba, H. reticulata, Bullia) (IC: 25, RI: 40, L: 4).

Outro par de músculos auxiliares da retração da massa bucal, porém, quando presentes são muito menores que seus precendentes. 
87. Paredes do M3: 0= delgadas, 1= espessas (Nassariidae exceto gênero Phrontis) (CI: 11, RI: 27, L: 9) (deltran).

Músculo cilíndrico que forma a parede externa do odontóforo, nos animais analisados se mostrou com duas características, podendo ser bem delgado ou bastante desenvolvido com fibras fortes.

A presença de fibras espessas surge como sinapomorfia da famnilia Nassariidae e converge em algumas espécies do grupo externo e no gênero Pugilina.

88. Direção das fibras do M3: 0= longitudinais, 1= transversais (Buccinoidea exceto B. undatum, Phrontis alba, H. corticata, Bullia) (IC: 20, RI: 33, L: 5).

89. Origem do M4: $0=$ separada da origem do M5, 1= não separada da origem do M5 (Fasciolariidae, Buccinidae, Phrontis sp. 3, Hinia, B. laevissima) (IC: 14, RI: 33, L: $7)$.

Os músculos m4 e m5, orignam-se na extremidade posterior das cartilagens, externa e internamente, respectivamente. Nos clados citados no enunciado deste carater, essa origem não é visivelmente separada uma da outra. Esse estado aparece como sinapomorfia da família Fasciolariidae e convergindo no nó 30, subgrupo do gênero Hinia.

90. extensão do M6 em relação as cartilagens: $0=$ até a metade, $1=$ até $1 / 3$ (Pugilina, $H$. reticulata), $2=$ toda a extensão $(P$. aurantiaca, $F$. frenguelli, V. cassiforme, Buccinidae, B. gradatus, Phrontis sp. 3, P. Incrassata, Phrontis sp. 1, Phrontis sp. 4, H. luteostoma, $H$. corticata, B. granulosa, D. abbreviata, E. unicinctus), $3=2 / 3$ (L. nassa, P. ogum, B. moniliferum, Phrontis sp. 2, Phrontis alba, Cyclope sp., Nassarius "strictu sensu”, N. coronatus H. pulla H. olivacea, D. miran) (IC: 21, RI: 38, L: 14) (acctran).

O m6 situa-se entre as cartilagens, esquerda e direita, preenchendo o espaço entre elas. Em Neogastropoda o m6 tornou-se muito delgado, ainda assim, é um musculo muito fácil de se visualizar e de se comparar entre as espécies.

Por conta disso é um musculo bastante informativo e que passou por uma série de transformações ao longo da topologia. $\mathrm{O}$ estado 1 aparece como sinapomnorfia do gênero Pugilina e reaparece como autapomorfia de $H$. reticulata. O estado 2 surge como sinapomorfia do nó 2 e reaparece no nó 28 , assim como a condição mais derivada que surge nos primeiros táxons da analise e volta a reaparecer convergentemente no nó 22.

91. Extensão do $m 8$ em relação ao odontóforo: $0=1 / 3,1=1 / 4(T$, laevigata, $P$. aurantiaca, $P$. Incrassata, Cyclope sp., Nassarius “strictu sensu”), 2=1/5 (V. cassiforme, 
Buccinidae, Phrontis sp. 3, Phrontis sp. 2, Phrontis sp. 1, Phrontis alba, H. pulla, H. reticulata, $H$. luteostoma, B. laevissima) (IC: 18, RI: 47, L: 11) (acctran).

92. Cartilagens do odontóforo fundidas: $0=$ ausente, $1=$ presente (Buccinoidea) (IC: 100, RI: 100, L:1).

Comumente em Neogastropoda as cartilagens do odontóforo tem sua região anterior fundidas entre si, essa característica se confirmou na analise e essa carater surge como sinapomorfia do nó. Apenas a espécie T. laevigata não apresentou essa configuração, assim como boa parte dos grupos mais basais de Neogastropoda (Simone, 2011).

93. Grau de fusão das cartilagens em relação a extensão do odontóforo: $0=1 / 3$, 1=1/4 (L. nassa, P. ogum, Phrontis sp. 1, Phrontis sp. 4, Phrontis alba, N. scabriusculus, N. coronatus, H. corticata, D. abbreviata), 2=1/5 (Pugilina, T. roboreus, Buccinidae, Phrontis sp. 2, “Bullia group”), 3= 1/7 (P. aurantiaca, V. cassiforme, Phrontis sp. 3) (IC: 18, RI: 38, L: 16) (acctran).

Caráter muito homoplástico, e por conta disso, muito diluído ao longo da topologia. Nenhum clado monofilético é sustentado $100 \%$ por algum estado, sempre ocorre alguma transformação, tanto convergências como reversões, mesmo em espécies muito próximas, por exemplo, no complexo de espécies Phrontis alba.

\subsection{Rádula}

94. Dente raquidiano, numero de cúspides: $0=$ multicuspidado, $1=$ até 3 cúspides (T. laevigata, Fasciolariidae, V. cassiforme, P. tupiniquim, T. roboreus, P. pusio) (IC: 33, RI: 71, L: 3).

A presença de um dente central radular surge como sinapomorfia de Buccinoidea, e se mantém nos primeiros táxons da topologia. A partir da família Nassariidae, o carater passa por uma reversão e todos os integrantes da família apresentam o dente raquidiano multicuspidado.

95. Dente raquidiano com cúspides secundarias: $0=$ ausente, $1=$ presente (Pugilina, P. pusio) (IC: 50, RI: 50, L: 2).

A ausência de cúspides secundarias no dente raquidiano, se mantém uniforme em todas as espécies da análise, o estado derivado surge apenas como sinapomorfia do gênero Pugilina e como autapomorfias de P. pusio.

96. Dente lateral: $0=$ bicuspidado, $1=$ multicuspidado (Fasciolariidae), $2=\mathrm{com}$ até três cúspides secundarias (P. pusio, Buccinidae, Phrontis, Cyclope sp. B. laevissima) (IC: 50, RI: 84, L: 4). 


\subsection{Sistema reprodutor}

\subsubsection{Feminino}

97. Oviduto palial, abertura genital feminina: $0=\mathrm{em}$ forma de fenda, $1=\mathrm{em}$ forma de poro (Buccinoidea exceto B. undatum, Phrontis, N. coronatus, H. corticata, D. abbreviata) (IC: 16, RI: 54, L: 6).

98. Bursa copulatrix: $0=$ ausente, $1=$ presente $(R$. morrisoni, $P$. tupiniquim, Buccinanopsinae, Phrontis, Cyclope sp., N. arcularia, H. reticulata, H. corticata, Bullia, E. inicinctus) (IC: 12, RI: 50, L:8) (acctran).

O oviduto palial é uma importante estrutura para análises comparativas, mas, aparentemente, é mais útil em nível especifico. Na maioria dos nassarídeos o oviduto é uma estrutura simples, tubular e glandular.

A presença de estruturas anexas, como, por exemplo, a bursa copulatrix só está presente nos primeiros táxons da família Nassariidae. A partir do nó 13, essa estrutura volta a desaparecer e se mantém por todos os táxons até o final da topologia.

99. Oviduto visceral: $0=$ reto, $1=$ sinuoso $(T$. laevigata, $V$. cassiforme, $P$. tupiniquim, B. undatum, B. gradatus, Phrontis, H. pulla, H. luteostoma, Bullia group, D. abbreviata, E. unicinctus) (IC: 11, RI: 38, L: 9) (acctran).

O oviduto visceral é responsável por transportar os óvulos das gônodas para o oviduto palial, é uma estrutura tubular, bem fina, ventral ao rim. Foi possível visualizar duas configurações acima exploradas para essa estrutura.

O caráter é bastante diluído por toda a topologia, o estado 1 surge como convergência sinapomórfica para os nós $8,17,29$, contudo, filogeneticamente esse caráter une o gênero Phrontis.

\subsubsection{Masculino}

100. Comprimento do pênis em relação ao animal: $0=$ curto (até a metade), $1=$ longo (maior que a metade) (IC: 25, RI: 66, L: 4).

O pênis é uma estrutura copuladora que auxilia na transferência do esperma. Nos Neogasropoda, situa-se, caracteristicamente, na massa cefalo-pediosa perto e posterior ao tentáculo direito do macho.

Apenas nos táxons mais basais de Buccinoidea o pênis se manteve curto, a partir do nó 10, todos os animais apresentam o estado derivado deste caráter.

101. Presença de papila no pênis: $0=$ ausente, $1=$ presente $(T$. laevigata, $P$. aurantiaca, P. tupiniquim, Buccinidae, B. gradatus, D. miran, D. abbreviata, E. unicinctus) (14, RI: 25, L:7) (acctran). 
102. Forma do pênis: $0=$ cilíndrico, $1=$ achatado dorso ventralmente $(P$. aurantiaca, $F$. frenguelli, $R$. morrisoni, a partir do nó 16) (IC: 25, RI: 76, L: 4).

103. Penis carinado: $0=$ ausente, $1=$ presente $(P$. aurantiaca, Phrontis alba, $H$. corticata, H. olivacea, B. laevissima) (IC: 25, RI: 40, L: 4) (acctran).

\subsection{Sistema nervoso central}

104. Gânglio bucal: $0=$ separado do anel nervoso, $1=$ fundido ao anel nervoso (Fasciolariidae, T. roboreus) (IC: 50, RI: 75, L: 2).

Os gânglios bucais são bastante notáveis em Caenogastropoda, geralmente, estão localizados logo posteriormente à massa bucal e, possivelmente, coordenam a movimentação dessa estrutura. O par de gânglios são ligados entre si através de um nervo conectivo. Em Neogastropoda houve a proximidade desses gânglios ao anel nervoso.

Nos fasciolariideos essa característica se intensifica, e além, dos gânglios estarem próximos ao anel nervoso, eles se fundiram ao gânglio pedal.

105. Comissura cerebral: $0=$ ausente, $1=$ presente $(N$. scabriusculus, D. miran, Bullia, E. unicinctus) (IC: 50, RI: 75, L: 2).

Devido a condição hipoatróide do anel nervoso dos neogastropoda, a separação entre os gânglios não é clara, na verdade, é praticatimamente invisível. No entando, em alguns táxons mais derivados dentro de Nassariidae é possível visualizar a comissura cérebro-pleural, que forma uma espécie de "alça" posterior no anel nervoso. 


\section{Análise Cladística}

Tabela II. Matriz dos caracters. Os táxons listados estão organizados na primeira coluna (os grupos externos estão representados nas 14 linhas anteriores) e o numero dos caracters na primeira linha de cada coluna. O símbolo “_“ significa que o caráter não é aplicável; “?” indica que o caráter não pode ser examinado.

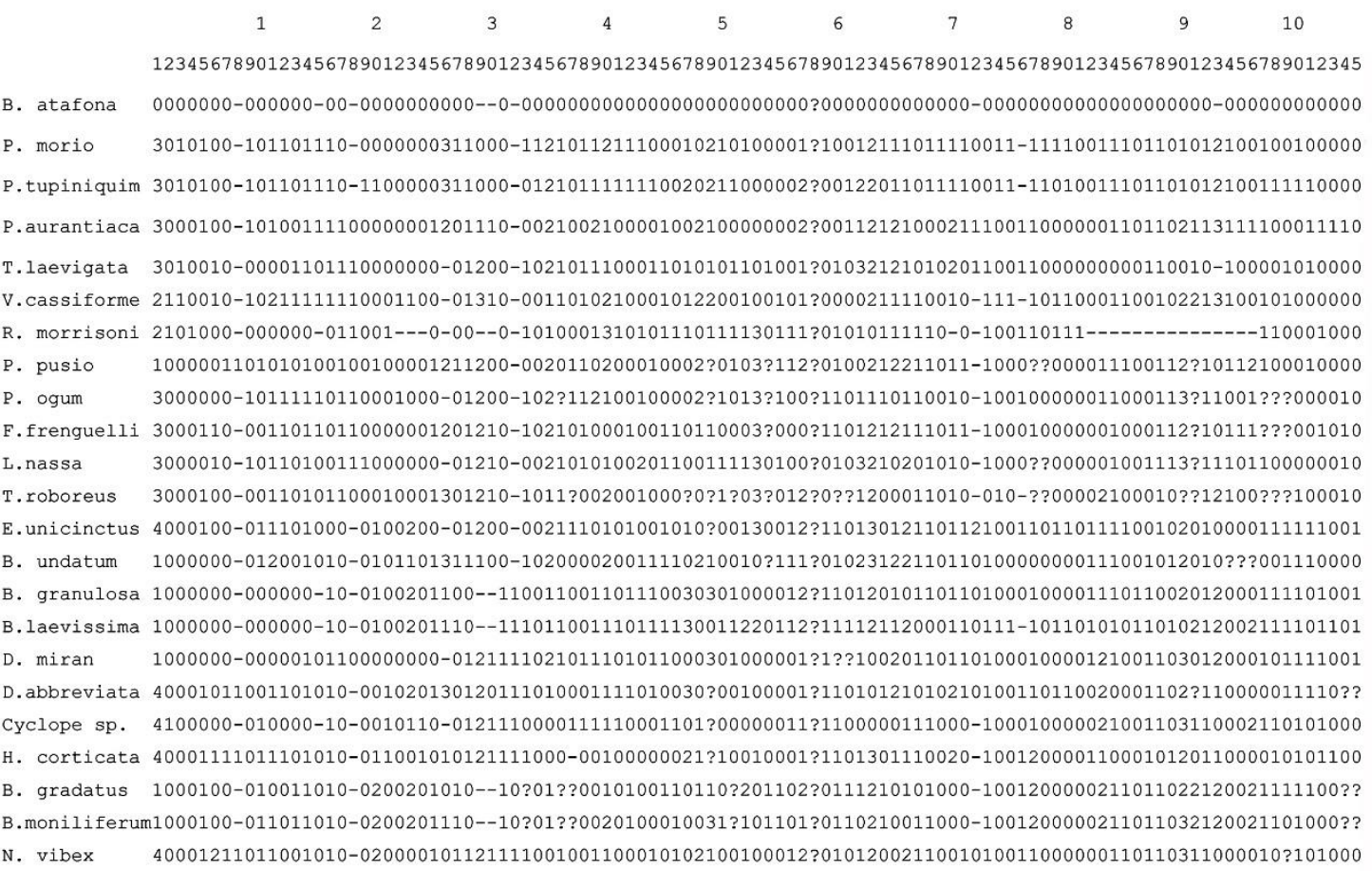

\section{Tabela II. Continuação}

$\begin{array}{ccccccccc}1 & 2 & 3 & 4 & 5 & 6 & 7 & 8 & 9\end{array}$ N.polygonatus 40001210011101000-020000101121111001001100010102100100012?0101200211001010011000000110110311000010?101000 N.arcularius 40001211011001010-000021101121111000101101001130101000012?11013001110110100110000001001103110000110100000 N. scabriusculus 40001211011001010-000021111120110010000100010130?01000012?1001200111010-100110000021001103111000???101001 P. alba sp.1 40001110011101010-011021100121111020010210010002100100012?0101200111020-100000000021000103212002010????00 P. alba sp.2 40001110011101010-011021100121111020010210010002100100012?0101200111020-100000000021000103212002010????00 P. alba sp.3 40000111011001000-0110010-0120111010001211201101100000111?1011000111010-100110000000010003211002011101100

P. alba sp.4 4000100-011001000-011001110121111000101211200001?00100111?0101010110011-100100000021011112213002110100000 P. alba sp.5 40001111011101000-0110210-0120110000010200101102?00030112?1001201111010-100110110021001102211002011001000

P. alba sp.6 40000110011101010-0110010-1120111010000111001012100000103?1113010111010-10010000002000010201100201?1010??

N. coronatus 4000100-010101010-010021110121111010111201001010?01100012?1101002111020-100120000021001103011000000101000

H. luteostoma $40000211011101010-000001120120111000001101011001 ? 01000001 ? 0103112211010-100100000120001112210000101101000$ H. pulla 40000211011101010-0000200-0121111000000110001001100100103?1113310100010-1001100001110011032110??101101000

H. olivacea 40000110010101010-000000120120111020110200000110111?30001?0003102211010-111-20000100001103010000???101100 H.reticulata 4000010-011101010-000020110121110010001101111111?11130001?11031101110?10100100000020011111212000110????00 N.paucicostatus $4000100-001101000-01$ ???????????????????????????????????????????????????????????????????????????? H.incrassata 400?1011011101000-011021110121111011011111100021101000110?1111100110010-100100000011000102110???011????00 
Tabela III. Fragmento da matriz dos caracteres retirada de Simone (2011) "Phylogeny of the Caenogastropoda (Mollusca), based on comparative morphology", contendo todos caráteres e a inserção dos táxons aqui analisados. Os táxons listados estão organizados na primeira coluna e o numero dos caracteres na primeira linha de cada coluna. O símbolo “_“ significa que o caráter não é aplicável; “?” indica que o caráter não pode ser examinado.
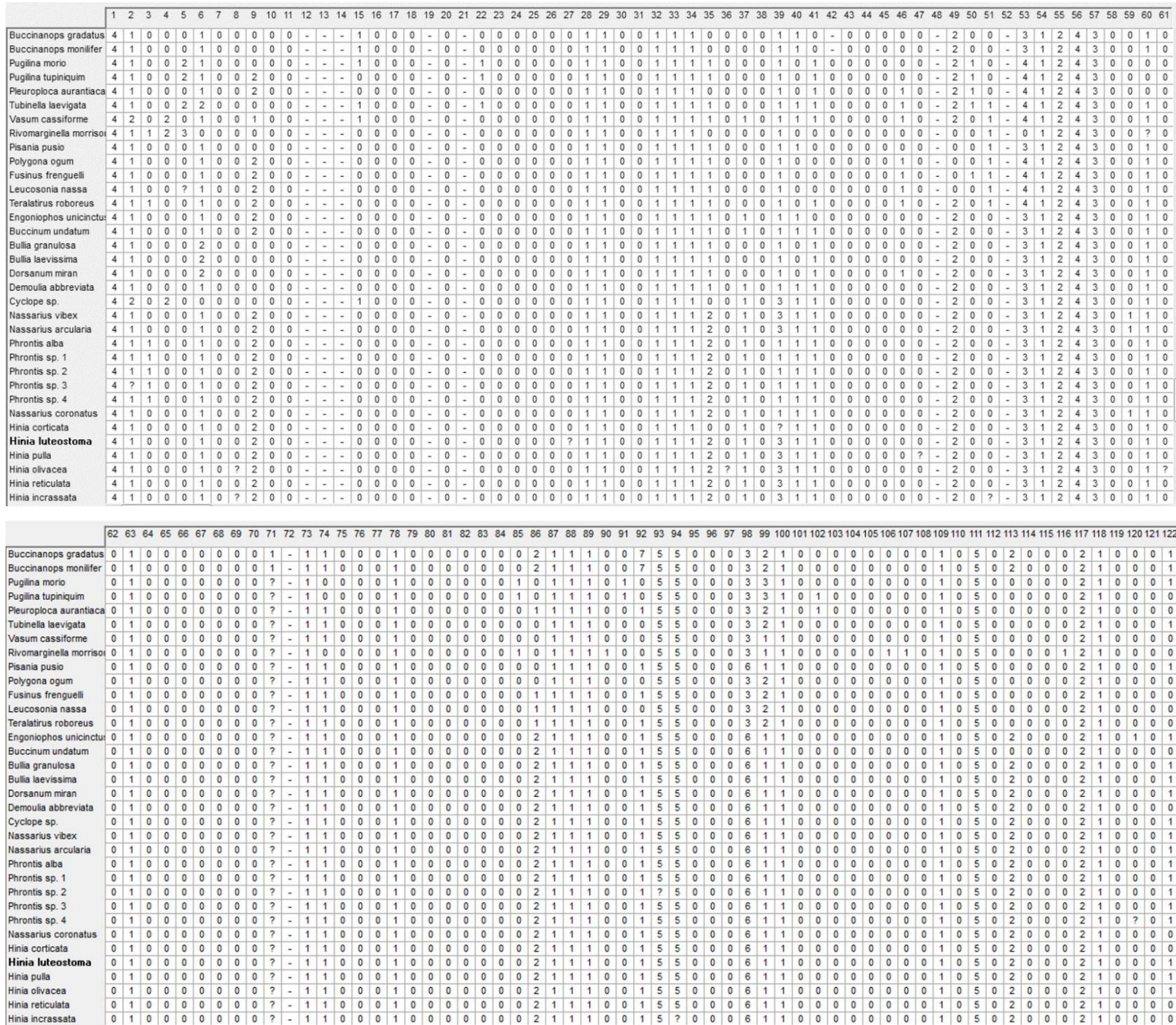


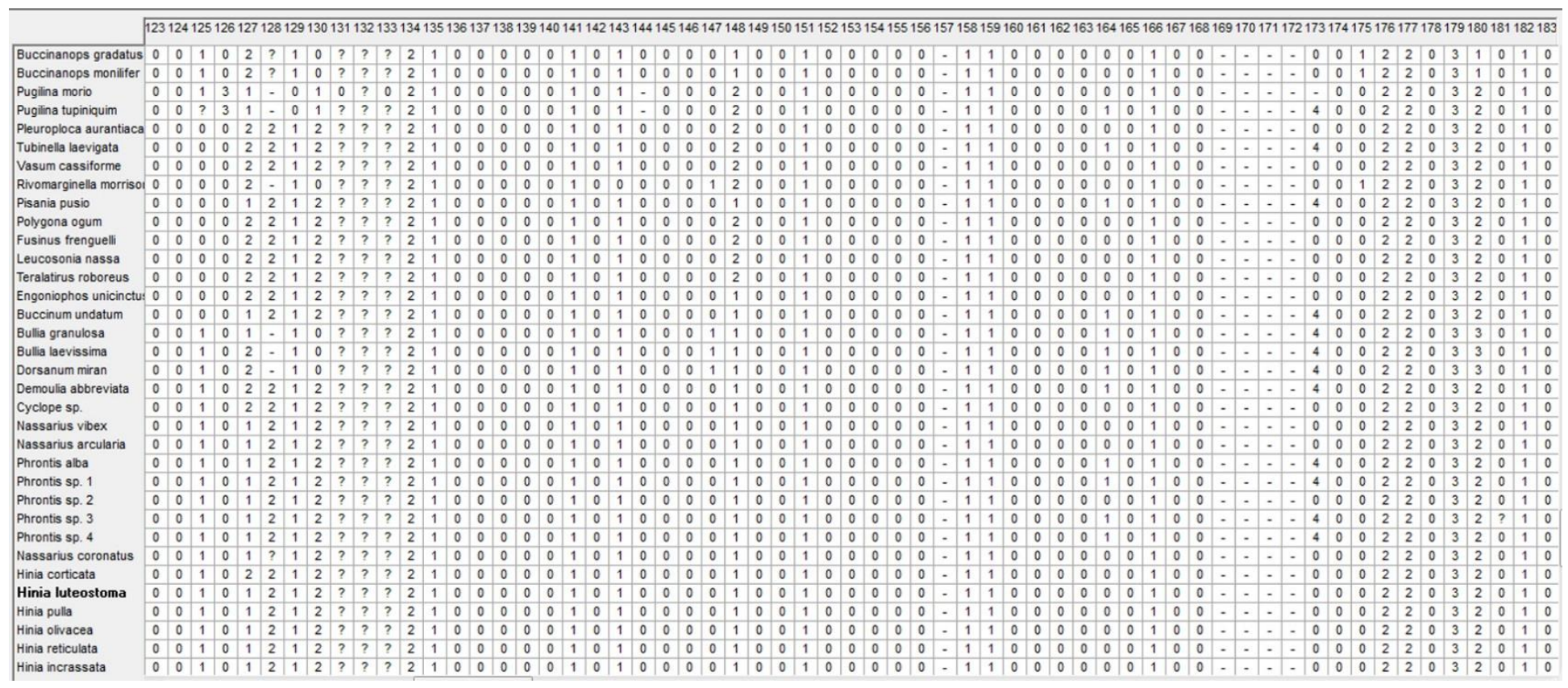

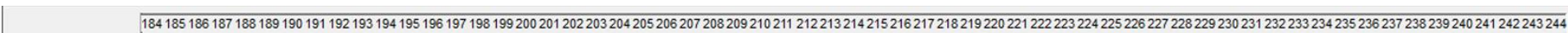

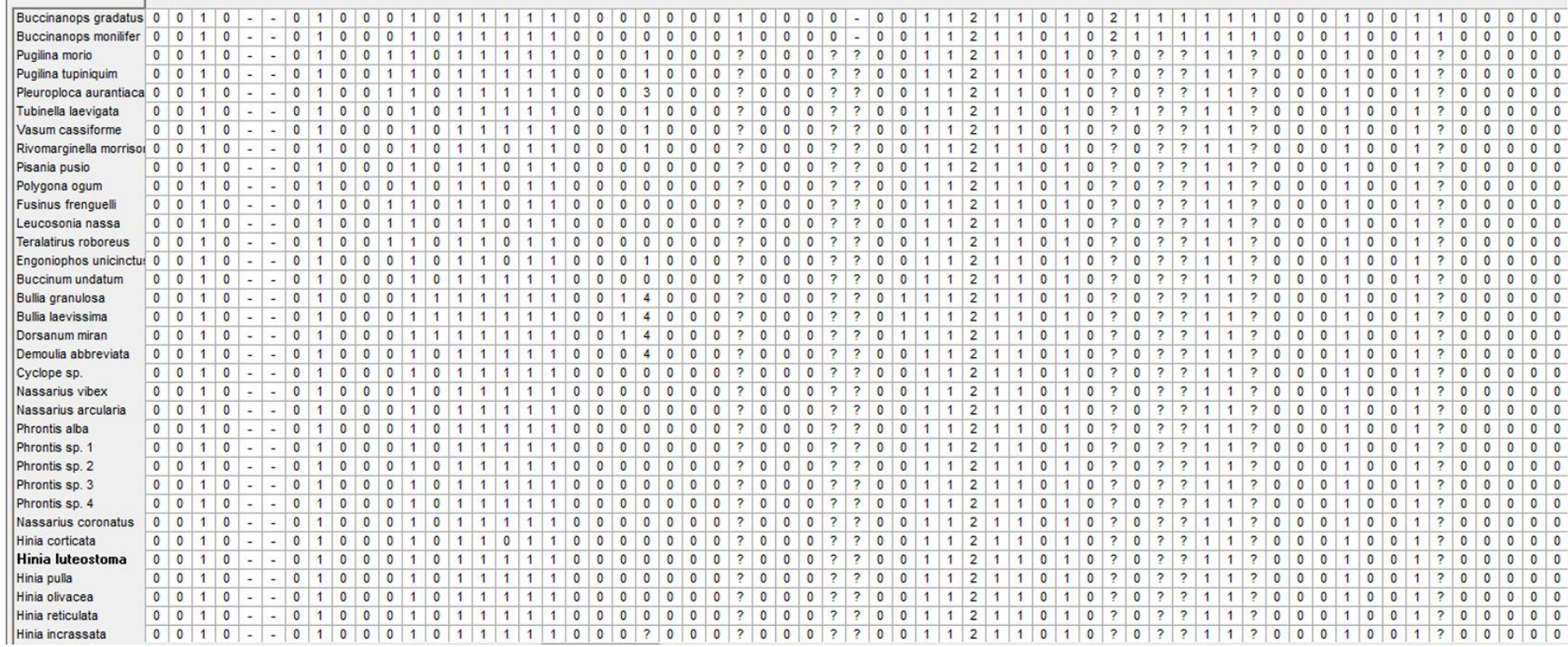




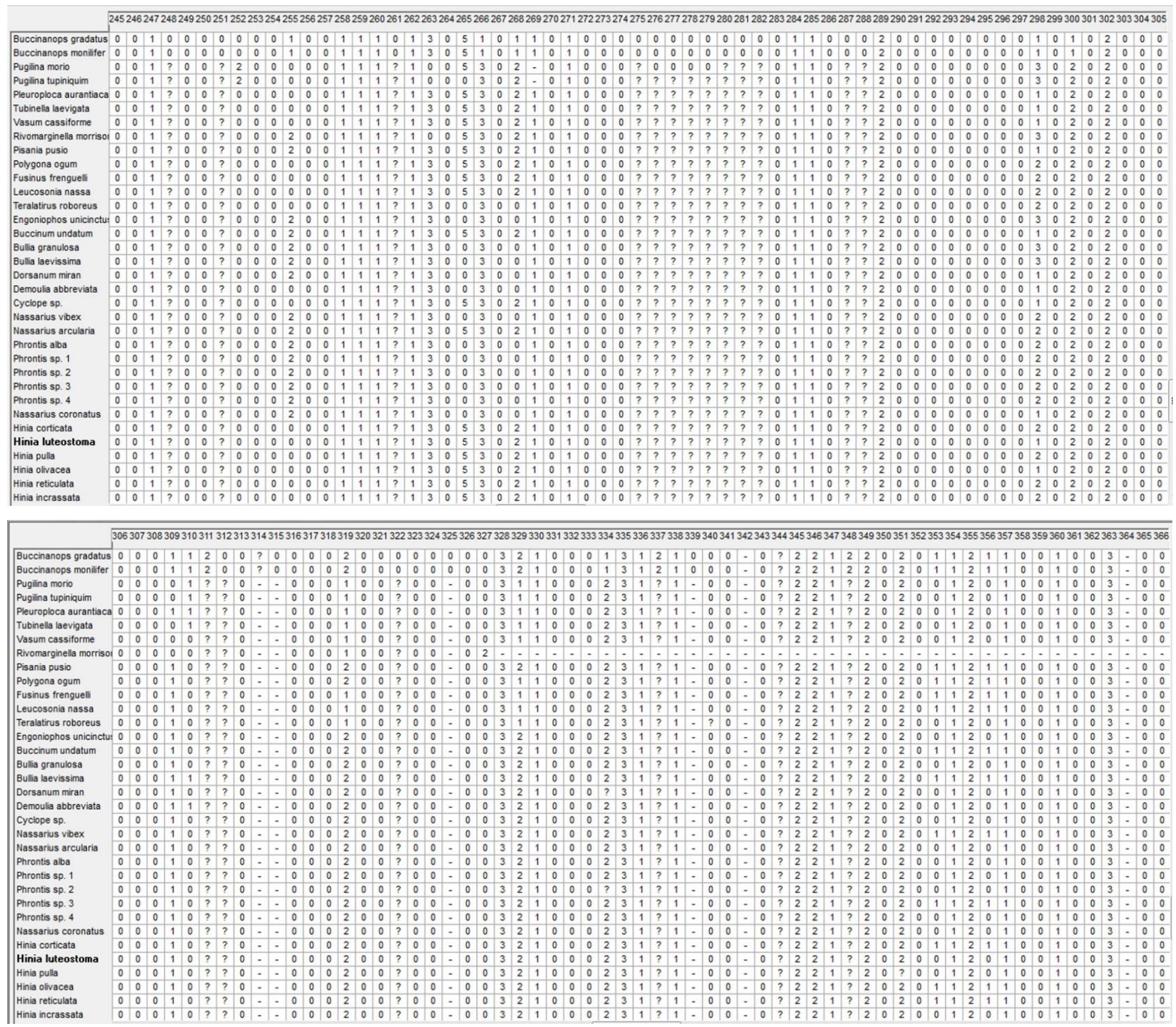



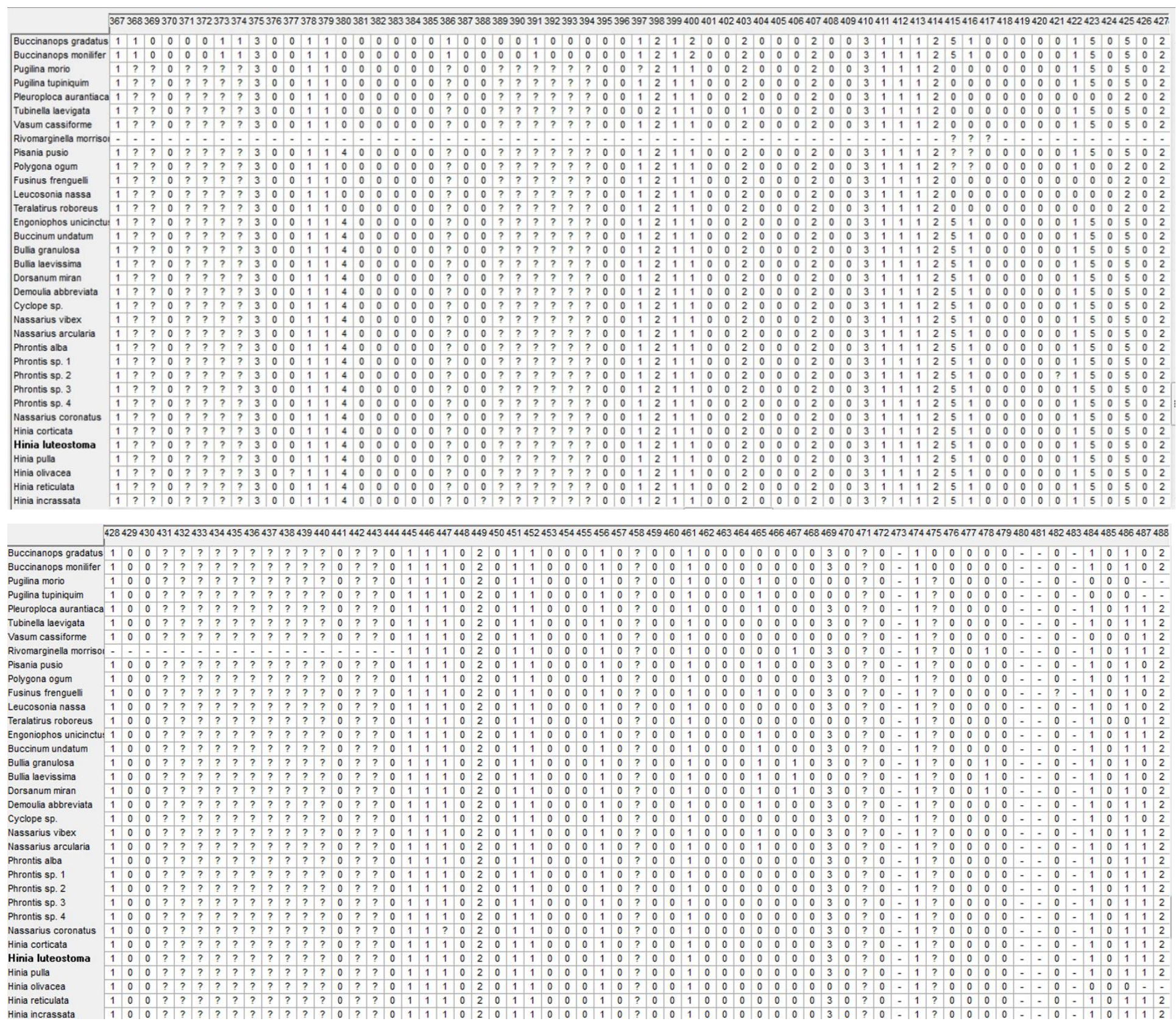


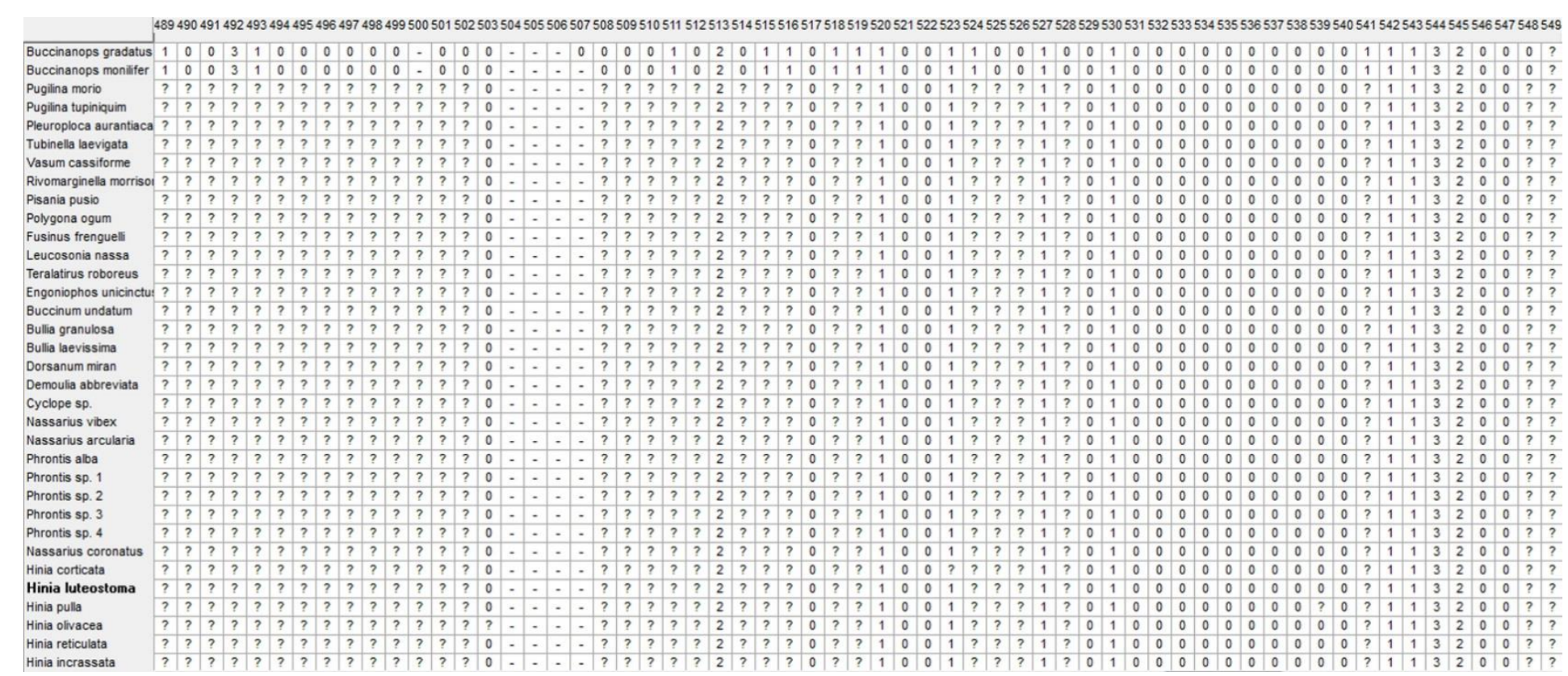

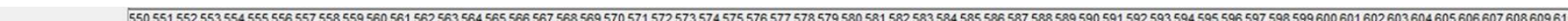
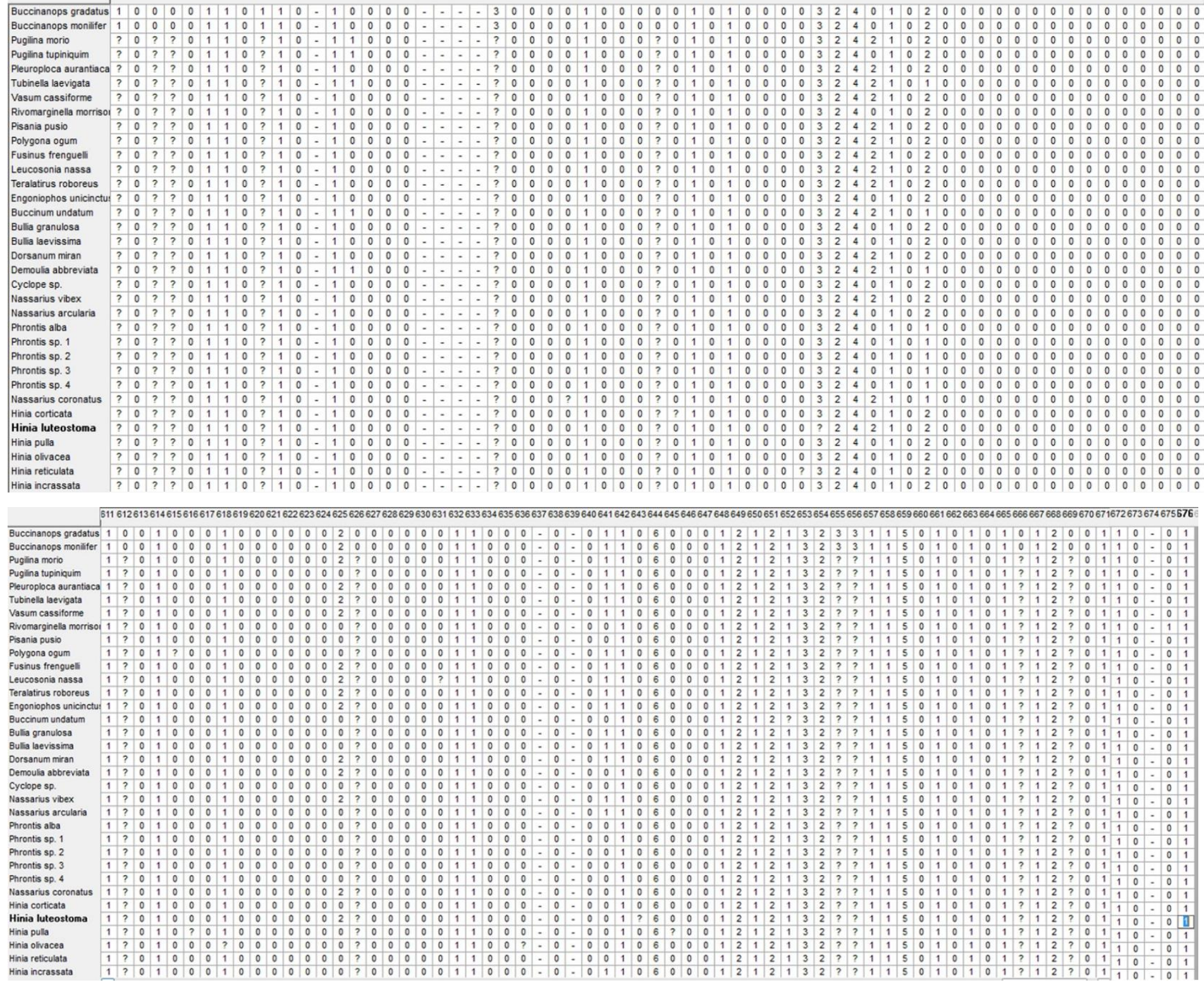


\section{Análise do Cladograma}

Abaixo estão apresentados cinco cladogramas, o primeiro referente a árvore de pesagem implícita (Fig. 318), com todos os caracteres plotados (na região superior) e os estados para cada caráter (abaixo). Cada sinapomorfia está representada com as marcas preenchidas $(\bullet)$ e as transformações homoplásticas pelas marcas vazias $(\circ)$. O segundo cladograma (Fig. 319) apresenta os principais nós numerados. O terceiro cladograma (Fig. 320) exibe todos os nós numerados. O quarto (Fig. 321), corresponde a árvore de consenso estrito e o quinto (Fig. 322), por fim, o cladograma de Simone (2011) com a inserção dos 36 táxons aqui analisados, representados pela topologia em destaque. 


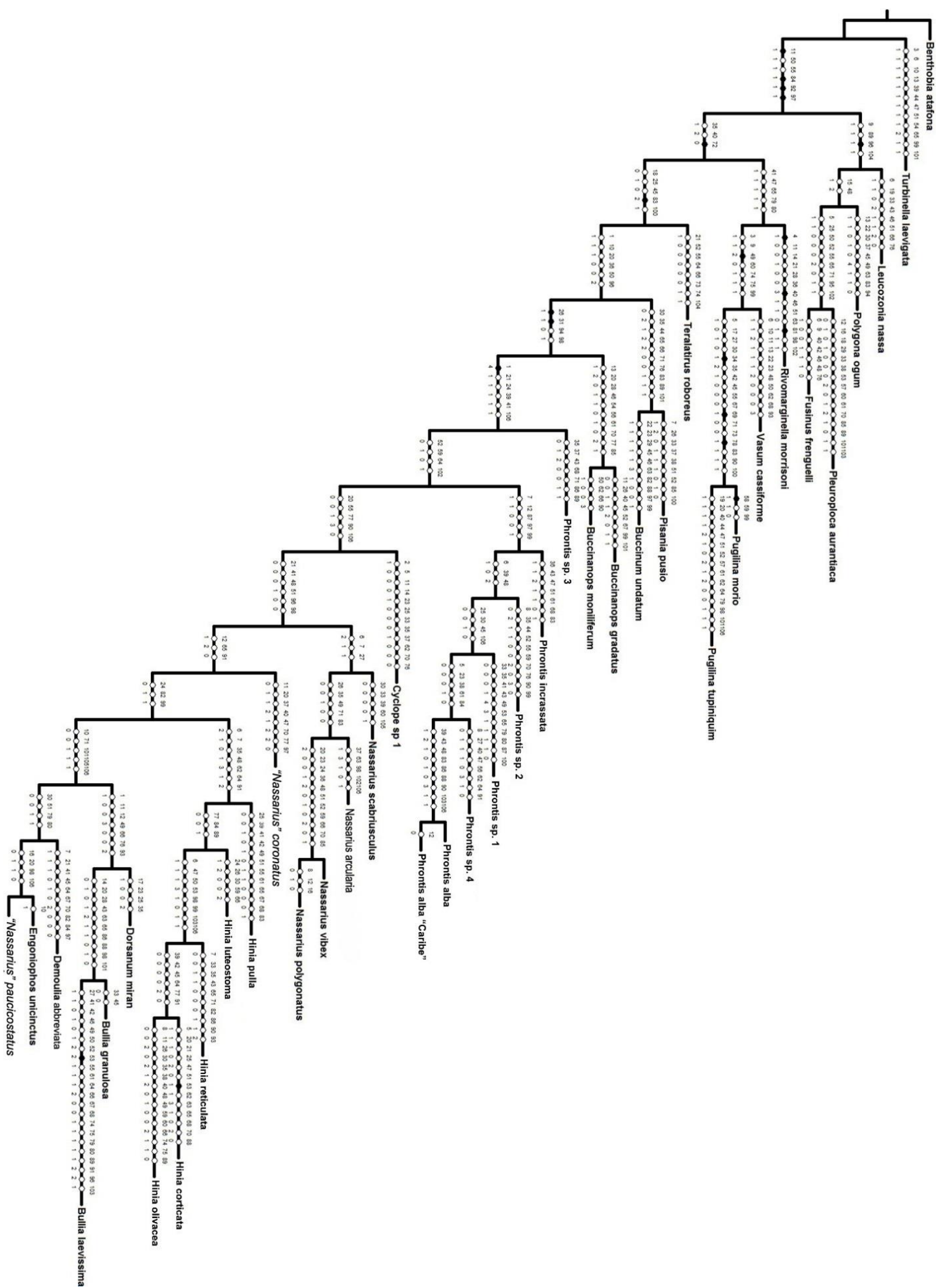

Fig. 318: Árvore mais parcimoniosa obtida através da pesagem implícita, com valor de K: 6,48375. Sinapomorfias de cada nó indicadas. O número acima de cada símbolo indica o cárater, e o abaixo o estado. L: 743; IC: 20: IR: 44. 


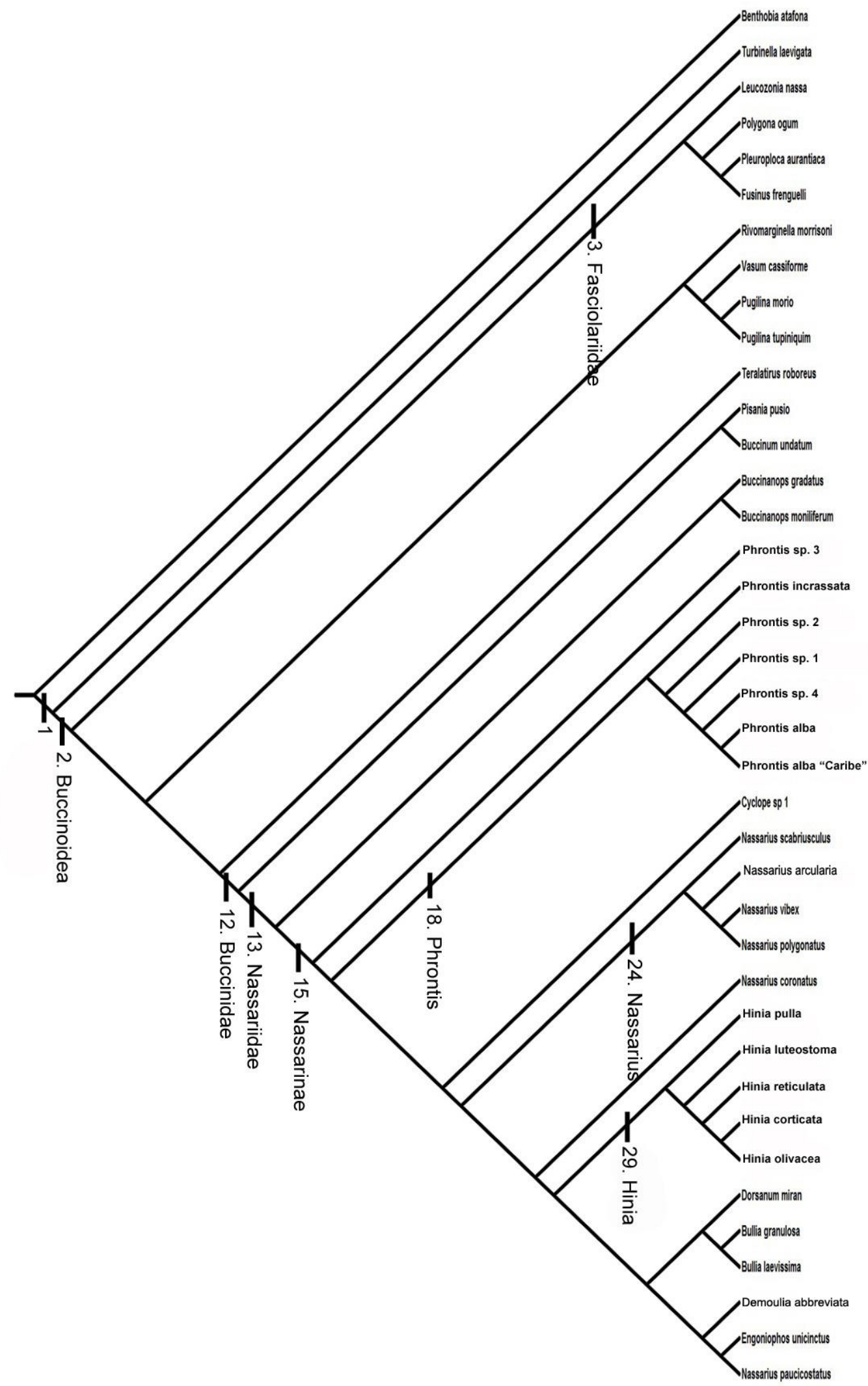

Fig. 319: Árvore obtida através da pesagem implícita, com principais nós nomeados: Buccinoidea (2); Fasciolariidae (3); Buccinidae (12); Nassariidae (13); Nassariinae (15); Phrontis (18); Nassarius (24); Hinia (29). 


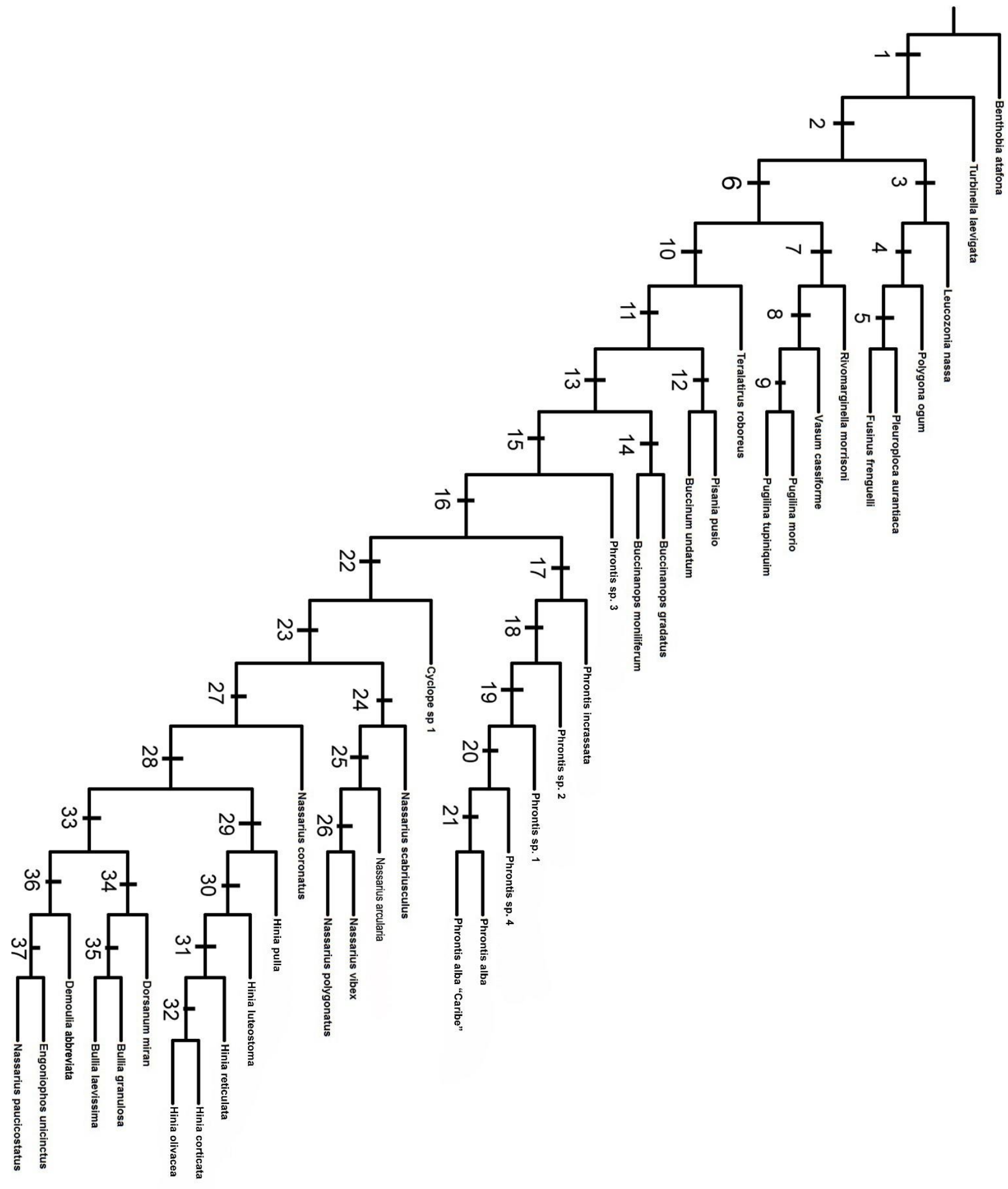

Fig. 320: Árvore mais parcimoniosa obtida da pesagem implícita, com valor de K: 6,484375. Número de cada nó indicado. L: 743; IC: 20; IR: 44. 


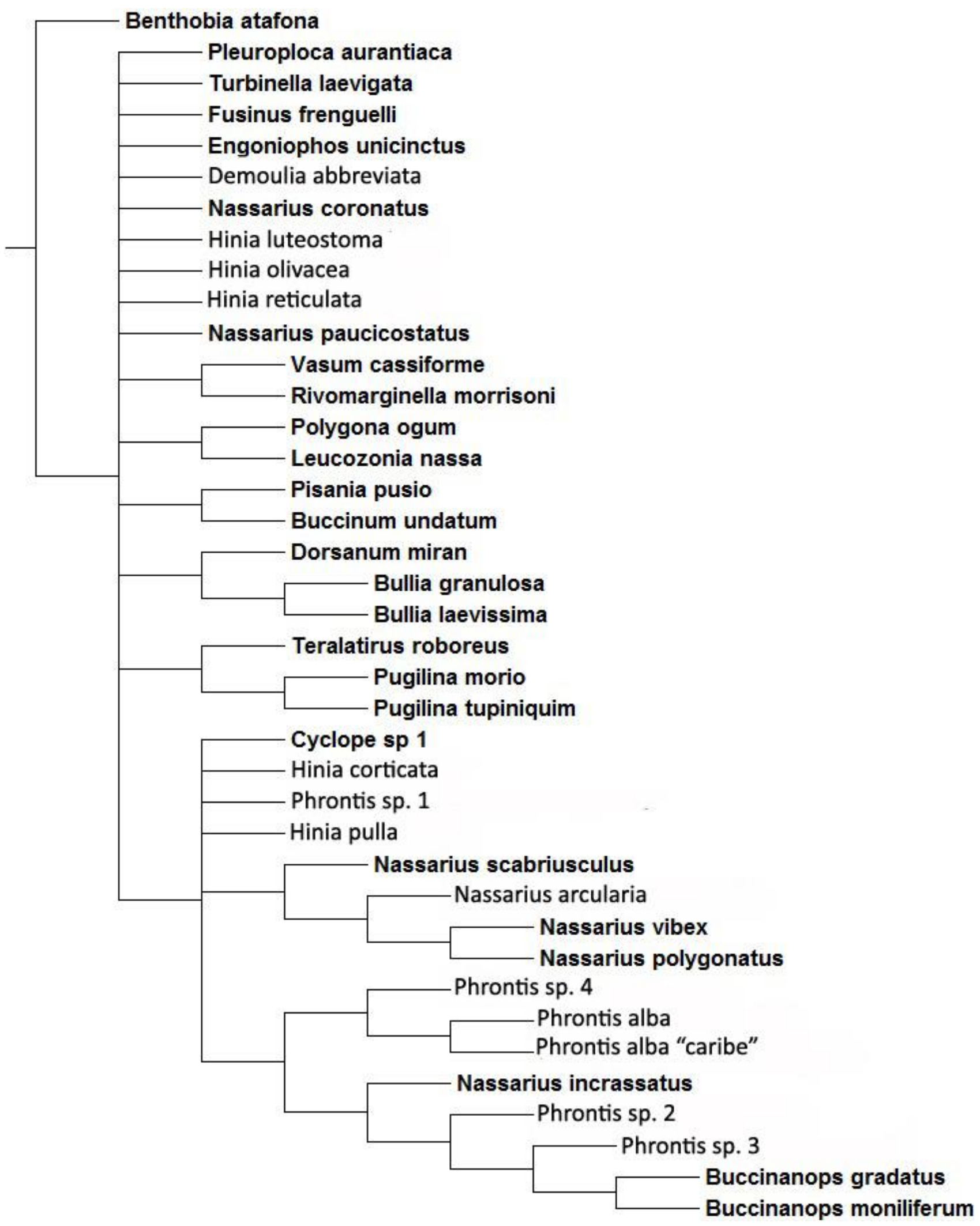

Fig. 321: Cladograma de consenso estrito. Obtido através de 21 árvores mais parcimoniosas; L: 880; IC: 16; IR: 32. 


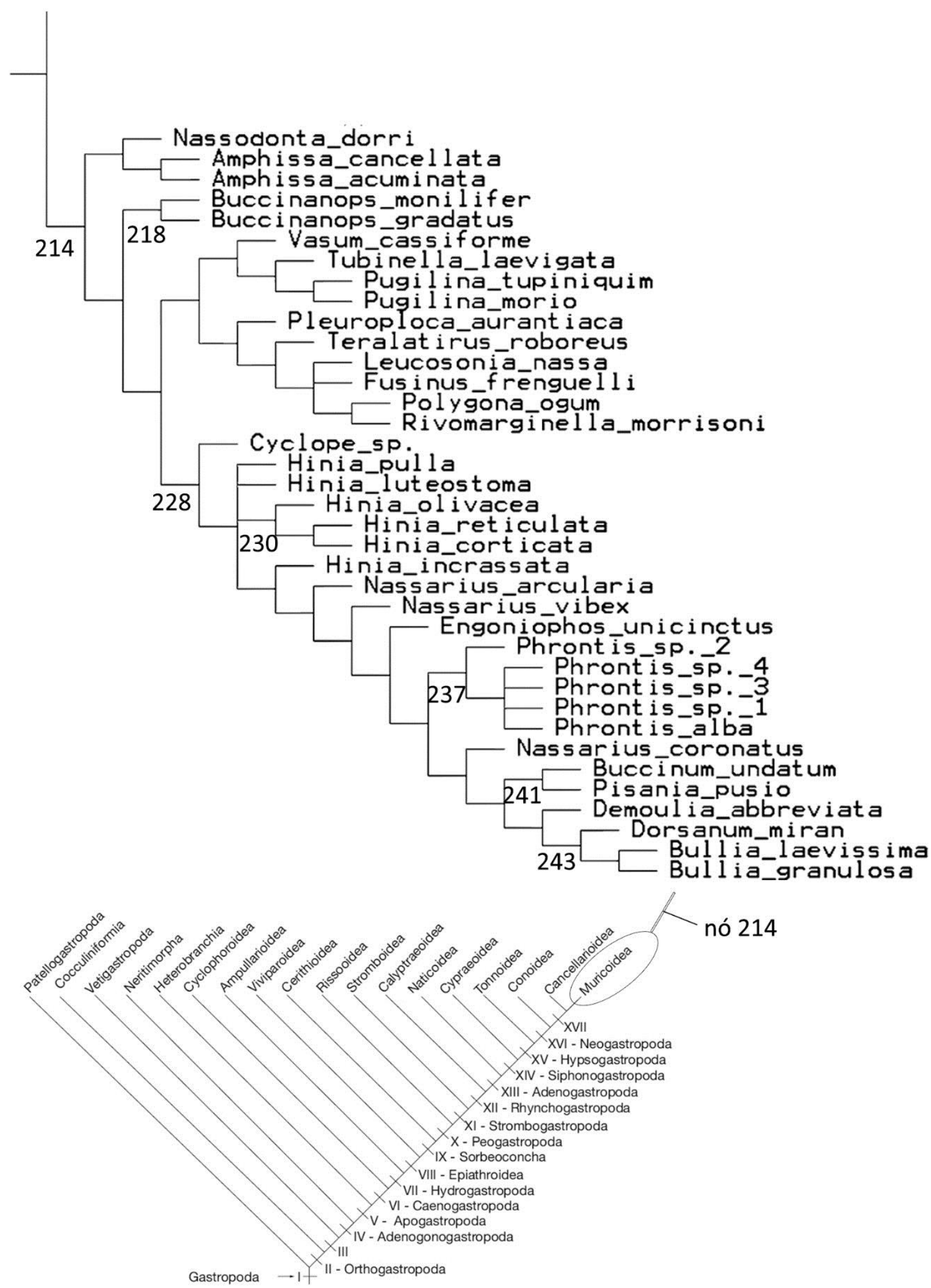

Fig. 322: Árvore de consenso, obtida através de 40 árvores mais parcimoniosas, resultante da inserção na matriz de Simone (2011). Número do nó onde resultou a inserção e principais nós indicados. L: 3300; IC: 47; IR: 94. 


\section{Apresentação e discussão dos clados.}

O grupo externo está representado entre os nós 1-12, já o grupo interno encontrase representado a partir do nó 13.

O nó 1 engloba todos as espécies da análise, exceto aquela selicionada para o enraizamento que representa uma superfamília, que, de fato, é mais distante dos demais. O nó 1 não foi nomeado nesta análise, no entanto, este clado pode ser considerado como a superfamília Muricoidea proposta por Ponder, 1973, porém essa classificação não foi adotada neste trabalho.

O nó 2 representa a superfamília, já conhecida na literatura, Buccinoidea como definida por Kantor $(1996,2002)$. Este nó se mostrou bastante estável já que é suportado por seis sinapomorfias e apenas duas delas são homoplásticas. Dentre as sinapomorfias do nó, as mais conspícuas são: a presença do musculo m2a e o surgimento de cartilagens fundidas, ambas características do odontóforo, carateres 84 e 92 respectivamente.

O nó 3 reune os Fasciolariidae utilizados na análise, a família é suportada por 4 sinapomorfias, sendo que a presença do dente radular lateral multicuspidado é exclusiva para a família. Esse clado se subdivide em mais dois nós, 4 e 5, o primeiro não nomeado, mas que exclui Leucozonia nassa das demais, e o segundo que pode ser representado pela subfamília Fusininae reunindo Pleuroploca aurantiaca e Fusinus frenguelli.

O nó 6 agrupa o outro grande clado de Buccinoiidea e reúne todas as demais famílias da análise que não Fasciolariidae, é suportado por três sinapomorfias sendo apenas uma delas exclusiva: a presença de duas pregas no esôfago anterior.

O nó 7 é suportado por cinco sinapomorfias homoplásticas; reúne Rivomerginella morrisoni, um dos poucos Neogastropoda de água doce conhecidos, às espécies do gênero Pugilina agrupadas pelo nó 9 e Vasum cassiforme que aparece, surpreendentemente, como grupo irmão das pugilinas (nó 8) e não de Turbinella laevigata, contrariando, assim, a classificação atual que loca essas duas espécies na família Turbinellidae.

O nó 10 é suportado por cinco sinapomorfias e engloba nassarídeos, bucinídeos e Teralatirus roboreus, comumente classificada como um fasciolarídeo, mas que nessa análise resultou como sendo grupo irmão da família Buccinidae. Das sinapomorfias, as de grande destaque são: a presença de cabeça protuberante, que reverteu nas espécies contidas no gênero Phrontis, e a presença de um único feixe para o musculo do 
odontóforo, m2, característica essa não homoplástica e que se mantém por toda topologia restante.

O nó 11 é, sem sombra de dúvida, o mais importante nesta análise, pois reúne as famílias Buccinidae e Nassariidae e corrobora com sua proximidade. É suportado por seis sinapomorfias, sendo as de maior destaque: a presença do espessamento da borda do lábio externo da concha, característico para essas duas famílias, ausência de glândula de cimento e a presença de cúspides secundarias no dente radular lateral.

A monofilia da família Buccinidae é confirmada nesta análise, assim como sua posição de grupo irmão da familia Nassariidae. A família é representada no nó 12 é e sustentada por 10 sinapomorfias, todas homoplásticas e compartilhadas com determinados nassariideos. Sendo possível, até, se identificar claros casos de homologias entre elas, como por exemplo, a presença do dente parietal (caráter 7).

O nó 13 abrange os animais alvo do presente estudo, a família Nassariidae, o táxon é sustentado por quatro sinapomorfias: tentáculos cefálicos duas vezes maiores que a cabeça, presença de tentáculos epipodiais, dente radular raquidiano multicuspidado e ausência de bursa copulatrix no oviduto palial das fêmeas. Embora pareça pouco, essas características podem ser consideradas diagnósticas para a família, pois, mesmo com certo grau de variação, esses atributos são compartilhados por todas as espécies estudadas da família.

No resultado desta análise, a melhor forma de se dividir a família é em apenas duas subfamílias, Buccinanopsinae e Nassariinae, nós 14 e 15 respectivamente, diferindo das classificações citadas acima, que propõem um número maior de subfamílias para a família (e.g., Haasl, 2000; Lee Ann, 2016). A subfamília Buccinanopsinae é sustentada por 10 sinapomorfias, as de maior destaque são: ausência de olhos, presença de glândula anal e presença do musculo m2b no odontóforo. É interessante notar que esta análise corrobora com a criação desta subfamília, proposta por Lee Ann (2016), afim de alocar o gênero Buccinanops, uma vez que a sua posição comumente oscila entre as famílias Nassariidae e Buccinidae.

Como dito anteriormente o nó 15 corresponde a subfamília Nassariinae, é suportado por 5 sinapomorfias entre as mais importantes estão o apareceimento da forma oval nas conchas (caráter 1) e a presença de expansões em forma de espinhos no opérculo. Esses atributos se mantém por todos os animais da topologia restante.

O nó 16 é suportado por quatro sinapomorfias e dividi-se em dois outros clados, o primeiro, com cinco sinapomorfias, entre elas: presença do dente parietal e abertura 
genital em forma de fenda, que sustentam o gênero Phrontis e o segundo com quatro sinapomorfias, e que sustenta os demais gêneros incluídos na analise, nós 17 e 22 respectivamente.

Os nós 18 a 21 reportam-se aos subgrubos internos do gênero Phrontis. Esta análise revelou que todas as espécies estudadas, que outrora eram identificadas como Nassarius albus, realmente são entidades distintas. A filogenia revelou a proximidade das espécies que ocorrem em ilhas, assim como também, mostrou essa relação nas espécies continentais.

O nó 24 agrupa o gênero Nassarius "stricto sensu", incluindo a espécie tipo, Nassarius arcularia. É suportado por três sinapomorfias: presença de um escudo parietal bastante desenvolvido excendendo em aproximadamente $50 \%$ do tamanho da abertura, presença de dente parietal e tentáculos próximos entre si. A validade do gênero Nassarius já foi contestada por alguns autores, e.g., Lee Ann (2016). De fato, todas as sinapomorfias apontadas acima são homoplásticas, convergindo com outros gêneros da família. No entanto, neste trabalho a monofilia do gênero é confirmada, apoiada na posição topológica da espécie tipo e levando em consideração os novos arranjos genéricos aplicados a família.

O nó 29 reúne as espécies contidas no gênero Hinia, o nó é sustentado por sete sinapomorfias, destas, duas são compartilhadas com o gênero Nassarius, o grande desenvolvimento do escudo parietal e a presença do dente parietal. Mesmo com essa semelhança morfológica o gênero foi mantido apoiado na presença da espécie tipo Hinia reticulata no clado. Isso resultou em uma taxonomia reformulada para o gênero, discutida a seguir.

O nó 34 é referente ao táxon conhecido por “Bullia group” proposto por Allmon (1990), e abrange as espécies Dorsanum miran, Bullia granulosa e Bullia laevissima. É sustentado por sete sinapomorfias, as de maior destaque são: o aspecto de domo da concha, ausência de esculturação na concha e a presença de apenas um par de músculos retratores da probóscide. Essas espécies são, comumente, alocadas na subfamília Bullinae, no entando nesta análise esse grupo resultou como sendo parte integrante da subfamília Nassariinae, o que levou à criação da tribo Bullini.

O nó 36 reúne “Nassarius” paucicostatus e Engoniophos unicinctus, outrora já classificado como um Buccinidae (e.g., Abbott, 1974). É interessante destacar que nessa análise esta espécie resultou como um nassarídeo corroborando com algumas filogenias e classificações atuais (e.g., Lee Ann, 2016; Bouchet, 2015), embora, dentre outras 
características, E. unicinctus careça de tentáculo epipodial, como visto em nassarídeos típicos, porém apresemtam espanções semelhantes a tentáculos localizadas na borda anterior do pé. O clado é sustentado três sinapomorfias dentre elas a ausência do canal anal é a de maior destaque.

Em relação a árvore de consenso estrito (Fig. 321), resultante de 21 árvores igualmente parcimoniosas, 18 nós foram colapsados, o que resultou na não confirmação da monofilia da família Nassariidae, assim como dos fasciolarídeos. A primeira, das duas polimitomias, agrupa espécies das famílias Turbinelidae, Fasciolaiidae e Nassariidae, desta os gêneros Demoulia, Engoniophos e Hinia estão presentes.

A segunda politomia ocorre exclusivamente com gêneros de Nassariidae, Hinia, Phrontis e Cyclope. Apesar desse resultado, de fato, refutar a monofilia dos nassarídeos, alguns grupos se mantiveram como clados naturais. Entre eles: o clado "Bullia group”e o gênero Nassarius, novamente se restringido a algumas espécies relacionadas a espécietipo. Assim como acontece com o gênero Phrontis que só teria validade taxonômica se restringir-se à espécie-tipo Phrontis alba proveniente da Flórida e Phrontis sp. 4 proveniente da Ilha da Trindade. A subfamília Buccinanopsinae também se manteve agrupada e reúne as espécies analisadas do gênero Buccinanops.

Essa proposta reformularia toda a taxonomia de Nassariidae, inclusive desses clados citados acima, que só poderiam ser validados se fossem recombinados em outros níveis hierárquicos, mudando, até, de famílias. Levando-se isso em consederação, optouse por adotar a topologia proposta pela árvore de pesagem implícita (Fig. 318).

A análise da inclusão dos nassarídeos na matriz de Simone (2011), resultou em 40 árvores igualmente parcimoniosas. O elenco das espécies analisadas aparece inserido, como era de se esperar, na ordem Neogastropoda, radicados na superfamília Muricoidea lato sensu de Ponder (1973), adotado por Simone (2011).

A árvore de consenso (Fig. 322) corrobora com a manofilia da família Nassariidae (nó 228), levando em consideração a exclusão do gênero Buccinanops (nó 218), que aparece como grupo irmão do clado que agrupa as famílias, Turbineliidae, Fasciolariidae e Nassariidae. No entanto, o arranjo interno de Nassariidae é todo reformulado, o gênero Nassarius resulta como um táxon parafilético, e suas espécies, embora estejam próximas, resultam em táxons independentes por toda a topologia.

De acordo com essa proposta as tribos Cyclopini, Hinini, Photini, Phrontini e Bullini voltam a serem consideradas subfamílias no estatus taxonômico da família. A subfamília Photinae resume-se a espécie Engoniophos unicinctus exclusivamente. 
O gênero Hinia (nó 230), se mantém como um clado natural apoiado na espécie tipo Hinia reticulata, contando com a recolocação das espécies Hinia pulla, Hinia luteostoma e Hinia incrassata em outro, ou outros gêneros.

As espécies analisadas do gênero Phronits surgem agrupadas no nó 237, corroborando com a validade taxonômica do gênero, ainda que, as relações internas entre essas espécies não sejam claramente definidas devido a politomia presente neste clado.

Os exemplares analisados da família Buccinidae, nesta hipótese, resultam como integrantes da família Nassariidae (nó 241), agrupados, na possível, subfamília Buccininae.

O conhecido "Bullia group" novamente aparece como um clado monofilético agrupando as espécies Bullia laevissima, Bullia granulosa e Dorsanum miran, o que reafirma a hipótese de que este clado, juntamente com o gênero Hinia, formam os agrupamentos mais consistentes, pois são presentes em todas as análises realizadas.

\section{Pós análise: Decisões taxonômicas finais.}

A família Nassariidae é um grupo monofilético no cladograma obtido por pesagem implícita (Fig. 320, clado 13). As subfamílias Buccinanopsinae e Nassariinae também formam agrupamentos monofiléticos, representadas pelos clados 14 e 15 respectivamente, e são as únicas subfamílias de Nassariidae.

A subfamília Buccinanopsinae, introduzida por Lee Ann (2016), foi corroborada nesta análise, alocando o gênero Buccinanops, outrora alocado na subfamília Dorsaninae (e.g., Haasl, 2000; Cernohorsky, 1984), que deixa de ser considerada como clado taxonômico nesta análise. Essa situação decorre devido ao posionamento da espécie Dorsanum miran como táxon irmão do gênero Bullia, e não como táxon irmão do gênero Buccinanops, como proposto por Adam \& Knudssen (1984). Esse novo arranjo dentro da subfamília Nassariinae, forma o grupo monofilético referente a nova tribo Bullini (clado 34) e reforça o conceito de "Bullia group" proposto por Allmon (1990).

O clado Nassariinae agrupa o gênero Phrontis (nó 17), de acordo com Lee Ann (2016) e Bouchet (2015) todos os animais classificados, até então, como Nassarius são relocados para este gênero. No presente estudo esse clado reúne as espécies pertencentes ao complexo "Nassarius albus" e a espécie "Nassarius incrassatus", reclassificada como Phrontis incrassata. É bom frisar que as espécies do "complexo N. albus" eram identificadas como uma única espécie, mas que se mostraram entidades distindas, com autapomorfias que sustentam sua individualidade especifica. Os Phrontis parecem ser 
endêmicos de cada localidade estudada, o que difere da ampla distribuição atribuída a Nassarius albus, que se estendia da Flórida ao Sul do Brasil (Abbott, 1974; Rios, 2009).

Primeiramente as espécies do "complexo N. albus" seriam recombinadas para o gênero Hinia, esta decisão seria tomada apoiando-se nas semelhanças, principalmente, conquiliológicas com as espécies atualmente classificadas neste gênero. No entanto, a posição da espécie tipo do gênero Hinia, Nassarius reticulatus, em outro agrupamento, obrigou algumas mudanças taxonômicas em ambos os clados (nós 17 e 29).

Para o clado 17, optou-se por combinar as espécies ali contidas para Phrontis, baseando-se nas características conquiliológicas deste gênero e na sinonímia do gênero Nassarius com Phrontis proposta por Gallindo et al. (2016).

Para o clado 29, então, a decisão seria de alocar as espécies ali contidas para o gênero Hebra, apoiando-se na posição topológica da espécie tipo Hebra corticata. Essa combinação não foi possível devido a presença de Nassarius reticulatus no clado, que é espécie tipo do gênero Hinia e descrita anteriormente a Hebra corticata. Portanto, suportado pela posição de $N$. reticulatus, todo o clado foi recombinado, para o então ressucitado, gênero Hinia.

Embora alguns autores, citados acima, contestem a monofilia do gênero Nassarius, nesta hipótese o clado resultou como um grupo monofilético, levando-se em consideração as novas combinações aplicadas nas espécies, que até então eram classificadas como Nassarius. O gênero é sustentado por três sinapomorfias e o clado é apoiado na presença da espécie tipo Nassarius arcularia.

A sinonímia entre Nassarius vibex e Nassarius polygonatus é plausível, baseada tanto no resultado desta análise quanto nos dados similares e sobrepostos da morfologia (nó 26). Com isso, conclui-se que $N$. vibex possui uma ampla distribuição que se estende desde a Carolina do Norte, E.U.A., até o sul do Brasil. O nó que respresenta a espécie é sustentado por 11 autapomorfias e está posicionada como espécie irmã de Nassarius arcularia, espécie-tipo do gênero. É importante ressaltar que esse conjunto de sinapomorfias somam à diagnose do gênero Nassarius.

O gênero Cyclope, embora, esteja alocado dentro da subfamília Nassariinae, resultou em um clado isolado após o nó 22, provavelmente, devido sua grande diferença conquiliológica dos demais nassarídeos o que levou na criação da nova tribo Cyclopini. A espécie que representa o gênero na análise apresenta 12 autapomorfias e é grupo irmão do clado que reúne os gêneros Nassarius, Hinia e a tribo Bullini, com o qual forma o clado 22 (Fig. 320), esse clado é sustentado por cinco sinapomorfias, todas homoplásticas. 
O clado 33 reúne as novas tribos Bullini, descorrida acima, e Photini que deixa de ser uma subfamília pertencente a Buccinidae, para uma tribo da subfamília Nassariinae, essa proposta é embasada na presença de Engoniophos unicinctus no clado. A tribo Photini também agrupa, a relocada espécie, Demoulia abbreviata,

Vale ressaltar que nenhuma das propostas taxonômicas aqui apresentadas, como o estabelecimento de novas sinonímias e combinações ou a definição de novos grupos, têm validade nomenclatural verdadeira. Essas propostas só passarão a ter validade a partir do momento em que esse trabalho for devidamente publicado nos termos do Artigo $8^{\circ}$ do Código de Nomenclatura Zoológica Internacional (ICZN, 1999).

\section{Resumo da taxonomia proposta para Nassariidae.}

De acordo com o presente resultado obtido da análise filogenética a família Nassariidae resultou em um táxon monofilético subdividido em duas subfamílias: Buccinanopsinae e Nassariinae. A primeira agrupa o gênero Buccinanops e a segunda os demais gêneros analisados: Nassarius, Phrontis, Cyclope, Demoulia, Engoniophos, Bullia, Hinia e Hebra.

As subfamílias Cylleninae e Dorsaninae, propostas por Shuto (1969), não foram corroboradas, enquanto que Bullinae e Photinae mudam de status hierárquicos e passam a ser as tribos de Nassariinae: Bullini e Photini, juntamente com Cyclopini, Nassarini, Hinini e Phrontini.

As espécies do "complexo N. albus" agora passam a pertencer ao gênero Phrontis. No entanto, o epíteto original - albus fica restrito a Phrontis alba com distribuição para Flórida e Caribe. As demais espécies do complexo, e de outras localidades, foram mantidas sem epíteto e suas descrições serão devidamente publicadas em revistas pertinentes.

O gênero Nassarius, com algumas recombinações, se manteve como um clado natural, assim como Cyclope, Demoulia, Dorsanum, e Bullia e suas respectivas espécies. O gênero Hebra se torna sinônimo junior de Hinia e Engoniophos é incluído, definitavamente, na família Nassariidae. 


\section{Conclusões}

1. Os dados anatômicos se mostraram eficientes para a construção e desenvolvimento da matriz de caracteres.

2. A familia Buccinidae parece ser grupo irmão de Nassariidae.

3. A monofilia da familia Nassariidae foi corroborada.

4. A monofilia da subfamilia Nassariinae foi corroborada.

5. As espécies analisadas do "complexo N. albus" são, de fato, entidades distintas. Essas espécies foram recombinadas para o gênero Phrontis. O epíteto "albus" é restrito a Phrontis alba com distribuição para Flórida e Caribe.

6. O gênero Hebra é sinonimo junior de Hinia.

7. O gênero Nassarius se restringido a determinadas espécies é um clado natural, e portanto, válido para taxonomia.

8. Nassarius polygonatus é sinonimo junior de Nassarius vibex.

9. As tribos Cyclopini, Bullini, Nassarini, Hiniini, Photini e Phrontini parecem ser clados mofiléticos.

10. A subfamilia Dorsaninae não e um clado natural.

11. O grupo conhecido como "Bullia group" foi confirmado, e inclui os gêneros Dorsanum e Bullia.

12. A tribo Photini é aqui criada e o gênero Engoniophos é confirmado como um Nassariidae. 


\section{Referências Bibliográficas}

Abbate, D., Simone, L. R. L., 2015. Review of Pugilina from the Atlantic, with description of a new species from Brazil (Neogastropoda, Melongenidae). African Invertebrates 56 (3): 559-577.

Abbott, R. T. 1974. American seashells; the marine Mollusca of the Atlantic and Pacific coasts of North America. Van Nostrand: Melbourne; 662 p..

Allmon, W. D., 1990. Review of the Bullia group (Gastropoda: Nassariidae) with comments on its evolution, biogeography, and phylogeny. Bull. Am. Paleontol. 99, 1179.

Arnold, W. H. 1965. A glossary of a thousand and one terms used in conchology. The Veliger 7: 1-50.

Bandel, K., 1984. The radulae of Caribbean and other Mesogastropoda and Neogastropoda. Zool. Verh. 214, 1-188.

Bieler R. 1992. Gastropod phylogeny and systematics. Annual Review of Ecology and Systematics 23: 311-338.

Brown, A.C. 1982. The biology of sandy-beach whelks of the genus Bullia (Nassariidae). Oceanography and Marine Biology, Annual Review 20: 309-361.

Bryan, G. W., Burt, G. R., Gibbs, P. E. and Pascoe, P. L. 1993. Nassarius reticulatus (Nassariidae: Gastropoda) as an indicator of tributyltin pollution before and after TBT restrictions. Journal of the Marine Biological Association of the United Kingdom, 73, pp 913-929.

Bouvier E. L. 1887. Syst eme nerveux, morphologie g'en'erale et classification des Gast'eropodes Prosobranches. Annales des Sciences Naturelle. Zoologie 7(3): 1-510.

Bouchet, P.; Gofas, S. 2015. Buccinoidea. In: Mollusca Base (2016). Accessed through: World Register of Marine Species at http://www.marinespecies.org/aphia.php?p=taxdetails\&id=382214 on 2016-08-16.

Cather, J. N. 1973. Regulation of apical cilia development by the polar lobe of Ilyanassa (Gastropoda: Nassariidae). Malacologia, 12(2): 213.

Cernohorsky, W. O., 1984. Systematics of the family Nassariidae (Mollusca: Gastropoda). Bull. Auckl. Inst. Mus. 14, 1-356.

Couto, D. R., Bouchet, P., Kantor, Y. I., Simone, L. R., \& Giribet, G. 2016. A multilocus molecular phylogeny of Fasciolariidae (Neogastropoda: Buccinoidea). Molecular phylogenetics and evolution, 99, 309-322. 
Cunha, R. L., Grande, C., Zardoya, R., 2009. Neogastropod phylogenetic relationships based on entire mitochondrial genomes. BMC Evol. Biol. 9, 1-16.

D'Asaro, C. N. 1993. Gunnar Thorson's world-wide collection of prosobranch egg capsules: Nassariidae. Ophelia, 38(3), 149-215.

De Pinna, M. G. G. 1991. Concepts and tests of homology in the cladistic paradigm. Cladistics 7: 367-394.

Diver, C. 1939. A method of determining the number of the whorls of a Shell and its application to Cepaea hortensis Müll. and C. nemoralis L. Proceedings of the Malacological Society 19: 234-239.

Fretter, V. \& Graham, A. 1962. British prosobranch molluscs, their functional anatomy and ecology. Ray Society, London. $\mathrm{i}^{-} \mathrm{xvi}+755 \mathrm{p}$.

Galindo, L. A., Puillandre, N., Utge, J., Lozouet, P., Bouchet, P., 2016. The phylogeny and systematics of the Nassariidae revisited (Gastropoda, Buccinoidea). Molecular Phylogenetics and Evolution. In press.

Gili, C., Martinell, J., 1994. Relationship between species longevity and larval ecology in nassariid gastropods. Lethaia 27: 291-299.

Golikov A. N., Starobogatov Y.I.. 1975. Systematics of prosobranch gastropods. Malacologia 15(1): 185-232.

Graham, A. 1985. Evolution within the Gastropoda: Prosobranchia. In: Trueman, E.R. \& Clarke, M.R. (Eds.). The Mollusca. v. 10. Evolution. Academic Press, London. p. $151-186$.

Haasl, D. M., 2000. Phylogenetic relationships among nassariid gastropods. $J$. Paleontol. 74, 839-852.

Harasewych, M. G. 1998. Infraorder Neogastropoda, p. 819-845. In: P. L. Ross Beesley (Ed.). 1998. Mollusca the Southern Synthesis, Vol. 5, Part. B. Csiro Publishing, $669 \mathrm{p}$.

Haszprunar G. 1988a. On the origin and evolution of major gastropod groups, with special reference to the Streptoneura (Mollusca). Journal of Molluscan Studies 54: $367-441$.

Hayashi, S., 2005. The molecular phylogeny of the Buccinidae (Caenogastropoda: Neogastropoda) as inferred from the complete mitochondrial 16S rRNA gene sequences of selected representatives. Molluscan Res. 25, 85-98. 
ICZN. 1999. International Code of Zoological Nomenclature. London (Inglaterra): International Trust for Zoological Nomeclature.

Jenner, M. G. 1979. Pseudohermaphroditism in Ilyanassa obsoleta (Mollusca: Neogastropoda). Science, 205(4413), 1407-1409.

Kaicher, S. D. 1973. Card catalogue of world-wide shells.

Kantor, Y. I. 1996. Phylogeny and relationships of Neogastropoda, pp. 221-230. In: Taylor, J.D. (Ed.). Origin and evolutionary radiation of the Mollusca. Oxford University Press, Oxford. 392 p.

Kantor, Y.I. 2002. Morphological prerequisites for understanding neogastropod phylogeny. Bollettino Malacologico, 38 (suppl. 4):161-174.

Kantor, Y. I., 2003. Comparative anatomy of the stomach of Buccinoidea (Neogastropoda). J. Molluscan Stud. 69, 203-220.

Kantor, Y. I., Kilburn, R.B., 2001. Rediscovery of Canidia dorri Wattebled, 1886, with discussion of its systematic position (Gastropoda: Neogastropoda: Nassariidae: Nassodonta). Nautilus 115, 99-104.

Kohn, A. J. 1959. The ecology of Conus Hawaii. Ecological Monographs 29:4790.

Lahbib, Y., Abidli, S., Chiffoleau, F.J., Averty, B., El Menifa, T.N., 2010. Imposex and butyltin concentrations in snails from the lagoon of Bizerta (Northern Tunisia). Mar. Biol. Res. 6, 600-607.

Landau, B. M., Harzhauser, M., Islamoglu, Y., da Silva, C.M., 2013. Systematics and palaeobiogeography of the gastropods of the middle Miocene (Serravallian) Karaman Basin, Turkey. Cainozoic Res. 11-13, 1-584.

Milne-Edwards H. 1848. Note sur la classification naturelle chez Mollusques Gasteropodes. Annales des Sciences Naturalles, series 3, 9: 102-112.

Nekhaev, I. O., 2014. Marine shell-bearing Gastropoda of Murman (Barents Sea): an annotated check-list. Ruthenica 24.

Nuttall, C. P., \& Cooper, J. 1973. A review of some English Palaeogene Nassariidae, formerly referred to Cominella. British Museum (Natural History).

Page, R. D. 1998. GeneTree: comparing gene and species phylogenies using reconciled trees. Bioinformatics, 14(9), 819-820.

Panchen, A. L. 1994. Richard Owen and the concept of homology: The Hierarchical Basis of Comparative Biology. San Diego, CA: Academic Press, 1994, 21-62. 
Ponder, W. F. 1973. The origin and evolution of Neogastropoda. Malacologia 12: $295-338$.

Ponder W. F, Lindberg DR. 1995. Gastropod phylogeny — challenges for the 90's. In: Taylor JD, ed. Origin and evolutionary radiation of the Mollusca. Oxford: Oxford University Press.

Ponder, W.F. \& Lindberg, D.R. 1997. Towards a phylogeny of gastropod molluscs: an analysis using morphological characters. Zoological Journal of the Linnean Society, 119:83-265.

Rios, E. C. 2009. Compendium of brazilian sea shells, 3 ed. Rio Grande. Evangraf, $676 \mathrm{p}$.

Sereno, P. C. 2007. Logical basis for morphological characters in phylogenetics. Cladistics 23: 565-587.

Shuto, T., 1969. Neogene gastropods from Panay Island, the Philippines. Contrib. Geol. Palaeontol. Southeast Asia LXVIII, 1-250.

Simone, L. R. L. 2005. Comparative morphological study of representatives of the three families of Stromboidea and the Xenophoroidea (Mollusca, Caenogastropoda), with an assessment of their phylogeny. Arquivos de Zoologia 37 (2): 141-267.

Simone, L. R. L., 2011. Phylogeny of the Caenogastropoda (Mollusca), based on comparative morphology. Arquivos de Zoologia 42: 83-323.

Simone, L. R. L., Cavallari, D. C., Abbate, D., 2013. Revison of the genus Teralatirus in the Western Atlantic, with an anatomical description of $T$. roboreus (Gastropoda: Neogastropoda: Fasciolariidae). Arch. Molluskenkunde 142 (2): 215-226.

Simone, L. R. L., Pastorino, G., 2014. Comparative morphology of Dorsanum miran and Bullia granulosa from Morocco (Mollusca: Caenogastropoda: Nassariidae). Afr. Invertebr. 55, 125-142.

Strong, E. E., 2003. Refining molluscan characters: morphology, character coding and a phylogeny of the Caenogastropoda. Zoological Journal of the Linnean Society, 137:447-554.

Thiele J. 1929. Handbuch der Systematischen Weichtierkunde. Vol. 1. Jena.

Troschel, F. H, (Thiele J). 1856-1893. Das Gebiss der Schnecken, zur Begr"undung einer nat"urlichen Classification. Berlin. 2 vols.

Vokes, E. H., 1969. The genus Trajana (Mollusca: Gastropoda) in the New World. Tulane Stud. Geol. Paleontol. 7, 75-83. 
Worms, 2015. Accessed through: World Register of Marine Species [WWW Document]. URL <http://www.marinespecies.org/aphia.php?p=taxdetails\&id=151>.

Zou, S., Li, Q., Kong, L., 2012. Monophyly, distance and character-based multigene barcoding reveal extraordinary cryptic diversity in Nassarius: a complex and dangerous community. Plos One 7, e47276. 


\section{Anexos}

Artigos publicados contendo as descrições de: Teralatirus roboreus, Pugilina tupiniquim e Bullia laevissima. 
